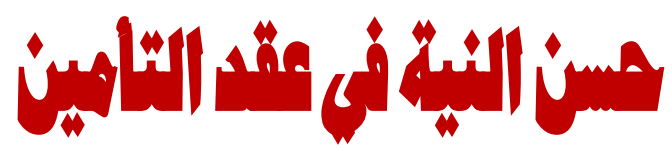 د د ياسـر محمد النيداني مدرس القانون المدني معهد العجمي العالي للعلوم الإدارية
}

\section{موجز البحث:}

موضوع هذا البحث يدور حول حسن النية في عقد التأمين ، وحيث أن عقد التأمين من ضمن العقود النموذجية التي تتسم بعدم التوازن الواضح بين طرفي عقد التأمين باعتباره عقدا قائما بين مهني محترف ، و مستهلك لا يعرف شيئا عن صناعة التأمين ، وحيث أن العقود يجب أن تتميز بحسن النية ، إلا أن حسن النية في عقد التأمين يتميز عن سائر العقود الأخرى التي تقوم على حسن النية دون تشديد لهذا الالتزام في حين أن حسن النية في عقد التأمين يجب أن يكون مطلقا. فيعد حسن النية من المبادئ القانونية ذات المصدر الأخلاقي بل ويعد في طليعتها والذى يعد جوهر العلاقات الاقتصادية والقانونية ويندر ألا نلتمس وجوده نصا

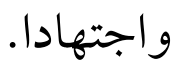

وعلى الرغم من أن مبدأ حسن النية يعتبر مكونا حيويا في مختلف مجالات القانون في معظم النظم القانونية حول العالم ، إلا أنه لا يوجد بين الدول التي تعترف به ما يشكل بالضبط جوهره وحدوده الأساسية ، كما أنه يبدو من الصعب إعطاؤه معنى دقيقا. إذا كان حسن النية يهدف بشكل عام إلى حماية الطرف الضعيف ، كون ذلك مطلب قوى في كل عقود الاذعان ، إلا أن له أهمية متزايدة وخاصة في عقد التأمين ، فهو أمر مفترض دائما ويحتاج إلى دليل على عدم وجوده من الطرف الذى يزعم ذلك ، كما أنه 
التزام متبادل ، حيث يتطلب حسن نية كل من المؤمن والمؤمن له ، حيث يعتمد المؤمن وبشكل قوى على تصريحات شريكه المتعاقد معه وذلك لتقييم المخاطر التي يتحملها وبالتالي يجب أن تكون هذه التصريحات صادقة كذلك يجب أن يكون المؤمن حسن

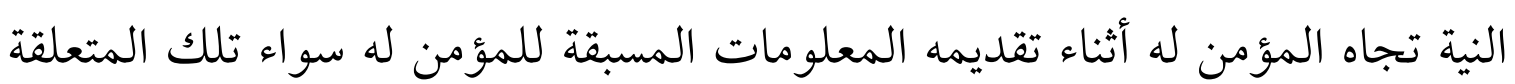
باسمه التجاري وقدراته وإمكاناته في مجال التغطية ، وهذه المعلومات يعتمد عليها طالب التأمين باعتبار أن شركة التأمين في أغلب الأحيان تكون الهصدر الوحيد

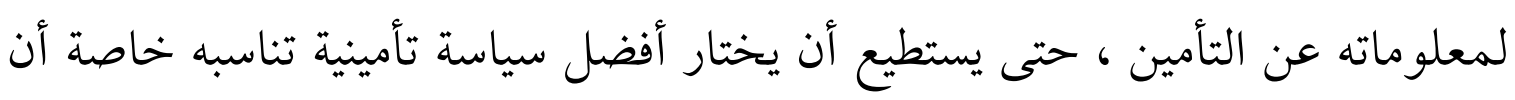
حرمانه من المعلومات السابقة على التعاقد تعمل على اختلال التوازن العقدي .

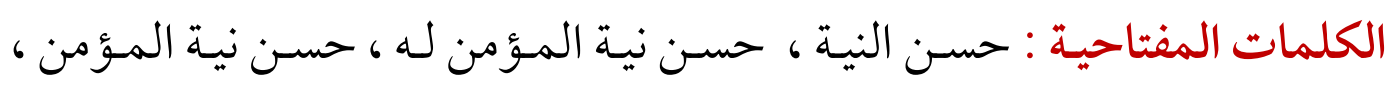

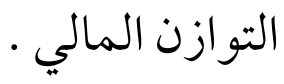




\title{
Good Faith In The Insurance Contract
}

\author{
Yaser Mohamad Elnaydany \\ Civil Law , Al- Ajami Higher Institute For Administrative Science. \\ Email : dr.yaser.moh@gmail.com
}

\begin{abstract}
Absract :
The subject of this research revolves around Good faith in the insurance contract, and that the insurance contract is among the model contracts that are characterized by a clear imbalance between the two parties to the insurance contract as a contract between a professional and a consumer who does not know anything about the insurance industry, and where the contracts must be distinguished by good Intention, however, the Good faith in the insurance contract is distinguished from all other contracts that are based on Good faith without an emphasis on this obligation while the Good faith in the insurance contract must be absolute.

Good faith is one of the legal principles of moral origin, and it is even the forefront, which is the essence of economic and legal relations, and it is rare that we do not seek its existence by text and diligence.

Although the principle of good faith is a vital component in various areas of law in most legal systems around the world, there is no among the countries that recognize it as what constitutes its very essence and essential limits, and it seems difficult to give it an accurate meaning

If Good faith generally aims to protect the weak party, as this is a strong requirement in all compliance contracts, except that it has increasing importance, especially in the insurance contract, it is always assumed and needs evidence of its absence from the party that claims this, as it is an obligation Mutual, where the Good faith of both the insured and the insured is required, as the insured relies strongly on the statements of his contracted partner in order to assess the risks he incurs and therefore these statements must be true as well. The insurer must be well-intentioned towards the insured during the provision of advance information to the insured Whether those related to his commercial name, capabilities, and capabilities in the field of coverage, and this information is relied upon by the insurance applicant, given that the insurance company is often the only source of his information about insurance, so that he can choose the best insurance policy that suits him, especially since depriving him of the previous information on the contract works to disrupt Nodal balance.
\end{abstract}

key words: Good faith, good faith for the insured, good faith for Insured, financial balance. 


\section{تمهيد}

يهدف القانون إلى تحقيق الأمن الاجتماعي واستقرار المعاملات ، في حين تهدف القواعد الأخلاقية إلى تحقيق الكمال الذاتي وراحة الضمير مقتصرة على الواجبات تجاه النفس والغير دون أن تولد حقا يقابل هذا الو اجب لصالح الآخر لأن غايتها مثالية"). و القانون لا يحقق هدفه المنشود دون تعميق مبادئ الخير في وجدان المجتمع لتساعده في ضبط سلوك الأفر اد. وبما أن العقود تعد أساس حركة الحياة الاجتماعية ، إذ بها يتم التبادل وتلبية الحاجات وحيث إن العلاقات العقدية في حقيقتها ليست تبادلا ماديا وإنما تبادل أخلاقي لتأمين منافع مادية تعود على الأفراد والمجتمع بالخير وتحميه من الفساد وبالنظر إلى أن مبرر وجود العقد أخلاقي (r) فعلى هذا الأساس استندت معظم القوانين الحديثة في توجهاتها على قيم الخير و التصدي لقيم الشر ، فنجد أغلب القواعد القانونية هي في الوقت ذاته قواعد خلقية(() ؛ حيث اتجهت أغلب الأنظمة القانونية لحماية أخلاقيات التعاقد في التعامل بين أطر اف العقد حماية لتطلعاتهم المشروعة نحو إقرار قواعد الأخلاق وجعلها أساسا لتصرفات الأشخاص وأعمالهم. وبهذا الإقرار لهذه القيم والمبادئ الأخلاقية لم تعد هذه القيم مبادئ نصح وإرشاد ، بل

(1) فاطمة الزهراء زيتوني ، مبدأ حسن النية في العقود ، رسالة دكتوراه ، كلية الحقوق و العلوم السياسية جامعة أبى

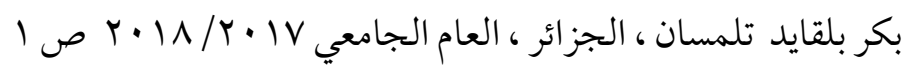

(Y) سماح جبار ، القيمة القانونية للعنصر الأخلاقي في العقود الخاصة ، رسالة دكتوراه ، كلية الحقوق والعلوم

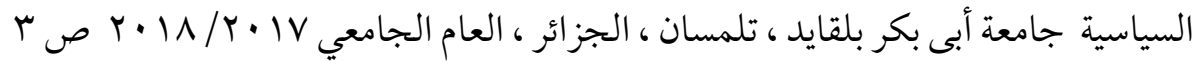

(r) هدى بن أئوب ، مبدأ حسن النية في العقود ، رسالة ماجستير ، جامعة العربي بن مهيدى أم البواقي الجزائر ،

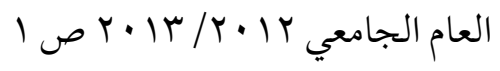


أصبحت حقائقا يتوقف عليها سلامة المعاملات بين الأفراد باعتبارها وسيلة لتحقيق العدل الذى يمثله غاية القانون(1).

ومن بين أهم المبادئ القانونية ذات المصدر الأخلاقي بل ويعد في طليعتها مبدأ حسن النية

في العقود الذى يعد جوهر العلاقات الاقتصادية والقانونية ، ويندر ألا نلتمس وجوده نصا واجتهادا.

وفقا للعميد ريبير فإن حسن النية إحدى الوسائل التي استخدمها المشرع لإدخال القاعدة الأخلاقية إلى المجال القانوني"(). فهو طريق من عدة طرق للتوفيق بين الأخلاق والقانون(r). فهذا المبدأ له دور هام في العلاقات العقدية سو اء في مرحلة التفاوض أو عند إبرام العقد أو عند تنفيذه ، حيث أشار إليه المشرع المصري من خلال نص المادة ^ع ا من القانون المدني المصري ، وكذا المشرع الفرنسي من خلال نص المادة ع • 11 من القانون المدني الفرنسي . والغرض من حسن النية في العقود هو تنظيم معايير الأخلاق من أجل خلق التوازن الصحيح بين اليقين التجاري والحد من السلوك غير الأخلاقي (2). ولما كانت العقود مما لا يستغنى عنها أحد ، ولأن نظرية العقد تطورت مع تطور الحياة الاقتصادية عبر الحقب الماضية بفعل التغيرات السياسية والاقتصادية وحتى الخلقية التي أحاطت بها ، فقد تطور تبعا لذلك دور مبدأ حسن النية.0.

وحيث إن موضوع هذا البحث يدور حول حسن النية في عقد التأمين ، وحيث إن عقد

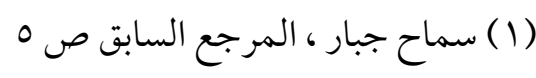

(2) GEORGER Ripert .La regle morale dans les obligations civiles,4 ème ,ed LGDJ. Paris, 1949 , p.31

(3) Yiqing Yang, The Past and Future of Utmost Good Faith: A Comparative Study Between English and Chinese Insurance Law Submitted, a thesis for the degree of Doctor, University of Exeter, December 2017 ,p88

(4) Yiqing Yang , op , cit ,p.87

$$
\text { (0) فاطمة الزهر اء زيتوني ، المرجع السابق ص ع }
$$


التأمين من ضمن العقود النموذجية التي تتسم بعدم التوازن الواضح بين طرفي عقد التأمين

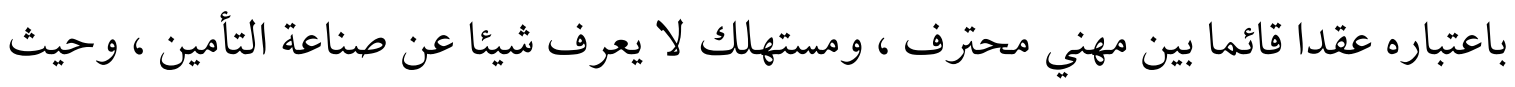
إن العقود يجب أن تتميز بحسن النية ، إلا أن حسن النية في عقد التأمين يتميز عن سائر العقود

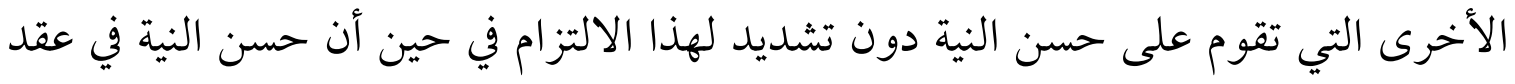
التأمين يجب أن يكون مطلقا. إن مصطلح مفهوم حسن النية يستخدم دائما من قبل المشرع للتخفيف من قسوة وصرامة بعض النصوص القانونية التي قد يؤدى تطبيقها إلى ما يخالف روح العدالة وجوهره "(1).

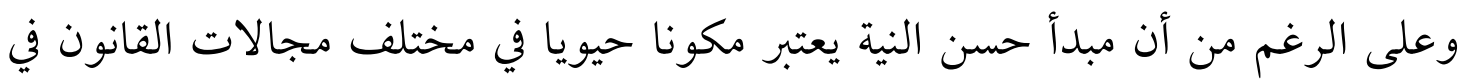
معظم النظم القانونية حول العالم ، إلا أنه لا يوجد بين الدول التي تعترف به ما يشكل بالضبط جوهره وحدوده الأساسية ، كما أنه يبدو من الصعب إعطاؤه معنى دقيقا"). فلم يعرف المشرع المصري أو المشرع الفرنسي حسن النية ، وقد تصدى الفقه لتعريف

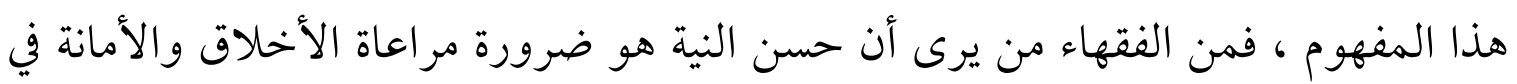

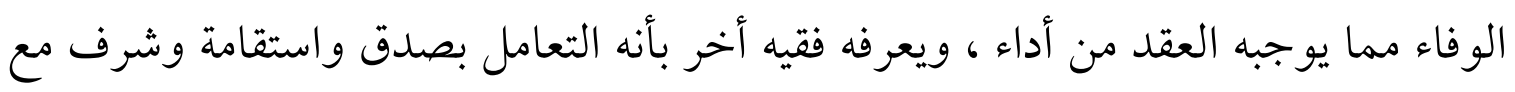

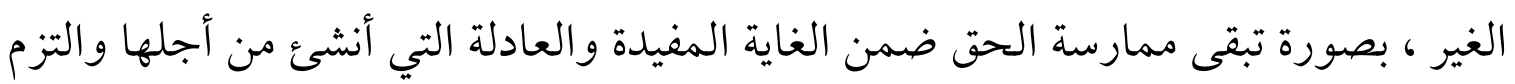

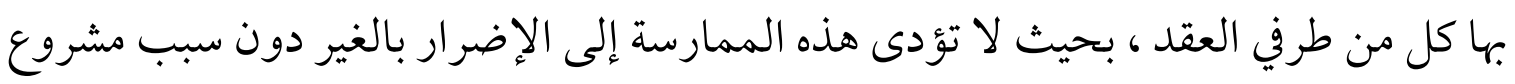
بل توصل كل ذي حق حقه بأمانة ، ومن الفقهاء من يرى أن حسن النية هو الجهل المبرر

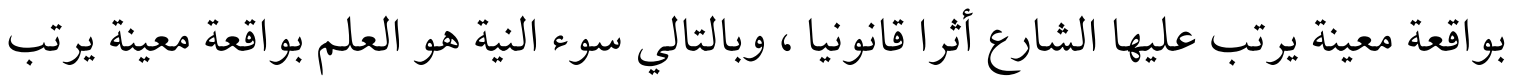

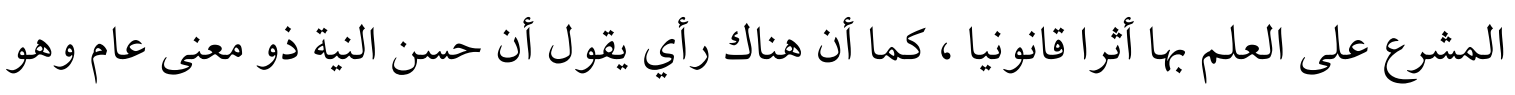

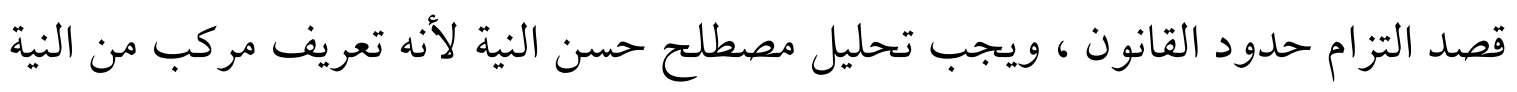

(1) GATSI (J), Nouveau dictionnaire juridique, Presses Universitaires Libres 2ème édition, 2010, p. 52.

(2) Yiqing Yang, op , cit , p.83 
التي هي القصد وعزم القلب على شيء معين ، والحسن و السوء عبارة عن أحكام اجتماعية ترتبط بالقيم السائدة في المجتمع ، كما أن البعض قرر بأن حسن النية هو أن تحترم ما قام بينك وبين الطرف الأخر من أوضاع وأن تنفذها وفقا لذلك وليس كما تريد . وهناك من ينظر إلى حسن النية من منظور عكسي ؛ فحسن النية هو مفهوم خاص يقوم على أساس استبعاد سوء النية ، وقد عرفه البعض بأنه الإخلاص والأمانة فيما يقصد المتعاقدان وفيما يهدفان إليه من وراء العملية التعاقدية'). أيا ما كان الأمر فإنه لا يوجد اتفاق على تعريف حسن النية ، كما يوجد صعوبة في إعطاء معنى دقيق وإيجابي لا لبس فيه ، والواقع أن جماع التعريفات السابقة تدور حول كل المشاعر الصادقة لضمير صالح ، ويعبر عنها بالمفاهيم التالية: الإنصاف ، السلوك العادل ، المعايير المعقولة للتعامل العادل ، السلوك اللائق ، الحس الأخلاقي ، روح التضامن والتعاون معايير الإنصاف المجتمعية ، الصدق في الواقع ، وغيرها من المفاهيم التي تدل على الصدق والنزاهة في التعاقد وتوقع أي طرف من أطراف التعاقد أن يقوم الطرف الآخر بأداء واجباته بصدق ونز اهة بموجب العقد بطريقة مقبولة) م(1). فحسن النية كسلوك عادل يجعل من الممكن أن يطلب من أي طرف من أطراف العقد الإخلاص الحقيقي والولاء في القيام بالواجبات التي تقع على عاتقه ، ولذلك فإن المتعاقد يتمتع بحسن نية إذا قام بإخلاص بتنفيذ التزاماته حتى لا تحدث أخطاء إلا عن غير قصد ، وعلى أن يتمتع بحماية خاصة بسبب تخفيف شدة العقوبة ضده (r)، كما أن القاضي يتخذ من حسن النية وسيلة لتحديد ما إذا كان سلوك أحد طرفي العقد يتماشى مع سلوك

$$
\text { (1) راجع في تفاصيل تعريف حسن النية ـ هدى بن أيوب ، المرجع السابق ص •r-0 ع }
$$

(2) Yiqing Yang, op , cit , p.88

(3) Henriette E. Kameni, La bonne foi dans le contrat d'assurance Université de Douala . Master II Recherche 2008 ,p. 3 


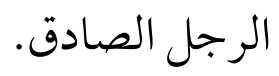

إذا كان حسن النية يهدف بشكل عام إلى حماية الطرف الضعيف ، كون ذلك مطلب قوى

في كل عقود الإذعان ، إلا أن له أهمية متز ايدة وخاصة في عقد التأمين ، فهو أمر مفترض دائما

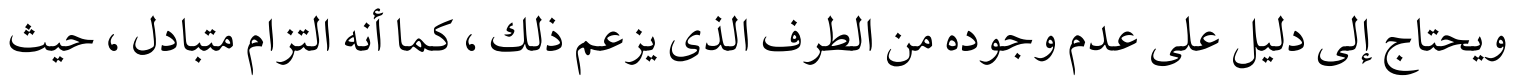
يتطلب حسن نية كل من المؤمن والمؤمن له ، حيث يعتمد المؤمن وبشكل قوى على

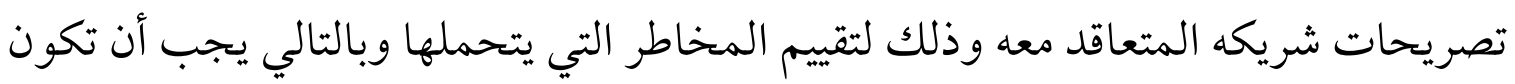
هذه التصريحات صادقة كذلك يجب أن يكون المؤمن حسن النية تجاه المؤمن له أثناء تقديمه المعلومات المسبقة للمؤمن له سواء تلك المتعلقة باسمه التجاري وقدراته وإمكاناته في مجال التغطية ، وهذه المعلومات يعتمد عليها طالب التأمين باعتبار أن شركة التأمين في أغلب الأحيان تكون المصدر الوحيد لمعلوماته عن التأمين ، حتى يستطيع أن يختار أفضل

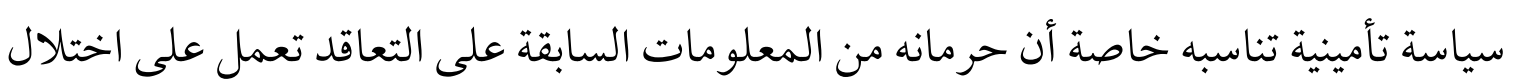

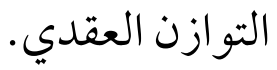

ونظر الأهمية عقد التأمين كأحد أهم المعاملات في عصرنا الحالي ، ونظر اللدور الخاص الذى يقوم به حسن النية في هذا العقد في جميع مراحله بداية من مرحلة التفاوض ، مرورا بإبر ام العقد ، ووصو لا إلى تنفيذه ، فقد كان سبب اختياري للبحث في هذا الموضوع .

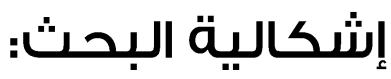

ومن هذا المنطلق فإن إثكالية بحثنا يمكن طرحها كما يلى: ما هو أثر حسن النية على كل

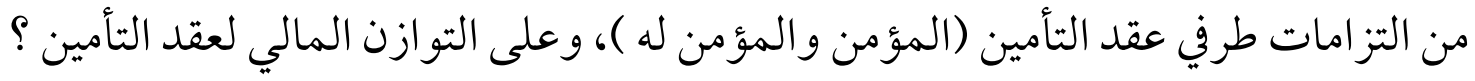

\section{منهج البحث:}

وقد اعتمدنا في دراستنا على المنهج التحليلي الوصفي إضافة إلى المنهج المقارن، وذلك بوصف وتحليل أثر حسن النية في التزامات المؤمن والتزامات المؤمن له، وأثرها على إلى التوازن المالي لعقد التأمين منذ بداية التفاوض عليه وحتى انهاؤه من جهة ، ومن جهة أخرى 
المقارنة بين القانونيين المصري والفرنسي وما ورد فيهما من أحكام تتعلق بهذا الموضوع.

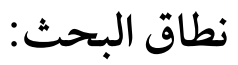

سيقوم الباحث في هذا البحث بطرح مسائله المتعلقة بموضوع التأمين من خلال القانونين

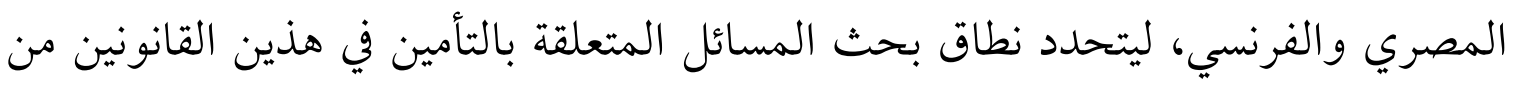
خلال دراسة تحليلية مقارنة"). وعلى ذلك وبناء عليه وطبقا لهذا المنهج وللوصول للإجابة على اشكالية البحث بشكل علمي، فإنه سيتم التطرق إلى تناول هذا الموضوع في ثلاثة مباحث على النحو التالي :

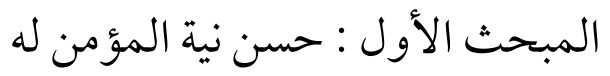
المبحث الثاني : حسن نية المؤمن المبحث الثالث : حسن نية المؤمن كوسيلة للحفاظ على التوازن المالي لعقد التأمين

(1) كما سيتم التطرق في بعض النقاط إلى قوانين بعض البلدان العربية ، وكذلك قانون التأمين لبلدان غرب افريقيا الناطقة باللغة الفرنسية المعروف بقانون CIMA. 


\section{المبحمث الأول

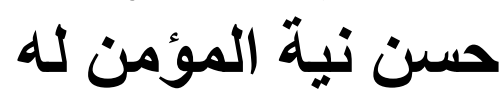

سوف نستعرض حسن نية المؤمن له في مرحلة المفاوضات التعاقدية وفي مرحلة تنفيذ عقد التأمين في مطلبين متتاليين على النحو التالي :

\section{المطلب الأول \\ حسن نية المؤمنن له في مـرحلة المغاوضات}

يعد التزام المؤمن له بالإدلاء بالمعلومات هو الالتزام الأساسي للمؤمن له في مرحلة المفاوضات حيث إنه لا وجود لعقد تأمين بدون معلومات ، هذه المعلومات مهمة جدا ولها أهمية بالغة حيث تعتمد عليها شركة التأمين في تقييم المخاطر وتحديد قبول إبرام عقد التأمين من عدمه كما يعتمد عليها صحة عقد التأمين إذا تم إبرامه ، كما أنها تعتبر الخطوة الأولى للتطبيق الفعلي لحسن نية المؤمن له بعقد التأمين فيجب أن يكون المؤمن له حسن النية في أدائه التزامه بالإدلاء بالمعلو مات حيث إن حسن النية مفترض في عقد التأمين. ونظر اللأهمية البالغة للمعلومات باعتبارها اللبنة الأولى في عقد التأمين ، فإن المشرع قد اهتم بها ، وركز على حسن نية المؤمن له في أدائه هذا الالتزام في هذه المرحلة . وسوف نتناول في هذا المطلب على التوالي التزام المعلومات، شكل إعلان المؤمن له للبيانات المطلوبة منه ، إشكالية الأسئلة التي لم يضعها المؤمن ، ومدى التزام المؤمن له بالإعلان عن الظروف التي تجد في الفترة بين الإعلان الأولى وإبرام عقد التأمين ، والمسائل التي لا يلزم الكشف عنها ، ومدى التزام المؤمن له بالتعاون لتنفيذ إعلان المخاطر والعقوبات على المؤمن له في حال الإدلاء بالبيانات الخاطئة وذلك في الفقرات التالية :

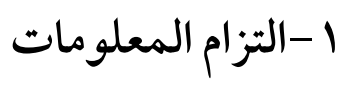
يلتزم طالب التأمين في مرحلة المفاوضات بأن يقدم للمؤمن بيانات كاملة وصحيحة عن 
الخطر المزمع التأمين منه(1)وهذا الالتزام يعتبر من الالتزامات الأساسية التي يفرضها عقد التأمين(r)على عاتق كل طالبي التأمين بلا استثناء(r) يعطى للمؤمن له إشعار معلومات بشأن العقد يصف فيه الضمانات مع الاستثناءات. فيعد إعلان المؤمن له للبيانات المتعلقة بالخطر والظروف المحيطة به بيانا جوهريا وضروريا ؛ لأنه من غير المتصور أن توافق شركة التأمين على ضمان خطر بدون معلومات لذا إعلان المخاطر سيسمح للمؤمن بتكوين فكرة حقيقية ودقيقة عن الخطر المؤمن منه (8) وبتصنيف فئات المخاطر وسرد خصائصها ، وسيسمح له بأن يعرف ما إذا كان سيقبل التأمين أم لا (o)، في حال قبوله سيحدد بناء عليه قسط التأمين الذى يقابل الخطر ، كما أنه سيسمح للمؤمن له بالقدرة على تحديد الخطوط العريضة لتأمينه المستقبلي ومعرفة أقساطه وفقا لإجاباته التي قدمها. فلبيان المعلومات المتعلقة بالمخاطر أهمية كبيرة ، لذا ينبغي إيلاء أكبر قدر من الاهتمام د.محمد حسام لطفي، الأحكام العامة لعقد التأمين ، دراسة مقارنة بين القانونين المصري و الفرنسي القاهرة

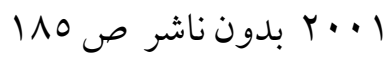

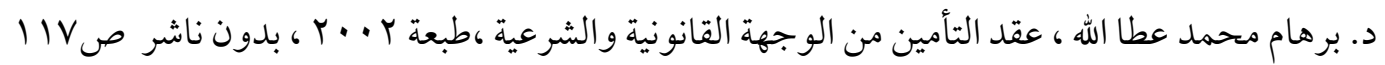
(r) -فيعتبر التزام المؤمن له بالإدلاء بالبيانات للمؤمن تجسيدا لمقتضيات النزاهة وحسن النية فنظير التزام

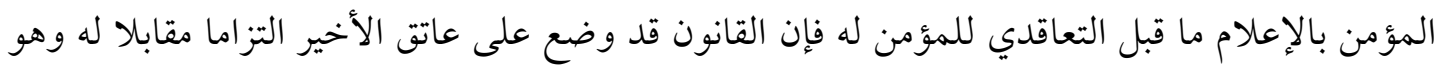

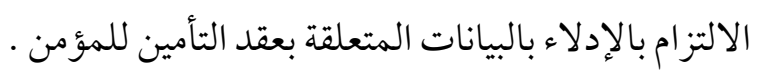
حسن حدون ، التكافل العقدي، رسالة ماجستير ،جامعة الجزائر 1 بن يوسف بن خدة ، كلية الحقوق سعيد

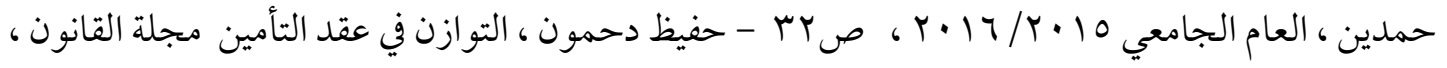

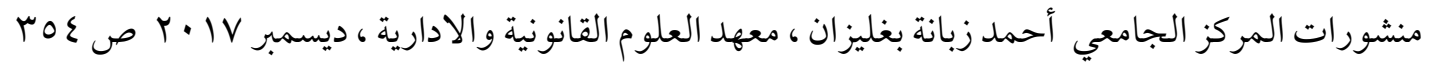

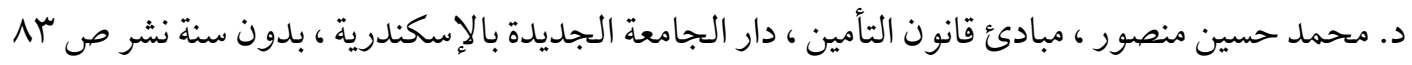

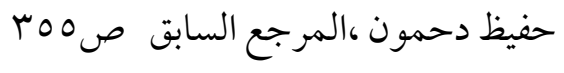


به ؛ وذلك لأنه سيدخل المؤمن له لأول مرة في المرحلة الأولى من الشفافية خلال الفترة قبل التعاقدية وخلال هذه الفترة سيثت المؤمن له صدقه في علاقاته التعاقدية التي تكمن في التزامه بالإعلان عن المخاطر ، ومن ناحية ثانية فإن دقة هذا الإعلان هي الشرط الضروري لاستمرار العلاقة التعاقدية ؛ لذلك يجب على المؤمن له أن يدلى بهذه البيانات بمنتهي الدقة والصدق"(1)وهذا هو المقصود من وصف عقد التأمين بأنه من عقود منتهي حسن النية . فشرط حسن نية المؤمن له في الإدلاء بالبيانات المتعلقة بالخطر قبل التعاقد يكون ساري المفعول ويتضح ذلك من حيث الواقع"حيث نجد أنه منصوص عليه بعبارات واضحة وصريحة تهدف إلى الدقة الملحة لتصريحات وإعلانات المؤمن له وذلك في المادة 10 من مشروع وزارة الاقتصاد( المقابلة للمادة 77 + 1 من المشروع التمهيدي للتقنين المدني الحالي ) و التي يقابلها نص المادة r I / / Y من قانون التأمين الفرنسي.

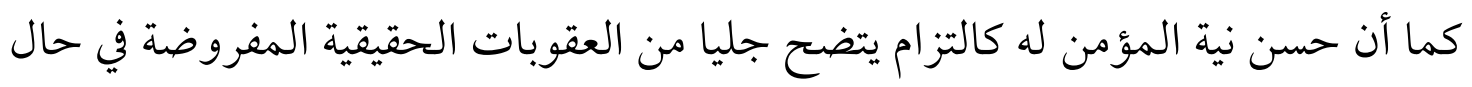
عدم الامتثال له والإدلاء بالبيانات بسوء نية)(ب). ب - شكل إعلان المؤمن له للبيانات المتعلقة بالخطر لقد مر شكل إعلان المؤمن له عن المخاطر بمرحلتين هما : المرحلة الأولى مرحلة الإعلان التلقائي ، المرحلة الثانية تم تعديل شكل الإعلان مع ابتكار أسلوب الاستبيان.

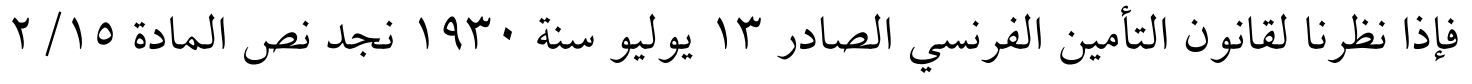
كان يتبنى فكرة الإعلان التلقائي ؛ وذلك يعنى أن طالب التأمين كان ملتزما بالإعلان عن جميع الظروف المعروفة له والتي لها طبيعة التأثير الأهم على شركة التأمين في تحديد وتقييم

(1) برهام عطا الله ، المرجع السابق ، صVVV

(2) Henriette E. Kameni, op, cit, p.15

(3) Ibid,p.15 et 19 
المخاطر (1)وتحديد القسط الواجب دفعه وفي قرار قبولها للتأمين على هذه المخاطر من عدمهd)

فهذا النص صنع ما يسمى الإعلان التلقائي وأصبح المؤمن له ملتزما التزاما إيجابيا بإبلاغ شركة التأمين بالحقائق ذات الصلة بالخطر (r)فإذا كان المؤمن له شخصا مختلفا عن طالب التأمين فإن المؤمن يطلب منه كذلك مثل هذا الإعلان. وبما أن طالب التأمين هو صاحب المبادرة في طلب التأمين فإنه سيصبح مسئولا بالتالي عن إعلانه حيث إن الخطأ يفسد كل شيء.

هذا النظام كان يبدو نظاما بسيطا لكنه في الحقيقة كان قابلا للانتقاد ؛ وذلك لأن شرط حسن النية الممتد جعل شركات التأمين تعتمد موقفا سلبيا باعتمادها كليا على المعلومات المقدمة من المؤمن له صاحب الاقتراح ، ويالتالي لم يكن لديها التزام بالتحقق من أقواله ، كما أثقلت عليه كمحترف يحق له إبداء أية استفسارات بخصوص عقد التأمين ، في حين أن المؤمن له في جميع الحالات تقريبا لم يكن لديه القدرة على تخيل كل الظروف ذات الصلة بالخطر المؤمن ضده ، كما أنه لم يكن ليستطيع أن يحدد من بين الظروف المعروفة له ، تلك التي تؤثر بالفعل على رأي المؤمن (s)فقد يعلن معلومات عديمة الفائدة ، وقد ينسى معلومات مفيدة كما أنه ليس محاميا أو متخصصا في التأمين ، فيمكن للمؤمن له أن يكون على دراية بالمعلومة ومع ذلك لا يمكن له دائما معرفة مدى تو افقها مع الخطر موضوع التعاقد ، لذلك لا تستطيع إلقاء اللوم على المؤمن له بسبب عدم دقة إعلانه (o).

(1) -PATRICE FIL . L'obligation d'information et de conseil en matière d'assurance, presses universitaires d'Aix-Marseille, 1996, p.82

(2) M. B. CRESCENZO-D'AURIAC, Devoir d'information et de conseil en matière d'assurance, J- Cl., Civ., Fasc. 6, 2005, p.82

(3) Christianne Dubreuil , L'assurance: un contrat de bonne foi A 1'6tape de la formation et de l'ex cution, McGill Law Journal 1992,p.1091

(4) J. KULLMANN et al. Lamy assurances, Paris, 2008, p. 144

(5) Cass. 1 re civ. 6 janv. 1994, n 91-20.095, n³0, RGAT, 1994, p.474, note F. CHARDIN 
كثير اما كان يكتشف أن المؤمن له لم يدل بالمعلومات الهامة التي تهم المؤمن بالتالي كان يمكن لشركة التأمين أن تطلب في أي وقت إنهاء العقد بسبب عيب الموافقة بناءا على احتفاظ المؤمن له بالمعلومات ، وقد كان كافيا أمام التطبيق الصارم من المحاكم لفكرة الإعلان العفوى أن تثبت شركة التأمين أن المؤمن له كان على علم بالظروف المعنية بالمخاطر وبإثبات تأثير ها على تقييم هذه المخاطر (1).

وأمام هذا النقص في المعلومات التي كانت تؤدى من المؤمن له فقد أدانت لجنة الشروط التعسفية هذه العملية ، وأوصت بأن تقدم شركة التأمين بوصفها المحترف الحقيقي في عقد التأمين لكل عميل محتمل استبيانا يتضمن العديد من الأسئلة الدقيقة والواضحة حسب كل عملية تأمين (()، كما أن المؤمن شعر أن من واجبه كمحترف أن يقدم استفساراته للمؤمن له عن المعلومات المتعلقة بالخطر ، وأمام ممارسات شركات التأمين تخلى المشرع الفرنسي عن فكرة الإعلان التلقائي ، وقام المشرع بإصلاح النظام بغرض تصحيح عدم اليقين القانوني الناشئ عن النظام التلقائي ، من خلال النص على أن إعلانات المؤمن له تتم من خلال

$$
\text { أسلوب الاستبيان ( المادة Y | / / م من تقنين التأمين الفرنسي ). }
$$

مع أسلوب الاستبيان لم يعد كافيا أن نطلب من المؤمن له أن يعلن عن الظروف المتعلقة بالخطر ؛ وذلك لتنوير وتبصير المؤمن ، بل يجب عليه الإجابة بإخلاص وبصورة دقيقة(r)عن الأسئلة المطروحة عليه()و التي يجب أن تكون واضحة بما فيه الكفاية(1) لكى يستطيع المؤمن

(1) في أحد الأحكام أشارت محكمة النقض إلى أن الإعلان من المؤمن له يجب أن يكون عفويا لذلك أدانت

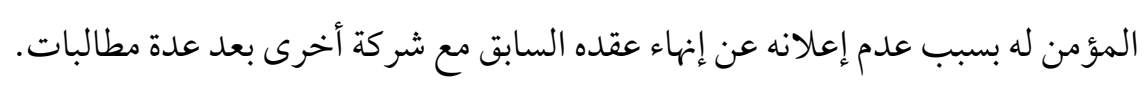

Cass,1rè ch. CIV/ 07/02/1990, RGDA, 1990, p. 313, note R. Maurice

(2) Recomm. N85-04, 20 sept. 1985 cité in V. Lamy assurances, 2008, op, cit , p. 41

(3) Civ. 2e, 16 déc. 2010, n 10-10.859 et 10-10.865, Bull. civ. II, $n^{\circ} 208$

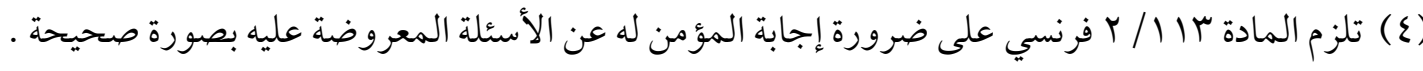


له الرد عليها.

الأمر أصبح متروكا لشركة التأمين بما لها من مهنية واحترافية لتحديد المعلومات التي

تراها ضرورية لتقييم المخاطر ، عن طريق استخدامها نموذجا فعالا للحد من إمكان الشكوى

من ممانعة المؤمن له ؛ فأصبح لديها المبادرة لطرح الأسئلة(1)التي يجب أن تقود المؤمن له للإعلان عن الظروف المعنية(م)التي يعرفها المؤمن له حيث لا يمكن مطالبته بالكشف عما لا يعرفه(s) غالبا ما تكون الأسئلة في شكل اختيار من متعدد ؛ للحصول من المؤمن له على إجابات أكثر وضوحا وأقل إرباكا كما أنها تحد من الخطأ.

مع أسلوب الاستبيان لم يعد هناك قلقا لدى المؤمن بشأن احتفاظ المؤمن له بالمعلومات هذا الأخير يجب عليه أن تكون إجاباته واضحة ومفهومة ومحددة وكاملة لا تترك أي شك ليكون بمأمن من أي عقوبة(0) وبالتالي لا يجب عليه ترك أسئلة بالاستبيان دون أن يرد عليها() أو الإدلاء بإجابات غامضة أو غير دقيقة ، كما يجب عليه عدم الكشط أو المحو في الاستبيان. الممارسة العملية"(v) جريت على قيام المؤمن بعمل نموذج أسئلة مطبوع (م)يضمنه كل ما يريد

16. p. 16 الأستاذ الدكتور أحمد شرف الدين ، أحكام الثأمين ، دراسة مقارنة في

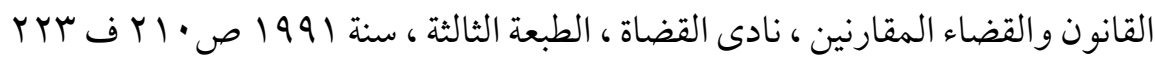

(1) Crim., 14 janv. 1998, RGDA 1998. 268, note J. Landel

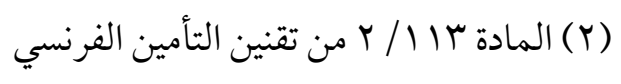

(3) Cass. 1re civ. 7 Juill. 1987, D. 1988, p. 158 - Civ. 2ème 15 fève. 2007, Bull. civ. II n 36

(4) Mme FABRE-MAHNAN, De l'obligation d'information dans les contrats. Essai d'une théorie : LGDJ $1992, N^{\circ} 244$

(5) PATRICE FIL. Op,cit , p.82

(7) فإذا كان البيان قد جعله المؤمن محل سؤال محدد ومكتوب أو تطلب من المؤمن له إثباته كتابة في طلب التأمين اعتبر جوهريا في نظره ولازما لتقدير الخطر المؤمن منه يترتب على الاخلال به أن يقع عقد التأمين

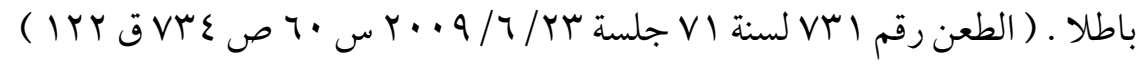

(7) Christianne Dubreuil, op , cit , p.1093

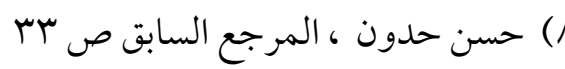


معرفته من بيانات مؤثرة في فكرته عن الخطر (1)وذلك إلى جانب البيانات المتعلقة بشخص المؤمن له ؛ وذلك حتى لا يدخل في دوامة إثبات تأثير البيان الذى لم يتصل بعلمه عن هذه

يجب أن تكون شركة التأمين مبدعة في إعداد أسئلة الاستبيان بحيث لا تكون قادرة على

طرح الأسئلة الصحيحة حول المخاطر فقط ، ولكن أيضًا من خلال توسيع أسئلتها إلى مناطق قد تبدو بعيدة كل البعد عن الخطر ، وليس لها علاقة مباشرة بالمخاطر المضمونة(r). المؤمن غالبا ما يضع الأسئلة-كما سبق القول - في شكل اختيار من متعدد وعليه أن يقوم بالتحقق من إجابات المؤمن له عليها بوضوح ، كذلك يمكن للمؤمن له أن يطلب من المؤمن معاونته في مل \& الاستبيان()وهذا التعاون يحد من الخطأ. غير أن المؤمن غير ملزم بصياغة أسئلته كتابة ، فيمكنه أن يسأل شفويا عن التفسيرات اللازمة ويسجل الإجابات التي قدمها المؤمن له حول هذا الموضوع في الشروط المحددة لعقد التأمين.

في الواقع يجب على المؤمن له الإجابة على جميع الأسئلة التي تظهر في الاستبيان نفسه أو رسالة ، فاكس ، إلخ ، أو حتى عندما يكون الطلب ببساطة شفهيًا (م). رغم الميزات العديدة للإدلاء بالبيانات عن طريق الاستبيان ، إلا أن هناك مشكلة أكثر

(1) د. عبدالرزاق أحمد السنهوري ، الوسيط في شرح القانون المدني ، الجزء السابع ، المجلد الثاني ، عقود الغرر ،

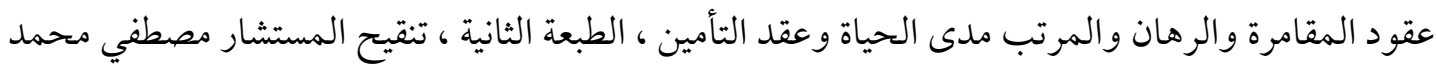

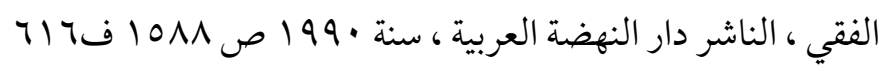

(2) Picard et André Besson, , Les assurances terrestres, t.1 "le contrat d'assurance" 5 ed, Paris , L.G.D.J., 1982 , p.129, no 74

(3) -Camila HABOUBI, Le secret en droit des assurances, Thèse Université Jean Moulin Lyon 3 , École doctorale : Droit ,2009, no 65

$$
\text { 119 - Henriette E. Kameni, op , cit ,p.17 ( ) }
$$

(5) Lamy assurances, 2008, op. Cit. p. 145. 


\section{أهمية وهي مشكلة البيانات التي لم يطلبها المؤمن في الاستبيان . r- إشكالية الأسئلة التي لم يطرحها المؤمن.}

المبدأ العام أن المؤمن له يجب أن يجيب فقط عن الأسئلة المطروحة عليه من قبل المؤمن فعليه أن يعلن عن الظروف المعروفة له والتي تتوافق مع الأسئلة التي يطرحها المؤمن، وفي حال غياب الأسئلة التي لم يضعها الأخير فلا يكون المؤمن له مسئولا عن الحقيقة غير المعلنة(1) بالتالي لا يلتزم بكتابة ما لم يرد بشأنه سؤالالا()وذلك بحكم عدم مهنيته واحتر افه وبالتالي قد لا يدرك تماما ما يهم المؤمن وما لا يهمه ، فبإجاباته على الأسئلة المطروحة فقط في الاستبيان يكون قد أوفي بما هو مطلوب منه(r). ومع ذلك فهناك رأي في الفقه يرى أن هناك امتداد لمبدأ حسن النية في عقد التأمين، وبالتالي فإن المؤمن له مطالب بالإضافة إلى الإجابة بدقة وأمانة عن الأسئلة التي طرحها عليه المؤمن في الاستبيان أن يقدم بشكل تلقائي كل شيء معروف له(8)عن الخطر المؤمن ضده ويكون له تأثير على تقييم المخاطر (o). ويذلك فإن المؤمن له سيكون سيء النية إذا كان محتجزا لبعض الحقائق عن الخطر مع معرفته بتأثير ذلك على تقييم المخاطر ، وفي هذه الفرضية الأخيرة فإن المؤمن له يكون قد ارتكب خطأ أثر على مو افقة المؤمن ، ويؤدى ذلك إلى بطلان عقد التأمين ويؤسس هذا الرأي على قاعدة أن الاحتيال يتحدى جميع قواعد القانون وبالتالي يتحدى القاعدة المتمثلة في أن الشخص المؤمن له مسئول فقط عن

(1)- Cass. Civ. II, 15 février 2007, $\mathrm{n}^{\circ}$ 05-20.865 et Cass. Civ. II, 7 février 2014, ${ }^{\circ}{ }^{12-85107}$

(2) Yvonne Lambert-Faivre, Droit des assurances, 10 éd., Paris, Dalloz, 1998, p228.no316

(3) Christianne Dubreuil, op , cit ,p.1093

$$
\text { ( ) فيجب على المؤمن له الإفصاح عن كل ظرف مادى معروف له }
$$

130 Yiqing Yang, op, cit , p.

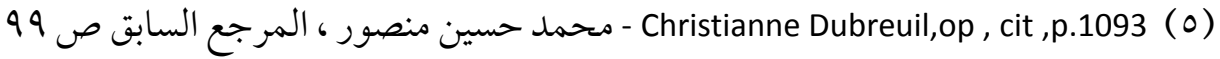


التصريحات الواردة في الاستبيان(1)حيث يعتبر عدم الإعلان عن الظروف المعروفة له بمثابة

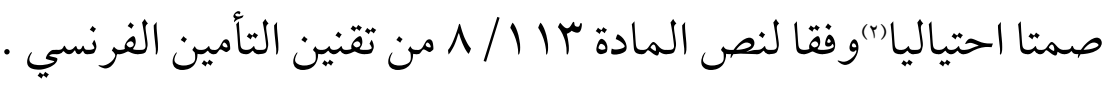
و فقا لهذا الرأي هناك امتداد لحسن نية المؤمن له ، حيث يجب عليه بالإضافة إلى الإجابة بالضبط عن الأسئلة التي طرحها المؤمن أن يعلن تلقائيا عن أية وقائع وحقائق يعرفها والتي يكون لها الأثر في تقييم المخاطر ، فإذا كان البيان ليس من شأنه أن يغير من محل الخطر ولا أن يتتقص من تقدير المؤمن لجسامة الخطر فإن المؤمن له لا يكون ملتزما بتقديمه ولو طلبه المؤمن(م)، لذلك فإن فشل المؤمن له في إعلان الظروف التي يمكن للمؤمن تجاهل أهميتها بشكل شرعي من وجهة نظر شركة التأمين لم يعد يعاقب عليه(i) وبذلك يكون هناك جمع بين طريقتي الإعلان التلقائي والاستبيان .

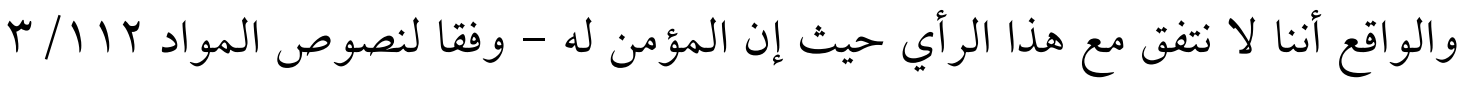
r/ I/ من تقنين التأمين الفرنسي التي تلزم شركة التأمين باستجواب مقدم الطلب بنفسه عن الظروف التي تسمح بتقييم المخاطر - لم يعد مطالبا بالإعلان عن الظروف المعروفة له تلقائيا، ويترتب على ذلك أنه إذا امتنعت شركة التأمين عن طرح سؤال بخصوص مسألة ما فإن المؤمن له يعفي من الإعلان التلقائي عن هذه المسألة بالذات ، ولا يمكن قيام مسئوليته عن عدم الإعلان (م). - (م).

فبعد استبدال نظام الإعلان العفوى بالرد على الأسئة التي تطرحها شركة التأمين بالضبط

(1) Henriette E. Kameni, op , cit, p.18

(2) www.scribd.com.( Khlifi-Taghzouti-Ichraq, Rifai Ali et G'riguaa Nassim, La bonne foi dans le contrat d'assuranc Faculté des Sciences Juridiques Economiques et Sociales de Fés, Master Droits des Transports ,p.5)

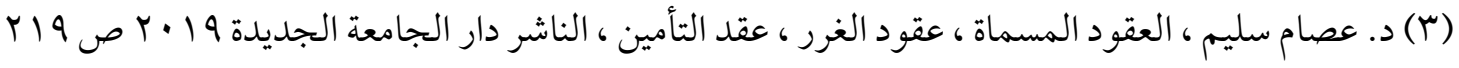

(4) cass. ch. 1ère ch. civ. 24 nouv. 1999, RGDA, 2000, p. 55, note J. KULLMANN

(5) Civ. 2e, 15 fevr. 2007, n 05-20.865, Bull. civ. II, n 36; D. 2007. Jur. 1635, note D. NOGUERO; RDI 2007. 320, obs. P. DESSUET; RCA 2007, Comm. N 172, note H. GROUTEL; RGDA 2007. 327, note S. ABRAVANEL-JOLLLY. 
لاسيما الاستبيان الذى أصبح مغلقا ، يبدو أن تعاون المؤمن له أصبح محدودا ، ولن يتعرض المؤمن له لأية عقوبة لعدم إعلانه إذا أجاب على الاستبيان بالضبط ـ فحقيقة عدم الكشف عن ظرف لم يكن موضوع أي سؤال من المؤمن لا يمكن اعتباره صمتا احتياليا"(1)كلك يجب على القضاة أن يبينو ابوضوح أن المؤمن سأل سؤالا لم يرد عليه المؤمن له أو لم يجيبه بشكل صحيح ، وبالتالي فلن يتم إبطال عقد التأمين إلا إذا كان المؤمن له لا يجيب بصدق على

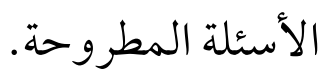

كذلك فإن نظام الاستبيان كما هو وارد في القانون الفرنسي لا يحظر على المؤمن له المحتمل التقدم بإعلان تلقائي للإعلان الأولى ، وهذا هو موقف محكمة النقض الفرنسية في بعض أحكامها()، فمن الناحية العملية فإن للمؤمن له مصلحة في الإعلان التلقائي إذا كان سيحصل على تخفيض في قسط التأمين ، ولكن سيتم معاقبته على الإعلان الكاذب التلقائي بنفس الطريقة كإجابة غير دقيقة على أسئلة الاستبيان ، فالسلوك العفوي يعاقب عليه في حال عدم دقته حتى لو كان غير مطلوب قانونام) . فمن وجهة نظر الدائرة الثانية بمحكمة النقض الفرنسية أنه يجب الأخذ بمفهوم واسع للإعلان عن المخاطر ، فبجانب الإجابات على الأسئلة المطروحة في الاستبيان ، يعترف بالإعلان المكتوب مسبقا من المؤمن له سواء كان مسبوقا بأسئلة أم لا ، كما يعترف بالأسئلة

(1)- cass.1re Civ., 22 mai 2002, Bull. 2002, I, no 136, pourvoi no 00-12.419; 1re Civ., 28 mars 2000, Bull. 2000, I, no 101, pourvoi no 97-18.737 ; 1re Civ., 7 octobre 1998, Bull. 1998, I, no 280, pourvoi no 96-17.315.

(2) Cass. 2e civ., 19 févr. 2009, n 07-21655 ; Cass. 2e civ., 4 févr. 2016, n 15-13850, LEDA 2016, n 4 , comm. 48, S. Abravanel-Jolly

$$
\text { (r) اعتبرت محكمة النقض( الدائرة المدنية الثانية ) أن السلوك الطوعي الكاذب للمؤمن له معاقب عليه }
$$

Cass. 2e civ., 30 juin 2016, n 15-18855, PB, LEDA 2016, nº 8 ; comm. 109 note A. Astegiano-La Rizza; RGDA 2016, p. 403, note L. Mayaux. 


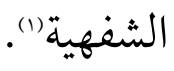

فيمكن للمؤمن له المحتمل أن يعلن المؤمن بكل الظروف التي تكون مؤثرة في الخطر ويقصد بها الظروف والوقائع والملابسات التي تمكن المؤمن من اتخاذ قرار بشأن قبول أو رفض التأمين أو بشأن تحديد قيمة التأمين وقيمة القسط ، وهذه الظروف قد تكون ظروفا موضوعية ، وقد تكون ظروفا شخصية (r). فيما يتعلق بالظروف الموضوعية وهي تلك التي تتعلق بموضوع الخطر المطلوب التأمين منه والتي تتغير بتغيره(ف)في تؤثر في صفات الخطر سواء درجة احتمال تحقق الخطر أو درجة جسامته وتؤثر بالتبعية على قيمة القسط (s). وهذه الظروف تختلف بحسب نوع التأمين ، ففي التأمين على الأشياء يجب على المؤمن له أن يحيط المؤمن علما بطبيعة الشيء المؤمن عليه ، مكوناته ، مادة صناعته ، تاريخ شرائه الغرض المخصص لاستعماله ، موقعه ، ومدى قربه أو بعده عن مصادر الخطر، وقيمته المادية.

في التأمين من المسئولية عن حوادث السيارات يجب على المؤمن له أن يحيط المؤمن علما بماركة السيارة ، سنة الصنع ، الغرض المخصصة لها ، ومهنة المؤمن له . في التأمين على الأشخاص يجب على المؤمن له أن يحيط المؤمن علما بسن المؤمن على حياته ، حالثه الصحية ، مهنته ، وغير ذلك من البيانات .

(1) Cass. 2e civ., 17 févr. 2011, n 09-72793, RGDA 2011, p. 683, note S. Abravanel-Jolly ; Cass. 2e civ., 14 avr. 2016, $n^{\circ} 15-16808$ et $n^{\circ} 15-18226$, RGDA 2016, p. 357, note A. Pélissier. - M.-O. Barbaud, La preuve de la fausse déclaration d'assurance, Resp. civ. et assur. 2016, Étude 9

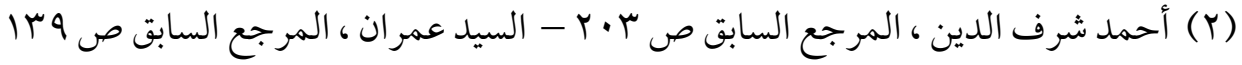

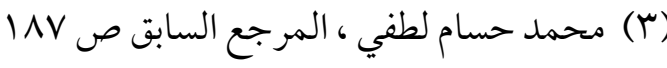

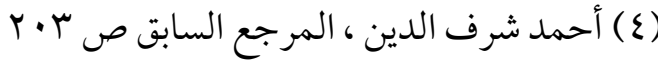


أما بالنسبة للظروف الشخصية أو الذاتية فهي تلك التي تتعلق بشخص المؤمن له من حيث أخلاقه ، وتصرفاته العامة وسلوكه بصفة خاصة في مجال التأمين(1)،وتاريخه الجنائي (()،وعلاقاته السابقة مع شركات التأمين(r)، وتفاصيل الاتصال بمؤمنه السابق ()، وعدد وثائق التأمين التي سبق له إبرامها عن ذات الخطر (م) الرفض المسبق لأي تأمين أو مطالبة

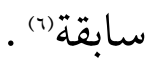

في بعض الأحيان لا يكون لهذه الظروف التي سيتم الإعلان عنها تأثير على معدل القسط ولكن لها تأثير على رأي المؤمن بقبول أو عدم قبول عقد التأمين (v). فهذه الظروف حقائق غير قابلة للتأمين في حد ذاتها إنما تتعلق بالشخص المؤمن له فيما يتعلق بأخلاقه ومثابرته أو ملاءته هذه الظروف توصف بشكل عام بأنها "مخاطر ذاتية" مختلفة عن الظروف التي قد تؤدي بالمؤمن لطلب قسطا أعلى أو أقل ـ فهذه الظروف قد تجعل المؤمن حذرا من المؤمن له ويفضل الامتناع عن التعاقد (م). وسوف نتطرق ببعض من التفصيل لمسألة أخلاق المؤمن له وبخاصة في مجال التأمين حيث تعد مسألة نزاهته الأخلاقية من أحد الأمور الأساسية التي يمكن النظر إليها من قبل شركات التأمين عند الدخول في علاقة تعاقدية مع مؤمن له محتمل ، والسؤل دائما هو ما إذا كان شخص المؤمن له شخص تسعد به شركة التأمين عند قيامها بالتعاقد معه أم لا ؟

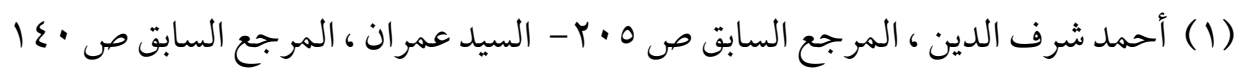

(2) Yiqing Yang , op , cit ,p.192

(3) Camila HABOUBI ,op, cit, no 198

(4) Cass. 1 re civ., 19 Mai 1969, Gaz. Pal. 1969, 2, p.98

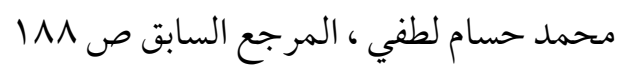

(6) Yiqing Yang , op , cit ,p199 - Camila HABOUBI ,op, cit, no 198

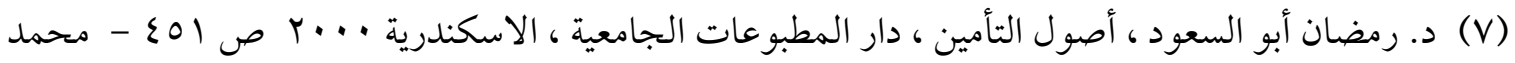

(8) Picard et André Besson, , op,cit , p. 126.

$$
\text { حسين منصور ، المرجع السابق ص } 99
$$


إن هوية الشخص بالضرورة حقيقة جوهرية ؛ لذلك في بعض الأحيان تعتبر المخاطر الأخلاقية أكثر أهمية من المخاطر المادية ، فإذا كان المؤمن له المحتمل يجب عليه الرد بصدق وإخلاص على أسئلة شركة التأمين ؛ وذلك لأنها تعتمد على إجاباته في تحديد مبلغ التأمين وتكلفته، لذلك فإن عدم صدقه أمر له صلة بالمخاطر الأخلاقية .

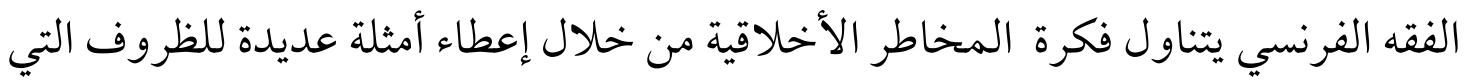
تتكون منها ، بالإضافة إلى ذلك فإنه ركز على وصف تأثير الظروف التي تشكل خطرًا أخلاقيًا على رأي المؤمن". (1).

إن المخاطر الأخلاقية تتكون بشكل أساسي من الظروف التي تشكل جزءًا من التاريخ

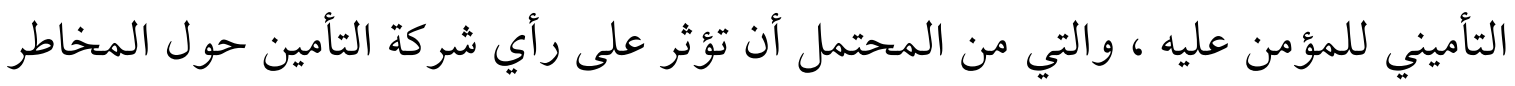

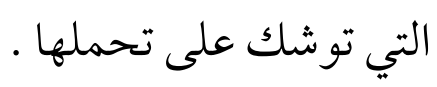

فالظروف الشخصية للمؤمن له هي تلك التي تهم المؤمن : هل هو مؤمن بنفس الخطر؟

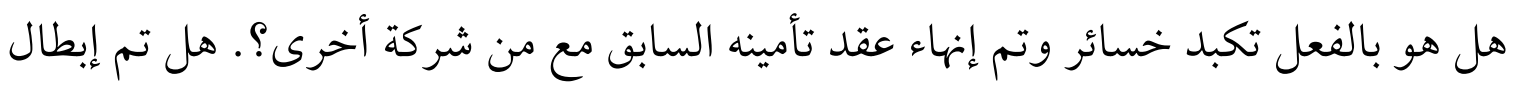
رخصة قيادته ، أو أنه تعرض لإدانات مدنية أو جنائية تتعلق بحو ادث مركبة سابقة؟ إلخ.

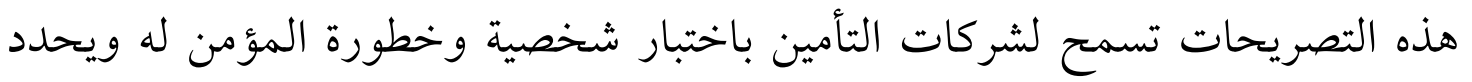
مو افقته على التعاقد (").

ويعد من بين المسائل الهامة المرتبطة بفكرة المخاطر الأخلاقية مسألة الإدانات الجنائية السابقة في مجال التأمين". (r)

فمعظم شركات التأمين تسأل عن الإدانات الجنائية ؛ لأنها تعتقد أنها ذات صلة بالمخاطر

(1) Vincent Caron . L'obligation de divulgation et le risque moral en assurance de dommages, Maître en droit de la Faculté de droit de l'Université Laval.2008 P.115

(2) Yvonne Lambert-Faivre, Droit des assurances, 12 éd., Paris, Dalloz 2005, p. 259-260

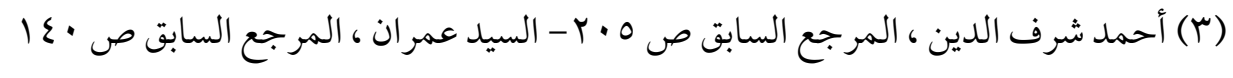


على الرغم من أن هذا يبدو غير عادل في كثير من الأحيان ، إلا أنه يحق لشركة التأمين أن تقرر قبول الضمان أو تختار عدم الضمان حسبما تراه مناسبا.

ولا يعد إعلان المؤمن له عن الإدانات الصادرة ضده من المحكمة انتهاكا للحق في احترام

حياته الخاصة ؛ وذلك لأن هذه الأحكام تصدر في جلسات علنية متاح لجميع الناس رؤيتها. فحسن نية المؤمن له المحتمل تنطلب منه الإفصاح عن أي إدانات جنائية")سابقة سواء أكانت هذه الإدانات نهائية أو غير نهائية (r).

كذلك الحال فإن الحكم على المؤمن له بإدانة جنائية أثناء سريان عقد التأمين تعتبر ظرفا جديدا يفاقم المخاطر ويعدل تقييمها ؛ ومن قبيل ذلك إدانة المؤمن له أثناء القيادة في حالة سكر للذك يجب على المؤمن له أن يعلنها للمؤمن وإلا تعرض للعقوبة المقررة لعدم الإعلان عن تفاقم المخاطر (r) - أ.

فيما يتعلق بالإدانات الجنائية التي تتأثر بقانون إعادة تأهيل المجرمين أو ما يعرف برد الاعتبار والذى يترتب عليه اعتبار العقوبة الجنائية بعد فترة معينة كأنها غير موجودة وكأنها لم تحدث من قبل ، فهذه الإدانات ليس مطلوبا من المؤمن له المحتمل الكشف عنها أو ظروفها ()أو حتى حقيقة أنه ارتكب الجريمة من الأساس().

كما أن أي سؤال من المؤمن عن الإدانات السابقة يعتبر أنه لا يشير إلى مثل هذه الإدانات التي اعتبرها القانون غير موجودة ، ولن يعاقب المؤمن له بأي عقاب في حال عدم كشفه عنها وذلك لأنها ليست موضو عا للإعلان(1).

Yiqing Yang , op , cit ,p.192 - (1) أحمد شرف الدين ، المرجع السابق ص 0 (1)

(2) - (Cass, II) Chapitre civil, 29 avril 2004, Jurisp. Le moi. 2004, voir ci-dessous, p. 361.

(3) Cass. crim. 2 mai 2001, ${ }^{\circ} 0085532$, RGDA 2001, p. 699, note $\mathrm{c}$

(4) - Cass.1re civ., 16 Février 1988, n 86-12.238, note J. Bigot, RGAT 1988, p. 47

(5) Cass.1 Re civ., 9 Avril 1991, RGAT 1991, p. 555, note H. Margeat et J. Landel

(6) Camila HABOUBI ,op, cit,, no 78 
أما فيما يتعلق بالادعاءات المتعلقة بالإجرام والشائعات فإنه لا يوجد أي واجب على المؤمن له بالكشف عن هذه الوقائع عند تقديمه طلب التأمين (1).

حتى أنه سيكون من الصعب على شركة التأمين الحصول على بطلان العقد فقط لمجرد الادعاء بأن المؤمن له تعاملات مع المجتمع الإجرامي ، فهذا النوع من الادعاء غير كافٍ بشكل واضح للحصول على بطلان العقد حيث يجب على شركة التأمين إثبات أهمية هذه الظروف ، كما هو الحال مع السجل الجنائي وتحديد مدى أهمية التهديدات الموجهة ضد

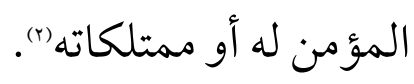

أما بخصوص الملاحقات القضائية المعلقة والتي قد تعنى اتهام المؤمن له في جريمة أو حتى مجرد القبض عليه فإن المؤمن له المحتمل ملزم بالكشف عن هذه التهم ، كما يحق له أن يقدم إلى شركة التأمين أدلة إثبات براءته (r). فيجب على المؤمن له أن يكشف لشركة التأمين عن أي معلومات في حوزته عن أية ادعاءات بالإدانة الجنائية لنفسه أو عماله أو موظفيه، وكذلك الإفصاح عن الأدلة التي تدعم تصريحه

كذلك الحال بخصوص وثائق التأمين السابقة يتعين على المؤمن له توضيح تاريخ التأمين السابق ونوعه وأسباب عدم الاستمر ار فيه (o) فيتعين عليه توضيح خسائره السابقة والمطالبات المتعلقة بهاء() ، وكذلك توضيح الرفض السابق للمطالبات حتى ولو كانت هذه المطالبات

(1) Yiqing Yang, op, cit .p. 195

(2).- Vincent Caron . op , cit.P.134

(3) Yiqing Yang, op , cit , p. 196

(4) Ibid.

$$
\text { محمد حسام لطفي ، المرجع السابق ص } 199
$$

(6) Karen Ann Gill , Insurance fraud, causes, characteristics and prevention, a thesis for the degree of Doctor University of Leicester, September 2001, p.153 
تختلف كليا عن موضوع عقد التأمين المزمع إبرامه مع المؤمن (1)وذلك لأنها تعطى فكرة عن المخاطرة المحتملة التي قد تتعرض لها شركة التأمين والتي تنجم عن معرفة خصائص

$$
\text { وسلو كيات المؤمن له المحتمل. }
$$

ع -الظروف الجديدة التي تنشأ في الفترة بين الإعلان الأولى وإبرام العقد قد يكون هناك تأخير طويل إلى حد ما بين الإعلان الأولى للمخاطر وإبرام عقد التأمين وذلك لأن كل عقود التأمين لا يتم إبرامها بسرعة ، حيث يكون هناك مهلة ، قد تكون طويلة للتفكير من قبل المؤمن له المحتمل (r).

يجب افتراض أنه قد تنشأ ظروف جديدة متعلقة بالمخاطر في خلال الفترة بين الإعلان الأولى للمؤمن له للمعلومات المتعلقة بالمخاطر ولحظة إبرام العقد ودخوله حيز التنفيذ ،

و هذه الظروف قد تجعل المعلومات المقدمة من المؤمن له استجابة للاستبيان غير دقيقة . الواقع أن النصوص القانونية المتعلقة بعقد التأمين لم تتحدث عن هذه الفترة المتوسطة بين الإعلان الأولى للمخاطر وإبرام العقد ، كما لم تتطلب طرح أسئلة عن هذه الفترة"(r). تم العثور على هذه الفترة المتوسطة بشكل رئيسي في المخاطر المعقدة (كالمخاطر البيئية و الصناعية) ، حيث إن التأمين على هذه المخاطر يتطلب دراسات وخبرات مختلفة من قبل الطرفين؛ أي أن الأطراف المتعاقدة من أجل ضمان أداء التزاماتها المقبلة يجب أن تبقى لفترة طويلة في مرحلة تبادل ما يسمى بوثائق الأسئلة والأجوبة التي تتعلق بالطبيعة القانونية للمخاطر المتعلقة بعناصر عقد التأمين (s). رأت محكمة النقض الفرنسية أن الالتزامات التعاقدية المرتبطة بالالتزام بالكشف عن

(1) Yiqing Yang , op , cit ,p. 200

(2) Camila HABOUBI ,op cit, no 98-99

(3) V. J. BIGOT, Discrimination, droit européen et national, R. du Courtage, Juillet 1993, n673, p677

(4) Lamy assurances,2008, op.cit, p. 768 et s. 
الظروف الجديدة في عقد التأمين لها نطاق واسع يشمل بما في ذلك كامل فترة ما قبل التعاقد فيجب على المؤمن أن يبادر إلى إعلان شركة التأمين بهذه الظروف الجديدة بعد الإجابة على الأسئلة المطروحة(1) التي قد تؤدي إما إلى زيادة المخاطر أو إلى خلق ظروف جديدة والتي تجعلها غير دقيقة ، وتنقضي الإجابات المقدمة إلى شركة التأمين لا سيما في نموذج إعلان المخاطر (r) ويترتب على هذا الإعلان عن الظروف الجديدة قبل إبرام العقد حصول شركة التأمين على رأي دقيق حول المخاطر ، فتقوم بتعديل التغطية ، إلا إذا كانت المخاطر كبيرة للغاية فيجوز لها أن تتخلى عن التعاقد(r). ويرى بعض الفقه (s)أنه يحق للمؤمن تجديد الاستبيان الذى يعتقد بأن المعلومات الواردة فيه قد أصبحت قديمة فيستجوب المؤمن له مرة أخرى دون انتظاره لتعديل إجاباته(فيكون للمؤمن إمكانية إرسال استبيان جديد للمؤمن له إذا استمرت الفترة السابقة للتعاقد مدة طويلة ويكون لهذه المبادرة تذكير للمؤمن له بأهمية تبادل المعلومات أثناء الاشتراك ، وعلى أن يقتصر تكرار بيان المخاطر على الاشتراكات التي يطول فيها الفترة بين الإعلان الأولى للمخاطر وإبرام العقد(1) ، كذلك يتم اعتماد نفس الحل بخصوص الفترة التي تفصل بين إبرام

(1) يجب أن يتم الإعلان أثناء إبرام عقد التأمين ، أي فترة المفاوضات التي تسبق العقد ، فحتى لحظة هذا التوقيع يجب أن يعلن طالب التأمين ظروف الخطر سواء تلك الموجودة وقت تقديم الطلب أو تلك التي استجدت

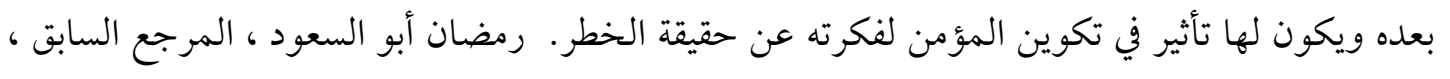

$$
\{\tau Y-\{\tau\rceil ص
$$

(2) cass.1er civ. 31 mars 1998, n95-21.986, n 612, RGDA 1998, p.254 note A. FAIVRE-ROCHEX. RCA. 1998, comm. $n^{\circ} 215$, obs. H. GROUTEL-Cass. 1 re -

(3)- Camila HABOUBI, op, cit , no 95

(4) L. Mayaux, Le temps et l'évolution du risque, colloque AIDA Le facteur " temps » dans l'assuranc, RGDA 2002, p. 1110 - Camila HABOUBI ,op, cit , no 100

(5) En ce sens, L.Mayaux sous Cass. 2e civ., 7 déc. 2006, n 05-20430 RGDA 2007, p. 72

(6) Camila HABOUBI, op, cit, no 101 
عقد التأمين وسريانه ؛ وذلك حين يكون تاريخ سريان عقد التأمين بعد مدة من تاريخ إبرامه(1) في خلال هذه الفترة لا يلتزم المؤمن بتغطية الخطر في حال حدوثه("). ومع ذلك فإن طبيعة هذا الإعلان بخصوص طول الفترة بين الإعلان وإبرام عقد التأمين تتطلب بعض التوضيحات. ففي الواقع لا يعد هذا الإعلان إعلانا عن المخاطر خلال العقد بسبب المخاطر الجديدة ، حيث لم يتم إبرام عقد التأمين بعد. وبالتالي ، فإن النظام القانوني المعمول به هو نظام إعلان المخاطر الأولي (r) وليس النظام القانوني لتفاقم المخاطر . علاوة على ذلك يجب أن يُفهم هذا الإعلان على أنه امتداد للالتزام بالإجابة على الأسئلة التي تطرحها شركة التأمين بالضبط ، وليس كالتزام بالإعلان التلقائي.

$$
\text { 0- المسائل التي لا يلزم الكشف عنها }
$$

إذا كان المؤمن له مطالب بالإجابة بدقة وأمانة عن الأسئلة التي طرحها عليه المؤمن في الاستبيان، إلا أن عدم امتثاله للإجابة عن استفسار ات وأسئلة المؤمن لا ترقى إلى اعتبارها إخلالا بو اجب الكشف النزيه عن المعلومات ، كما لا يعاقب عليه في بعض الحالات() حيث توجد بعض الظروف والمسائل المتعلقة بالخطر والتي لا يلتزم المؤمن له بالكشف عنها وهذه المسائل هي الظروف التي تقلل من المخاطر ، والظروف التي يعلمها المؤمن ، وتنازل المؤمن عن المعلومات (أ) تقليل المخاطر فلا يلتزم المؤمن له بإعلام المؤمن بما يقلل المخاطر المتفق عليها(م)، وذلك لأن هذه

(1)- Cass. 2e civ., 22 janv. 2009, n 07-20738, RGDA 2009, p. 98, 2e esp. note L. Mayaux ; Cass. 2e civ., 24 nov. 2011, $n^{\circ} 10-27119$.

$$
\text { محمد حسين منصور ، المرجع السابق ص ع } 9 \text { (Y) }
$$

(3) H. Groutel, déclaration de risque, circonstance nouvelle entre, la proposition d'assurance et la conclusion du contrat, RCA. 1998, comm. $n^{\circ} 6$, p. 23

(4) Yiqing Yang , op , cit , p.218

(5) Ibid,p.201 
البيانات لا تأثير لها في تحمل المؤمن أعباء تزيد عما هو متفق عليه ، بل على العكس فإن تقليل المخاطر يكون في مصلحة المؤمن . ومع ذلك فإن هذه الظروف الجديدة يجب أن يقابلها خفض في تكلفة التأمين بشرط أن

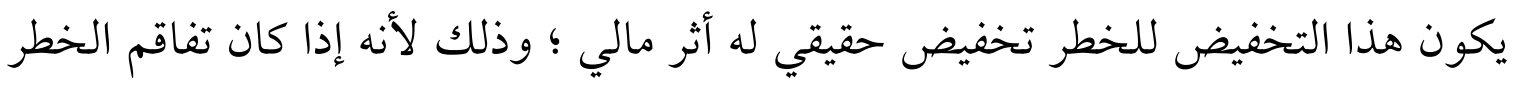

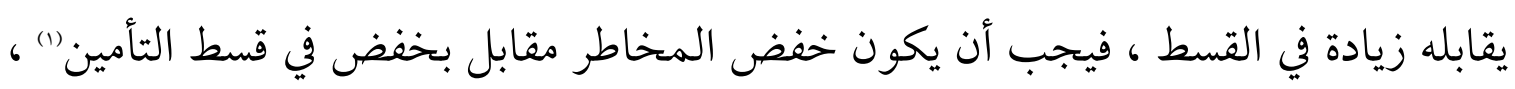

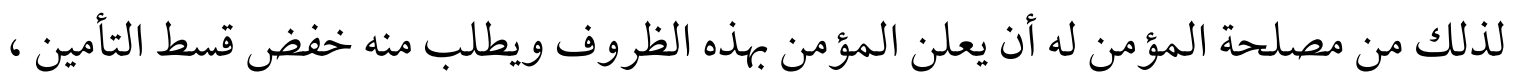

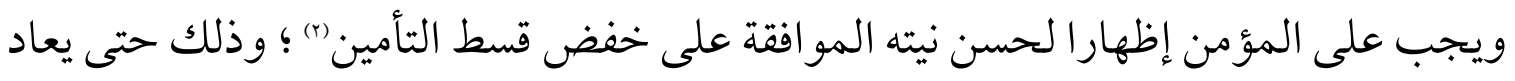
التوازن المالي للعقد وفي حال رفض المؤمن يحق للمؤمن له أن يعلنه بخطاب مسجل بإنهاء

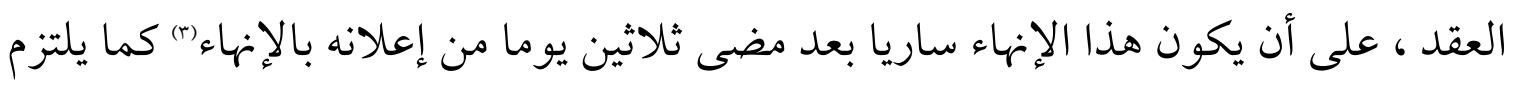

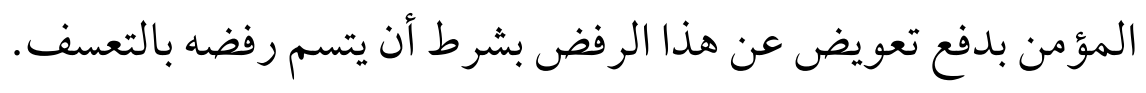

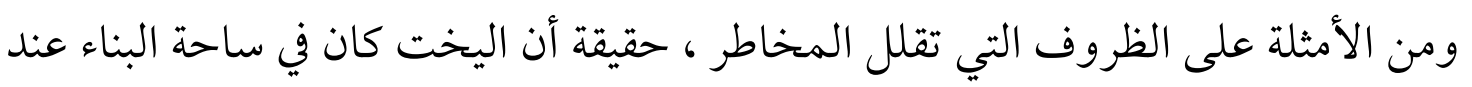

$$
\begin{aligned}
& \text { بداية التعاقد أو أنه كان في مرسى آمن ومحمبم" (s). } \\
& \text { (ب) الظروف التي يعرفها المؤمن }
\end{aligned}
$$

إن معرفة شركة التأمين لأي ظرف متعلق بالمخاطر المؤمن عليها يعفي المؤمن له من

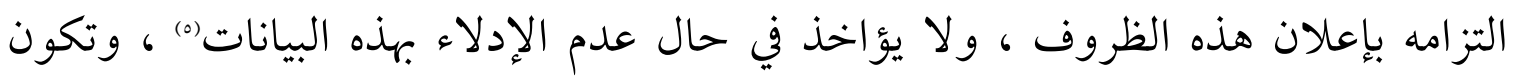

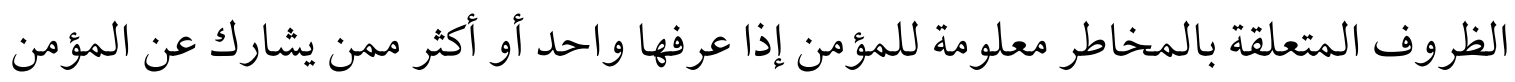
في اتخاذ قرار قبول التأمين على مخاطر المؤمن له :

(1) Y. LAMBERT-FAIVRE , 2005, op. Cit, p.265.

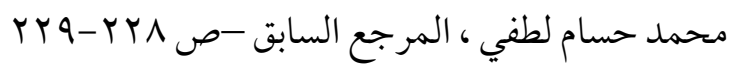

(3) Y. LAMBERT-FAIVRE, 2005, op. Cit, p.266

(4) Yiqing Yang , op , cit ,p.202

$$
\text { (0) رمضان أبو السعود ، المرجع السابق ص (0) - محمد حسين منصور، المرجع السابق ص } 99
$$


وهذه المعرفة قد تكون معرفة فعلية كمعرفة المؤمن نفسه ، أو أحد موظفي ، أو وكيل شركة التأمين الذين شاركوا في عملية صنع القرار بخصوص عقد التأمين ، وكذلك معرفة فريق الإدارة العليا لشركة التأمين الذى يتم إبلاغه بكافة البيانات المتعلقة بعملية التأمين بخاصة إذا كانت المخاطر كبيرة جدا ولابد من إبلاغه بها . كذلك فإن المعرفة المحدودة للمؤمن ويعبر عنها بأنها الأمور التي يشتبه الفرد فيها والتي يكون لديه معرفه عنها لكنه امتنع عن تأكيدها أو الاستفسار عنها' (1). كذلك الحال بالنسبة للظروف التي يجب أن يعرفها المؤمن وهذا معناه أن هناك بعض الأشخاص التابعين لشركة التأمين ولديهم المعلومات المتعلقة بالظروف المتعلقة بالخطر ويجب أن تكون المعلومات في حوزتهم بالفعل وذلك حتى نفترض علم المؤمن بهذه المعلومات(()فيعتد بمعرفة أي شخص يتقدم لمفاوضة المؤمن له(r). فوكيل الشركة في مرحلة الاقتراح إذا كان يتصرف بهذه الصفة فإننا نفترض علم الشركة بكل المعلومات التي يعرفها وذلك لأن المعلومات التي تكون لديه يكون لها دور كبير في اتخاذ قرار التأمين من عدمه . كذلك الحال بالنسبة للمعلومات التي يعرفها الطبيب المكلف من قبل شركة التأمين لفحص المؤمن له المحتمل (8)، وكذلك المعلومات التي يعرفها المساح الذى يطلب منه تقرير عن الموقع الذى سيؤمن عليه ، وبالمثل المعلومات التي يعرفها المدقق المعين لفحص الأمن المادي وأنظمة التحكم لأحد البنوك .

(1) Yiqing Yang , op , cit , p.203

(2) Camila HABOUBI ,op,cit, no 709

$$
\begin{aligned}
& \text { محمد حسين منصور ، المرجع السابق ص } 99 \\
& \text { رمضان أبو السعود ، المرجع السابق ص }
\end{aligned}
$$


كذلك الحال بالنسبة للمعلومات التي تحتجزها شركة التأمين بسجلاتهالبخصوص

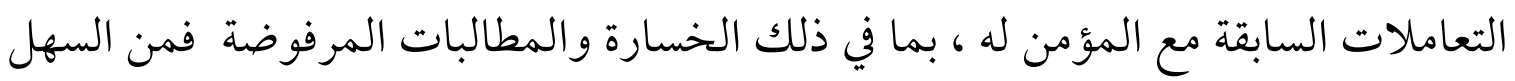
للمؤمن الحصول على هذه المعلومات طالما أنها داخل منظمته خاصة في ظل وجود أنظمة التكنولوجيا الحديثة ، وأجهزة الحاسب الآلي ، ووسائل الاتصال الحديثة(')فمن المتوقع أن تتحقق شركة التأمين من أنظمة الكمبيوتر الخاصة بها إلا أن شركة التأمين لا يجب عليها لهيها

$$
\text { التحقق من المعلومات التي لديها عن طريق البحث في الإنترنت (م). }
$$

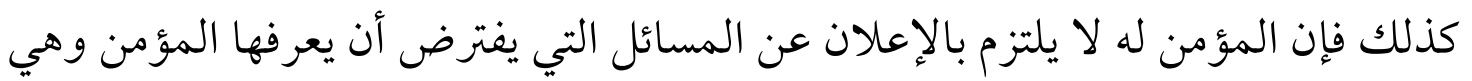
الظروف الشائعة المعروفة للجميع ، وكذلك المسائل التي تقدم لشركة التأمين عند سؤ لهرال

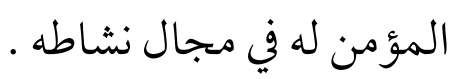

فبخصوص المعلومات المنشورة في الصحف فلا يفترض علم شركة التأمين بها، لذلك لهن خلصت المحاكم إلى أن شركة التأمين لا يفترض أن يكون لديها معلومات وحقائق عن سفن معينة على أساس أن هذه الحقائق منشورة في الصحف (s).

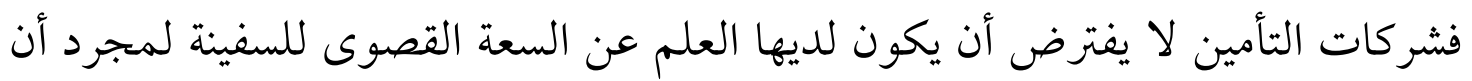
هذه المعلومات نشرت في منتدى إعلامي يستهدف العمل البحري أو نشرت على الإنترنت

(1) يعتبر معلوما للمؤمن ما يو جد في سجلاته ، فإذا كان لطالب التأمين عدة وثائق لدى نفس المؤمن فإن ما ورد في

$$
\begin{aligned}
& \text { هذه الوثائق من بيانات يعتبر معلوما للمؤمن. }
\end{aligned}
$$

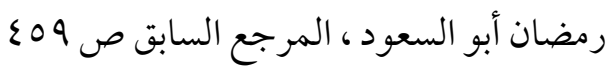

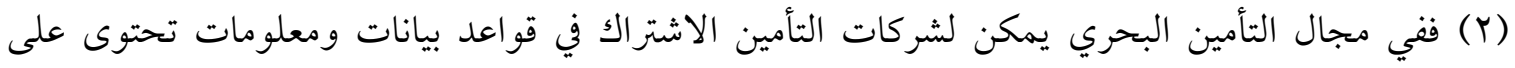

$$
\text { معلومات عن السفن وملاكها وفي هذه الحالة لن يستغرق البحث عن هذه المعلومات سوى بضع ثلإناني. }
$$

Yiqing Yang , op , cit , p.207

(3) Ibid.

(4) Ibid, p.209 


$$
\text { بجريدة الصناعات البحرية) }
$$

فبحث شركات التأمين في شبكة الانترنت عن موضوع التأمين لا يفترض به علم الشركة بالظروف المتعلقة بالمخاطر ، ولا تعتبر المعرفة شائعة بالنسبة للمؤمن ولا يعفي المؤمن له من الإدلاء بالبيانات المتعلقة بها"). على العكس من ذلك من المفترض أن شركة التأمين تعرف ممارسات التجارة التي تعمل بهاب(r) بالتالي يفترض بها المعرفة الأفضل بالمخاطر المتعلقة بالأعمال التي تضمنها أفضل من الشخص العادي" (2) - (1)

$$
\text { (ج) التنازل عن الالتزام }
$$

إن المؤمن له ليس ملزما بالإدلاء بالبيان المتعلق بالخطر في حال غياب استفسار من المؤمن وتخليه عن طلبه ، ويعبارة أدق في حال تنازل المؤمن والذى يمكن أن يكون صريحا بإعلان المؤمن بوضوح أن الظروف ليست ضرورية ليتم الكشف عنهاهـا. ويمكن أن يكون التنازل ضمنيا ، فشركة التأمين هي التي تطرح الأسئلة المحددة بالاستيان وبالتالي لا يمكن القول بوجود تنازل حيث يوجد سؤال صريح طرح للحصول على معلومات حول تاريخ المطالبات أو الرفض السابق (1). فإذا فشلت شركة التأمين في طرح المزيد من الأسئلة عن الحالة التي تكون فيها المعلومات المقدمة من المؤمن له عند الإجابة

(1) Ibid

(2) Ibid, p.207

(Y) يفترض معرفة المؤمن بالمعلو مات إذا كانت تدخل في مجال تخصصه Mme FABRE-MAHNAN, op ,cit, , Nº 640

(ع) فيفترض أن كل مكتتب تأمين على بينة من ممارسة التجارة التي يؤمنها وبالتالي لو كان هناك مجموعة من

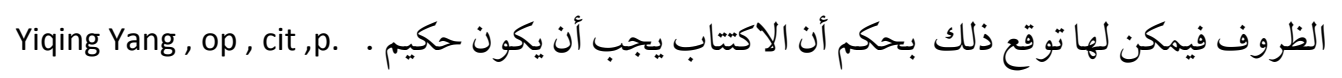

(5) Ibid, p.218

(6) Ibid, p.212 
على سؤال شركة التأمين غير كافية ؛ فإن هذا يعد تخلى منها عن الاستفسار عن المعلومات

$$
\text { ولا تنعقد مسئولية المؤمن له (1). }
$$

ويجب لاعتبار المؤمن له متنازلا ضمنيا عن المعلومات أن يكون هذا التنازل قد استنتج

من الحالات التي تكون فيه المعلومات محدودة ، وذلك بعد حصول المؤمن على معلومات محددة من المؤمن له ولم يبادر بعد ذلك إلى الاستفسار عن هذه المعلومات ، أو أن يستنتج أن المؤمن غير مبال بالحصول على المعلومات(r).

\section{7- التزام المؤمن له بالتعاون لتنفيذ إعلان المخاطر}

عادة ما تستخدم شركات التأمين تقنية فحص المخاطر ، خاصة بالنسبة للمخاطر الصناعية والبيئية الكبيرة (r) ويمكن أن يقوم بهذا الفحص المؤمن نفسه أو أحد موظفيه أو مفتش أو فني.

في التأمين ضد المسؤولية المدنية ضد الأضرار التي تلحق بالبيئة ، يمكن إجراء الفحص بزيارة إما من قبل مهندس متخصص من شركة التأمين التي تم رفع القضية إليها ، أو بواسطة مهندس بيئي. وعلى هذا النحو ، في حالة المخاطر البيئية يحق للمؤمن أو من ينوب عنه أن يقوم في أي وقت بزيارة المنشآت التي يديرها المؤمن له ؛ ليرى مدى التحكم في ظروف أداء أنشطتها أو السيطرة عليها ، وهذه الزيارة تسمح للمؤمن بالتحقق من شروط التأمين على المخاطر. في حالة تعدد المواقع ، من الممكن تحديد مواقع معينة ممثلة لقطاع نشاط المجموعة والقيود البيئية المفترضة").

(1) Ibid, p.211

(2) Ibid , p.212

(3) Cass. 1re Civ. 2 mai 1977, RGAT 1978 p. 42, note A. BESSON

(4) Lamy assurances,2008, op, cit, p.768 
المناقشة مع المؤمن له ضرورية لتمثيل هذا الاختيار؛ لذلك يجب على هذا الأخير أن يتعاون مع شركة التأمين الخاصة به بحيث تظل المخاطر قابلة للتأمين ·

في مفهوم الشر اكة يجب أن نفهم روح هذه المراجعة والتحقق ، حيث إن هذا التحقق يفيد المؤمن له(1)؛ لأنه يجعل من الممكن السيطرة على وجود شروط التأمين ضد المخاطر ، وفي حالة عدم استيفاء هذه الشروط يجوز للمؤمن أن يوضح للمؤمن له التدبير الوقائي اللازم حتى تستوفي الظروف الجديدة -التي تؤثر على الخطر - هذه الشروط. بالإضافة إلى ذلك تشير هذه الزيارة إلى معرفة المخاطر من قبل المؤمن والذى لن يعد بإمكانه الإصرار على أنه لا يستطيع تقييم الظروف التي تؤثر على رأيه("). V - فرض عقوبات على المؤمن له في حال الإدلاء بالبيانات الخاطئة يتعين على المؤمن له أن يكون حسن النية في الإدلاء بالبيانات المتعلقة بالخطر وقت إبرام العقد ، فحسن النية مفترض ويعد من قواعد الحصافة و الحكمة (r). فالمؤمن له يتصرف بحسن نية لتجنب العقوبات التي تقوم بدور رادع في عقد التأمين ؛ وذلك لأن العقوبة هي البطلان وهي عقوبة قاسية (s) يستحقها المؤمن له سيء النية. وسوء النية هو المفهوم المناقض لحسن النية (0)وهو في هذه الحالة الفعل غير القانوني من جانب المؤمن له والمرتكب بهدف الحصول على منفعة لا يستحقها ل). وفي هذه الحالة فإن المؤمن له يكون سيء النية في حالتين : الحالة الأولى عندما يدلى بييانات خاطئة وكاذبة عن الخطر ، و الحالة الثانية عندما يحجم ويمتنع امتناعا مخادعا عن

(1) Ibid, p.770

(2) Cass. 1re Civ. 2 mai 1977 RGAT 1978 p. 42, note A. BESSON

(3) VIALATOUX (J), La morale de KANT, Collection sup, Presses Universitaires de France, 1968, p. 33

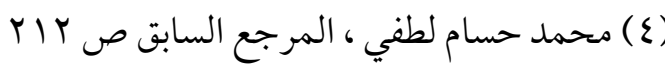

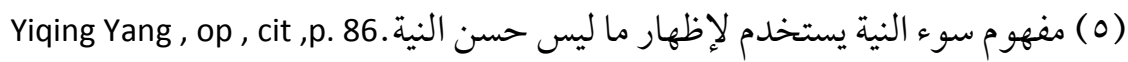

(6) Henriette E. Kameni, op , cit ,p.20 


\section{(أ) الإدلاء بالبيانات الخاطئة :}

البيان هو تأكيد للشخص حقيقة واقعة أو فعل ، والبيانات الكاذبة هي بيانات خاطئة ويحدث سوء نية المؤمن له عندما يتصرف عمدا من أجل حث المؤمن على التعاقد في ظل ظروف لن يقبلها إذا علم بالحقيقة ، أو من أجل تخفيض قيمة القسط الواجب دفعه . هذه البيانات قد تكون متعلقة بشخص المؤمن له : كحالته الصحية ، أو عمره ، أو مهنته أو حالته الاجتماعية ، أو أخلاق طالب التأمين ، ومركزه المالي ، وتاريخه الجنائي ، وعدد الوثائق التي أبرمها من قبل (1)، وقد تكون متعلقة بالشيء المؤمن عليه كطبيعة هذا الشيء والمادة المصنوع منه ، و الغرض المخصص له ، ومكان تو اجده بالقرب أو بالبعد عن مصادر الخطر ، و التدابير الاحترازية ، والأشخاص الذين يستخدمون هذا الشيء().

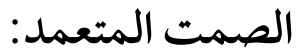

يقصد بالصمت الاحتيالي السلوك غير الأمين من قبل المؤمن له الذى يستخدم الصمت لتجنب الكشف عن حقيقة الخطر الذى يعلمه()" من أجل خداع المؤمن وقت إبرام العقد (2). فالصمت حذف متعمد ، أو إغفال لشيء يجب الإعلان عنه ، ويعتبر هذا الصمت مظهرا

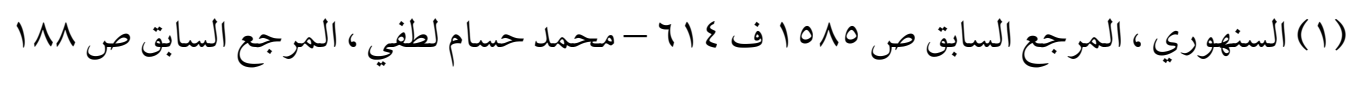

(2) Henriette E. KAMEN , op , cit ,p.20

(r) المقرر في قضاء محكمة النقض المصرية أن عقد التأمين من العقود التي مبناها حسن النية وصدق الاقرارات

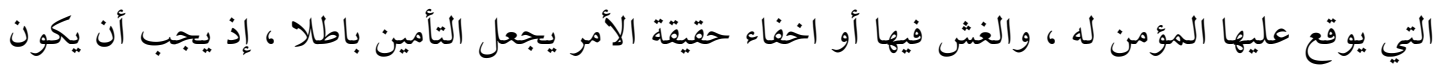

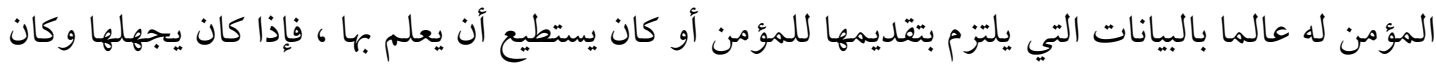

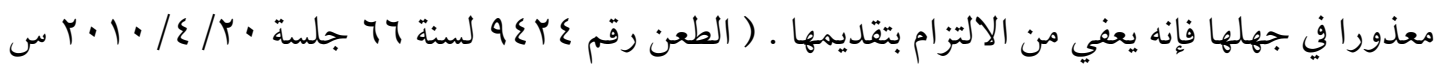

(4) (4) (1)

(4) Henriette E. Kameni, op , cit ,p.20 
من مظاهر سوء النية ،سواء كان هذا الصمت جزئيا بإعلان المؤمن له عن بعض البيانات المتعلقة بالخطر وأوصافه وامتناعه عن البعض الأخر ؛ كأن يعطى إجابات لا بأس بها مع امتناعه عن الدخول في تفاصيل هذه الإجابات (1) مثل إعلان المؤمن له استخدام مخزنه لتحزين الأخشاب ويعلن عن وجود مخزن للجار بجانب هذا المخزن لكنه لا يعلن أن هذا المخزن لتخزين المواد البترولية .كذلك الحال بخصوص التأمين على المنازل حيث يعتبر الصمت احتياليا حيثما يتعلق بعدم دفع أقساط العقد السابق الذى تعهدته شركة تأمين أخرى (r). وكذلك الحال في التأمين الصحي حينما يتعلق الصمت بوجود مرض قبل إبرام العقد (r). وقد يكون الصمت المتعمد كليا وتاما في الحالات التي يكون فيها المؤمن له صامتا تماما عن الإدلاء ببيان عن الحقيقة المطلوبة . ويمكن للمؤمن له أن يجمع في فعل واحد بين الإعلان الخاطئ والصمت المتعمد (8)ومن الأمثلة على ذلك في التأمين الصحي حينما تكون أحد أسئلة الاستبيان عن حالته المرضية خلال سنة ماضية فيجيب بالنفي وحقيقة الأمر أنه امتنع عن الإعلان عن عملية جراحية خضع لها منذ ستة شهور ومن هنا كان الإدلاء بالبيانات خاطئا ومشمو لا بالصمت المتعمد . وقد تفاوتت المحاكم الفرنسية في الحلول التي قدمتها بخصوص إثبات سوء نية المؤمن له عند إدلائه بالبيانات المتعلقة بالمخاطر، ففي حين أن السوابق القضائية(م)رأت بالإجماع أنه وفقا للمادتين r|| / / T- و و | / / من تقنين التأمين يكون هناك سوء نية حيث يكون هناك خطأ في بيان المخاطر بإجابات غير دقيقة على سؤال واضح ودقيق قبل إبرام العقد ، وأن

(1) J. KULLMANN , LAMY Assurances, édicté par LAMY S.A, 2005, p. 202

(2) Henriette E. Kameni, op , cit, p.21

(3) Cass,civ , 16/12/2010 (et appel $n^{\circ} 10-30206, n^{\circ} 10-13768, n^{\circ} 10-12179$ )

(4) Henriette E. Kameni, op , cit ,p.21

(5) Cass. 1re civ., 17 mars 1993, n 91-10041; Cass. 2e civ., 8 sept. 2005, RGDA 2006, p. 74, note S. Abravanel-Jolly. 
السؤال غير الدقيق أو الصعب الفهم يمكن أن يؤدى فقط إلى إجابات غامضة أو غير دقيقة . نشأ اختلاف ملحوظ بين الغرف المدنية والجنائية بمحكمة النقض حول مفهوم إعلان المخاطر:

فذهبت الغرفة الجنائية") إلى الحكم دائما لصالح المفهوم المقيد لإعلان المخاطر بحيث لا يمكن إثبات التحريف المتعمد للمؤمن له إلا من خلال الإجابات على الأسئلة الواضحة و الدقيقة التي تطرح في الاستبيان المقدم من شركة التأمين قبل إبرام العقد. قى حين احتفظت الغرفة المدنية(()مفهوم واسع لإعلان المخاطر ، حيث اعترفت بإمكانية إثبات التحريف المتعمد للمؤمن له ، بالإضافة إلى الإجابات على الأسئلة المطروحة في الاستبيان ، بالإعلان المكتوب مسبقا سواء أكان مسبوقا بأسئلة أم لا ، وسواء ظهر في الاستبيان نفسه ، أو رسالة ، أو فاكس ، أو حتى عندما تكون الأسئلة شفهية. وأمام هذا التفاوت في الحلول تدخلت الغرفة المختلطة(r)وأيدت صراحة موقف الدائرة الجنائية ، وأعلنت أن شركة التأمين لا يمكنها الاعتماد على الصمت أو التحريف المتعمد للمؤمن له لإثبات سوء نيته إلا من خلال إجابات المؤمن له فقط على الأسئلة التي طرحتها عليه في الاستبيان ، وفي حال عدم وجود أسئلة بالمعنى المقصود في المادة r|| / Y-r من تقنين التأمين الفرنسي فلا يمكن تقديم دليل على وجود تحريف مقصود. بعد حكم الدائرة المختلطة سرعان ما تبنت الدائرة المدنية موقفا وسطا ومرنا(ي)حيث قررت اتخاذ موقف الدائرة المختلطة باعتبار أن المؤمن له ملتزم بالإجابة على الأسئلة

(1) Cass. Crim., 10 janv. 2012, n 11-81647, LEDA avr. 2012, note A. Astegiano-La Rizza.

(2) -par ex. : Cass. 2e civ., 17 févr. 2011, n 09-72793, RGDA 2011, p. 683 note S. Abravanel-Jolly

(3) Cass. ch. mixte, 7 févr. 2014, n 12-85107, LEDA mars 2014, p. 1, note S. Abravanel-Jolly ; Resp. civ. et assur. 2014, comm. 99, obs. H. Groutel ; JCP G 2014, n 14, 419, obs. M. Asselain ; D. 2014, p. 1074, note A. Pélissier ; J. Kullmann et L. Mayaux, Déclaration pré-rédigée des risques : deux voix pour un arrêt, RGDA 2014, p. 196.

(4) Cass. 2e civ., 3 juil. 2014, n 13-18760, V. S. Abravanel, Jolly Condamnations des mentions prérédigées, RLDA déc. 2014, p. 77 
الدقيقة التي يطرحها عليه المؤمن لا سيما في نموذج إعلان المخاطر ( الاستبيان ) ، كما أظهرت عدم عزمها على توقف إثبات سوء نية المؤمن له على الاستبيان وحده ، وإنما قبلت كذلك البيانات المكتوبة مسبقا من المؤمن له الذى تسبقه أسئلة دقيقة . ولكن سرعان ما تخلت الدائرة المدنية عن المفهوم المرن لبيان المخاطر وعاودت الرجوع إلى موقفها السابق"(1) فمد فكرة الإعلان الزائف إلى الإعلان المكتوب مسبقا سواء أكان مسبوقا بأسئلة أم لا ، وسواء ظهر في الاستبيان نفسه ، أو رسالة ، أو فاكس ، أو حتى عندما يكون ردا على الأسئلة شفهية.

\section{(ب)بطلان العقد كعقوبة على سوء نية المؤمن له في الإدلاء بالبيانات الأولية}

لم يرد بالتقنين المدني الحالي أي نوع من أنواع الجزاءات على المؤمن له الذى يكتم بعض بيانات الخطر أو يكذب بشأنها ، اللهم إلا ما ورد في المادة ع VI منه فيما يتعلق بالخطأ في سن

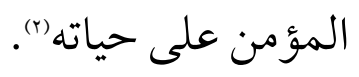

أما القانون الفرنسي فقد نظم هذه المسألة تنظيما عادلا بالمادة ب/ / / من تقنين التأمين و التي تقابل المادة إ من قانون التأمين الفرنسي الصادر عام • ب9 ا والتي أخذ منها مشروع وزارة الاقتصاد بالمادة Tr منه والتي قررت أنه " ا - يقع عقد التأمين باطلا إذا تعمد المؤمن له أو المؤمن على حياته كتمان أمر أو قدم عن عمد بيانا كاذبا وكان من شأن ذلك أن يتغير موضوع الخطر أو تقل أهميته في نظر المؤمن حتى ولو لم يكن للكتمان أو البيان الكاذب أثر

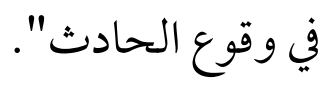

ويرى أغلب الفقه المصري أن تطبيق هذه الأحكام ما هو إلا تطبيق للمبادئ العامة المسلم بها في عقد التأمين وهي تتضمن أحكاما جرت العادة بإدراجها في وثائق التأمين ضمن الشروط

(1) Cass. 2e civ., 14 avr. 2016, $n^{\circ}$ 15-16808 et n 15-18226, RGDA 2016, p. 357, note A. Pélissier Y r (Y) محمد حسام لطفي ، المرجع السابق ص. (Y) 


\section{العامة فأصبحت عرفا تأمينيًا يعتد بهه".}

جديرا بالذكر أن التصريح الكاذب في حد ذاته لا يثير سوء نية المؤمن له ، حيث يمكن أن يكون قد تم نتيجة إهمال أو سوء فهم من المؤمن له ، حيث لا يستطيع المؤمن له وفقا لصفاته الشخصية فهم الأسئلة المطروحة عليه ، وهنا يستبعد سوء النية ().

فعقد التأمين يكون باطلا في حالة وجود كتمان أو تحريف متعمد من جانب المؤمن له عند إدلائه بالبيانات المتعلقة بالخطر عندما يكون من شأن ذلك تغيير موضوع الخطر أو تقليل

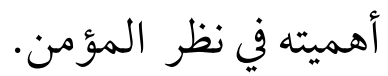

فالبطلان عقوبة المؤمن له سيء النية ، وعلى شركة التأمين التي تدعى سوء نية المؤمن له أن تقيم الدليل على ذلك وعلى تأثير ذلك على تقيم المؤمن للخطر بكل طرق الإثبات(r) ويكون تاريخ تقييم سوء النية من يوم إبرام العقد إذا كان الالتز ام بالإعلان عند إبرام العقد()أما إذا كان الإعلان عن المخاطر خلال فترة العقد فيتم تقييم سوء النية من يوم إصدار هذا الإعلان (o). ولقاضي الموضوع السلطة التقديرية الكاملة لتقيم البيان الكاذب(1)وهو يأخذ في الاعتبار الصفات الشخصية للمؤمن له ، وصياغة الأسئلة نفسها التي تم طرحها، وفي حال وصوله

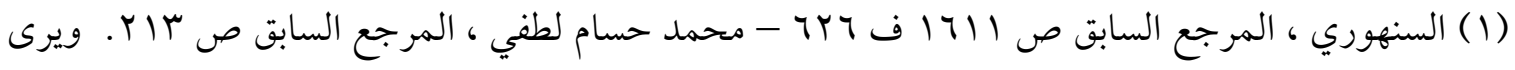
استاذنا الدكتور برهام عطا الله عكس ذلك حيث يقرر أنه في حال خلو التشريع من النصوص فالحل الأمثل هو الته

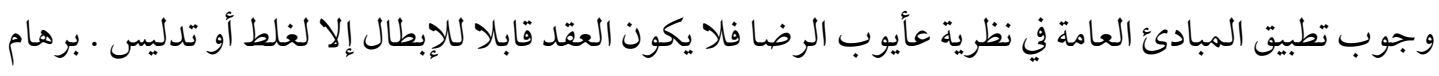

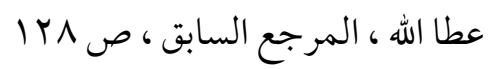

(2) Cas. 1re civ. 12 Juin 1974 : Bulletin civ. 1974, n 181 ; Cas. 1er civ. RGDA 2004, p. 370, note J.KULLMANN

(3)- Cass, CIV 16/12/2010 (et appel $n^{\circ} 10-12179, n^{\circ} 10-1339, n^{\circ} 10-13517-n^{\circ} 10-13768$ )

(4) Cass., crim. 29 Janv. 1991, RGAT 1991. 551, note MARGEATet LANDEL

(5) Cass.1re civ. 16 mars 1971, Bull. civ. n84, RGAT, 1980, note Besson

(6) Cass. 1er civ. 28 mars 2000 : Juris-Data n²000-00 1220. 
لقرار الإدانة والحكم ببطلان العقد فيجب أن يكون ذلك مبنيا على أن التصريح غير الدقيق من قبل المؤمن له متعمد وتم بسوء نية من أجل تضليل شركة التأمين (1) ولذلك فإن أي شك في سوء نية المؤمن له يجب أن يؤدى إلى استبعاد سوء النية . فيما يتعلق بتعدد المخاطر المؤمن عليها فقد رأت محكمة النقض الفرنسية أنه يجب تقييم نطاق هذا الإحجام أو التصريح الكاذب ، فيما يتعلق بكل خطر في النزاع ولكن بشكل مستقل وبتأثير ذلك على تقييم المؤمن ()وبالتالي ، فإن الإعلان الزائف المتعلق بهوية السائق يمكن أن يؤدي إلى تغيير في رأي المخاطر على شركة التأمين ، سواء بالنسبة لخطر المسؤولية المدنية وخطر السرقة أو الحريق.

وفي معظم الأحيان تستخدم شركة التأمين الاستبيان والإجابات المقدمة من المؤمن له كوسيلة لإثبات سوء نية المؤمن له وكمرجع لمقارنه ما أعلنه المؤمن له وما أخفق في الإعلان عنه وما يعرفه حقا ، وكذلك تستخدم مذكرة التغطية ووثيقة التأمين وأية مراسلات أخرى بين المؤمن له وشركة التأمين ، خاصة في الإعلان عن المخاطر المعقدة ، مثل المخاطر البيئية والصناعية حيث الأسئلة والأجوبة المتبادلة بين المؤمن والمؤمن له عند إبرام أو تعديل عقد التأمين (r)

وهذا البطلان ليس بطلانا مطلقا بل هو بطلان نسبى()، ومن ثم فإن المؤمن فقط هو من يستطيع طلبه ، وفي حال طلبه فإنه يتحلل من التزامه(0)، كما أن هذا الحق خاضع للتقادم الوارد

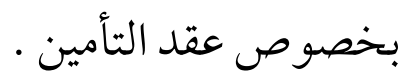

(1) Cass.1re civ. 2 mars 1990, n88-17.955, RGAT 1990, p.603 note J. KULLMANN

(2) Cass civ 1re, 3 janvier 1996, appel ${ }^{\circ}{ }^{\circ} 93-18812$

(3) Lamy assurances,2008, op.cit, p. 768 et s

(4) Christianne Dubreuil, , , op , cit ,p.1093"

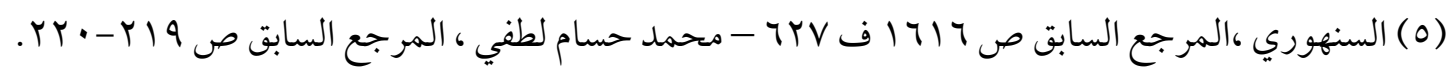


كذلك فإن هذا البطلان له طبيعة خاصة') حيث لا يطبق نظام البطلان الوارد بالقانون المدني بشكل صارم(ف)فلا يشترط وجود علاقة سبية بين الكتمان أو البيان الكاذب وبين تحقق المخاطر أو حدوث ضرر من جراء هذا الصمت أو الكذب المتعمد. فالبطلان يحكم به حتى ولو لم تتحقق المخاطر أو يحدث ضررا للمؤمن." (r).

كذلك يكون لبطلان عقد التأمين أثر رجعى ، لكن هذا الأثر الرجعى له طبيعة خاصة بحيث يمكن للمرء أن يشكك في مدى كفاية المصطلح المستخدم من قبل المشرع (s)حيث يتحلل المؤمن من الضمان من تاريخ إبرام عقد التأمين ، في حين أن المؤمن له يظل ملتزما بدفع الأقساط عن المدة السابقة على استعمال المؤمن له لحقه في الإبطال ؛ ويبرر ذلك باعتبار هذه الأقساط كتعويض عن الأضرار التي لحقت المؤمن بسبب خطأ المؤمن له وخرقه للعقد. كذلك يلتزم المؤمن له برد ما يكون قد قبضه من مبالغ تأمين بمناسبة نفس الوثيقة عن ذات

(1) البطلان هنا خاص بعقد التأمين ، ولا يسرى بشأنه أحكام البطلان في كل آثاره وإن ترتب عليه زوال التزام

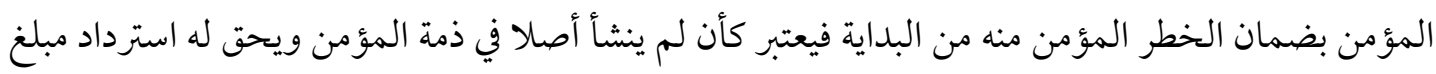
التأمين الذى أداه للمؤمن قبل تقرير البطلان إلا أنه فيما يتعلق بالتزام الأخير بدفع أقساط التأمين فإن ما أداه

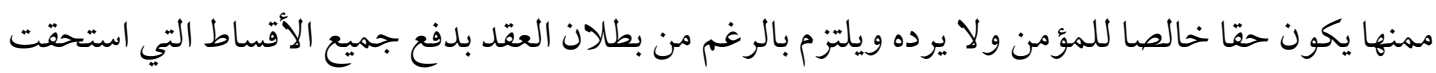

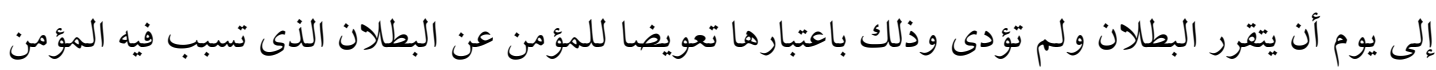

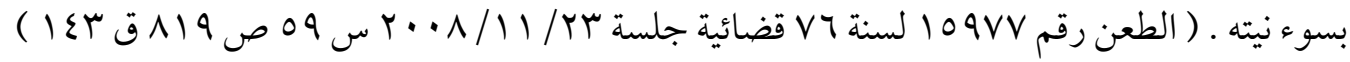
(2) Lamy assurances,2008, op.cit, p.202

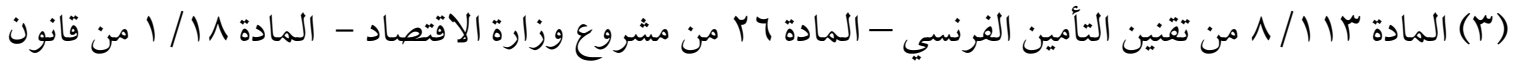
(4) Lamy assurances ,2008, op,cit,p.202 CIMA 
الخطر ، علاوة على الفوائد القانونية عن هذه المبالغ من تاريخ قبضها").

\section{المطلب الثاني \\ حسن نية المؤمـن له وقـت تنفيذ العقد}

لا يقتصر مظهر حسن نية المؤمن له من خلال التزامه بالمعلومات على إبرام عقد التأمين فبمجرد تكوين العقد فإن المؤمن له يجب أن يظل مخلصا وعادلا تجاه شركة التأمين ، فيلتزم بمجموعة من الالنزامات التي يلقيها عقد التأمين علي عاتقه وهي : أداء قسط التامين المتفق عليه ، الإعلان عن كل ما من شأنه أن يؤدى إلى تفاقم المخاطر ، الإعلان عن أي عقد تأمين أخر متزامن يقوم به مع شركة تأمين أخرى بخصوص نفس المخاطر ، الإعلان عن وقوع الحادث المؤمن منه وكذلك التعاون والالتزام بتنفيذ شروط الضمان. أو لا: دفع الأقساط باعتباره مظهر رئيسي لحسن نية المؤمن له. يعتبر الالتزام بدفع القسط من أهم الالتزامات التي يفرضها عقد التأمين على المؤمن له وهذا الالتزام له الأهمية القصوى في جعل عقد التأمين ساري المفعول حيث اضطر اد العمل على اشتراط دفع القسط الأول مقدما وعلى أن يكون هذا الدفع شرطا لبداية نفاذ العقدل. كما أن دفع القسط له أهمية قصوى في الحفاظ على العقد وضمان استمراريته وعلى الضمان المقدم من قبل شركة التأمين (م)؛ فشركة التأمين تتحمل فقط المخاطر المتعلقة بالمؤمن له في مقابل حصولها على قسط التأمين الذى يدفعه وفقا لما هو منصوص عليه في

(1) كل الخصائص السابقة لبطلان عقد التأمين في هذه الحالة دفعت بعض الفقه إلى التشكيك في اعتبار هذا البطلان هو نوع من البطلان التقليدي ، حيث إن رجعية البطلان كانت تتطلب عدة أقساط التأمين للمؤمن له ، لذلك تعتبر هذه العقوبة عقوبة خاصة وأصلية. Y. LAMBERT-FAIVRE, 2005, op. Cit, p.270 - PICARD et A. Besson, , op, cit, , n 91

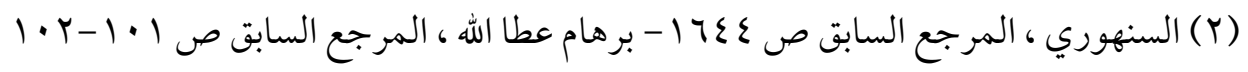

(3) Henriette E. KMENI , op , cit ,p.19 
عقد التأمين المبرم بينهما ، حيث إن القسط من الناحية الفنية والاقتصادية هو تكلفة التأمين"..

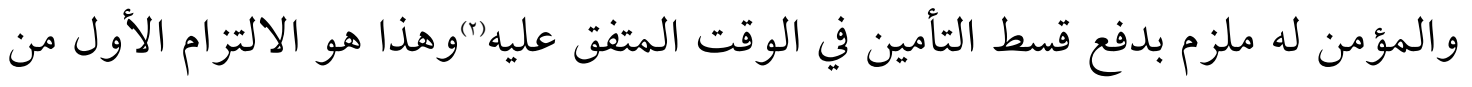

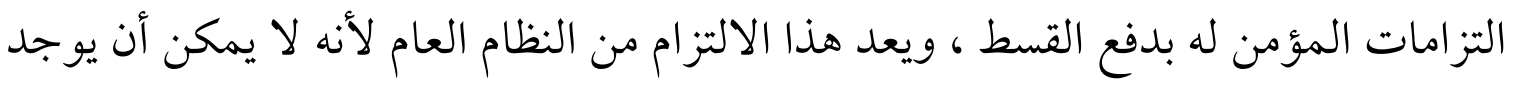
بعقد التأمين بندا تعاقديا يمكن أن يتضمن غير ذلك . لمعن ففيما يتعلق بتصنيف واجبات المؤمن له فإن التزامه بدفع القسط يمكن فهمه كترتيب له الأولوية وذلك بصرف النظر عن تصنيف هذه الواجبات حسب أهميتها(م).

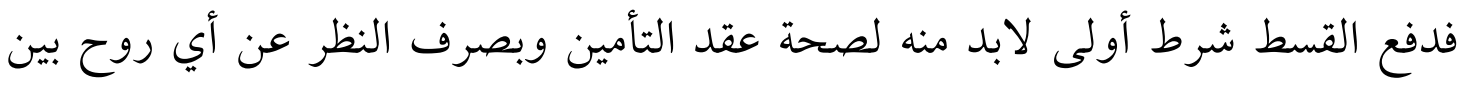
المتعاقدين من حسن أو سوء النية . فالعقد تبادلي وملزم للجانبين ، ودفع القسط هو أحد هذه الالتزامات التي تقع على عاتق المؤمن له والتي قد تكشف عن حسن نيته في عدم إيذاء الطرف الأخر وبخاصة إذا كان هذا الدفع تلقائيا وسريعال). والأصل أن يكون دفع القسط في موطن المدين به ( المومن له ) ، ولكن جرت العادة على كلى أن مكان الوفاء بالقسط الأول هو موطن المؤمن سواء أكان المركز الرئيسي لشركة التأمين ،أو في مقر فرع الشركة ، أو لدى مندوبها الموكل بالقبض ، ثم يكون دفع الأقساط التالية في

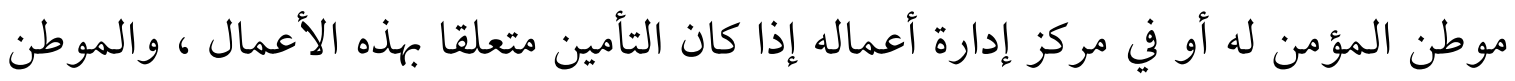
التأميني للمؤمن له هو الموطن الذى ذكره في وثيقة التأمين (o). واذا كان الأصل هو أن الدفع التالي للقسط الأول يكون في موطن المؤمن له إلا أن هذا

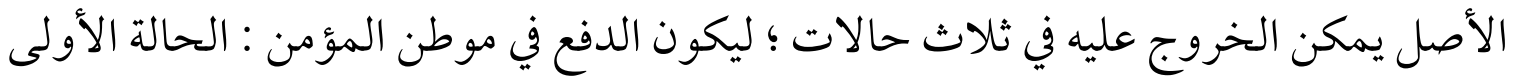

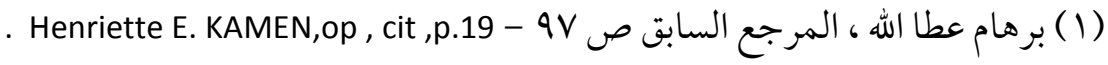

$$
\begin{aligned}
& \text { (Y) المادة Y| | / / Y من تقنين التأمين الفرنسي - المادة } 10 \text { من مشروع وزارة الاقتصاد }
\end{aligned}
$$

(3) Henriette E. Kameni, op , cit ,p.15 and 19

(4) Ibid

(0) السنهوري ، المرجع السابق ص بع 17 - برهام عطا الله ، المرجع السابق ص ع.1 
حينما يجد المؤمن له أن من مصلحته أن يتفق مع المؤمن على أن يكون الدفع في مكان أخر غير موطنه ، وفي هذه الحالة يجب إدراج هذا الشرط ضمن الشروط الخاصة المكتوبة بحروف بارزة بناء على طلب المؤمن له") ، الحالة الثانية فيكون الدفع في موطن المؤمن إذا لم يكن أو لم يعد للمؤمن له موطن في البلد الذى يكون فيه للمؤمن وكلاء ، وذلك الاستثناء الهدف منه منع إرهاق المؤمن ذلك أنه يسعى إلى المؤمن له بطلب القسط عن طريق وكلائه

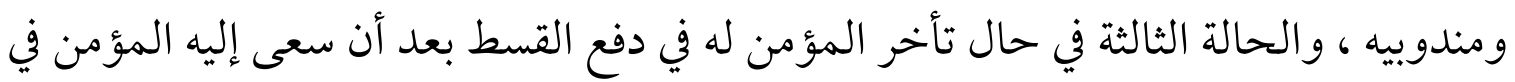
طلبه فيجوز للمؤمن أن يعذر المؤمن له بكتاب موصى عليه بعلم الوصول يرسله إلى آخر موطن معلوم للمؤمن له ومن وقت هذا الإعذار يصبح القسط محمولا لا مطلوبا فيصبح واجب الأداء في مركز إدارة المؤمن (().

هذا ويتعين على المؤمن له دفع مبلغ القسط بالكامل إذا كان القسط هو القسط الوحيد أو يدفع الجزء المستحق في حال تقسيم القسط ليكون شهري ، أو ربع سنوي ، أو نصف لهف

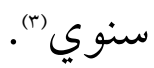

وعادة يتم الدفع نقديا في مقابل استلام إيصال أو مخالصة الدفع ، كما يجوز أن يتم الدفع

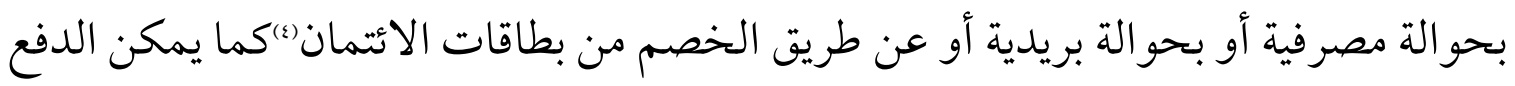
بكمبيالة بشرط قبول المؤمن لهه.

كذلك يمكن أن يتم دفع القسط عن طريق المقاصة وذلك إذا تحقق الخطر قبل أن يدفع

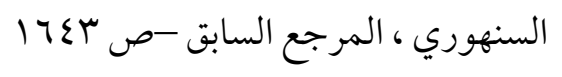

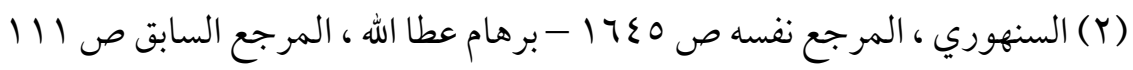

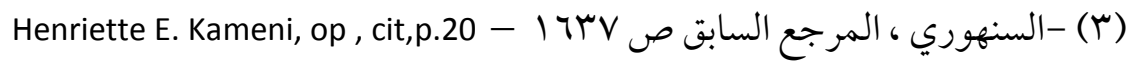
(4) Henriette E. Kameni,op , cit ,p.20

$$
\text { 19£V V السنهوري ، المرجع السابق ص }
$$


المؤمن له القسط المستحق ، فيجوز للمؤمن أن يخصم قيمة مبلغ القسط الذى يجب دفعه وذلك من مبلغ التأمين الذى يستحقه المؤمن له نتيجة تحقق الخطر (1). وإذا كان دفع المؤمن له للقسط هو الذى يخضع شركة التأمين للضمان ويجعل العقد ساري المفعول إلا أن عدم سداد القسط لا يتفق مع طبيعة عقد التأمين ، كما أنه يعد عنتا بالمؤمن لذلك أعطى المشرع المؤمن ضمانته في مو اجهة المؤمن له المقصر في سداد القسط حيث رتب على عدم سداد القسط إمكانية تعليق الضمان وكذلك الإمكانية في إنهاء العقد (r). فعدم أداء المؤمن له لأحد الأقساط في ميعاد استحقاقه يجيز للمؤمن في غضون عشرة أيام من تاريخ استحقاق القسط أن يعذر المؤمن له بكتاب مصحوب بعلم الوصول يرسله له في أخر موطن معلوم ويبين فيه أنه مرسل للإعذار ويذكره بتاريخ استحقاق القسط وبالنتائج المترتبة على هذا الإعذار وهي كون القسط مستحق الأداء في مركز إدارة المؤمن ، فإذا لم يقم المؤمن له بأداء القسط المستحق رغم إعذاره فإن عقد التأمين يوقف سريانه بمجرد مرور ثلاثين يوما من تاريخ إرسال الإعذار ( التي تحسب من اليوم التالي للإرسال ) ، وهذا الوقف والتعليق لعقد التأمين يتم تلقائيا ، وبمجرد حدوثه لم يعد المؤمن يغطى المخاطر المؤمنة ، وفي حال حدوث الخسارة فلن يتم تعويض المؤمن له وذلك ما لم يكن حدوث الخسارة بعد إصلاح العقد ودفع جميع مصاريف المؤمن" ويجب أن ننوه إلى أن وقف سريان العقد يكون بالنسبة إلى التزامات المؤمن فقط ، أما

(1) فاذا كان القسط السنوي مقسم إلى أجزاء يدفع كل جزء مقدما كل ستة شهور أو ثلاثة شهور أو كل شهر فإن ذلك طريقا لتيسير الدفع على المؤمن له ويبقى القسط قسطا سنويا بحيث إذا تحقق الخطر في أول السنة كان على المؤمن له أن يدفع جميع أجزاء القسط بأكملها وتخصم من مبلغ التأمين.

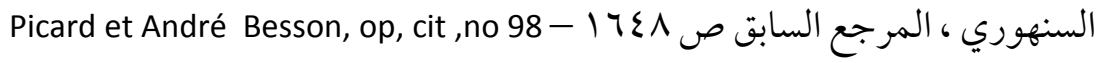

(2) Henriette E. Kameni, op , cit , p.20.

(3) Lamy assurances, 2005, op. Cit. p. 44. 
بالنسبة لالتزامات المؤمن له فتبقى ويظل ملتزما بدفع قسط التأمين طوال مدة وقف العقد (1) لا يتحلل من التزامه إلا إذا فسخ العقد .

\section{ثانيا : الالتزام بإعلان المؤمن بالظروف الجديدة التي تفاقم الخطر .}

عقد التأمن عقد زمنى يستمر تنفيذه مع الزمن ؛ لذلك فإنه ينشى التزامات على عاتق كل

طرف من أطراف العقد ، ويجب على كل طرف احترامها بشكل حتمي ()و المؤمن له بقدر ما هو معنى فإن عليه التزامات خلال سريان العقد المبرم مع شركة التأمين ويجب أن يمتثل لها بحسن نية ، ولا يقتصر إظهاره لحسن النية على التزامه بالإدلاء بالمعلومات المتعلقة بالخطر عند إبرام عقد التأمين ، بل يجب عليه أن يكون مخلصا وعادلا لشركة التأمين طوال فترة العقد وليس عند تكوين العقد وفقط ، ويتم تحليل حسن نيته في هذه المرحلة على أنه احترام

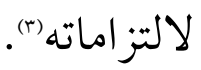

فبمجرد التوقيع على عقد التأمين ، يوافق المؤمن له على الخضوع لمبدأ الولاء وحسن النية وبهذه الحقيقة يفقد حريته في الحفاظ على أسراره ، وليس كل أسراره ولكن تلك التي

و هذه الأحكام لا تطبق في القانون الفرنسي على التأمين على الحياة وذلك وفقا للمادة r| / / / من تقنين التأمين الفرنسي حيث لا يمكن وقف تنفيذ العقد لعدم دفع القسط ، فليس هاك جزاء لعدم دفع القسط بعد استيفاء الإجراءات المقررة بموجب الإعذار بالدفع وليس هناك اختيارا أمام المؤمن إلا فسخ العقد فستخا

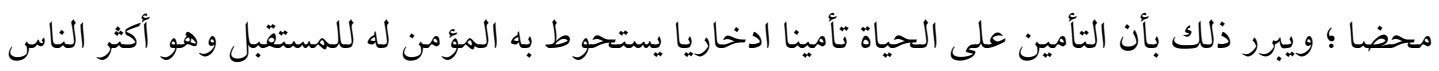

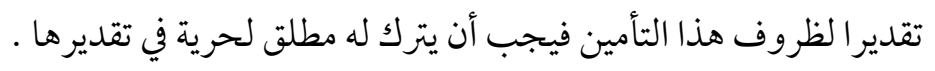

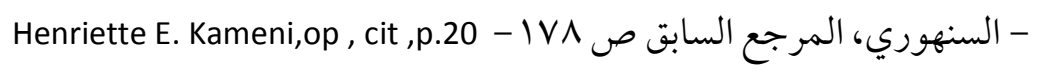
أما في مصر فإن المؤمن له يبقى ملتزما بدفع الأقساط ويجوز أن يطالبه المؤمن بالدفع قضاء الا إذا اختار

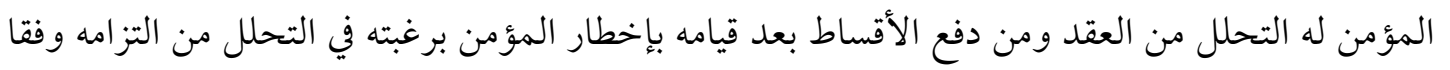

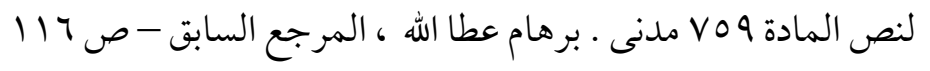

(2) Christianne Dubreuil, op , cit ,p.1101

(3) Henriette E. Kameni,op , cit ,p24 
تكون ذات أهمية خاصة للمؤمن والتي تسمح للأخير بتقييم المخاطر (1)في حال حدوث ظروف جديدة تعدلها.

وهكذا فإن إثبات المؤمن له ولاءه لشريكه في عقد التأمين يوجب عليه الإعلان عن أية

ظروف جديدة يترتب عليها تفاقم الخطر أو إنشاء مخاطر جديدة خلال فترة تنفيذ العقد"..

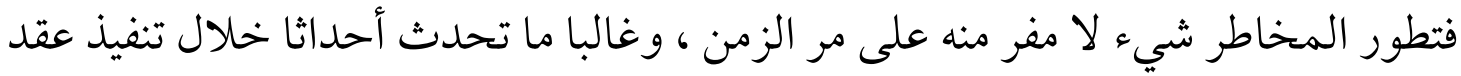

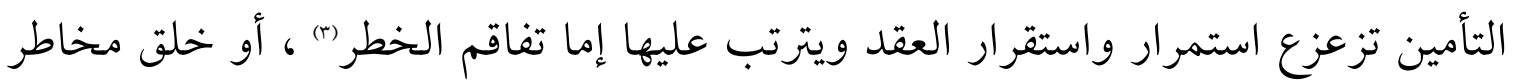
جديدة مما يجعل الإعلان الأولى المتعلق بالمخاطر غير مجد بالنسبة لشركة التأمين ، والتي أعطت موافقتها على مخاطر محددة ، وبالتالي يكون من الطبيعي السماح لشركة التأمين

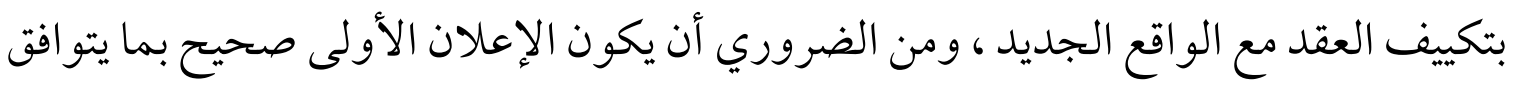
مع متطلبات قانون التأمين و وإلا فلا يمكن تحميله المسئولية وفرض عقوبات عليه لعدم

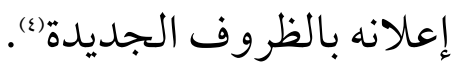

ويعد بيان المخاطر الأولى هاما جدا للمؤمن له ؛ ليتمكن من إعلان الظروف الجديدة بطريقة سليمة ، لذلك يجب على المؤمن له الاحتفاظ بنسخة من الاستبيان وإجاباته ؛ حتى يدرك التطورات التي تجعل ظروف الخطر واجبة الإعلان أثناء سريان عقد التأمين. وإذا كان الأمر متروكا للمؤمن له ليحكم على ما إذا كان يجب الإعلان عن الظروف

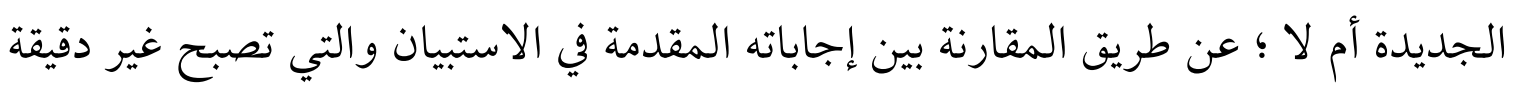

(1) Camila HABOUBI, op ,cit, no 29

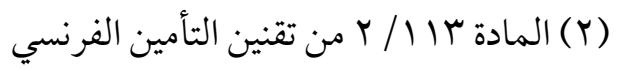

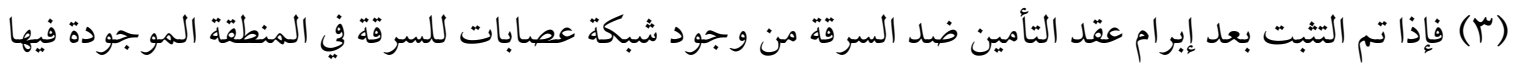

$$
\text { الممتلكات المؤمن المشمولة بالضمان فهذا يعد تفاقما للمخاطر }
$$

Fulbert Youssouf . Les obligation de l'assuré en matiere d'assurances dommages Universite d'Abomey-Calavi(Benin) master droit des affaires et fiscalité 2003, p.10

(4) Cass . 2e civ., 22 janv. 2009, n 08-10294 et 07-20378, RGDA 2009, p. 98, note L. Mayaux 
وعفا عليها الزمن بعد تغير المخاطر ، إلا أنه في الحقيقة فإن المؤمن له كثيرا ما يسئ فهم ما يجب إعلانه وهذا ما جعل محكمة النقض الفرنسية ترى ضرورة أن يلفت المؤمن انتباه المؤمن له بموجب بند في عقد التأمين يشير إلى وجود التزام بالإبلاغ عن حالات التفاقم ، وخلاف ذلك لا يمكن اعتبار معرفته بهذا الأمر ، مما يستبعد بالضرورة الطبيعة الاحتيالية لإغفاله ، وبالتالي استبعاد إعلان البطلان على أساس المادة ب| / / من تقنين التأمين ؛ لذلك ، فإن عدم وجود بند يوجه بوضوح انتباه المؤمن له إلى وجود التزامات الإبلاغ الخاصة به يمكن أن يستخدمه قضاة المحاكمة ، الذين يعتبر تقييمهم سياديًا ، لاعتبار عدم إثبات سوء النية من المؤمن له الذى يعد ضروريا لتطبيق البطلان الوارد بالمادة س | / / N". كما يمكن للمؤمن أن يلفت انتباه المؤمن له بضرورة الإبلاغ عن الظروف الجديدة وذلك من خلال التز امه بتقديمه المعلومات و المشورة.(1).

و إذا كان الالتزام بالإعلان الأولى للخطر يقوم في كل أنواع التأمين إلا أن الالتزام بالإعلان عن تفاقم الخطر غير مطلوب في حالة التأمين على الحياة(1)؛ وذلك لأن الهدف الأساسي في هذا النوع من التأمين هو التأمين من خطر الموت أو البقاء على قيد الحياة والتي لا يمكن إلا أن تتفاقم أو تتغير مع مرور الوقت وهذا أمر مفترض العلم به لشركة التأمين(s) تأخذ ذلك بعين الاعتبار عند تحديد قيمة القسط (م) كما أن شركات التأمين يمكن لها أن تمنع بعض حالات التفاقم المحتملة عن طريق الشرط الصريح على استبعاد بعض المخاطر من نطاق

(1)- Cass. crim., 9 sept. 2014, $\mathrm{n}^{\circ} 13-84198$ et $\mathrm{n}^{\circ} 13-85432$, RGDA 2014, $\mathrm{n}^{\circ} 11, \mathrm{p} .548$, note M. Asselain.

(2) Cass. 1re civ., 17 mai 1982, n 81-11112 ; Cass. 1re civ., 1er févr. 2000, n 97-15206, Resp. civ. Et assur. 2000, comm. 130 ; Cass. 1re civ., 14 nov. 2001, n 98-21878. (r) المادة r| / / / من تقنين التأمين الفرنسي J. BONNARD, Droit et pratique des assurances, DELMAS, 1re éd. Paris 1997,p.5a6

(4) Christianne Dubreuil, op , cit , p.1101

(5) Henriette E. Kameni,op , cit ,p.29 
التأمين على الحياة كالانتحار والموت في الحرب أو في الطير ان أو تنفيذا لحكم الاعدام").

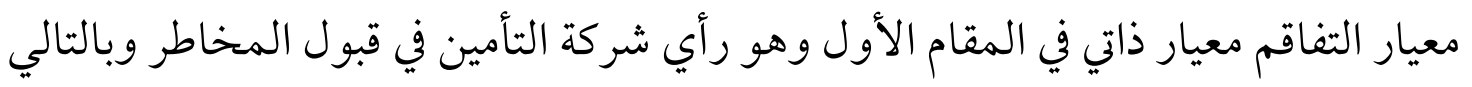
فإن الظرف الجديد والمشدد هو الظرف الذى لو كان المؤمن له قد أعلنه وقت التعاقد لكان

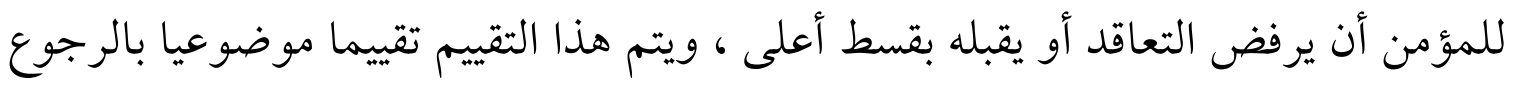

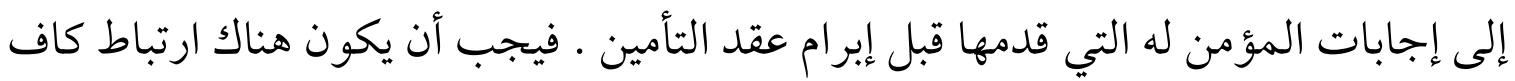

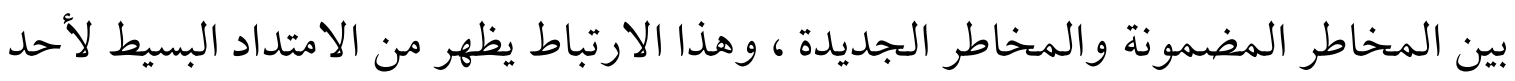
عناصر الخطر المضمون من البداية ، فبناء أو شراء عقار جديد للمؤمن له بجوار المبنى

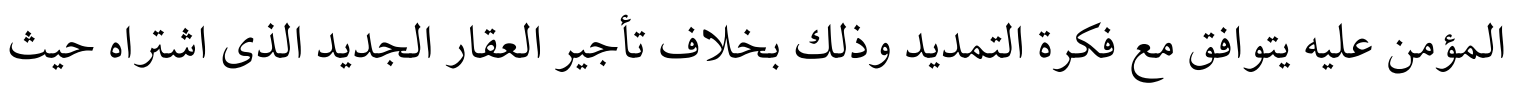
يكون هناك مخاطر بعيدة جداعن المخاطر المضمونة).". ومسألة تفاقم الخطر هنا تثير تساؤلا مهما عن مدى التزام المؤمن له بالإفصاح والإعلان

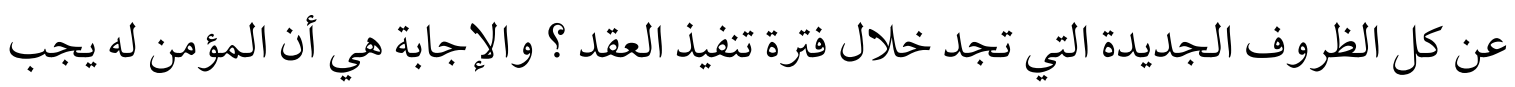

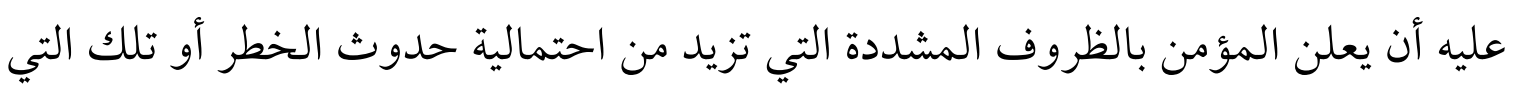

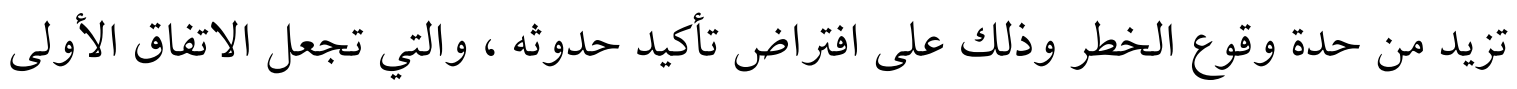
غير موجود على أرض الواقع حيث تغيرت الظروف التي تشكل أساس التأمين (مأما زيادة المخاطر التي ليس لها أي آثار سلبية على عقد التأمين فلا إلزام على المؤمن له بإخطار

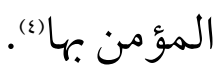
فإذا ما كان الشخص يستخدم سيارته من وقت لأخر في عطلة نهاية الأسبوع ، مع ذلك فإن

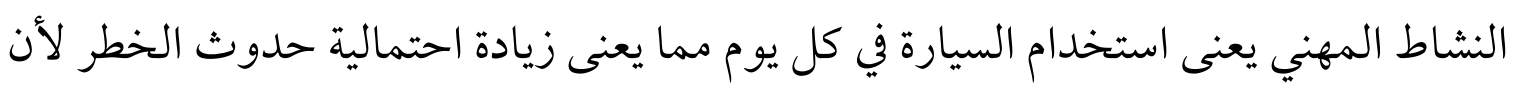

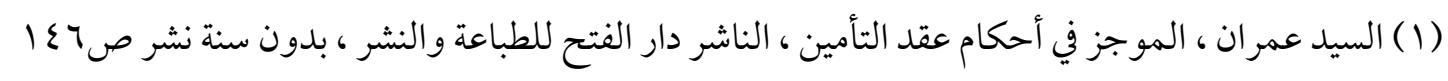
(2) Cass. 1re civ., 15 juin 1999, no 97-17426, RGDA 2000, p. 71, note J. Kullmann

(3) J. BONNARD, op, cit , p.140a141

(4) Yiqing Yang, op , cit , p.296 
عدد الكيلو مترات المقطوعة أصبح أكبر بكثير (1).

كذلك في بعض الأحيان تؤدى الظروف المتغيرة إلى زيادة حدة المخاطر بما يعنى أنه ينشأ

عنها زيادة في حجم المطالبات التي تثقل كاهل شركة التأمين ماليا كالتأمين ضد الحريق ، فإذا كان الحريق ناجما عن طرف ثالث فإن شركة التأمين سوف تحل محل المؤمن له وسيكون لديها مطالبة ضد هذا الشخص ، ولكن إذا أجر المؤمن له شقته لصديق وحدث الحريق فالغالب أنه سوف يتخلى عن كل حق في الرجوع ضده ، وهذا التنازل قبل حدوث الخسارة سيكون قابلا للتنفيذ ضد شركة التأمين ، وبالتالي لن يكون لها حق الرجوع على صديق المؤمن له وبالتالي سوف تتحمل شركة التأمين زيادة في نفقات التعويض للمؤمن له ، وهذا الظرف - التعاقد - إذا كان قد عرف أثناء إبرام العقد فإنه سيقود إما إلى رفض التعاقد أو التعاقد مع رفع قيمة القسط . هذه الظروف الجديدة التي يجب إعلانها يمكن أن تكون ظروفا موضوعية أو ظروفا ذاتية

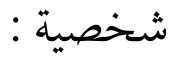
فيما يتعلق بالظروف الموضوعية وهي تلك التي تتعلق بجوهر العقد وموضوعه مثل تحول المبنى في تأمين الأشياء من النشاط السكنى إلى النشاط الصناعي أو التجاري كذلك تغيير حالة المبنى ، وطبيعة مواد البناء المستخدمة فيه ، وفي تأمين المسئولية قد يتفاقم الخطر بتغيير الشخص المؤمن له مهنته بمهنة جديدة أو أي تعديل يتعلق بحياته الاجتماعية أو المهنية أو الخاصة). ().

أما بالنسبة للظروف الذاتية فهي تلك التي تتعلق بشخص المؤمن له وبأي تغيير يؤثر على شخصه ؛ فهذه الظروف تتعلق بأخلاق المؤمن له وتصرفاته العامة وسلوكه بصفة خاصة في

(1) Cass. 1re civ., 22 juill. 1986, $\mathrm{n}^{\circ} 84-17413$, RGAT 1986, p. 560, note F. Chapuisat

(2) Henriette E. Kameni,op , cit ,p.29 
مجال التأمين"(1)ومن أمثلة ذلك قيام المؤمن له بالتعرض لخسارة نفس المخاطر وكذلك

$$
\text { الإدانات السابقة في حوادث السيار ات . }
$$

واقع الأمر أن هذه الظروف هجينية نوعا ما ؛ لأنها تسمح لنا بإعطاء المعلومات عن المخاطر كما أنها تعطينا أيضا معلومات عن أخلاقيات المؤمن له وسلو كياته (r). يجب أن تكون زيادة المخاطر زيادة دائمة ، فالزوال التلقائي يجعل التغيير الذى تم غير مجد ومن الضروري التمييز بين الزيادات المؤقتة للمخاطر وتغيرات الاستخدام على سبيل المثال فإن حادث السيارة العرضي بسبب فشل الفرامل لا يرجع إلى زيادة المخاطر التي لم

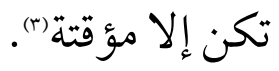

كذلك الحال فإنه إذا كانت زيادة المخاطر متوقعة فإنه لا يمكن القول بزيادة المخاطر التي يجب على المؤمن له أن يخطر المؤمن بها ؛ وذلك لأن عملية تحديد القسط يتم ترتيبها بناء على السلوك المتوقع وكلما كان هناك توقع لزيادة الخطر كلما زاد قسط التأمين ؛ لذلك لا يمكن القول بأن السلوك المتوقع بوضوح يزيد من الخطر، فعلى سبيل المثال في حال التأمين على السفن تعتبر معرفة منطقة عمليات السفينة مهمة في تحديد سعر قسط التأمين ، وزيادة المخاطر بدخول السفينة منطقة عمليات غير متوقعة ؛ كدخولها منطقة حرب يعد مهما لشركة التأمين ويجب إعلانها بذلك. الأهم من ذلك يجب أن تكون زيادة المخاطر كبيرة وليس مجرد زيادة في المخاطر (s)لذلك نجد أنه في كثير من الأحيان تبقى شركة التأمين على العقد كما هو دون زيادة في قيمة قسط

(2) Henriette E. Kameni, op , cit ,p.29

(3) Yiqing Yang, op , cit ,p. 298

(4) Ibid, p.299. 
التأمين وذلك لأن الزيادة في المخاطر كانت في حدها الأدنى (1). كذلك يجب أن يكون لزيادة المخاطر التأثير الحاسم على قبول شركة التأمين لتأمين المخاطر وتجديد شروط العقد أو الإنهاء ؛ لذلك غير مطلوب من المؤمن له تقديم إشعارا للشركة إذا كانت درجة الأهمية غير كافية للتأثير في قرار شركة التأمين في قبول المخاطر. وقت الإعلان عن تفاقم الخطر. يجب على المؤمن له أن يعلن المؤمن بالظروف الجديدة التي أدت إلى تفاقم الخطر في الوقت المناسب ؛ ذلك أن هذا الإعلان يتيح لشركة التأمين اختيار استمرارية عقد التأمين مع مراعاة بعض التعديلات المتعلقة بالقسط أو المساهمة المستحقة الدفع أو إنهاء العقد. بالنسبة للقانون المصري فإنه لم يحدد شكلا أو وسيلة للإعلان عن هذه الظروف أو المدة الواجب القيام بالإعلان خلالها ؛ لذلك فإن الإعلان يجب أن يتم خلال المدة المعقولة التي يقوم القاضى بتقديرها عند النزاع إذا خلت وثيقة التأمين من تحديدهاد). كما أنه من الحكمة وجود دليل أو وسيلة إثبات بيد المؤمن له ؛ لذا من الأفضل أن يكون الإعلان كتابيا عن طريق خطاب مسجل بعلم الوصول حتى يكون له تأثيره على تقدم العقد وذلك طالما أن المؤمن سوف يستجيب لهذا الإعلان ويرد عليه كتابيا".

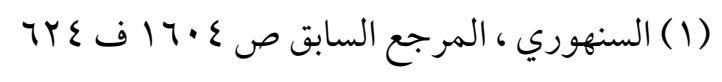

ومع ذلك نرى عكس ذلك في بعض الأحكام القضائية التي ترى أنه يجب على المؤمن له أن يصرح بأي تعديل في

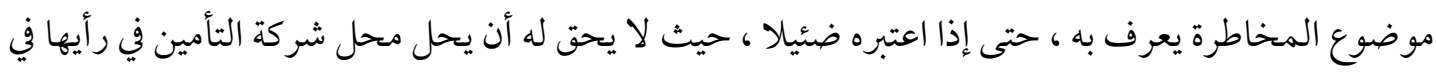

$$
\text { تحمل الخطر. }
$$

CA Paris, 14 févr. 1986 : Gaz. Pal, 1987, 1, somme. p. 109

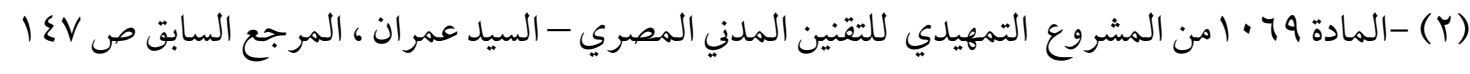

(3) Henriette E. Kameni, op , cit ,p.29 
وهذا عين ما فعله القانون الفرنسي"حيث يجب على المؤمن له أن يعلن المؤمن بموجب خطاب مسجل بعلم الوصول ، أو بالبريد الإلكتروني(") المسجل بهذه الظروف الجديدة في خلال خمسة عشر يوما من إدراكه وعلمه بهذه الظروف ، وهذه المدة تعتبر مدة كافية للوفاء بهذا الالتزام بشكل صحيح ، ويعتبر الإعلان قد تم حتى إذا تم استلامه من قبل شركة التأمين

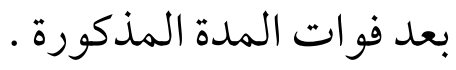

ولكن يجب أن نفرق بين ما إذا كان التفاقم راجعا إلى فعل المؤمن له أو إذا ما كان لا يد له

$$
\text { في حدوثه : - 20 - n }
$$

فإذا كان التفاقم راجعا إلى فعل المؤمن له ؛ كأن يكون هو الذى وضع المواد البترولية القابلة للاشتعال في مخزن منزله المؤمن عليه ضد الحريق ، أو يكون قد غير استعمال سيارته من الاستعمال الخاص إلى الاستعمال المهني ، في هذه الحالة يتعين على المؤمن له أن يعلن المؤمن بما ينوى فعله قبل القيام به والمقصد من القيام بذلك الإعلان ليس الحصول على إذن المؤمن للقيام بالعمل ولكن الهدف من ذلك حتى يستطيع المؤمن إعادة حساباتهات.

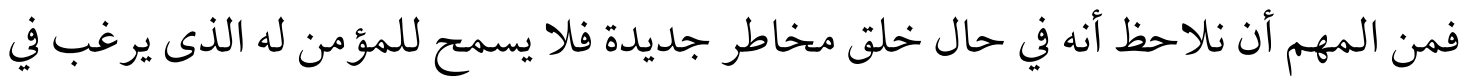
الاستفادة بشكل أفضل بعقد التأمين عن طريق زيادة المخاطر ، أو إضافة مخاطر جديدة إلا في في حالة وجود إعلان مسبق لهذه المخاطر لشركة التأمين والتي يتعين عليها دراسة طلب

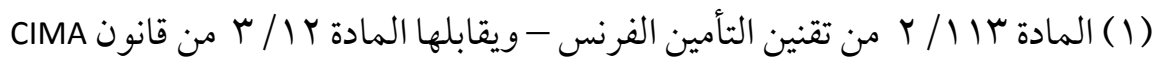

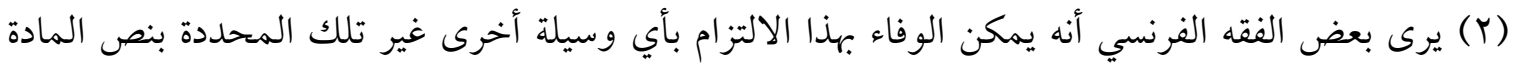

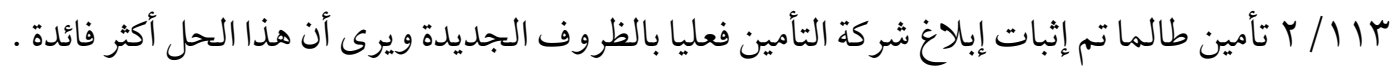
FAIVRE- ROCHEX et G. COURTIEU, le droit du contrat d'assurance terrestre, LGDJ, 1998 n¹-234 p.115 Lamy assurance 2008, p 153

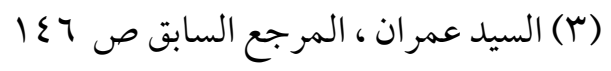




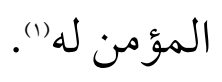

أما إذا كان تفاقم الخطر غير راجع إلى فعل المؤمن له ؛ كما لو أقيم بجانب المنزل المؤمن عليه ضد الحريق مخزنا للمواد البترولية القابلة للاشتعال ، في هذه الحالة فإن الإعلان بتفاقم الخطر يجب أن يتم في المواعيد المقررة قانونا وذلك من اللحظة التي علم فيها المؤمن له بالظروف المشددة ، وفي حال عدم علمه فلا التزام عليه (") . من ناحية أخرى فإن مجرد معرفة المخاطر الجديدة من قبل شركة التأمين لا يحرم المؤمن له من الإعلان ؛ حيث يمكن للشركة أن تستفيد من العقوبات المقررة لعدم الإعلان بالمخاطر الجديدة كما أن هناك مسافة بين الالتزام بالإعلام في قانون التأمين والالتزام بالإعلام في القانون المدني وذلك لأن الالتزام بالإعلام في الأخير مشروط بجهل الشريك المتعاقد ويختفي عندما يثبت معرفته (r). الأثر المترتب على تنفيذ الإعلان بتفاقم الخطر . بمجرد أن يتم الإعلان في الوقت المناسب عن الظروف الجديدة التي تفاقم الخطر فإن المؤمن له يكون في وضع قانوني سليم ويبقى عقد التأمين ساريا وتبقى المخاطر مضمونة ومغطاة تغطية تأمينية مؤقتة) لحين قيام المؤمن بفحص الوضع الجديد وتحديد موقفه من

(1) Henriette E. Kameni,op , cit ,p.30

في القانون الإنجليزي إذا كان التغيير يصل إلى أنه يشكل خطرا جديدا فهنا يجب التعامل مع هذه المخاطر الجديدة في سياسية تأمينية جديدة ويعتبر هذا الإعلان بمثابة أحد واجبات المؤمن له في المر حلة قبل التعاقدية. Yiqing Yang , op , cit ,p.306

$$
\begin{aligned}
& \text { Yiqing Yang , op , cit ,p.306 - I ₹V السيد عمر ان ، المرجع السابق ص (Y) } \\
& \text { (Y) المادة r / / / / من القانون المدني الفرنسي }
\end{aligned}
$$

(ع) من المسلم به أن هذه التغطية المؤقتة تسئ إلى تقنية التأمين ، ولا سيما مبدأ التناسب بين القسط والمخاطر

$$
\text { المضمونة ، ومع ذلك فهي ضرورية لأمن وحماية حامل الوثيقة . }
$$


الظروف الجديدة باختيار أحد الخيارات المتاحة له وفي هذه الحالة إذا تحقق الخطر خلال هذه الفترة استحق المؤمن له تعويضا كاملا حتى ولو كانت الظروف الجديدة هي التي تسببت

$$
\text { في وقوع الحادث المؤمن منه" (1). }
$$

والخيارات المتاحة للمؤمن إبان إعلانه بتفاقم الخطر فهي: إما الإبقاء على العقد كما هو ،

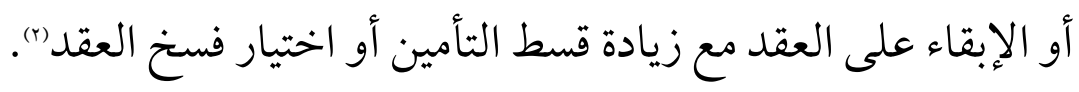

$$
\begin{aligned}
& \text { أ- الإبقاء على العقد. }
\end{aligned}
$$

فقد يوافق المؤمن على الإبقاء على العقد كما هو دون أي زيادة في قيمة القسط ، وعادة ما

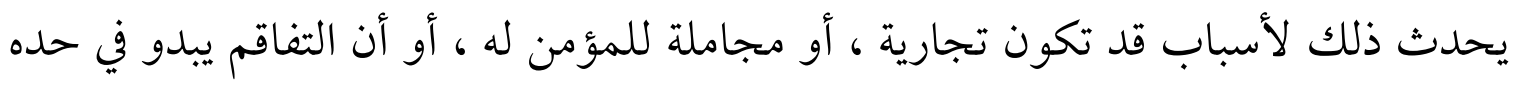
الأدنى (r)وهذه الموافقة قد تتم صراحة عندما تظهر شركة التأمين قبولها مواصلة تحصيل

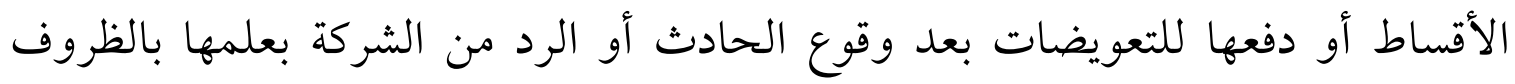
الجديدة ، وفي مثل هذه الحالات لا تستطيع شركة التأمين الاعتماد على تفاقم الخطر مرة

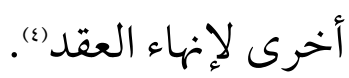

وقد يكون اختيار الشركة الإبقاء على العقد ضمنيا بالصمت ؛ لذلك إذا قامت الشركة بتحصيل الأقساط كما هي بسعرها الأولى فهي تو افق على الإبقاء على العقد كما هو بشروطه الأولية() يضاف إلى ذلك أن المؤمن إذا طلب من المؤمن له تعديل القسط ولم يو افق الأخير على هذا التعديل فلا يعنى هذا إنهاء العقد ، إنما يجب أن يقرر المؤمن الإبقاء على العقد

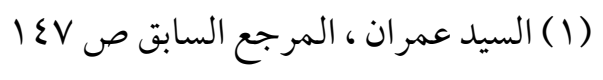

(2) Christianne Dubreuil , op , cit ,p.1101 - Yiqing Yang , op , cit ,p.307

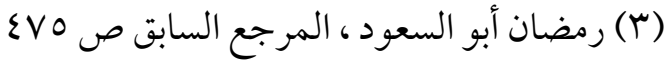

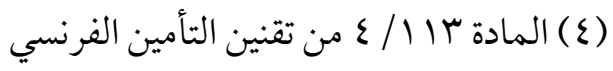

(5) Cass. 1re civ., 8 juill. 2003, Resp. civ. et assur. 2003, comm. 279, RGDA 2003, p. 675, note A. Favre Rochex 
أو الفسخ ، فإذ لم يختر الفسخ خلال المدة المعقولة فإن سكوته يعتبر قبو لا منه بالإبقاء على العقد دون زيادة القسط "(ال.

$$
\text { ب- تعديل العقد }
$$

قد يرى المؤمن بعد إخطاره بتفاقم الخطر إمكانية المحافظة على التوازن العقدي ، وذلك بطلبه زيادة قسط التأمين ، وفي هذه الحالة التعديل يعتمد على موافقة المؤمن له والذى يجب عليه الموافقة على التعديل كتابة.

أما الرفض من قبل المؤمن له على التعديل فيمكن أن يكون صراحة ، كما يمكن أن يكون ضمنيا وذلك إذا لم يستجب إلى طلب التعديل في خلال ثلاثين يوما من اقتراح التعديل وفي هذه الحالة سيتمكن المؤمن من إنهاء العقد بدون تعويض. في الو اقع هذا الحل الأخير له متطلبات شكلية ، فمن الضروري أن يتم إبلاغ المؤمن له عن نتيجة رفضه زيادة قسط التأمين وذلك من خلال الإشعار الذى الذي ترسله له شركة التأمين باقتراح زيادة القسط على أن يتضمن هذا الاقتراح ضرورة الإشارة إلى أنه في حال رفضه لتعديل القسط فإنه سيتم إنهاء العقدل(r). وحتى لا تكون مسألة قبول الزيادة أو رفضها متو قفا على إرادة المؤمن له أو حتى لا يفسر بأنه قبول أو رفض فإن من مصلحة المؤمن أن يحدد مدة للمؤمن له لقبول أو رفض الاقتراح بزيادة القسط ويكون العقد مفسو خا من تلقاء نفسه حال مضى تلك المدة .

$$
\text { ج- فسخ العقد }
$$

للمؤمن طلب فسخ العقد وذلك إذا وجد أن استمرار عقد التأمين بعد تفاقم الخطر يؤدى إلى اختلال التوازن العقدي ويتجاوز حدود ما وافق عليه المؤمن لتحمل المسئولية.

(1) Picard et André Besson, op, cit , p.129, no 74

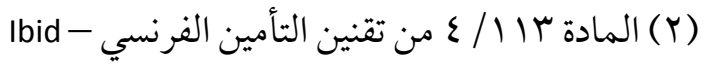


فيجب على المؤمن أن يخطر المؤمن له بفسخ العقد ، وفي هذه الحالة فإن فسخ عقد التأمين لن يكون نافذا إلا بعد مرور عشرة أيام من تاريخ استلام الإخطار بالفسخ ، وفي هذه الحالة يتعين على المؤمن أن يرد للمؤمن له جزءا من القسط المدفوع مقدما وذلك عن الفترة التي تلى تاريخ الفسخ (1)باعتبار أن هذه الفترة غير مغطاة بعقد التأمين والمؤمن له غير مدين بالقسط

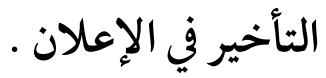

إذا لم يقم المؤمن له بإعلان المؤمن بهذه الظروف التي تؤدى إلى تفاقم الخطر ، وذلك رغم علمه بها ، ففي هذه الحالة المؤمن له لا يثبت سوء نيته فحسب بل أنه يعد مفتقر الأحد التزاماته القانونية التي تبرر ضياع حقه في التعويض مع احتفاظ المؤمن بأقساط التأمين (r). عندما يقوم المؤمن له بإعلان المؤمن بتفاقم الخطر ولكن بعد الميعاد المحدد قانونا فإن المؤمن يمكن أن يتمسك بهذا التأخير كسبب من أسباب مصادرة الضمان إضافة إلى احتفاظه بأقساط التأمين بشرط أن يكون قد ذكر ذلك في وثيقة التأمين بأحرف بارزة وواضحة للغاية ويقدم مبرره بتكبده خسارة نتيجة ذلك التأخير (s) بالتالي فإن فإن أي إدراج للمصادرة في النظام الأساسي أو في اللو ائح الداخلية لشركة التأمين أمر غير قانوني والواقع أن عقوبة المصادرة في حالة الإعلان المتأخر عن المخاطر تظهر بعض التناقضات مما يجعل هذه العقوبة غير مناسبة ؛ وذلك لأنه سيكون من الصعب على شركة التأمين إثبات الضرر بسبب التأخير ، بالإضافة إلى أن المصادرة هدفها عقاب المشترك دون أن تنظر لأسبابه

(2) Picard et André Besson,op,cit,p.129,no 74

(3) J. BONNARD, op,cit , p.148

(4) Henriette E. Kameni, op , cit ,p.30

(5) op , cit , p.40 Fulbert Youssou 
ودوافعه ( حسن النية أو سوء النية ) ، كما أنه ينشأ سؤ الا هاما عن ماهية خسارة شركة التأمين بسبب التأخير البسيط واستمرار سريان العقد دون حصول شركة التأمين على علاوة القسط الاضافية والتي تعتبر بسيطة بالنسبة لباقي تكلفة العقد ، خاصة وأن ضرر شركة التأمين يكون مرتبط فقط بوجود مطالبة ، أما في حال غياب المطالبة فلا وجود للضرر كما أن عقوبة المصادرة أشد بكثير من العقوبة المطبقة المطبقة على المؤمن له حسن النية الذى يخفق إخفاقا تاما في أداء الإعلان ، حيث سيظل يتلقى تعويضا حتى ولو كان منخفضا'." ثالثا: التزام المؤمن له بالإعلان عن التأمين المتعدد كمظهر من مظاهر حسن النية . إضافة إلى ما سبق من التزامات تقع على عاتق المؤمن له ، فإنه ملتزم كذلك بأن يظهر حسن نيته تجاه المؤمن بإخباره بأي توقيع من قبله على أي عقد تأمين أخر لضمان نفس المخاطر التي يضمنها المؤمن ، فمن خلال قيامه بذلك فإنه يدلل على صدق نواياه واحترامه لأحكام عقد التأمين (r) - إن. وفي هذه الحالة نحن بصد تعدد لعقود التأمين والتي توجد إذا أمن المؤمن له لدى اثنين من شركات التأمين أو أكثر على شيء واحد ولمصلحة واحدة ضد نفس الخطر (r). وهذا التعدد لعقود التأمين يختلف عن بعض أنواع التأمين المشابهة له مثل التأمين الزائد أو المفرط وهو التأمين الذى يكون نتيجة عقد واحد بمبلغ يزيد على قيمة الشيء المؤمن عليه حيث يصرح المؤمن له بقيمة للشيء المؤمن عليه أعلى من القيمة الحقيقية للشيء ، وهذا الإفراط في التامين يشعر بالاحتيال ؛ لذلك فإن النصوص القانونية تميز بين التأمين

(2) Henriette E. Kameni, op , cit , p.28 


$$
\text { الزائد الاحتيالي والتأمين الزائد غير الاحتيالي". }
$$

أما النوع الثاني من التأمين الذى يتشابه مع التأمين المتعدد فهو التأمين المشترك الذى ئ ئ يوافق فيه العديد من شركات التأمين على تغطية نفس الخطأ المشترك عن طريق سياسة جماعية وتسمى الشركة التي تتولى تنسيق المعاملة بالشركة الرائدة(r). فني بعض الأحيان يكون حجم الخطر كبيرا جدا على شركة تأمين واحدة فلا تستطيع وحدها تحمل فقدان سفينه أو مجمع صناعي ، فهنا يتم تقسيم المشاركة في التأمين على أساس توزيع تدخل كل شركه تأمين عند مستوى معين ، فيكون تدخل الشركة الأولى عند حدوث مطالبات تقدر مثلا بمليون جنية ، على أن يتم تدخل الشركة الثانية إذا كانت المطالبات قيمتها مليون جنيه الى عشرة ملايين ، ثم يكون تدخل شركة التأمين الثالثة عند

$$
\text { وجود مطالبات تزيد على عشرة ملايين ......وهكذا . ه }
$$

التأمين التراكمي يقترب من التأمين الزائد حيث تكون قيمة المبالغ المؤمن عليها من خلال العديد من عقود التأمين أكبر من القيمة الحقيقية للشيء. بالتالي فإنه في حال حدوث فقدان للشيء فإن كل شركة من شركات التأمين ستكون ملزمه بدفع التعويض ، وعلى ذلك سيكون للمؤمن له مصلحة في حدوث الحادث ؛ وذلك لأن قيمة الضمانات التي سيتقاضاها من شركات التأمين المتعددة سيتجاوز معا القيمة الحقيقية وحيث إن الغرض الأساسي من التأمين هو التعويض وليس الربح لذلك يمتنع على

(1) Beira Ehi Marc, Les Assurances Cumulatives, These, Universite De Nice- Faculte De Droitet Dessciences Economiques,1986 p.28

حيث يشيرا إلى أن الشركة الرائدة هي التي تسيطر على Picard et André Besson, op, cit , p.214,no 340 (r) تاريخ نفاذ العقد وهى التي تقبض القسط الأول بالكامل 
حاملي الوثائق الاشتر اك في العديد من سياسات التأمين من أجل تحقيق الربح (1). فعقد التأمين لا يمكن أن يكون سببا للإثراء بلا سبب ، والمؤمن له لا يستطيع تحت أي ذريعة أو سبب المطالبة أو تلقى تعويضا أكبر من القيمة الحقيقية للخسارة التي تعرض لها ()وهذا المبدأ مقرر حماية للنظام العام والأخلاق"). ففيما يتعلق بحماية النظام العام والأخلاق فإنه من السهل إدراك أن التأمين التراكمي سيكون أحد أخطر الهجمات على مبدأ التعويض ، حيث يخشى أن يحصل المؤمن له في حال المطالبة وعن طريق الجمع بين مختلف التعويضات الناتجة عن العقود المختلفة على مبالغ أعلى بكثير من قيمة الضرر الذى حدث (s). ورغبة من المشرع في الحفاظ على النظام العام والأخلاق ، و الحفاظ على مبدأ حسن النية في عقد التأمين والذى يهدف إلى الحفاظ على المصالح المشتركة للمؤمن له وشركات التأمين وكذلك الحفاظ على وظيفة التعويض الحقيقي الذى تقوم به شركات التأمين ، فإن المشرع الفرنسي ألزم المؤمن له الذى يقوم بالعديد من عمليات التأمين على نفس الخطر عن نفس الفترة الزمنية بأن يجعل عقود التأمين هذه معروفة لشركات التأمين المختلفة (o). يجب أن يتم نقل هذه المعرفة المتعلقة بعقود التأمين مباشرة بعد الاشتراك في عقد التأمين الجديد ،وذلك بالنسبة لشركات التأمين السابقة وذلك باستخدام أي وسيلة مكتوبة ؛ كخطاب مسجل بعلم الوصول ـأما بالنسبة لشركة التأمين الجديدة فيجب أن يكون الإعلان في وقت الاشتراك في وثيقة التأمين الجديدة(1) ، فمن الضروري أن تعرف شركة التأمين اسم شركات

(1) Beira Ehi Marc, op , cit ,p.28

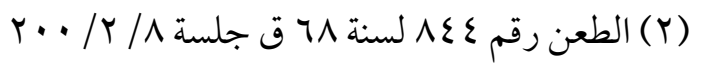

(3) Beira Ehi Marc, op , cit , p.7

(4) Picard et André Besson, op, cit , p.291 Beira Ehi Marc, op , cit ,p.19 - المادة | ( / / ع ع تقنين التأمين الفرنسي (o )

(6) Henriette E. Kameni, op , cit ,p.28 
التأمين الأخرى والقيمة المؤمن بها، فهذه المعرفة ستجعل المؤمن له في موقف الرضا عن النفس ، كما أنه يمكن أن يستفيد من ذلك دون أن يدرى وذلك بالحصول على قسط أقل مما

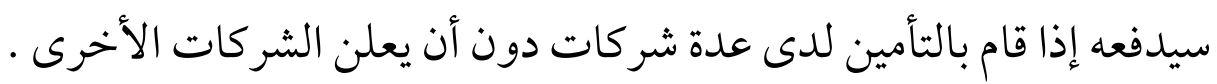
الواقع أن هذه المعلومات التي سيقدمها المؤمن له في هذا السياق لا تهدف إلى تعديل العقد الأول ، وإنما سيكون على الشركة فقط تعويض المطالبة اذا تم تنفيذها وفقا لمبدأ التعويض وذلك كما هو منصوص عليه ؛ وذلك لتجنب قيام العديد من الشركات بدفع تعويض يزيد عن القيمة الحقيقية للشيء.

ومع ذلك فإن خطر تراكم التأمين غير موجود بالنسبة للتأمين على الحياه وتأمين الإصابات والذى يحظى بخصوصية حيث يمكن للمؤمن له أن يقوم بالتأمين على حياته لدى

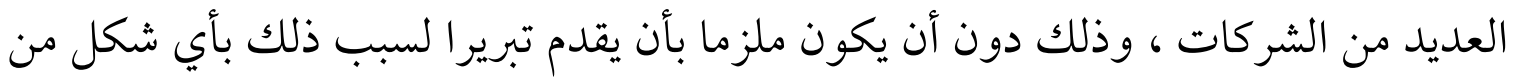
الأشكال ، كما أنه عند حدوث الخطر فسوف تقوم كل شركة من الشركات بسداد الضمان

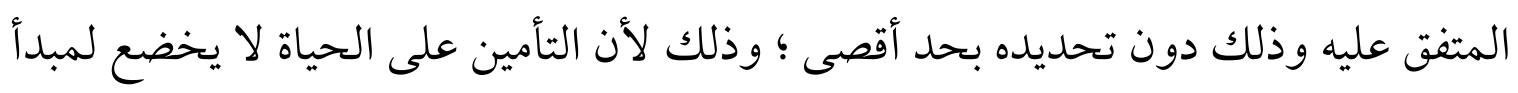

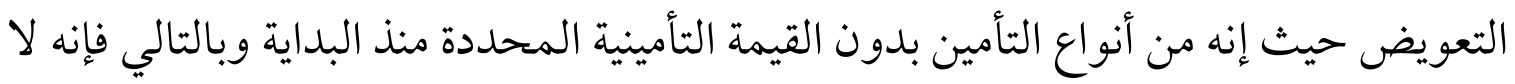

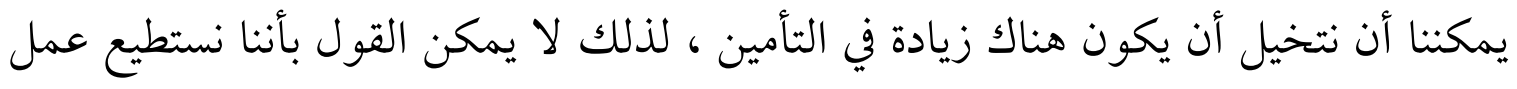
تأمين تر اكمي متعدد في هذه الحالة (1).

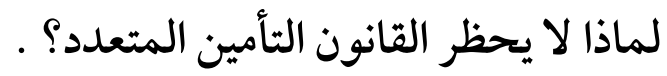
إذا كانت التأمينات المتعددة يمكن أن توفر للمؤمن له الإثراء بلا سبب ، وبالتالي فهي تشكل خطر اعلى النظام العام فلماذا لا يميل القانون إلى حظر هذه التأمينات المتعددة؟؟ب). إن الإجابة على هذا السؤال تذهب إلى القول باستحالة حظر التأمين المتعدد بالكامل ،

(1) Ibid,p.22

(2) Beira Ehi Marc, op , cit ,p.22 
ففي الو اقع إذا كان القانون لا يسمح للشخص أن يحصل على أكثر من قيمة الشيء المؤمن

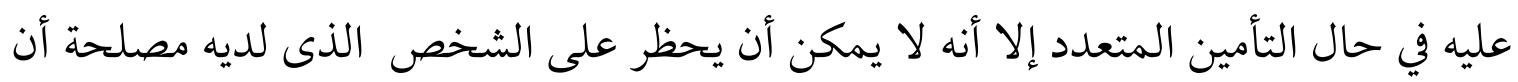

$$
\text { يؤمن على الشيء لدى أكثر من شركه. }
$$

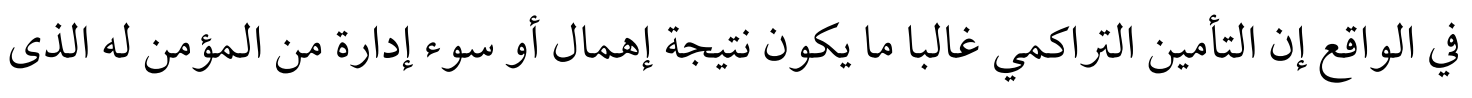

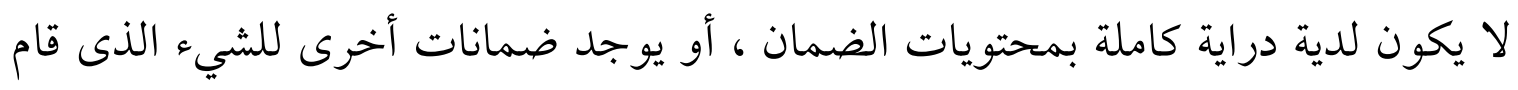
بالتأمين عليه ، وهذا السبب في أنه من النادر جدا في الواقع أن يقوم الشخص المؤمن له له بالإعلان عن التأمين التراكمي الخاص . بالثين

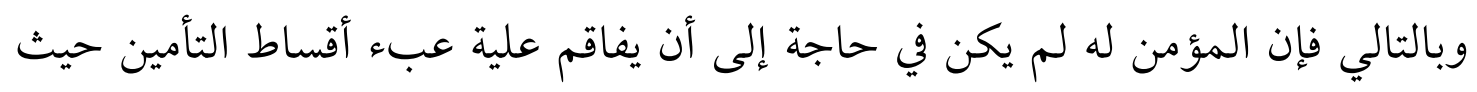

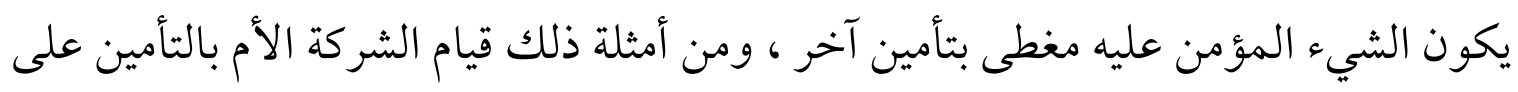

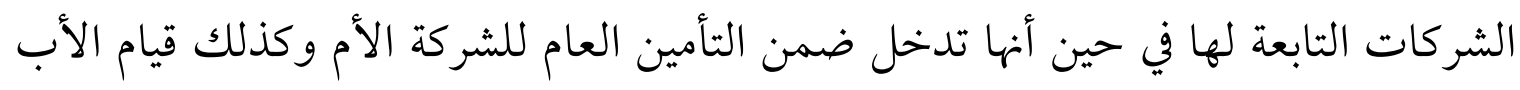
بالتأمين الصحي على ابنه في حين أنه مؤمن عليه من خلال تأمين التلاميذ بالمدارس.

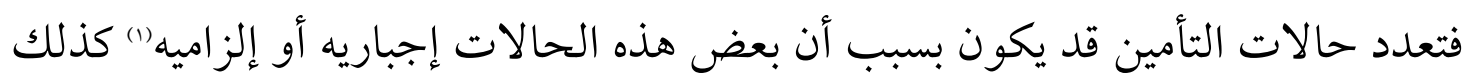

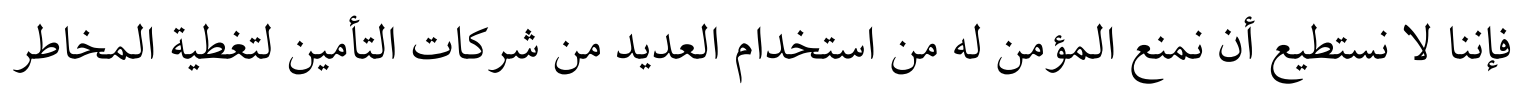
التي تكون أهميتها كبيرة بالنسبة لها بحيث لا يمكن للشركة الأولى أن تقوم بتغطية التأمين كاملا كذلك فإن القيمة المؤمن عليها تخضع دائما للتغيير وخاصة في حالة البضائع ؛ فيكون من الضروري أن يتم تغطية القيمة الزائدة من قبل شركات تأمين غير شركة التأمين الأولى دئى

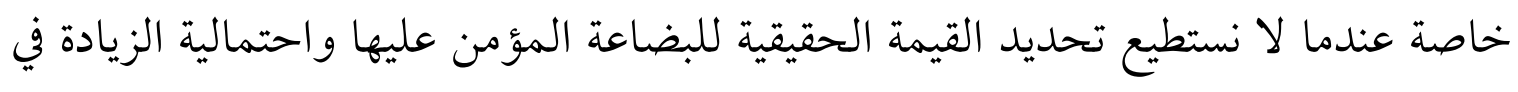
قيمتها منذ البداية("). من خلال الأمثلة السابقة يتضح لنا مدى صعوبة تدخل المشرع لمنع التأمين المتعدد .

(1) Ibid , p.23

(2) Ibid 
رابعا : حسن نية المؤمن له في إعلان الخسارة.

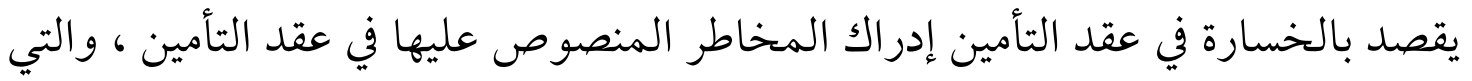

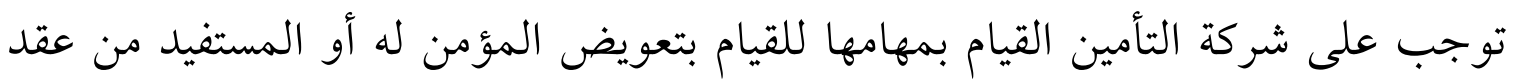
التأمين ، وللقيام بذلك يجب على المؤمن له إبلاغ شركة التأمين بوقوع الخطر المؤمن لهن ضده (1)

فمن مصلحة المؤمن التعرف على وجه السرعة على وقوع الحادث الذى يترتب عليه

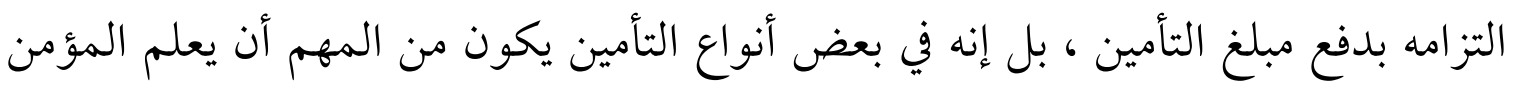

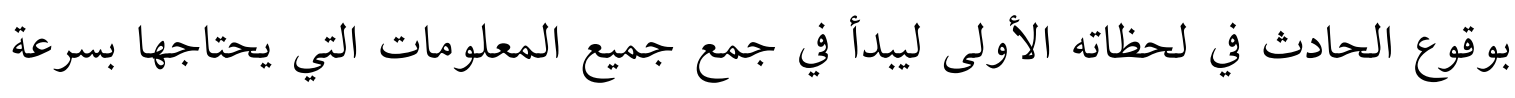

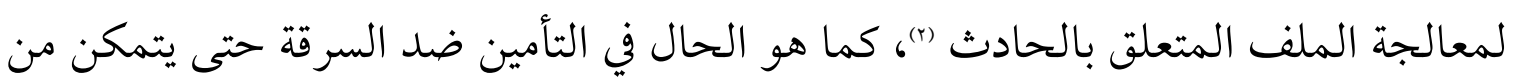

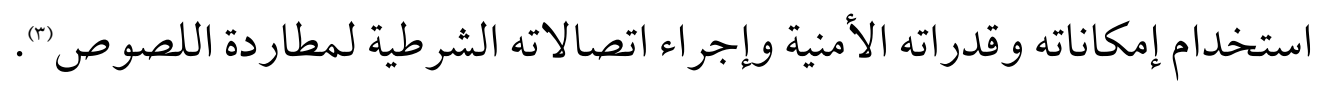

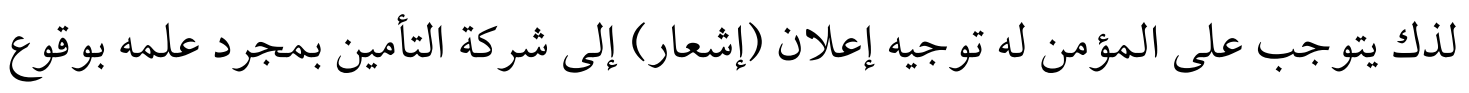

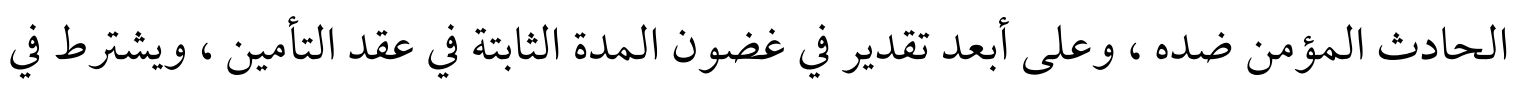
القانون الفرنسي ألا تقل المدة المحددة المتفق عليها عن خمسة أيام ، ويمكن تقليل هذه تهدي

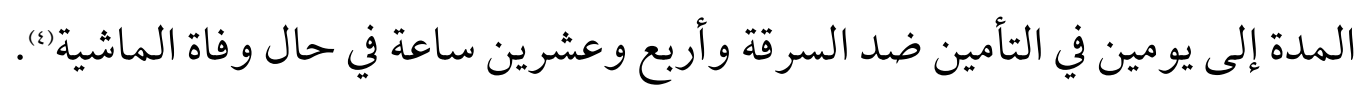
وحيث إن هذا الإعلان يكون في المقام الأول مسئولية المؤمن له إلا أن هذا ليس هو سئ الحسال

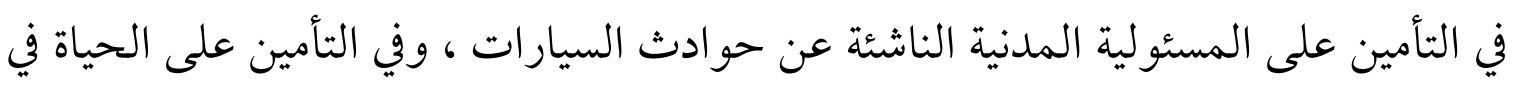
حال الوفاة ، حيث إن المسئولية هنا تقع على عاتق أصحاب الحقوق والشرطة ، بل يمكن

(1) Henriette E. Kameni, op , cit ,p.31

(2) Fulbert Youssouf, op , cit , p. 35

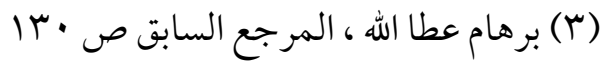

$$
\begin{aligned}
& \text { (ع) المادة r/ / / / من تقنين التأمين الفرنسي }
\end{aligned}
$$


لطرف ثالث القيام بذلك كجزء من إدارة الأعمال .

ولم يشترط المشرع المصري أو الفرنسي أي شكل خاص في الإخطار ، فتحدد كل وثيقة الشكل الواجب أن يتخذه خطاب موصى عليه بعلم الوصول أو خطاب عادى ، أو برقية ،أو تلكس ، أو فاكس ، أو رسالة تلفونية ، أو بالبريد الالكتروني ، أو حتى إخطار شفوي مباشر أو عن طريق التليفون ، أو بأية وسيلة تؤدى إلى علم المؤمن بوقوع المخاطر المؤمن ضدها”'). المشكلة ليست في وسيلة الإخطار أو شكله وإنما في كيفية إثبات المؤمن له بقيامه بإخطار شركة التأمين بوقوع المخاطر الموجبة للتعويض خاصة أن المؤمن له في حاجة إلى إثبات قيامه بالإخطار حتى يتجنب العقوبات التي من المحتمل أن تترتب على عدم الامثثال لهذا الالتزام أو تنفيذه المتأخر (()؛ لذلك درج العمل على استعمال الخطاب الموصى عليه بعلم الوصول كوسيلة للإخطار حيث إنه وسيلة سهلة لإقامة الدليل عليه عند وجود النزاع على وقوعه من عدم وقوعه (() كما درجت شركات التأمين كذلك على إعداد إعلان مطالبة مطبوع مسبقا تتيحه لعملائها كنموذج مصمم لتسهيل جمع المعلومات للتحقيق بشكل خاص في حال المطالبات الصغيرة المتعلقة على وجه الخصوص بالأضرار المادية فقط دون حالات الإصابة الجسدية التي يترك التحقيق فيها للشرطة). ميعاد الإخطار: لم يحدد القانون المصري ميعادا للإخطار بوقوع الحادث المؤمن ضده لذا يمكن الاتفاق على مدة معينة يتم فيها هذا الاخطار ، فإذا لم تم الاتفاق على ميعاد للإخطار فمن الواجب على المؤمن له أو المسئول عن هذا الاخطار أن يقوم به في وقت

$$
\text { (1) (1) محمد حسام لطفي، المرجع السابق ص ب^r }
$$

(2) Fulbert Youssouf, op , cit , p.35

$$
\text { (Y) (Yحمد حسام لطفي ، المرجع السابق ص Nبr) }
$$

(4) Fulbert Youssof, op , cit ,p35 
معقول وإذا تأخر في الإخطار دون مبرر وألحق بتأخره ضررا بالمؤمن كان عليه أن يعوضه

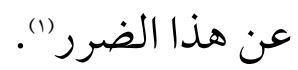

أما القانون الفرنسي فقد ترك أمر تحديد مدة الإخطار بوقوع الحادث المؤمن ضده

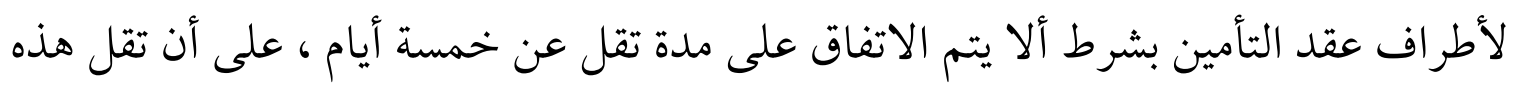

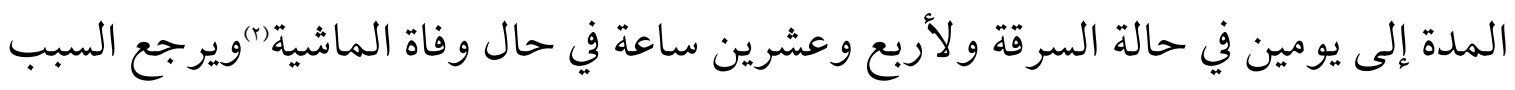

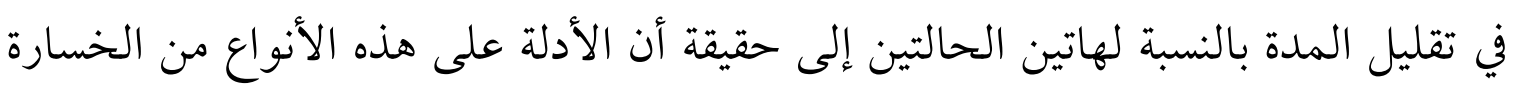

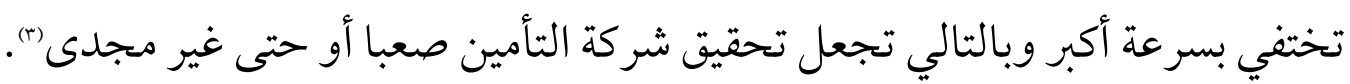

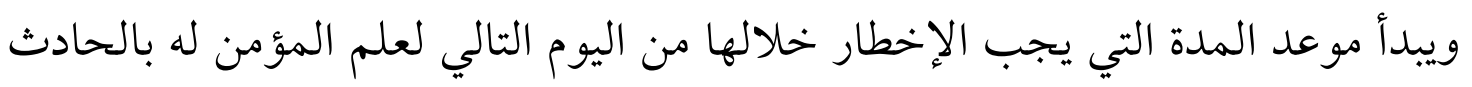
وينتهي في متتصف ليل يوم العمل الأخير وفقا للمدة المتفق عليها ، ولا تنشأ أي صعوبة في الحالة التي يتلازم فيها حدوث الحادث والعلم به في نفس الوقت ، الصعوبات تكون في حال تأخر علم المؤمن له عن وقت حدوث الحادث ، وفي هذه الحالة سوف يتعين عليه تقديم

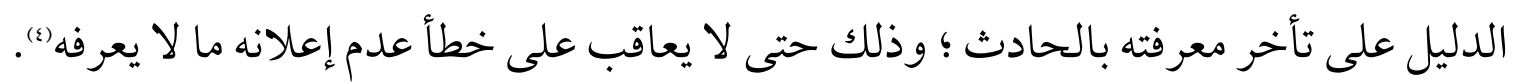
وفي حال عدم قيام المؤمن له بالإخطار بوقوع الحادث المؤمن ضده فإنه يتعرض لعقوبة

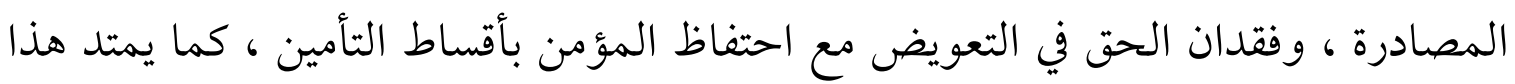
الجزاء إلى حالتي التأخير في الإخطار أو الإخطار غير الدقيق بشرط أن يكون منصوص صا على ذلك بأحرف واضحة للغاية في وثيقة التأمين ، فلابد من إدراج شرط الئسير المصادرة في الوثيقة

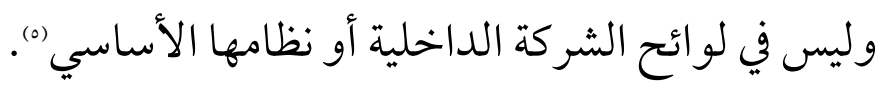

(3) Fulbert Youssouf, op , cit , p.36

(4) Ibid, p.38

(5) Ibid p.40

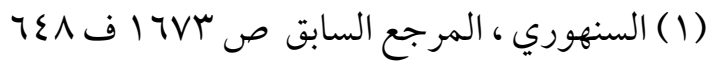

$$
\begin{aligned}
& \text { (Y) المادة r| / / / / من تقنين التأمين الفرنسي. }
\end{aligned}
$$


ويسرى جزاء المصادرة سواء كان المؤمن له حسن النية أو سيء النية ، إلا أنه في حال حسن نية المؤمن له فإن المؤمن بسبب سياسته التجارية ومصالحه تفضيل المؤمن له حسن النية الذى يبدو عقده أكثر جاذبية وفائدة له وذلك بعدم توقيع جزاء المصادرة ضده. ومن أجل تجنب إساءات شركات التأمين فإن هناك حاليين لا يمكن تطبيق المصادرة في حال التأخر في الإعلان ؛ تتمثل الحالة الأولى في عدم حدوث الضرر من جراء التأخير في الإعلان و الحالة الثانية إذا كان التأخير بسبب قوة قاهرةة('وبالتالي فإن غياب الضرر الذى لحق شركة التأمين بسبب التأخير في الإعلان وغياب القوة القاهرة يمثلان عقبة أمام تطبيق المصادرة). (1).

كذلك فإن التأخير البسيط في الإعلان لا يترتب عليه مصادرة المؤمن للتعويض ، ومع ذلك فيحق للمؤمن إذا أثبت حصول الضرر له من جراء التأخر البسيط فيحق له الحصول على تعويض يتناسب مع الضرر الناجم من هذا التأخير (م). ويترتب على المصادرة فقدان الضمان فقط على هذه المطالبة و لا أثر لها على عقد التأمين حيث إن المصادرة ليست سببا لإنهاء العقد ، فيظل العقد ساريا بالنسبة للمطالبات الأخرى كما أنها لا تسرى في تأمين المسئولية في مواجهة الضحية الذى له إجراء مباشر ضد المؤمن وكذلك على حوادث العمل (i)كما أن هذا الحكم يمتد إلى الرهن العقاري والدائنين الممتازين في التأمين على الممتلكات (ن). وقد أثبتت الممارسة العملية صعوبة تطبيق المصادرة لسبين : السبب الأول الصعوبات

$$
\text { (1) المادة r| / / / بمن تقنين التأمين الفرنسي - المادة • r/ / من قانون CIMA }
$$

(2) Fulbert Youssouf, op , cit ,p42

$$
\text { CIMA المادة • • ا ب من قانون }
$$

Fulbert Youssou , op , cit ,p.42 - CIMA ( ) المادة Yo من قانون

(5) Fulbert Youssouf , op , cit , p.44 
التي يو اجهها المؤمن لتقديم دليل على الأضرار الناشئة نتيجة التأخير في الإعلان عن الحادث الموجب للتعويض ، السبب الثاني بسبب المنافسة في سوق التأمين التي تجبر شركات التأمين

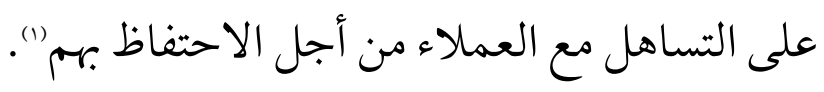

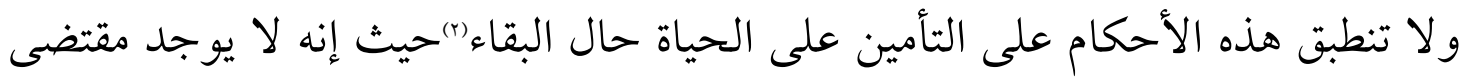

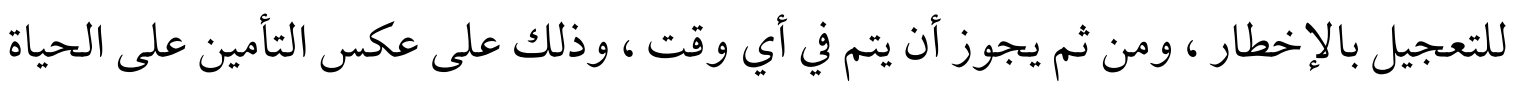

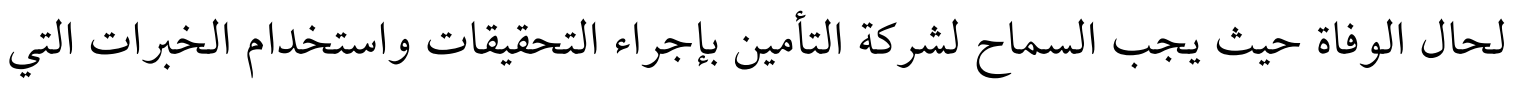
لديها بخاصة في الكشف عن حالات الانتحار المحتملة"). الإخطار وفقا لشروط الضمان : على الرغم من أن المشرع يلزم المؤمن له بالإعلان عن

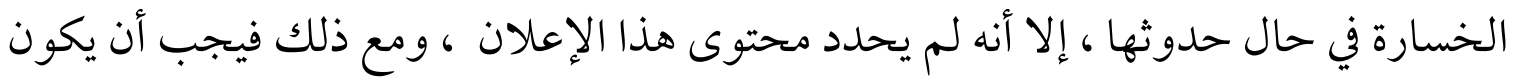

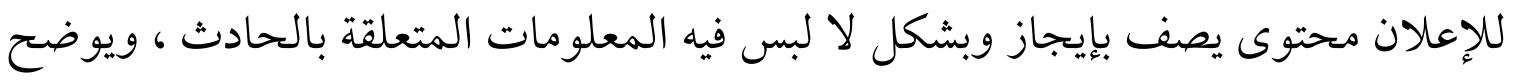
خصائصه الأساسية وهي تاريخ ومكان الحادث ، والتحقيقات التي تمت وأسماء الضحايا

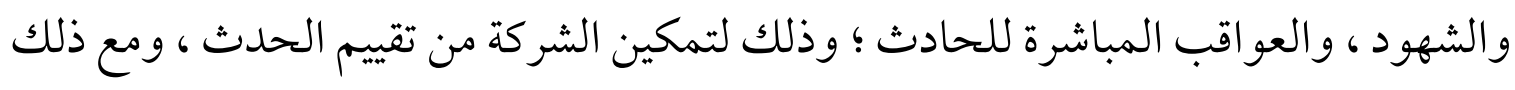

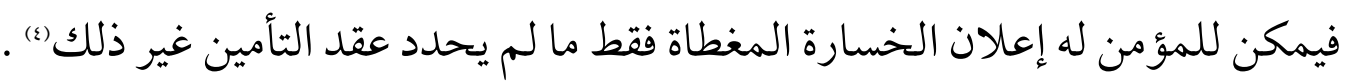

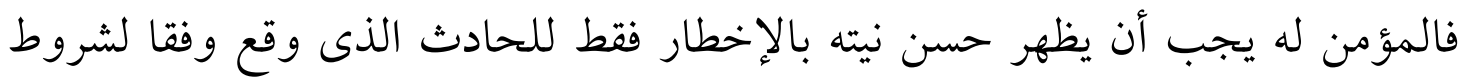

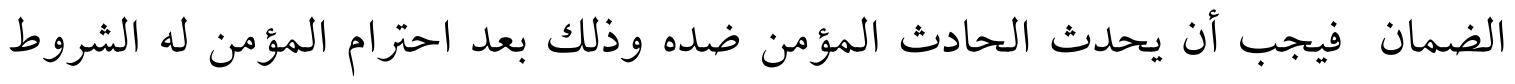
المنصوص عليها بعقد التأمين والمتعلقة بقواعد الحصافة والتدابير الاحترازية ، ففي التأمين ضد السرقة يجب أن تكون السرقة المعلنة قد حدثت بعد تعزيز حماية الأبو اب وإنشاء جهاز

(1) Ibid

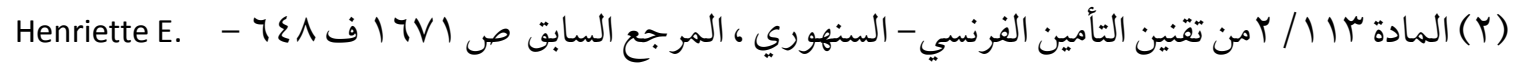
Kameni,op, cit ,p.32

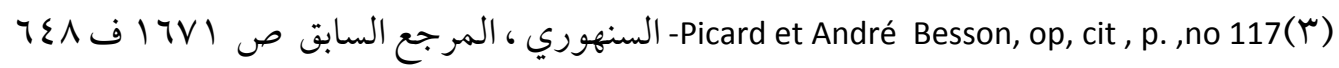
(4) Fulbert Youssouf, op , cit , p.36 
إنذار من قبل المؤمن له وفقا لما اتفق عليه بعقد التأمين (1). ومع ذلك ومن أجل الحصول على تعويض محتمل أو لغرض احتيالي يعلن المؤمن له في كثير من الأحيان المطالبات التي حدثت في ظروف معاكسة والتي غالبا ما تكون بسببه ؛ كما في حالة الحريق المتعمد الناجم عن التجار أو الشركات التي في إطار التصفية والتي تتهرب ضريبيا من أداء الضرائب الواجبة عليه ، وكذلك الحال بالنسبة للمنتجات التي يتم تدميرها سرا ، وفي حالة الإصابات الذاتية للرياضيين أو الفنانين رفيعي المستوى (). فكل هذه الخسائر التي تسبب فيها المؤمن له عمدا أو بسبب عدم امتثاله للقو اعد المتفق عليها المتعلقة بالتدابير الاحترازية ليست قابلة للتأمين ، وإقامة الدليل عليها يقع على عاتق شركة التأمين . الإعلان الحصري عن تحقق المخاطر المؤمنة : يجب أن يكون المؤمن له حسن النية أيضا في توجيه إعلان حصري إلى المؤمن عند إدراكه الخطر المؤمن منه وفقط وذلك بمجرد علمه بوقوع هذا الخطر. فالمؤمن له مطالب بتجنب الإعلان عن المطالبات الناشئة عن إدراك مخاطر بخلاف المخاطر المنصوص عليها في عقد التأمين أو بملحقاته المرفقة به ، كذلك يجب عليه تجنب إعادة ترتيب الوقائع لتكون في حدود الضمان المتفق عليه وذلك ما يسمى بحظر المطالبات المعدلة ، كإدراج أضرار ليس لها صلة بالحادث ، أو تكييف الأحداث مع العقد الذى يستبعدها ،أو باستبدال الأشخاص كما في التأمين الصحي"(r). علاوة على ذلك يجب على المؤمن له أن يظهر حسن نيته بإعلانه تحقق الخطر المؤمن ضده وفقط دون أن يكون هناك مبالغة في الحادث أو تغييره وبالتالي فإن أية مبالغة طوعية في

(2) Ibid

(3) Ibid , p.34 
حجم المطالبات يتم استنكارها .

كذلك فإنه يحظر على المؤمن له الإعلان عن مزاعم وهمية مثل السرقة الكاذبة للسيارات

،أو الأمراض الوهمية ، أو إعلان حالات الوفاة للموتى الذين لا يزالون على قيد الحياة.

فالمؤمن له يجب لأن يكون مخلصا لشريكه في عقد التأمين أن يبعد كل البعد عن هذه

الحيل الاحتيالية عند إعلانه للمؤمن بحدوث الخطر الذى يترتب عليه الضمان

إدارة الكارثة واتخاذ تدابير الإنقاذ.

يجب على المؤمن له إضافة إلى إعلانه المؤمن بحدوث الخسارة المؤمنة أن يظهر حسن

نيته من خلال تصرفه بمسئولية وحكمة مستنيرة تجاه إدارته للحادث المؤمن ضده في حال

وقوعه.

ويقصد من ذلك تصرف المؤمن له تجاه المؤمن مثلما يتصرف أفراد العائلة ، فيتصرف

التصرف الذى يحمى شريكه بعقد التأمين باعتبارهما عائلة واحدة'() وباعتبار هذا التصرف هو

مكافأة من أحد أطر اف العائلة للطرف الأخر ().

فيجب على المؤمن له عند وقوع الكارثة أن يكون مجتهدا في إدارة هذه الكارثة باتخاذه جميع التدبير الاحترازية من أجل الحد من تفاقم الكارثة(()وبالتالي محافظته على مصالح شر كة التأمين.

في كثير من الأحيان تكون هذه الالتزامات تعاقدية يتم النص عليها صراحة في عقد التأمين

(1) فالمتعاقدين وفقا للفقيه Demogue يشكلون مجتمعا صغيرا يلتزم فيه كل فرد بالعمل لتحقيق هدف مشترك والمتمثل في جملة الأهداف الفردية التي يرمى إليها كل فرد ، تماما مثلما هو الحال في الشركة المدنية

(2) Henriette E. Kameni, op , cit , p.35

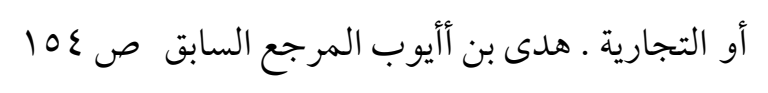

السنهوري ، المرجع السابق ص $17 V 0$ 
فيتم فرض هذه السلوكيات على المؤمن له أثناء أو بعد الحادث بخاصة في بعض أنواع

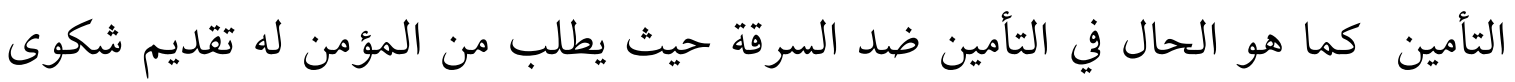
للشرطة والحصول منها على الإيصال الدال على ذلك والذى يجب أن يكون مقرونا

$$
\text { بالإعلان بحدوث الكارثة) (1). }
$$

في التأمين ضد الحريق يجب على المؤمن له اتخاذ جميع التدابير لإنقاذ الممتلكات التي لم يتم تدميرها بالكامل عن طريق عزلها ونقلها بعيدا عن الحريق كذلك العمل على الحد من امتداد الحريق عن طريق الاتصال بإدارة مكافحة الحرائق على وجه السرعة ، في حال تأمين انقطاع العمل يجب على المؤمن له أن يتخذ التدابير اللازمة لتقليل مخاطر الوقف الكلى

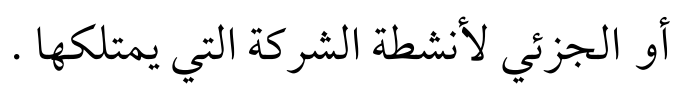

هذه الأعمال والسلوكيات الصادرة من المؤمن له سيكون لها أثر كبير في تقييد نطاق الكارثة وفي تعويض الحادث : فمن خلال اتخاذ المؤمن له خطوات الحد من الخسارة وتقليلها يكون قد أظهر حسن نيته ـ فحقيقة التصرف بإخلاص وياعتبار طرفي عقد التأمين عائلة واحدة يكون له تداعيات كثيرة على التعويض فإذا كانت العناية المطلوبة مؤكد عليها

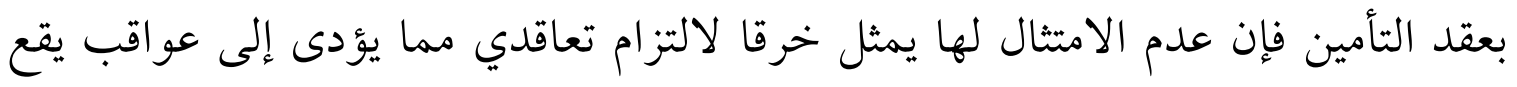
كاهلها على المؤمن له الذى لم يؤد السلوك المطلوب("). المشكلة فقط تكون بتعلق الأمر بسلوكيات وتدابير الإنقاذ ويكون هذه السلوكيات غير منصوص عليها بعقد التأمين فمن سيتحمل المسئولية الناجمة عن تفاقم الكارثة ؟

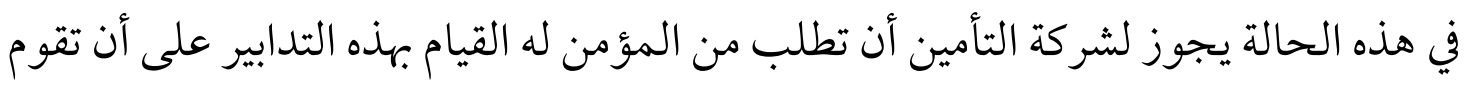
بتحمل كل المبالغ التي يتحملها المؤمن له لاتخاذ هذه التدابير.

(1) Picard et André Besson, op, cit, no 1115

(2) Lamy assurances, 2005, op. cit. p.319-320 
أما في حال صمت العقد و كذلك عدم طلب شركة التأمين من لمؤمن له للقيام باتخاذ هذه

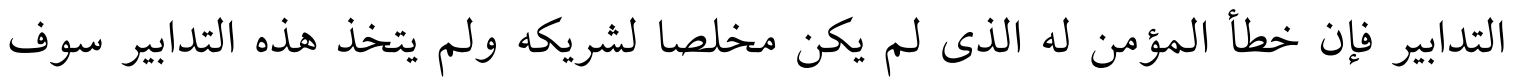
يخضع التقدير للقضاء ، والذى في كثير من الأحيان يحمل المؤمن له مسئولية تفاقم الخسارة و التي تكون في الغالب مقترنة بالتأخر في الإعلان عن الخسارة ـ أما إذا لم يثبت خطأ المؤمن

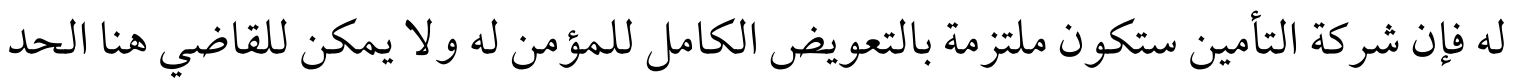

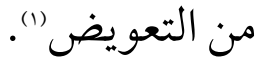
خامسا : حسن نية المؤمن له في التعاون والالتزام بتنفيذ شروط الضمان

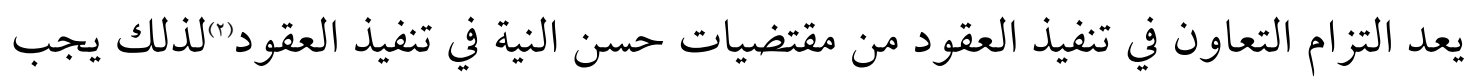
على المؤمن له أن يكون عادلا مخلصا لشريكه في عقد التأمين بالتعاون معه ، وبخاصة عند تحقق الخطر الناشئ عن خطأ الغير.

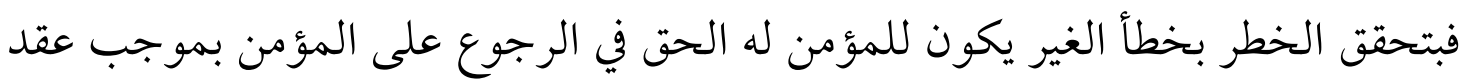

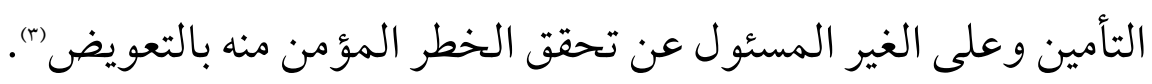

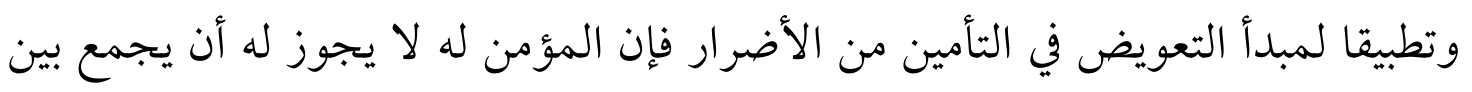

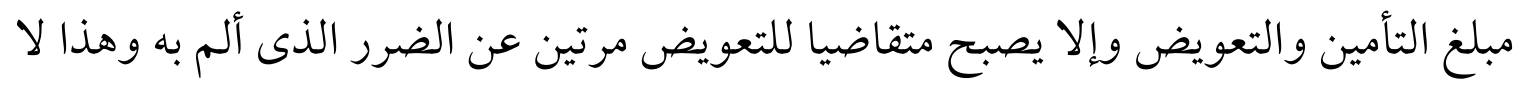

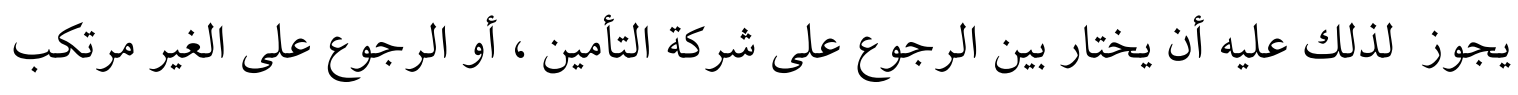

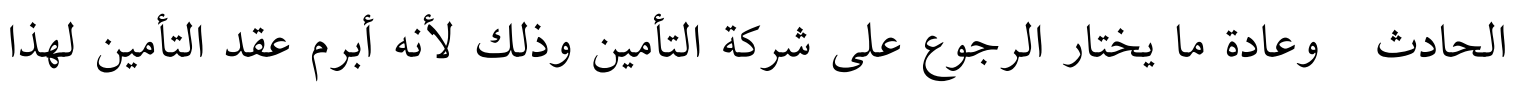

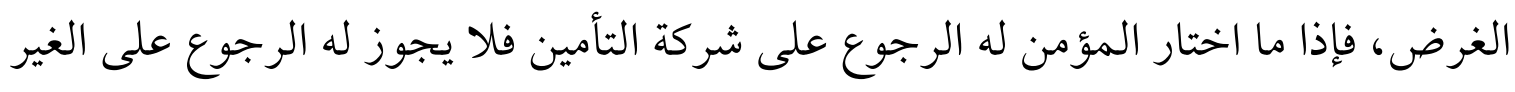

(1) Ibid -

$$
\begin{aligned}
& \text { (Y) هدى بن أيوب ، المرجع السابق ص ع } 10
\end{aligned}
$$

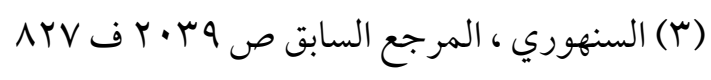


المسئول وبالتالي يكون لشركة التأمين الحلول محل المؤمن له في هذا الرجوع (1). فيجب على المؤمن له التعاون بحسن نية مع المؤمن لاسترداد التعويضات التي سيدفعها له المؤمن وذلك بحلول المؤمن في حقوق المؤمن له تجاه الغير المسئول عن الحادث). وهذا الحلول يفرض على المؤمن له عدة التزامات من أجل الحفاظ على حقوق المؤمن ومنها وجوب عدم تنازل المؤمن له عن حقه ، فإذا قام المؤمن له بالإقرار للغير المسئول بعدم مسئوليته أو بإبراء ذمته ، فإنه يضيع بذلك دعوى الحلول على المؤمن وسيكون نتيجة ذلك رجوع المؤمن على المؤمن له بالمقدار الذى ضاع عليه بفعل المؤمن لهام. فيجب على المؤمن له أن يقوم باتخاذ كل الإجراءات التي تحمى المؤمن تجاه الغير (s)في المواعيد القانونية المقررة ، فلا يترك المؤمن له دعواه تجاه الغير المسئول تسقط بالتقادم حتى يرجع بعد ذلك على المؤمن(م) ؛ وذلك لأنه في هذه الأحوال سيمتنع المؤمن عن دفع التعويض ، كما أنه سيسترد ما دفعه. كما يجب على المؤمن له إثباتا لحسن نيته وتعاونه مع المؤمن أن يعلن له جميع الظروف المتعلقة بالخسارة التي يعلمها دون إخفاء أي معلومات مطلوبة حماية للغير المسئول الذى لا يريد متابعته ، كما أن المؤمن له ملتزم بالإدلاء بشهادته في الدعوى المرفوعة ضد الغير المسئول خاصة عندما يستند الدليل في الدعوى أساسا على هذه الشهادة (1).

Christianne Dubreuil,op , cit ,p.1102 (1) - مدنى مصري - ولا يتم تطبيق الحلول في التأمين على VVI الم الحياة

(2) Khalifi Taghzouti et d'autres, op , cit, p.5

(4)Christianne Dubreuil , op , cit ,p.1102

$$
\text { (r) السنهوري ، المرجع السابق ص 0؟ • ب ف ابی }
$$

$$
\text { (0) السنهوري ، المرجع السابق ص 0؟ • ب ف ابی }
$$

(6) Christianne Dubreuil , op , cit ,p.1102 
كذلك الحال بخصوص التأمين من المسئولية والتي يكون الخطر المؤمن منه ليس هو تحقق مسئولية المؤمن له ، وإنما هو مطالبة المضرور للمؤمن له بالتعويض ، وقد تكون مطالبة المضرور للغير مطالبة ودية وقد تكون قضائية ، في كلتا الحالتين فإن المؤمن له ملتزم بإخطار المؤمن بكتاب موصى عليه بعلم الوصول بوقوع المطالبة").

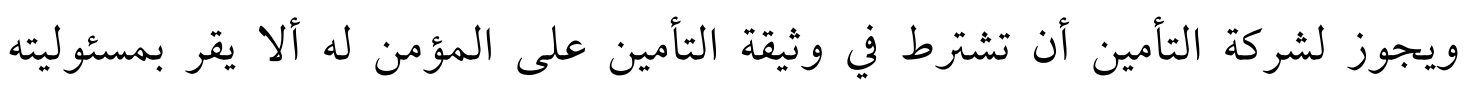

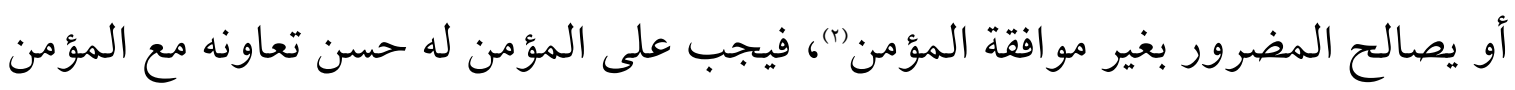

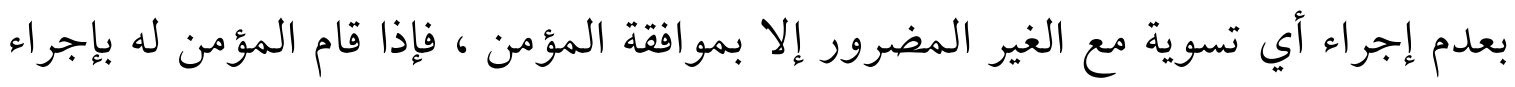
التسوية الودية مع المضرور رغم الحظر المفروض عليه فإن عقوبته هي عدم إمكانية تنفيذ

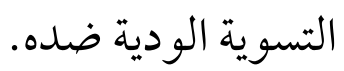

فالمؤمن له ملتزم بالو لاء لشريكه بعقد التأمين حتى يتم التنفيذ الكامل لعقد التأمين وحتى

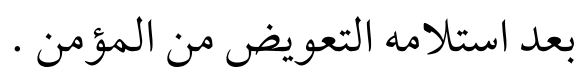

(1) المادة بـ من مشروع وزارة الاقتصاد - يقابلها المادة 11 1 من من المشروع التمهيدى للقانون المدني.

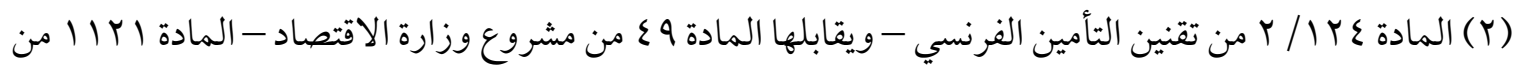

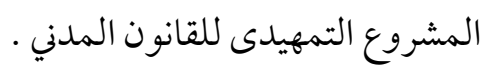




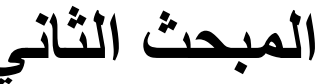 \\ حسن نية المؤمن ( شركة التأمين)}

إن الالتزام بمبدأ حسن النية في عقد التأمين لا يقع على عاتق المؤمن له وحده ، إنما يستهدف أيضا جعل المؤمن يتعاقد مع الطرف الأخر وفقا لهذا المبدأ(1) بحيث يمتنع عليه

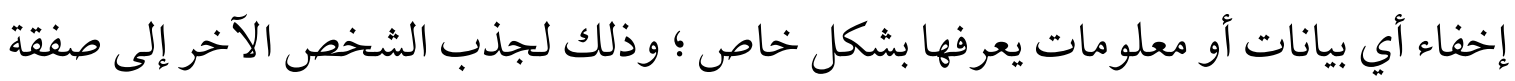
أو تعاقد يترتب على جهله بهذه المعلومات مع اعتقاده بأنه يعرف كل الحقيقة"(ه).

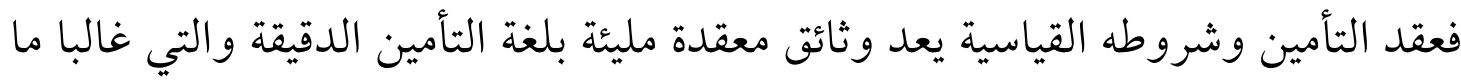
يكون فهمها صعبا(")ومشوشا بالنسبة لحملة الوثائق ؛ وذلك لأن معرفتهم ليست متخصصة وبالتالي يتم فهمها بالخطأ من جانبهم مما يؤدى إلى التمثيل الزائف لنيتهم الحقيقية في

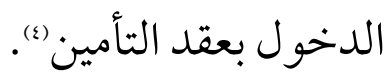
وإذا كان عقد التأمين عقدا ملزما للجانبين فإن المؤمن يقع عليه مثلما هو حال المؤمن له أن يكون متحليًا بأقصى قدر من حسن النية بداية من مرحلة المفاوضات التي تسبق إبرام

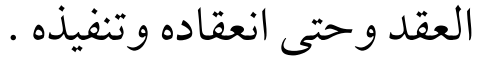

وسوف نقوم بدراسة حسن نية المؤمن في المطالب التالية : المطلب الأول : حسن نية المؤمن في مرحلة المفاوضات المطلب الثاني : حسن نية المؤمن عند إبرام العقد : لئل

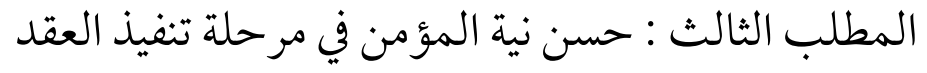

(1) محمد الهيني ، الحماية القانونية للطرف الضعيف في عقد التأمين البرى ، دراسة مقارنة ، الناشر مكتبة دار

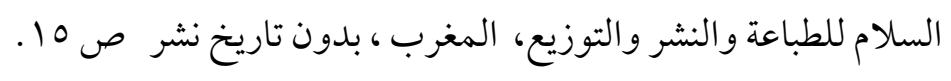

(2) Yiqing Yang, op , cit ,p.157.

(r) وليد سليمى ، أحمد الصيد ، ضمانات التوازن لتنفيذ عقد التأمين - مجلة الحقوق و العلوم الانسانية

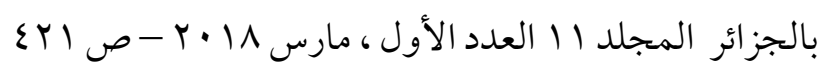

(4) Yiqing Yang , op , cit ,p334-335. 


\section{المطلب الأول

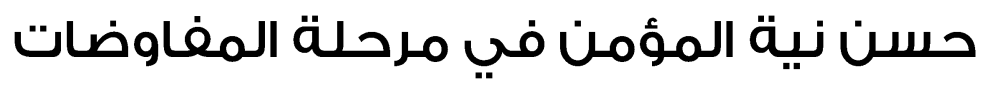

تتخذ الشفافية في القانون شكل المعلومات الصادقة الدقيقة ، وهي تلعب دورا متزايدا في

التزامات المهنيين في جميع قطاعات الحياة المهنية") و التي منها التأمين حيث تعتمد على مبدأ هام هو أن المهني مطالب بإبلاغ المستهلك بمعلومات واضحة ومفهومة وفي حال الغموض سيتم تفسير الاتفاق لصالح المستهلك .

وحيث إن المهني في عقد التأمين هو المؤمن ( شركة التأمين ) ؛ لذلك فمطلوب منه إعلان

المؤمن له بالمعلومات المتعلقة بعقد التأمين وذلك بدقة ، وصدق ، وحسن نية كما هو حال المؤمن له ؛ حيث إن واجب المعلومات في عقد التأمين له خصو صية كبيرة حيث لا يقتصر الالتزام بتوفير المعلومات للمهني فقط ، وإنما هذا الأخير ملتزم بالتزام من نفس النوع . ا-التزام المعلومات: تعتبر الموافقة الحرة المستنيرة من طرفي عقد التأمين شرطا أساسيا لصحة العقد ، ولتحقيق هذا الهدف فإن القانون يفرض على المؤمن له مقدم طلب التأمين الالتزام بالإعلان عن الوقائع ذات الصلة بالمخاطر ، كما يفرض على المؤمن باعتباره الطرف الثاني بالعقد أن يقدم للمؤمن له المعلومات الكافية عن إمكانيات التغطية التي يقدمها عقد

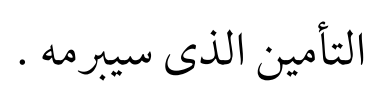

في الماضي كان الالتزام بتقديم المعلومات في المرحلة السابقة على التعاقد يقع فقط على المؤمن له ، ولم تتضمن أغلب التشريعات أي نصوص عن التزام المؤمن بالمعلومات أو بتقديم المشورة للمؤمن له قبل أو حتى خلال إبرام عقد التأمين (r). فقد كان الالنزام فقط

(1) M. B. CRESCENZO-D'AURIAC, op , cit ,p.1 (Y) عمرو جويده - حماية مستهلكي التأمين - رسالة دكتوراه ، جامعة الجزائر ا، كلية الحقوق ، العام الجامعي , الجي $v 1 \rho r \cdot 1 \varepsilon / r \cdot 1 r$ 
على المؤمن له أن يعلن بالضبط في وقت إبرام العقد كل الظروف المعروفة لشركة التأمين حتى تستطيع تقييم المخاطر التي ستتحملها. وكان نتيجة ذلك أن المؤمن له بعد إبرامه عقد التأمين وخاصة عند وقوع الكارثة يواجه و اقعا مختلفا للغاية عما كان يتصوره ، وفي ظل وجود هذا العيب بخاصة في بيئة تتسم بالنمو الفعال لحماية المستهلك ، ومراعاة للانتهاكات التي تعرض لها عملاء التأمين بسبب طبيعة هذا العقد"()؛ كونه عقدا من عقود الإذعان التي يضع فيها الطرف القوى المحترف شروط العقد كيف يشاء بلغة تصعب على عميل التأمين ، فلقد أصبح العصر الحديث يكاد لا يعرف الطرف الضعيف أو المذعن من الناحية الاقتصادية بقدر ما يعرف الطرف الضعيف من ناحية العلم والدراية ، وأصبح عدم التكافؤ بين طرفي العقد ليس اقتصاديا بقدر ما هو عدم تكافؤ في المعلومات المتصلة بالعقد(()؛ مما دعا إلى تدخل المشرعين في هذا الأمر وذلك لحماية المؤمن لهم عملاء التأمين بفرض التزام على المؤمن بأن يقدم المعلومات المسبقة للمؤمن له وذلك قبل إبرام عقد التأمين (r)بحيث أصبح المؤمن يلعب دور المستشار المهني والاجتماعي لعملاء التأمين (s) ويعتبر التزام المعلومات المسبقة من قبل المؤمن من قبيل التعاون التعاقدي ثنائي الجانب(ه)الذى يعد دليلا على تبادلية عقد التأمين وتعبيرا عن أقصى درجات حسن النية()

(1)PATRICE FIL , op , cit , p.2

مريم طويل ، قانون السوق وفكرة توازن مصالح المنتج وحقوق المستهلك ، دراسة مقارنة ، كلية الحقوق

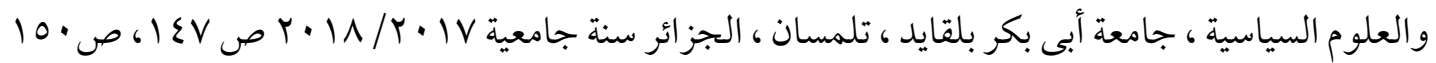

(4) Henriette E. Kameni, op , cit ,p.41

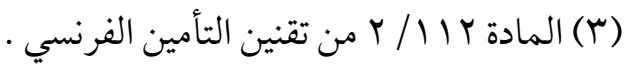
(0) الالتزام بالتعاون ليس له اتجاه وحيد فإذا كان المدين مطالب بتنوير أكبر قدر ممكن من الفاعلية ، فالدائن مطالب من جانبه بتسهيل مهمة المدين وذلك بعيدا عن اخلال هذا الاخير بالتزامه ، فالتعاون التعاقدي ثنائي

(6) Yiqing Yang, op , cit , p.134

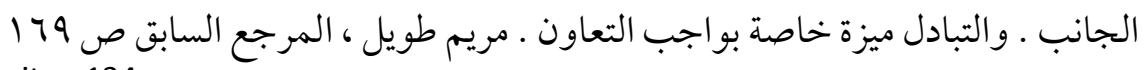


حيث إن المؤمن له يحتاج إلى أن يكون على علم بالإمكانيات التي يمكن تقديمها له من

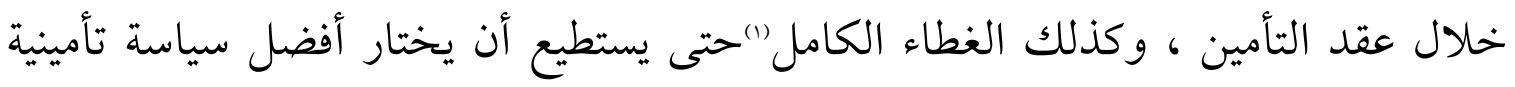
تناسبه خاصة أن حرمانه من المعلومات السابقة على التعاقد تعمل على اختلال التوازن العقدي- الذى يعد توازنا معرفيا(ه)- لذلك فإن الحاجة إلى المعلومات الحقيقية التي تقدمها شركة التأمين مطلوبة لاستعادة هذا التوازن").

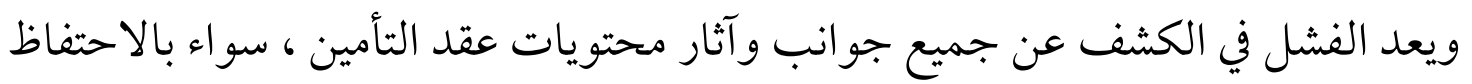
الطوعي للمعلومات ، أو الكذب عن طريق السهو، سلوكا يتعارض مع الضرورات الأخلاقية

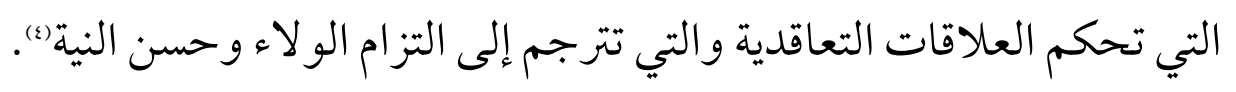

نتيجة لذلك ففي مرحلة المفاوضات يجب أن يكون المؤمن حسن النية تجاه المؤمن له له أثناء تقديمه لاسمه التجاري وقدر اته وإمكاناته في مجال التغطية).

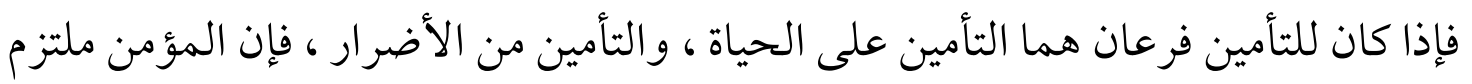

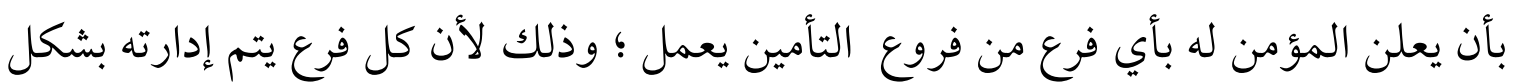
مستقل (1) وإذا كان للشركة أكثر من فرع وأكثر من خط تأمين فيجب أن يعلمه بذلك حتى لـ لا تحدث بلبلة أو خطأ من جانب المؤمن له .

فيجب على المؤمن أن يقوم بتقديم عرض عادل للمؤمن له بمو افقته على تحمل المخاطر التي تندرج في مجال اختصاصه وبما يتوافق مع قدراته على التغطية)وفي سإذا كانت المخاطر

(1) Khalifi Taghzouti, et d'autres, op , cit, p.7

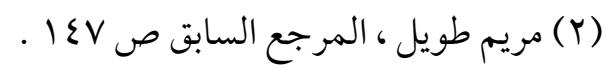

(3) Henriette E. Kameni, op , cit , p.42

(4) Camila HABOUBI, op , cit, no 566

(5) Christianne Dubreuil, op , cit , p.1099

(6) Henriette E. Kameni, op , cit ,p.48

المادة 1) مكرر من اللائحة التنفيذية لقانون الإشر اف والرقابة على التأمين المصري. 
تتجاوز قدرة المؤمن على التغطية فيمكن تأمينها بالاشتراك مع شركة تأمين أخرى من خلال

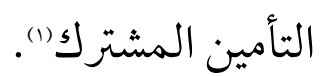

وإذا كان المؤمن له يتعامل مع الوكيل العام المفوض من شركة التأمين فيجب على هذا الوكيل أن يتحدث مع العميل المحتمل بصفته وكيل عن الشركة ويذكر ذلك بوضوح أثناء

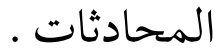

كما يجب على شركة التأمين إظهار حسن نيتها من خلال تقديم إعلان عادل وصادق لهيكلها(()فيمتنع عليها الإعلان الزائف عن اشتراكات العقود التي لا وجود لها ، إضافة إلى تلى حظر الدعاية الكاذبة(r)و حظر التواطؤ مع أشخاص من خارج مهنة التأمين(). كذلك فإن شركة التأمين ملتزمة قبل إبرام عقد لتأمين بتقديم معلومات حقيقية عن السعر

$$
\text { و الضمانات والاستثناءات (م). }
$$

فيما يتعلق بالنصيحة التي يجب أن تقدمها شركة التأمين فيما يتعلق بالمخاطر المراد تغطيتها فالشركة بصفتها مستشارا مهنيا محترفا في مجال التأمين فإنها ملتزمة بتقديم ورقة حقائق عن سعر التأمين و الضمانات والاستثناءات ، وهذا الالتزام يعد من النظام العام لأنه لا يو جد بند تعاقدي يمكن أن ينتقص منه (1).

(1)Henriette E. Kameni, op , cit , p.47

$$
\begin{aligned}
& \text { (Y) المادة ^^ع مكرر من اللائحة التنفيذية لقانون الإشراف والرقابة على التأمين المصري }
\end{aligned}
$$

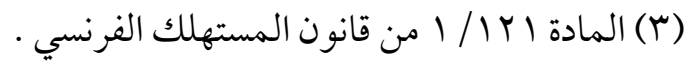

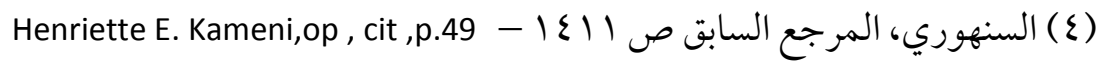

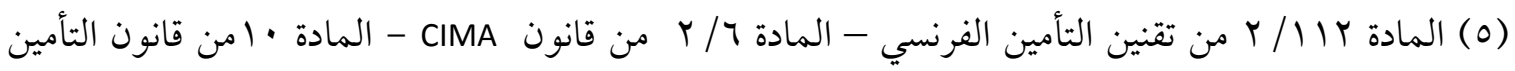

$$
\text { المغربي - Yiqing Yang , op , cit ,p334-335 }
$$

(6) Khalifi Taghzouti, et d'autres, op , cit, p.9 
فيجب على شركة التأمين أن تتيح للجمهور الوثائق التي تحتوى على كافة المعلومات حول الضمانات التي تقدمها في العقود المختلفة ، ويجب أن تكون هذه المعلومات دقيقة في

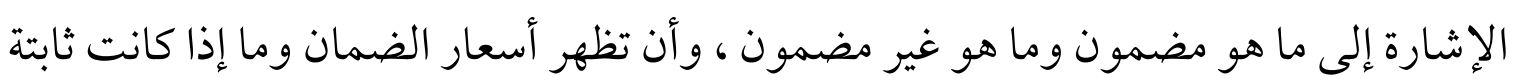
أو متغيرة وطريق وشكل أدائها").

وهذه المعلومات يعتمد عليها طالب التأمين باعتبار أن شركة التأمين في أغلب الأحيان

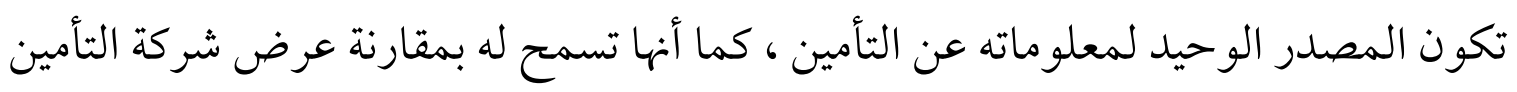

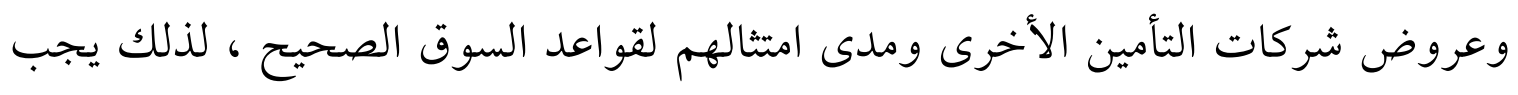

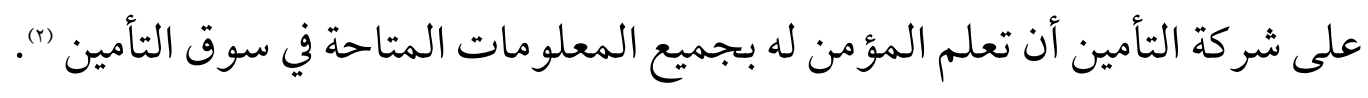

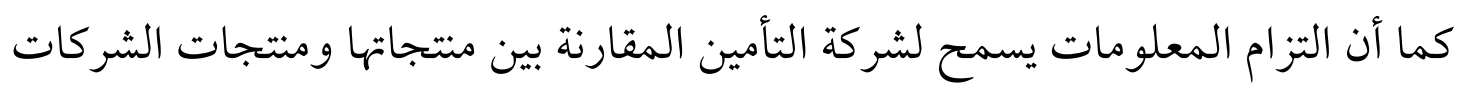
الأخرى ، ومن خلال هذه المقارنة سيتم تسليط الضوء على المزايا التي تقدمها شركة التأمين

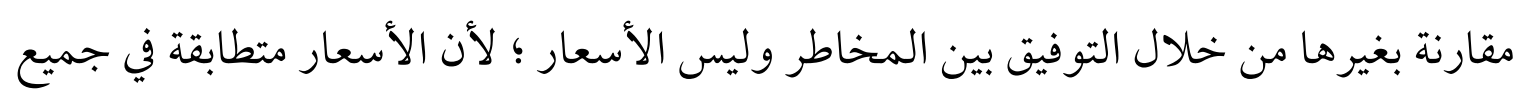
شركات التأمين "(r)

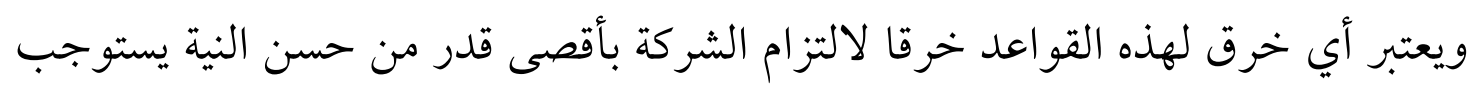

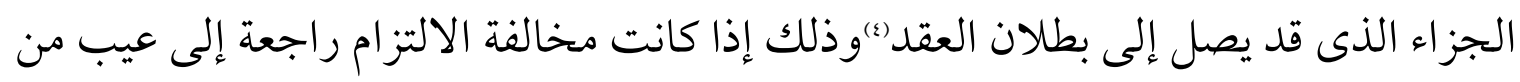
عيوب الرضا، ويمكن أن يكون الجزاء المسئولية المدنية قبل التعاقدية للمؤمن إذا تمكن

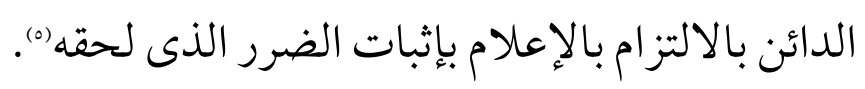

(2) Christianne Dubreuil, , , op , cit ,p.1099

(3) Khalifi Taghzouti, et d'autres, op , cit, p.9

(4) Yiqing Yang , op , cit ,p.237-Henriette E. Kameni,op , cit ,p.43 (0) ولا يعتبر بيان المعلومات إيجابا بل إنه مر حلة ما قبل تعاقدية من أجل إعلام المؤمن له حول شروط العقد قبل

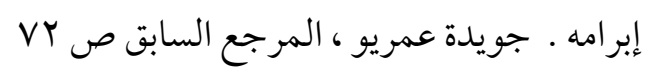


وتعد هذه القو اعد وصفا مفصلا لكيفية تقديم شركة التأمن نفسها بو صفها مستشارا مهنيا كما تعد قو اعد سلوك عامة يجب أن يعتمدها عقد التأمين بداية من مقابلة طالب التأمين إلى

$$
\text { دفع الاشتر اكات"). }
$$

r - الالتزام بالنصيحة والمشورة : بالإضافة إلى دور شركة التأمين باعتبارها مستشار ا مهنيا

لطالب التأمين ، فإن لها دور آخر تقوم به باعتبار ها مستشارا اجتماعيا له وهو تقديم المشورة و النصح (()والتي تتطلب مهارات فنية ، وذلك على عكس الالتزام بالمعلومات التي تعتبر مجرد عرض للبيانات حول المنتج أو الخدمة المعينة"(r). وهذا الدور تجسيدا لالتزام التعاون بين المتعاقدين والذى يعنى قيام كل متعاقد ببذل العناية اللازمة للوصول إلى أفضل صورة وأحسن حال(i) على أن يقع على عاتق المحترف التزاما بالتعاون احتراما للثقة الخاصة التي يضعها فيه المتعاقد معه باعتباره مقتنعا بما له من إمكانيات اقتصادية ومهارة فنية (0). وهذا الالتزام كان ثمرة الاجتهاد القضائي منذ حكم محكمة النقض الفرنسية الصادر في •ا نوفمبر ع797 نتيجة عدم المساواة والكفاءة بين المؤمن المحترف والمؤمن له المستهلك ولم يكن له أي أساس في النصوص القانونية()(إلى أن قرره المشرع الفرنسي على وسطاء التأمين. فأصبح هذا الالتزام مطلوب من وسطاء التأمين والوكلاء العامين وكذلك المصرفيين الذين يوزعون عقود التأمين وشركات التأمين وشركات إعادة لتأمين (vوبشكل

(1) Henriette E. Kameni,op , cit ,p.43

(2) PATRICE FIL , op , cit , p.28

(3) Khalifi Taghzouti, et d'autres, op , cit, p.7

$$
\text { ( ) هدى بن أيوب ، المرجع السابق ص } 100 \text { هدى بن أيوب ، المرجع السابق ص 10V }
$$

(6) - Cour de cassation, chambre civile 1, du 10 novembre 1964, 62-13.411

(7) Camila HABOUBI, op ,cit,no 575 
عام مطلوب من جميع المتخصصين في التأمين (1)برف النظر عن صفاتهم وروابطهم مع

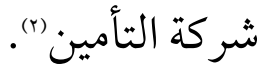

فيجب على شركة التأمين أن تقدم المشورة والنصح لطالب التأمين (م) هذا الو اجب مستمد من الممارسة العملية ولا يقتصر على وقت ما قبل التعاقد بل يمتد طو ال سريان العقد وخاصة أثناء تعديله أو تجديده(8). فيجب على شركة التأمين أن تبين للعميل المحتمل ما يتعلق بفوائد ومخاطر عملية التأمين المقدم عليهاءوأن تكون قادرة على توجيه المؤمن له بما يخدم

(1) واجب تقديم المشورة أصبح مستمد من القانون حيث أوجبته المادة • P / 1 من تقنين التأمين الفرنسي على

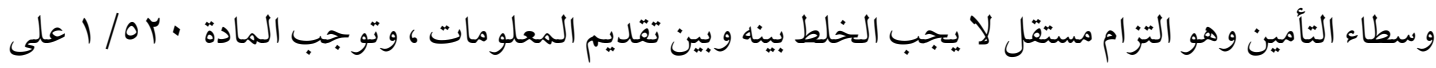
الوسيط أن يجمع كتابيا وفق الطريقة التي يرغب بها الضروريات الاساسية والاحتياجات التأمينية للعميل ، كما يجب على الوسيط أن يعطى للعميل النصيحة المكتوبة ، التي تعتبر وسيلة فعالة لإقامة علاقة ثقة مبنية

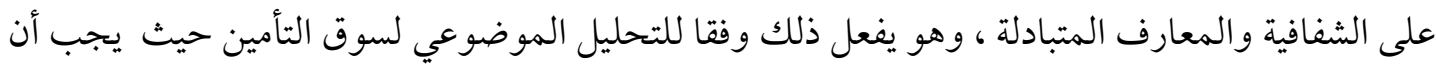
يقوم بتحليل عدد كاف من عقود التأمين المعروضة في سوق العمل من أجل أن يكون قادرا على نصيحة

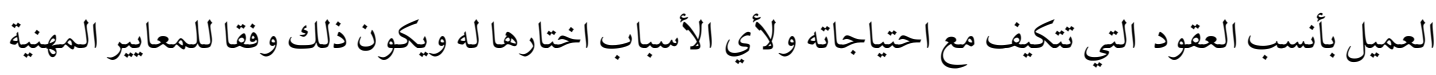
وفي حال عدم تقديم الوسيط المشورة للمؤمن له فسوف يتحمل الوسيط والمؤمن المسيعولية بتفعيل

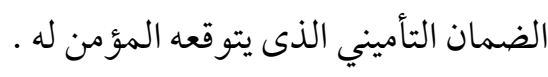

(2) Khalifi Taghzouti, et d'autres, op , cit, p.7 -Christianne Dubreuil,op cit ,p.1099

(r) يعد ذلك من صور الالتزام بالتعاون الذى عرفه البعض بأنه كل سلوك وتصرف والتزام التوام يتعلق بكيفية تنفيذ العقود يحمل على كاهل المتعاقدين سواء كان مدينا أو دائنا ولم يقع الاتفاق عليه بين المتعاقدين اتفاقا

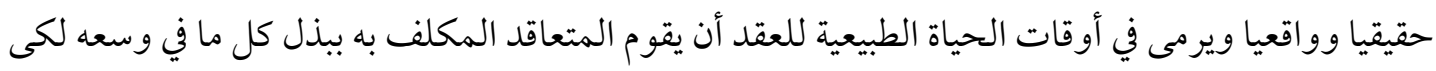

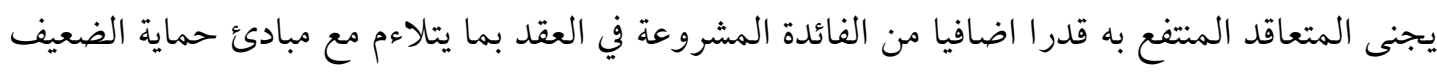
وحسن تنفيذ العقود ومبادئ التحضر في القانون الحديث .

سفيان الفرجي ، واجب حسن النية في تنفيذ العقود في القانون التونسي والقانون المقارن رسالة دكتوراه ، كلية

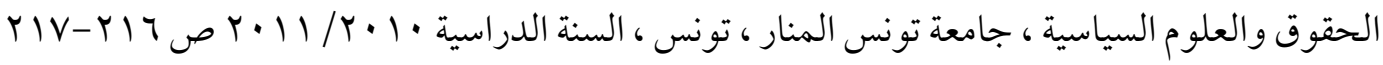

(4) Camila HABOUBI, , op , cit, no 575

(5) Ibid , no 582 
مصلحته ، فتبين له أوجه القصور في بوليصة التأمين التي يريد أن يتعاقد عليها"وتفصح له عن عدم كفاية الغطاء التأميني ، كما يمكن لها أن تحذره من شدة المخاطر التي يريد التأمين ضدها(r)، كذلك يجب عليها أن تقدم له تغطية للمخاطر التي لم يكن على علم بها أو لم يدرك فائدتها فيمكن لطالب التأمين الحضور إلى شركة التأمين لغرض الحصول على بوليصة تأمين و احدة فيخرج ومعه مجموعة كاملة من بو الص التأمين الأخرى (r). ومع ذلك فإن التزام المؤمن بالإبلاغ والمشورة مقيدًا بالضرورات التجارية ، حيث يكون هذا الالتزام بما لا يضر بمصالح المؤمن؛ لذلك لا يمكن أن يطلب من المؤمن والوسطاء أن يشوهوا منتجاتهم أو يو جهوا المستهلك إلى الأعمال المنافسة() . وهذا الدور المطلوب من المؤمن كمستشار لعميل التأمين يهدف إلى السماح للمؤمن له بالاستمتاع بشكل أفضل بعقد تأمين يتناسب مع وضعه الشخصي ، وقد يكون عدم الالتزام بهذا الدور مستتبعا عقوبات عليه ، كما هو الحال حيث قامت مسئولية شركة التأمين لأنها لم تحذر المشترك بعدم كفاية الضمان(م)، وبعدم مناسبته له(1). وقد ذهب البعض إلى ما هو أبعد من دور المستشار الاجتماعي بإلزام شركة التأمين على إخطار المؤمن له بالأخطاء التي يزعم أنه ارتكبها عند ملء الاستبيان وكذلك في حال عدم وجود رد على الاستبيان ، كذلك الحال لا يمكن لشركة التأمين المطالبة بمسئولية المؤمن له عن تصريح كاذب وذلك في الأحو ال التي يكون فيها خطأ المؤمن له صارخاله. و إذا كان المؤمن ملتزما بالمعلومات و المشورة إلى أن المؤمن له يجب أن يكون حريصًا

(1) Lamy assurances, 2005, op. Cit. p.23

(2) Yiqing Yang , op , cit ,p.248-249 - M. B. CRESCENZO-D'AURIAC,op , cit ,p.5

(3) Henriette E. Kameni, op , cit ,p.44 - Khalifi Taghzouti, et d'autres, op , cit, p.9

(4) Camila HABOUBI, op ,cit, no 589

(5) Cass. 1 Re civ. 12 novembre 1998, n 96-22.625, RGDA 1999, p. 426, note J. Kullmann (1 re espèce)

(6) S. Choisez, L'obligation d'information en matière d'assurance sportive, ou la cohérence bottée en touche, RCA 2003, chron. $n^{\circ} 3$

(7) Khalifi Taghzouti, et d'autres, op , cit, p.10 
على ألا يفاجأ بالأسرار الأكثر سهولة الواردة في العقد ، لذا يجب أن يكون لديه الحد الأدنى من اليقظة حيث إن فشل المؤمن كمهني في الوفاء بواجبه في المعلومات و المشورة لا يعفي العميل من واجبه في العناية والاجتهاد"ب(بعيدًا عن أن يقتصر على الدور السلبي ، يجب عليه

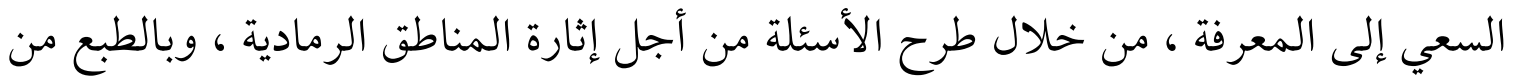
خلال قراءة وثائق المعلومات المقدمة له من المؤمن (").

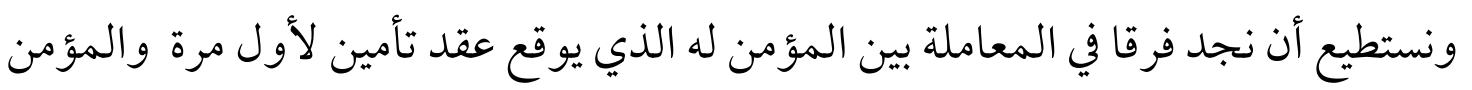

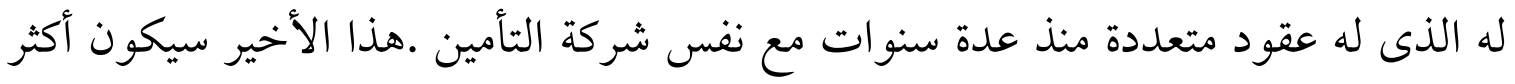

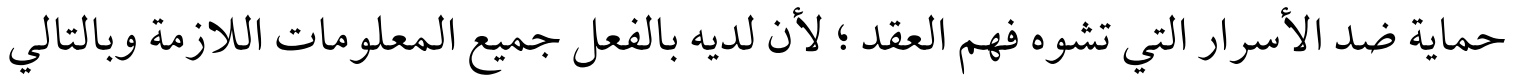
لا يجب أن يتم إبلاغه بنفس طريقة الشخص العادي"). الواقع أن عقد التأمين لم يعد كمينا يصطاد فيه القوى الضعيف وإنما يجب على شركة التأمين إظهار حسن نيتها من خلال مساعدة شريكها على تجنب بعض الأخطاء التي يرتكبها وبالتالي إبر امه عقد يناسبه وفقا لاحتياجاته .

ץ-تقديم المشورة في الواقع العملي : إن الواقع العملي بخصوص فكرة تقديم المشورة والنصح من شركة التامين أو وكلائها إلى العميل المحتمل بعيدا جدا عما سبق وأن سطرناه سابقا ، فالتزام شركات التأمين بتقديم المشورة يعتبر ضعيفا في ممارسات التأمين ، حيث إننا بعيدون عن لمس هذه الجنة المثالية في الحياة اليومية للتأمين بشكل عام وهذا الوضع ظاهر

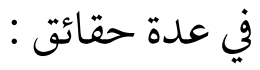

أول هذه الحقائق أن تطبيق شركات التأمين لهذا الالتزام محصور في ورقة المعلومات فقط والتي تحتوى عموما على إيجاز للأسعار والضمانات والاستثناءات ، وهذا الإيجاز لن يسمح

(1) Cass. 1 Re civ., 25 mars 2003, RCA 2003, comm. n 179

(2) Camila HABOUBI, op , cit, no 590

(3) Camila HABOUBI, op ,cit,no 591 
بإجر اء المقارنة مع منتجات الشركات الأخرى خاصة أن المؤمن له سوف تقتصر مقارنته فقط على سعر التأمين والذى يعتبر من وجهة نظره أهم بنود العقد"). ثاني هذه الحقائق أن الواقع العملي يظهر الكثير من الاستبعادات التي تكون موجودة في عقد التأمين ولا تحترم شركات التأمين التزامها بتحذير المؤمن له عن هذه الاستبعادات ، وهذا يؤكد فكرة أن شركة التأمين تقول أنها تغطى كل شيء وتفعل العكس (r). ثالث الحقائق هو وجود الكثير من الصعوبات التي تنشأ عن السياسة التسويقية لشركات التأمين والتي يبدو من خلالها أن شركات التأمين لا تسيطر على أغلب مبيعات التأمين ولا على طريقة العمل بهذا القطاع ، ومن هنا يستحيل تقديم المشورة للمؤمن له خاصة أن بائعي التأمين لهم هدف واحد هو الحصول على اشتراكات العديد من العملاء وذلك من أجل زيادة

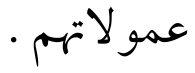
رابع الحقائق يأتي عن طريق حاملي الوثائق أيضا والذين يتحملون جزءا كبيرا من المسئولية ؛ وذلك لأنهم لا يقدمون أي وقت أو مجهود من أجل الاستماع إلى المشورة المقدمة من شركة التأمين بخصوص مخاطرهم . لا يخفي على الجميع فائدة الامتثال لهذا الشرط بحسن نية شركة التأمين في تقديمها المشورة للمؤمن له والتي قد تسهم في تحسين صورة شركة التأمين أمام العميل . الخلاصة أنه يجب على المؤمن أن يكون صادقا وعادلا في المعلومات التي يقدمها للعميل المحتمل ، كما يجب عليه تجنب الإدلاء بتصريحات خاطئة عن شركة التأمين من أجل الحصول على موافقة هذا العميل المحتمل ، فإذا قام بذلك فإنه يدلل على حسن نيته تجاه العميل المحتمل ، ليس هذا وفقط بل سوف يتجنب العقوبات الصارمة التي يفرضها

(1) Henriette E. Kameni,op , cit ,p.45

(2) Ibid 


\section{ع - حسن نية المؤمن عند إعداد الاستبيان}

الاستبيان عبارة عن وثيقة مكتوبة يضعها المؤمن أو من يمثله ، ويظهر فيها عدد معين من الأسئلة المتعلقة بخطر التأمين ، يلتزم المؤمن بإنشائه ليكون بمثابة دعم مادى للمؤمن له في تصريحاته ، حيث إن الغرض منه توجيه المؤمن له لتحسين بيانه وليس اعفاؤه من الكشف عن الظروف المعروفة له ذات الصلة بتقييم المخاطر. في أثناء إنشاء هذا الاستبيان يجب على المؤمن أن يظهر حسن نيته بكتابة نموذج أو طلب تأمين بشروط واضحة ودقيقة لا لبس فيها ؛ وذلك لأن الشك سيستفيد منه المؤمن له . لذلك يجب أن يكون الاستبيان مقروءا تماما ومفهوما من المؤمن له ، فيجب أن يكون بعبارات واضحة وبحجم خط واضح ، وبحيث يكون طرح الأسئلة فيه بطريقة بسيطة وغير مبهمة مما يتيح للمؤمن له تقديم إجابات مرضية ؛ لذا يجب أن يكون طرح الأسئلة واضحة ودقيقة بلغة يسهل فهمها ودون أن تسبب الصيغة المستخدمة إرباكا للمؤمن له عند الإجابة عليها() لذلك فإن المؤمن إذا طرح سؤالا غامضا على المؤمن له فلا لوم على الأخير إذا كانت إجاباته غامضة) ويجب أن توضع أسئلة الاستبيان بطريقة سليمة -غير معيبة ()- وشاملة لكل الظروف التي من المحتمل أن تؤدى إلى تقييم الخطر فتؤدى إلى كشف المؤمن له عن المعلومات المراد الكشف عنها(ه)، لذلك تعتبر الظروف غير المشمولة غير جوهرية ، حيث إن أسئلة الاستبيان

(2) 1re Civ., 15 octobre 1991, pourvoi n ${ }^{\circ}$ 90-11.725

(3) J. BONNARD, op, cit,,p.139

(4) 1re Civ., 9 décembre 1997, pourvoi n 95-21.758

(5) 2e Civ., 9 avril 2009, pourvoi n ${ }^{\circ} 08-14.624$

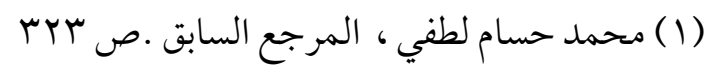


هي التي تحدد موضوع العقد وهي الحد الذى يجب أن يرتبط به ردود المؤمن له ، لذلك يجب أن يتم تقييم صدق ودقة البيانات التي تم الإدلاء بها وفقا للأسئلة المطروحة ، لذلك لا يمكن مساءلة المؤمن له لعدم تقديمه إجابات خارج نطاق هذه الأسئلة (1). كما يجب أن تكون أسئلة الاستبيان محددة ، وذلك حتى يستطيع المؤمن له الإجابة بطريقة محددة وسليمة ، وفي حال عدم إثبات شركة التأمين أن الأسئلة قد تم طرحها بطريقة سليمة ومحددة فلن تتمكن من إثبات التصريح الكاذب للمؤمن له(r).

ومن هذا المنطلق فقد أوصى الاتحاد الفرنسي لشركات التأمين بهدف تحسين لغة شركات التأمين بالاحتفاظ في ظل ظروف العمل ببعض المصطلحات التي يجب تفسيرها وهي: تفاقم المخاطر، المكافأة الرسملة ، المصادرة ، الضرر ، الحطام ، الاستثناءات ، السلف الحسابية المعاش السنوي ، المخاطر ، الخسارة والإنقاذ.

كما أوصى بضرورة تعريف بعض المصطلحات وهي: المصادقة ، البند ، الدمج ، الامتياز الانتفاع ، المخاطر المتعددة ، التنازل عن الرجوع ، الخصم ، العقوبة ، الحلول ، الأرباح و أخيرًا القيمة التي يحددها الخبير (r).

في الممارسة العملية غالبا ما تكون أسئلة الاستبيان في شكل أسئلة اختيار من متعدد ؛ وذلك للحصول من العميل المحتمل على إجابات أكثر وضو حا وأقل إرباكا .

\section{المطلب الثاني

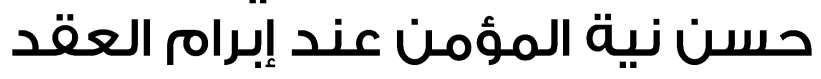

عند إبرام عقد التأمين يجب على شركة التأمين كونها مصمم العقد أن تثبت حسن نيتها باحترام كل الواجبات المنصوص عليها في القانون وبخاصة بخصوص كتابة عقد التأمين

(1) Civ. 1re, 7 déc. 1982, Bull. civ. I, $n^{\circ} 348$.

(2) -Civ. 1re, 24 juin. Arrêt $n^{\circ} 1205$ publié au Bull. civ. RGDA 1997. 1009, note L. FONLLADOSA ; civ. 3ème 28 mars 2007 arrêt n 297, RDI ; 2007. 223, obs. P. DES SUET.

(3) Lamy assurances, 2005, op. Cit. p. 32-34 
كتابة العقود بصفة عامة لها دور هام فيما يتعلق بإثبات وجود العلاقة التعاقدية بين الأطر اف المتعاقدة ، كما أنها تساعد في تقييم مدى صلاحية العقد المبرم أو على الأقل تكون نقطة دعم لحل النزاعات التي تنشأ بين الأطراف المتعاقدة ؛ فالكتابة تقدم مزيدا من الأمان

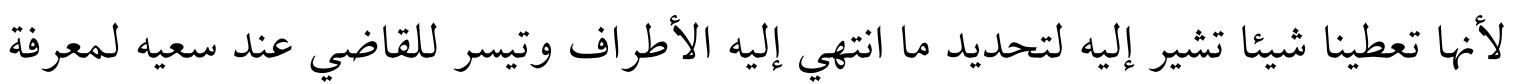

$$
\text { إرادتهم المشتركة . }
$$

وتظهر أكثر أهمية الكتابة في عقد التأمين ، فإلى جانب المهام السابقة للكتابة فإن الكتابة لها دور كبير في إعلام المؤمن له بحقوقه ، والتزاماته ، وتاريخ سريان العقد ، كما ستمكنه من التعرف على الشروط العامة لعقد التأمين والأحكام المحددة في العقد من أجل احترم الالتزامات التي تم التعهد بها ؛ لذلك هناك ضرورة حتمية لأن يكون عقد التأمين عقدا

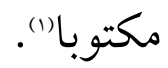

فالكتابة إذا كانت شرطا لإثبات العقود إلا أنها في مجال التأمين فإن هذا الشرط هو أكثر

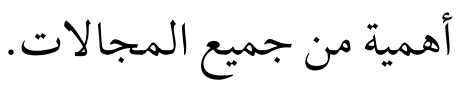

و الكتابة ليست كافية لأنها قد تكون غامضة ، والمعروف أن عقد التأمين وشروطه القياسية

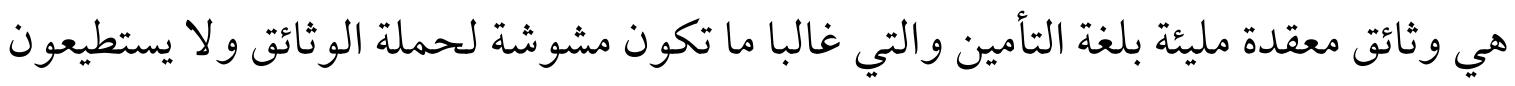

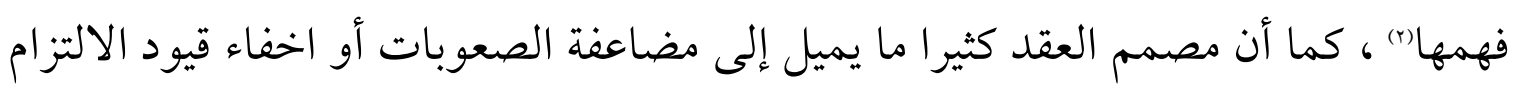

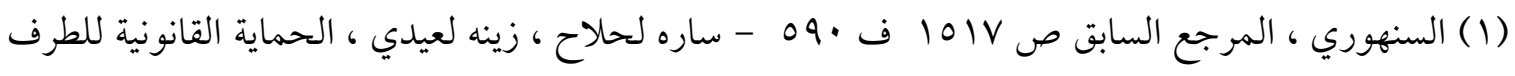

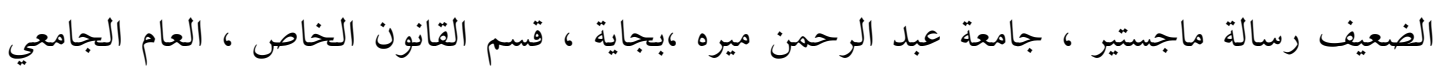

$$
r \varepsilon=r \cdot 1 T / r \cdot 10
$$

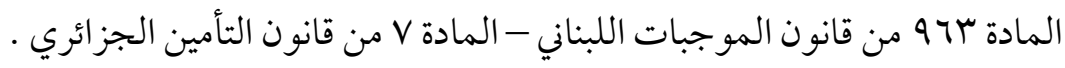

(2) Yiqing Yang , op , cit ,p.235. 
من أجل الاحتفاظ بإمكانية عدم تعويض المطالبات ، وهذه الممارسات كانت واسعة الانتشار وكانت تستحق الشجب حتى تدخل مشرعي التأمين بوضع الشروط التي يجب أن تكون مدرجة بعقد لتأمين للسماح بإعلام المؤمن له بشكل كامل ، وكذلك حظر الشروط

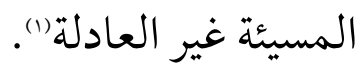

\section{أولا : إدراج الثروط الإلزامية لعقد التأمين}

عند كتابة عقد التأمين يجب على شركة التأمين إظهار حسن نيتها باحترام متطلبات قانون

التأمين فيما يتعلق بضرورة إدراج شروط العقد المنصوص عليها ().

وهذه الشروط أو البيانات هي التي تسمح للمؤمن له أن يكون على بينة بالشروط العامة

$$
\text { ولمحددة للعقد وضرورة احتر امها . }
$$

وإلزام المشرع بضرورة إدراج هذه البيانات في وثيقة التأمين لا يعتبر مساسا بالحرية

التعاقدية اذ إنه في هذه الحالة لم يلزم أطراف عقد التأمين بمضمون معين بل نص على العناصر الأساسية التي يجب أن يتضمنها العقد ، بعدها يحدد المتعاقدون مضمون العقد ؛ وذلك من أجل حماية الطرف الضعيف المتمثل في المؤمن له مستهلك لتأمين("). ولتسهيل قراءة هذه الشروط يحرص المؤمن على استعمال لغة بسيطة واضحة ومفهومة وهذا ليس بالسهل مع ما يقتضيه القانون و الطابع القانوني للعقد ، وغالبا ما يتم تكملة الشروط العامة بفهرس وشرح للمصطلحات التي بحاجة لذلك (s).

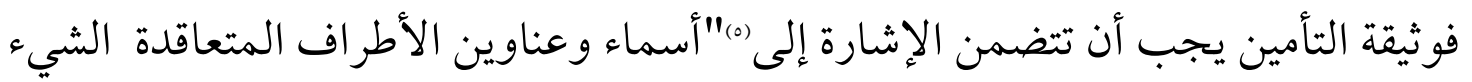

(1) PATRICE FIL , op ,cit, p.50

(2) Khalifi Taghzouti, et d'autres, op , cit, p.10

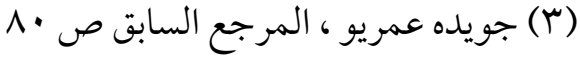

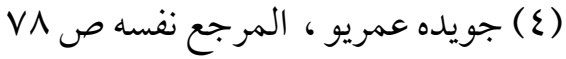

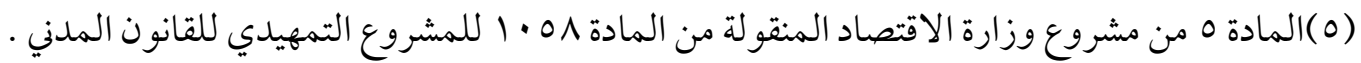

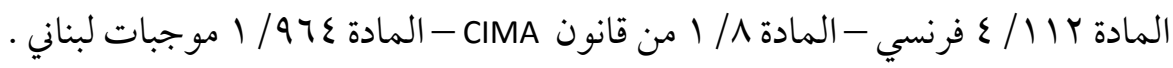


أو الشخص المؤمن عليه ، طبيعة المخاطر المضمونة ، اللحظة التي يتم فيها ضمان المخاطر

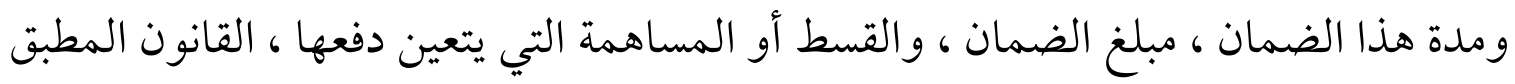
على العقد") وكذلك عنو ان المكتب الرئيسي للمؤمن .

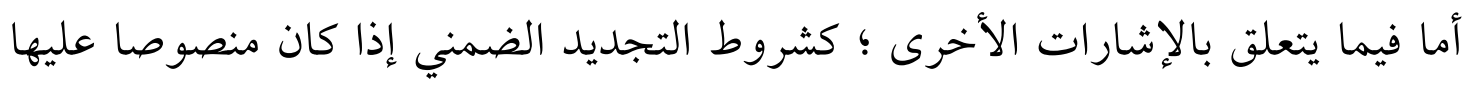

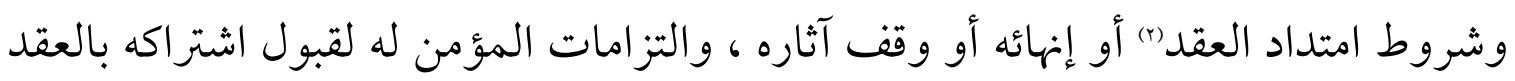
كالإعلان عن المخاطر الأولى ، أو الإعلان عن التأمين المتعدد وشروط هذه الإعلانات والتزاماته خلال العقد تنفيذ العقد ؛ كالإعلان عن تفاقم الخطر ، وكذلك شروط الإعلان الو اجب تقديمه في حال المطالبة والمدة التي يتم خلالها دفع التعويضات ، وأشكال الإنهاء

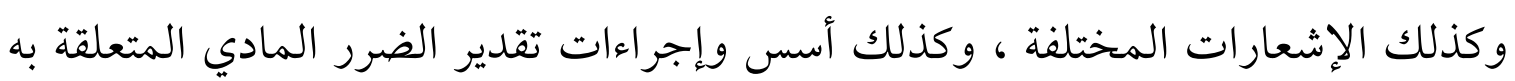
لتحديد مقدار التعويض ، كل هذه الإشارات تتيح للمؤمن له قراءة الشروط العامة للتأمين" (ه) .

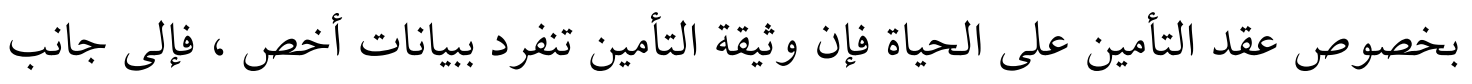
البيانات العامة يجب ذكر (s)|سم المؤمن على حياته ، ولقبه ، وتاريخ ميلاده ، واسم المستفيد ولقبه إذا كان شخصا معينا ، والحادث الذى يترتب على وقوعه استحقاق مبلغ التأمين

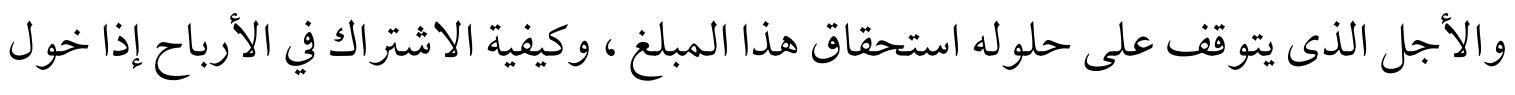

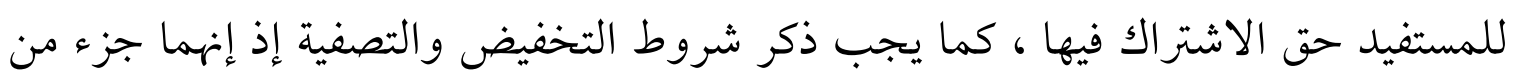

(1) تقرر المادة Y / / / ع من تقنين التأمين الفرنسي أنه يجب أن يحتوى عقد التأمين الإشارة إلى القانون المطبق

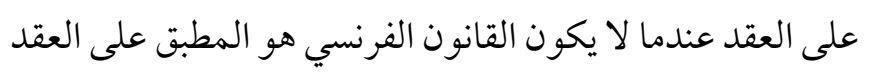

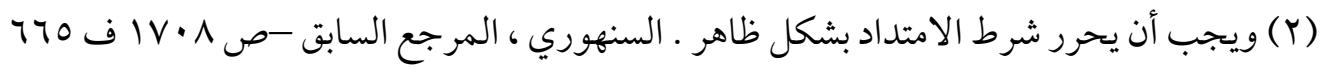
(3) Khalifi Taghzouti, et d'autres, op , cit, p.11 (ع) المادة ro من مشروع وزارة الاقتصاد -يقابلها المادة ب^^• من المشروع التمهيدي للقانون المدني- المادة

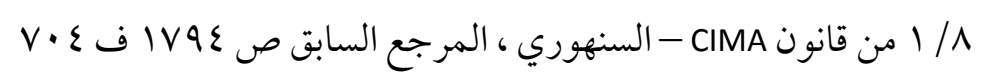




\section{الشروط العامة لهذا النوع من التأمين (1). ثانيا : حظر الشروط التعسفية}

عند صياغة عقد التأمين يجب على المؤمن أن يثبت حسن نيته من خلال تجنب إدراج بنود . . تعسفية وغير عادلة()،هذه البنود المحظورة ليست موضع تفاوض أبدا وذلك لأنها تؤدى إلى لي إلحاق ضرر كبير بالمؤمن له بصفته مستهلكا وتعمل على وجود خلل كبير بين حقوق

$$
\text { و التزامات أطراف العقد (r). }
$$

وإذا كان يحق للقاضي تعديل الشروط التعسفية غير العادلة أو الإعفاء منها للطرف المذعن باعتبار عقد التأمين من عقود الإذعان() إلا أن المشرع المصري لم يشأ أن يترك عقد التأمين لتطبيق هذه القواعد العامة والتي كان الفقه والقضاء سيصلان إليها حتما ، وإنما حرص على إيراد بعض النصوص التي يبدو من خلالها مدى وعيه الكامل بصفة الإذعان المتوفرة في عقد التأمين (0و أول هذه النصوص و أهمها هو نص المادة ro V من القانون المدني القاضي بأنه " يقع باطلا كل اتفاق يخالف أحكام النصوص الواردة في هذا الفصل( الخاص بعقد التأمين ) إلا أن يكون ذلك لمصلحة المؤمن له أو لمصلحة المستفيد " .فهذا النص

$$
\text { (1) (1) المادة س V من التقنين المدني المصري. }
$$

(2) Henriette E. Kameni, op , cit ,p.54 - Khalifi Taghzouti, et d'autres, op , cit, p.11

$$
\text { ror }
$$

(ع) المادة 9 \1 مدنى مصري - في فرنسا صلاحية الإعلان عن بند مسيء تكون بيد السلطة التنفيذية وكذلك القضاة ، لذلك فإن السلطة التنفيذية الفرنسية لديها الفرصة لإصدار مراسيم من مجلس الدولة والتي يجب على القاضي الرجوع لها لاتخاذ قراره كما يجوز للقضاة في بعض الحالات الاستثنئية عند وجود بنود مسيئة دون الاضطرار إلى انتظار مرسوم من مجلس الدولة ، إضافة إلى ذلك فإن توصيات لجنة الشروط التعسفية التي أنشت عام $19 V 1$ ساعدت في المكافحة الفعالة ضد الشروط المجحفة بعقد مند التأمين. PATRICE FIL , op , cit , p.53

$$
\text { (0) برهام عطا الله ، المرجع السابق ص } 10-77
$$


صريح في عبارته في عدم جواز الاتفاق على عكس الأحكام الواردة بخصوص عقد التأمين

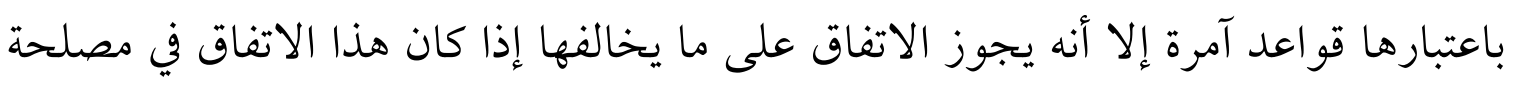
المؤمن له بحيث يتم منحه ميزات أكثر من المنصوص عليها في القانون ن). أما النص الثاني فهو خاص ببطلان بعض الشروط التي جرت شركات التأمين على إدراجها في وثائق التأمين وكان يترتب عليها حرمان المؤمن له من الضمان وقد نص على ذلى ذلك بالمادة

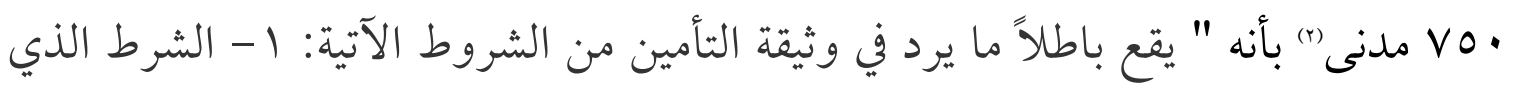

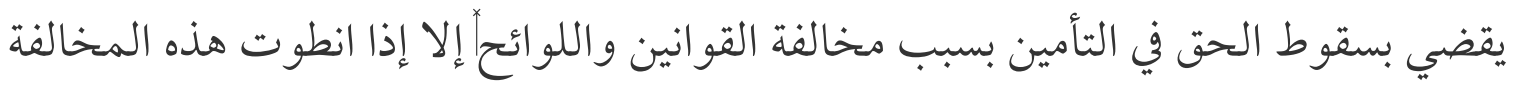

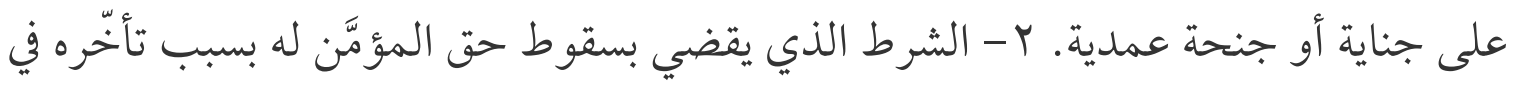

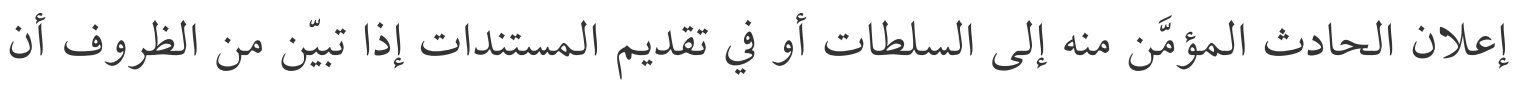

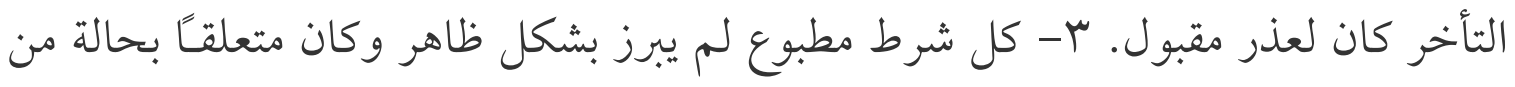

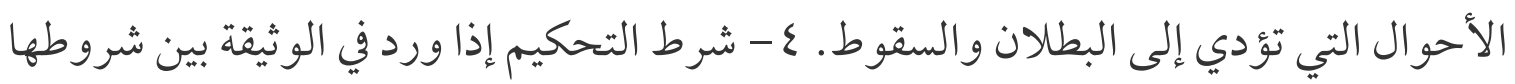
العامة المطبوعة لا في صورة اتفاق خاص منفصل عن الشروط العامة. 0 - كل شرط تعسفي

$$
\text { آخر يتبيّن أنه لم يكن لمخالفته آثر في وقوع الحادث المؤمّن منه." }
$$

وهذه النصوص الهامة لم ترد بين نصوص القانون المدني إلا لشعور واضعيه بحقيقة أولية أساسية وهي أن عقد التأمين عقد إذعان ويجب حماية الطرف المذعن وهو المؤمن له بكل الوسائل (ت) من خلال ما سبق يتضح لنا جليا أن احترام المؤمن لواجب حسن النية تجاه المؤمن له

(1) فلا يجوز أن يشترط المؤمن أن يبقى عقد التأمين ملزما للمؤمن له طوال مدته ـ السنهوري المرجع السابق ص

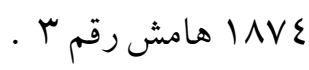

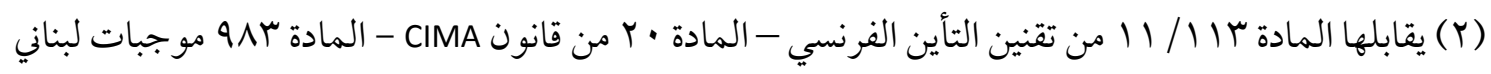

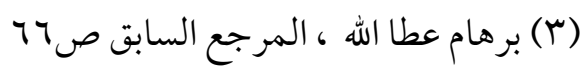


يظهر خلال إدراجه للمتطلبات الإلزامية لعقد الثأمين وبعدم إدراجه أي شروط غير عادلة ستعمل على خلق اختلال حقيقي بين طرفي عقد التأمين ، إضافة إلى ذلك فإن حسن نيته سيتضح جليا من خلال ولائه للمؤمن له عند صياغة عقد التأمين وهو ما سنتطرق له الأن : ثالثا- حسن نية المؤمن في صياغة عقد التأمين يتطلب القانون لإبرام عقد التأمن أن يكون هذا الإبرام في صورة مكتوبة(1) ولكن الكتابة في حد ذاتها ليست كافية ؛ لأنها قد تكون غامضة ، وكثير ا ما تميل شركات التأمين إلى مضاعفة الصعوبات أو إخفاء قيود الالتزام من أجل الاحتفاظ بإمكانية عدم تعويض المطالبات وذلك عن طريق كتابة وثائق بحروف دقيقة لا يتيسر قراءتها. هذه الممارسات كانت واسعة الانتشار وكانت تستحق الشجب حتى تدخل المشرع وحدد مجموعة من الشروط الواجب مراعاتها عند كتابة عقد التأمين ، فلكى يكون المؤمن حسن النية عند صياغة عقد التأمين يجب أن يكون هذا العقد مكتوب بأسلوب ظاهر ، باللغة

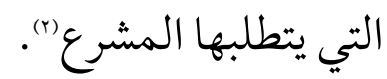
بالنسبة لعقد التأمين في القانون المصري يجب أن يكتب باللغة العربية لكن لا يوجد ما يمنع من كتابته بلغة أخرى غير العربية إذا اقتضى الحال ذلك(م).

(1) المادة Y / / / T من تقنين التأمين الفرنسي - يقابلها المادة V من قانون التأمين الجزائري - المادة / / I من قانون cima

ولا يشترط أن تكون الوثيقة مكتوبة في ورقة رسمية فقد جرت العادة أن تكون مكتوبة في ورقة عرفية . السنهوري ،

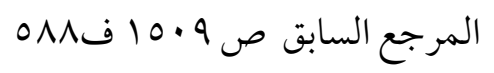

(Y) أوجب المشرع الفرنسي بالمادة r Y / / م من تقنين التأمين الفرنسي أن تكون كتابة عقد التأمين باللغة الفرنسية

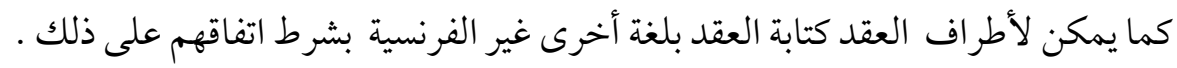
(r) لم يتعرض القانون المدني للغة التي يجب أن يكتب بها عقد التأمين ولكن مشروع وزارة الاقتصاد عرض لهذه سئه 
بخصوص صياغة عقد التأمين في القانون الفرنسي ، فإنه يجب أن تتم بطريقة واضحة ومفهومة وفي حال غموضها فإن الشك يتم تفسيره بالمعنى الأكثر ملاءمة للمستهلك (1). في الواقع يجب تقديم بنود العقود التي يقدمها المحترفون لغير المحترفين والمستهلكين وكتابتها بطريقة واضحة ومفهومة للمستهلك (()ولا يقصد أن تكون بنود العقد مفهومة للمستهلك على المستوى اللغوي و النحوي ، إنما أن تكشف الكتابة عن الأداء المطلوب من المستهلك الذى يشير إليه البند التعاقدي ، حتى يستطيع المستهلك تقييم العواقب الاقتصادية المترتبة عليه على أساس معايير دقيقة ومفهومة.

لتسهيل قراءة العقد من قبل المؤمن له يجب أن يكتب بخط ظاهر وواضح وبدون

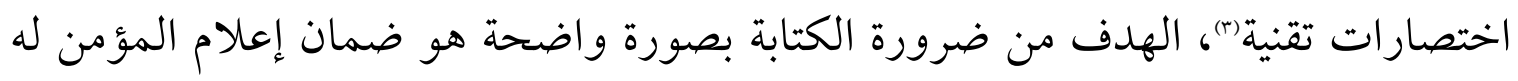
بمضمون لعقد وتحديد التزامات كل طرف من أطرافهة (s).

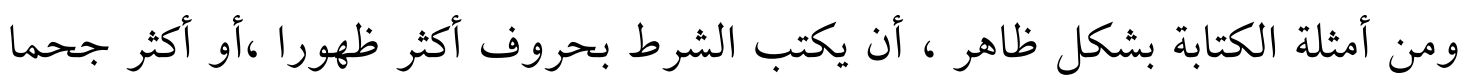

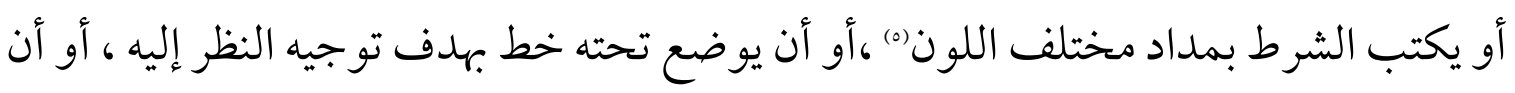

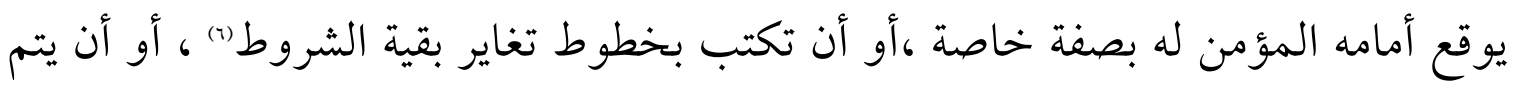

المسألة فأوجب أن تكتب وثيقة التأمين باللغة العربية إذا صت هذه المادة على أن " يجب أن تكتب وثيقة

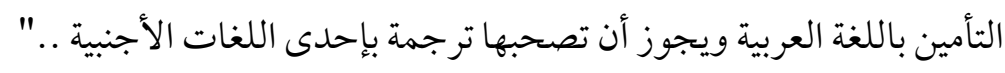

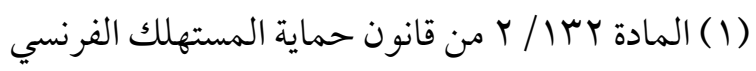

(2) Cass. Civ. I, 21 janvier 2003, $\mathrm{n}^{\circ} 00-13342$

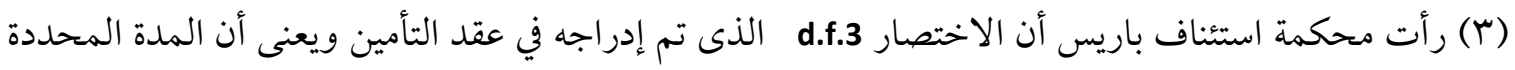

للعقد هي ب شهور لا يمكن الاحتجاج به ضد المؤمن له والذى كان يعتقد أن التعاقد لمدة سنة كاملة . Henriette E. Kameni,op, cit ,p.56

5 P.22 Cass. CiV. 23 Fevrier 1999, Resp.Civ.et Ass, $n^{\circ}$

$$
\text { (ع) جويده عمريو ، المرجع السابق ص } 1 \text { (1) }
$$

(5) Henriette E. Kameni,op , cit ,p.267

$$
\text { (7) السنهوري ، المرجع السابق ص س1 } 101 \text { هامش رقم }
$$


طبعها على مساحة ملونة ، أو أن يتم وضعها في إطار ، والأفضل والمستحسن أن يختار المؤمن أحد أساليب الصياغة هذه وليس جمعها كلها بوثيقة التأمين ؛ وذلك لأن تقييم القاضى قد يكون غير موات لهله (1). الخلاصة أنه يجب عند كتابة بنود العقد أن يكون هناك فرق مادى بين هذه البنود وبين

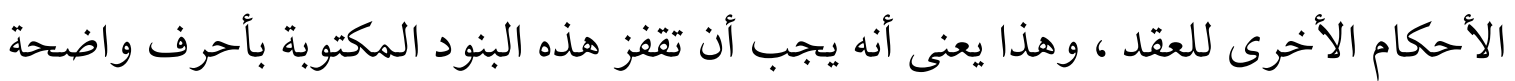
لتلفت نظر القارئ بمجرد رؤيتها بالعين المجردة ، وهذا يعنى أن تكون مرئية للوهلة

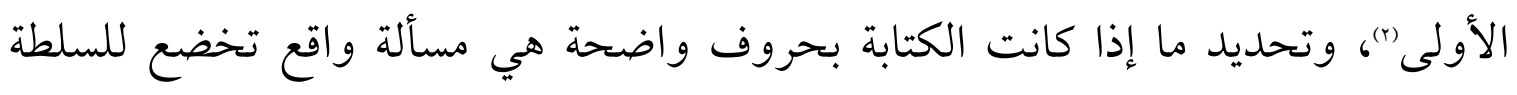
التقديرية لقاضى الموضوع). (ت). وإمعانا من المشرع في حماية المؤمن له ، وبسبب خطورة بعض الشروط فقد تطلب

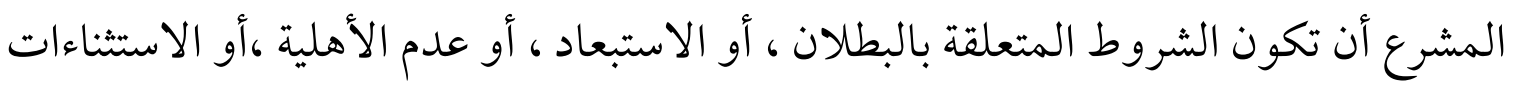

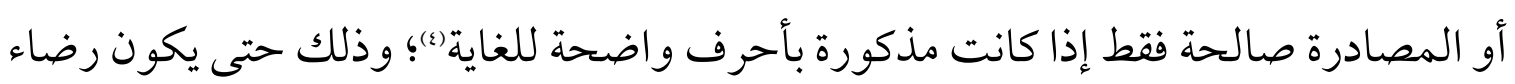

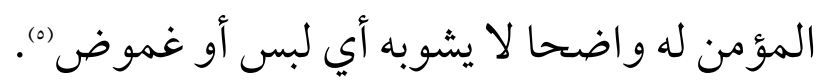
ومع ذلك فلا تنطبق هذه الشكليات على حالات البطلان والمصادرة والاستثناءات التي ينص عليها القانون ، إذا لا يعذر أحد بجههله بالقانون مندان. ففيما يتعلق بالاستبعادات وهي تلك المتعلقة بالمخاطر التي لا يضمنها المؤمن ، فإنه

(1) Henriette E. Kameni,op , cit ,p.57

(2) Ibid,p.267

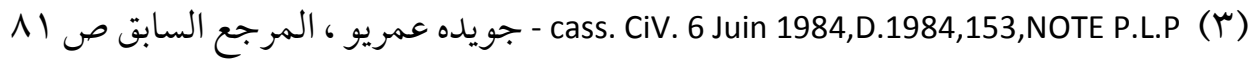

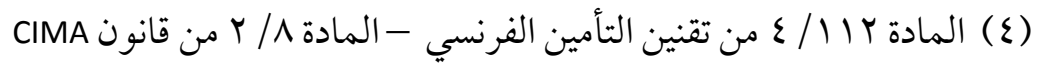

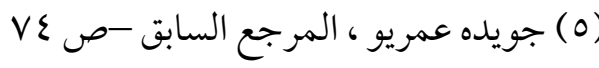

(7) و وعلى ذلك فإن شركة التأمين غير ملزمة بأن تحدد بالأحرف المرئية في العقد بطلان الإعلان الخاطئ المتعمد . Cass. Civ. I, 1er décembre 2013, $\mathrm{n}^{\circ} 89-12854$ 
يجوز لطرفي عقد التأمين الاتفاق على استبعاد بعض الأخطار من نطاق التأمين وقصر التغطية التأمينية على بعض حالات الخطر المؤمن منه ، وذلك تطبيقا لمبدأ الحرية التعاقدية الذى لفى لفي يسمح لأطر اف العقد بتحديد محله" (1). والاستبعاد قد يكون مباشر (()و هو الذى يتم بالتعبير الصريح من قبل شركة التأمين باستبعاد

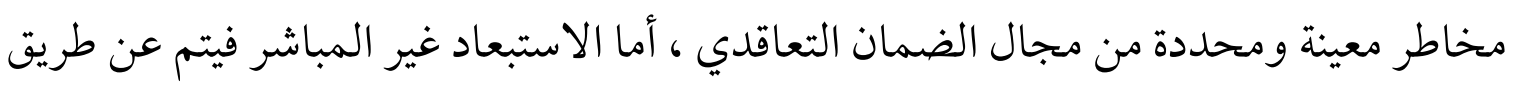
وضع المؤمن شروطا للخطر الذى يضمنه وبهذا فإن كل خطر لا يستوفي هذه الشروط يخرج

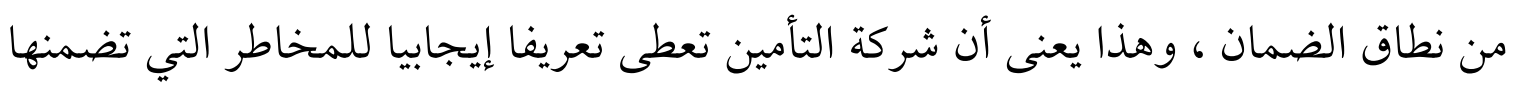

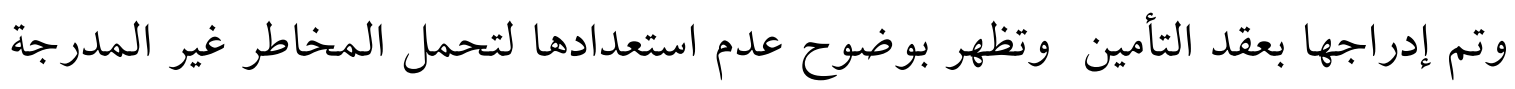
وغير المتفق عليها (r). الواقع أن شروط الاستبعاد كوسيلة للمؤمن للتخلص من تبعات الضمان الذى يلتزم به في

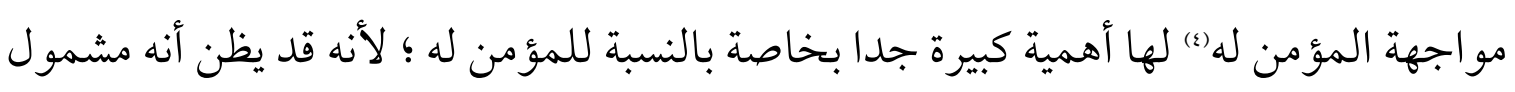

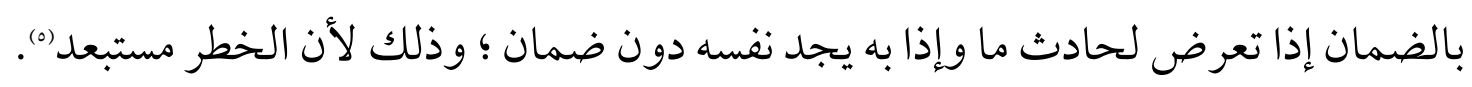
فيجب أن تكون شروط الاستبعاد واضحة محددة بطريقة تجذب انتباه المؤمن له ؛ وذلك

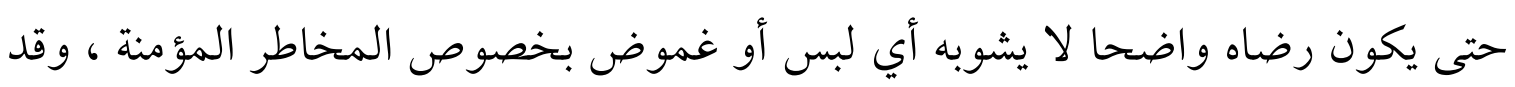

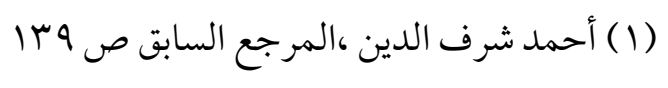

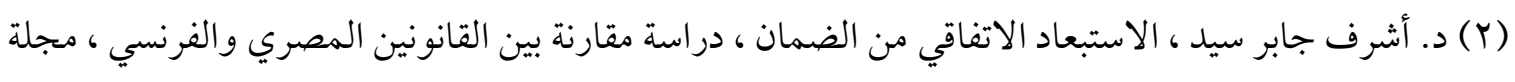

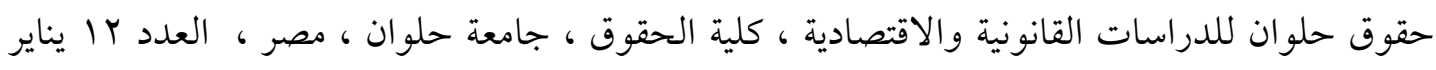

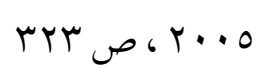

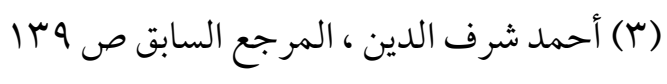

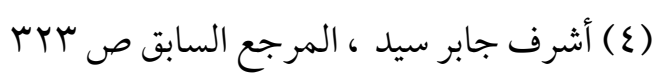

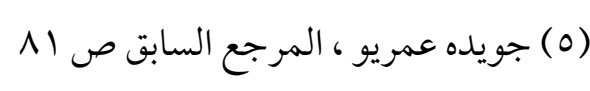


أجاز القانون الفرنسي مثل هذه الشروط بالمادة Y| || / ع من تقنين التأمين الفرنسي ولم يكتف بذلك بل نص صراحة بالمادة س| | / ا من ذات التقنين على صحة الاستبعاد مقررا ضرورة أن يكون الاستبعاد واضحا ومحددا (1) أن يكون مكتوبا بشكل بارز جد|(()ويكون إثبات وجود هذا الاستبعاد على عاتق شركة التأمين (r). ولا يكفي في عقود التأمين الجماعي للاحتجاج بشروط الاستبعاد أن يكون الشرط واردا في وثيقة التأمين ، لأن الغالب أن المشترك لا يطلع عليه ، بل يجب أن يرد هذه الشرط في مذكرة التبصير حتى يحتج به في مو اجهة المشترك (2). بل أن التشريع الصيني ذهب إلى ما هو أبعد من هذه الأحكام ، بخصوص كل عقود التأمين فقد قرر واجب الشرح والتفسير لشروط الاستبعاد على عاتق المؤمن له ؛ وذلك نتيجة حرمان المؤمن له من المعرفة المتخصصة وسوء فهم شروط العقد ؛ حيث إنها تكون فوق مستوى فهمه الذى يؤدى إلى تمثيل زائف لنيته الحقيقية ، فقرر بالمادة V من قانون التأمين الصيني ضرورة شرح وتفسير بعض بنود العقد ومنها شروط الاستبعاد كأحد الواجبات التي تقع على عاتق المؤمن تجاه المؤمن له وفي حال عدم شرح هذه الشروط فلن تسرى هذه

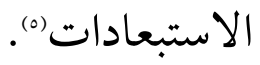

$$
\text { (1) أشرف جابر سيد، المرجع السابق ص ع (1) }
$$

(Y) وقد جاء بنص المادة r| / / / 1 " الخسارة والأضرار الناجمة عن قوة قاهرة أو التي سببها خطأ المؤمن له تكون

على عاتق المؤمن إلا ما استبعد في وثيقة التأمين استبعادا واضحا وأن تكون مكتوبة بشكل بارز جدا "

(3) Cass. Civ. I, 22 avril 1992, n` 89-16034; Cass. Civ. II, 21 février 2013, n` 12.17528

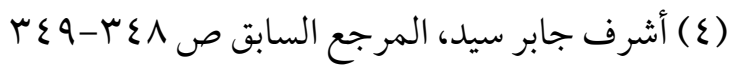

Cass. Civ.23 juin19989. B I.n 221 .D .1998.IR.P.175

(0) ظهر واجب التفسير لأول مرة في قانون التأمين الصينى لعام 1990 بالمادة V منه والتي قررت ضرورة شرح

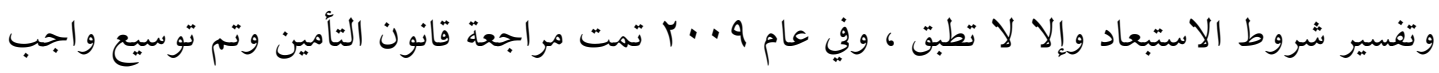


كما أن القضاء يتشدد في تفسير شرط استبعاد الخطر وعند وجود شرط غامض فإنه يفسره

$$
\text { لصالح المؤمن له" (1) - (1) }
$$

فيما يتعلق بالبطلان : فهو يتعلق بإحصاء جميع المواقف التي سئدى حدوثها إلى إبطال عقد التأمين ، وهو عقوبة خطيرة ترجع بالعقد بأثر رجعى إلى نقطة الصفر ، لذلك يجب أن

$$
\text { تكون واضحة ليستطيع القاضي تقريرها(). }
$$

فيما يتعلق بالسقوط : وهي الأحوال التي يترتب عليها حرمان المؤمن له من حقوق الضمان بسبب المخالفات والأخطاء التي يرتكبها ، فهذه الأحوال من أجل أن تؤخذ في الاعتبار بشكل صحيح يجب أن تكتب بشكل ظاهر وأكثر بروزا من البنود الأخرى ، ومن أمثلة هذه الشروط الشرط الذى يقضى بسقوط حق المؤمن له بسبب تأخره في إعلان الحادث المؤمن منه إلى السلطات العامة أو تأخره في تقديم المستندات (r). كذلك الحال بالنسبة لمدة عقد التأمين التي يجب أن تكون مكتوبة بأحرف واضحة للغاية()وبشكل ظاهر (1)(يستطيع المؤمن له التعرف عليها تلقائيا بمجرد النظر لعقد التأمين

$$
\text { التفسير ليشمل شروط الاستبعاد وجميع أسباب الإعفاء أو تقييد التزام الشركة. }
$$

Yiqing Yang, op , cit , p .235

(1) Cass. Civ.CH.14Fev. 1989.D .1989.IR 73 . 20 mars 1989 j.c.p.1989 iv.192 et lypu Ire ch .13janr.1989.s.1989.ir.163:164

تقرر محكمة التمييز الأردنية أن الشك حول وجود استبعاد الخطر من عدمه يفسر لمصلحة عدم الاستبعاد ( أحكام

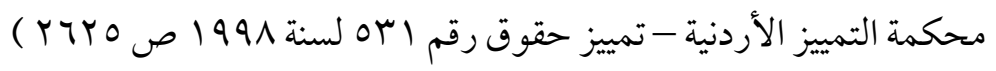

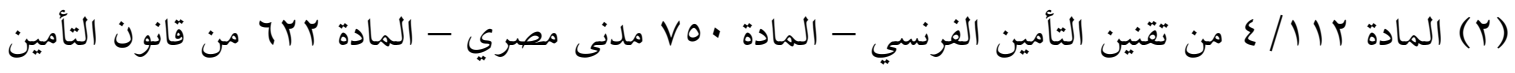

$$
\text { الجزائري }
$$

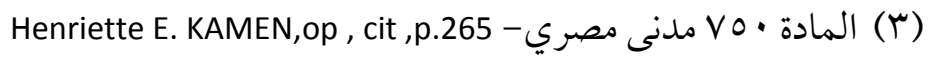

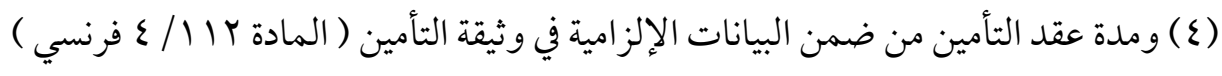

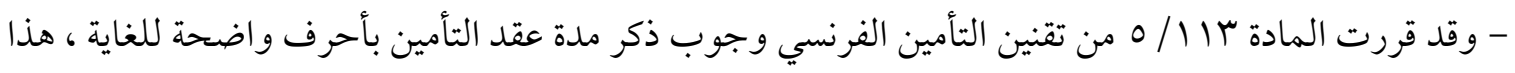


ويبرر هذا الاتساع في الإشارة إلى أن تكون مدة عقد التأمين مكتوبة بأحرف واضحة للغاية إلى الاهتمام الكبير الذى يكتسبه المؤمن له لمعرقة فترة تغطيته وبالتالي مدى مساهمته في

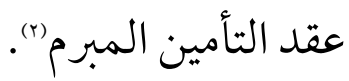
ويرتبط بمدة عقد التأمين فكرة امتداد عقد التأمين بعد انقضاء مدته الأصلية ، في القانون المصري لا يمتد عقد التأمين من تلقاء نفسه بل لابد لكى يمتد عقد التأمين أن يتم الاتفاق على امتداد العقد من تلقاء نفسه على أن يكون هذا الاتفاق محررا بوثيقة التأمين بشكل ظاهر (r)ويشترط لامتداد عقد التأمين أن يكون عقد التأمين من الأضرار وأن تكون مدته محدده ، وأن يكون هناك شرط صريح في وثيقة التأمين يقضى بامتداد العقد من تلقاء نفسه بعد انقضاء مدته المحددة ، كما يشترط أن تنقضي مدته الأصلية بأكملها ، وأن يسكت المؤمن له فلا يعارض في الامتداد()فاذا تو افرت هذه الشروط امتد العقد لمدة سنة واحدة فقط ؛ وذلك حتى لا يجد المؤمن له نفسه مقيدا تلقائيا بالعقد لمدة طويلة (ه). فإذا لم يوجد الاتفاق على الامتداد بشكل ظاهر فلا امتداد للعقد ، ويبرر ذلك بحماية

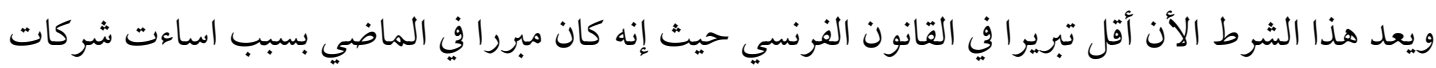
التأمين التي استحوذت على عملائها بالتزامات طويلة الأجل لكن الأن المشترك أصبح لديه خيار الإلغاء السنوي وبالتالي لا يمكن تقييده بعقد تأمين لمدة طويلة .

( ) وقد قررت المادة V من مشروع وزارة الاقتصاد أنه " يجب أن تكون مدة التأمين مكتوبة بشكل ظاهر في الوثيقة وتبدأ من ظهر اليوم الذى تم فيه العقد وتنتهى في ظهر اليوم الأخير ما لم يتفق على غير ذلك "

(2) Henriette E. Kameni,op , cit ,p.57

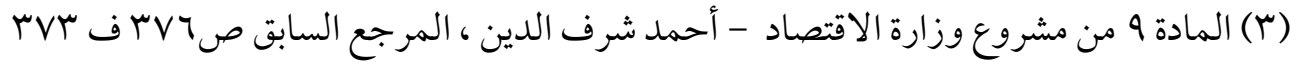

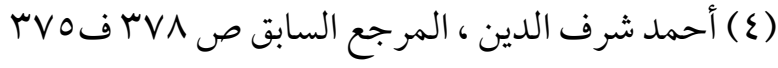

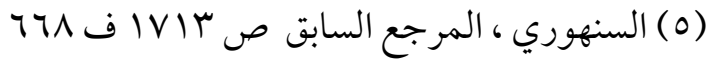


المؤمن له من مفاجأته لمجرد سكوته بامتداد عقد (1) قد لا يريد الانضمام إليه.

\section{المطلب الثالث \\ حسن نية المؤمـن في تنفيذ عقد التأمين المين}

لا تقتصر العلاقة بين المؤمن والمؤمن على إبرام العقد ـ في الواقع يتطلب تنفيذ العقد اتصالات متكررة بين الطرفين ، فيجب على المؤمن أن يظل حسن النية أثناء سريان عقد التأمين وحسن نيته هذا يستوجب ضرورة إبلاغ المؤمن له بأي خرق أو موقف معين سيترتب عليه التأثير على حقوقه ، وهذا هو مما يسمى التواصل بين المؤمن والمؤمن له . كذلك فالمؤمن يضع تحت أمر المؤمن له جميع إمكانياته وكل استعداداته من أجل تغطية الخطر المؤمن منه ، وفي حال تحقق هذا الخطر فيجب عليه أن يكون حسن النية من خلال التزامه بأداء مبلغ التأمين المستحق وفقا لشروط العقد ، ودون وضع العوائق أمام حصول

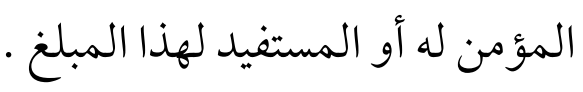
كما أن المؤمن بحصوله على البيانات والمعلومات المتعلقة بضمان المخاطر سواء كانت بيانات شخصية أو بيانات موضوعية ، يصبح أمينا على هذه المعلومات ولا يجب أن يكشف عنها للغير باعتبارها أسرارا تخص المؤمن له.

وسوف نقوم بدراسة تفصيلية لالتزامات المؤمن في تنفيذ عقد التأمين على النحو التالي :

أولا : حسن نية المؤمن في الوفاء بواجب الاتصال بالمؤمن له .

إذا كان القانون قد فرض على المؤمن له أن يكون حسن النية عند تقديم التزام المعلومات المتعلقة بالمخاطر سواء قبل إبرام عقد التأمين أو في أثناء سريان وتنفيذ عقد التأمين ، فإننا سنجد أن المشرع قد فرض على المؤمن بعض الالتزامات المتعلقة بواجب الإعلان والإخبار من قبله وذلك قبل إبرام عقد التأمين كما سبق أن رأينا سابقا ، كما أن المشرع قد فرض عليه

(1) السنهوري ، المرجع نفسه ص99 IV ف770 
أيضا بعض الالتزامات المتعلقة بإعلام المؤمن له ببعض الحقائق والأمور التي ممن المحتمل أن تؤثر على سريان عقد التأمين وبالتالي تؤثر على حقوق طرفي العقد . فيجب على المؤمن أن يكون حسن النية عند قيامه بو اجبه بإخبار المؤمن له بحقائق معينة ويكون هذا الإخبار عن طريق مختلف الإشعارات والإخطارات الرسمية التي تشكل التزام المؤمن بالو لاء في تقديم معلو مات للمؤمن له أثناء تنفيذ عقد التأمين" . فيجب أن يكون المؤمن عادلا للمؤمن عليه خلال فترة عقد التأمين بإعلامه بأي حالة تتخلل عقد التأمين وتؤثر على الضمان وذلك لضمان الحماية منها (). ونتيجة لذلك يتعين على المؤمن إظهار حسن نيته وصدقه تجاه المؤمن له في حال تخلف المؤمن له عن سداد أقساط التأمين ، وكذلك في كل حالة يجد فيها أن المؤمن له قد انحرف عن الإطار المحدد له بعقد التأمين وذلك بلفت نظره لذلك ، كما يجب على المؤمن أن يزود المؤمن له بالمواعيد المحددة لتجديد أو امتداد عقد التأمين ؛ وذلك حتى يستطيع المؤمن له اتخاذ قرارهوفقا لما ير اه صو ابا له. 1 - الإشعار المتعلق بدفع قسط التأمين. كانت شركات التأمين تلجأ في حال عدم وفاء المؤمن له لقسط التأمين لوضع شروط في وثائق التأمين من شأنها أن تخالف القواعد العامة التي توجب إعذار المؤمن له لدفع القسط وفي حال عدم الوفاء تطلب من القضاء إما التنفيذ العيني أو الفسخ ، حيث كانت تضع شروطا تيسر الإجراءات بالنسبة لها بحيث يصبح المؤمن له تحت رحمتها ، وكان من ضمن هذه الشروط أن تشترط إعفاءها من الإعذار وألا تتقيد بمو اعيد لوقف العقد عند عدم سداد قسط التأمين ، وكان نتيجة ذلك أن المؤمن له يتفاجأ قبل أن ينبه عليه بدفع القسط المتأخر بأن

(1) PATRICE FIL , op , cit , p.33

(2) Ibid , p.83a 85 
التزامه موقوف وقد تحقق الخطر فيضيع عليه حقه في مبلغ التأمين المتفق عليه بعقد التأمين (1).

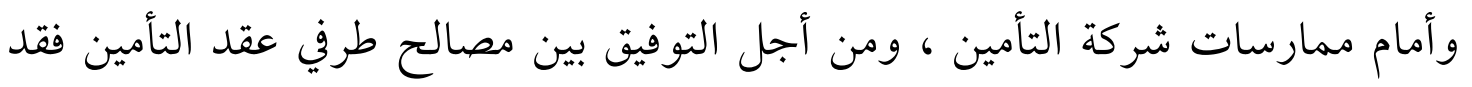

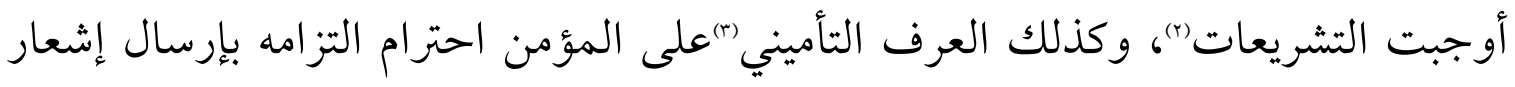
للمؤمن له في حال عدم سداد قسط التأمين . ويعد هذا الالتزام من النظام العام (i) وبالتالي لا يجوز الاتفاق بين المؤمن والمؤمن له على له أي شرط يخالف هذا الالتزام ، وإن كان من الجائز الاتفاق على شرط يخالفه بشرط أن يكون لمصلحة المؤمن له لم. فعدم أداء قسط التأمين يجيز لشركة التأمين أن تنذر المؤمن له بكتاب موصى عليه

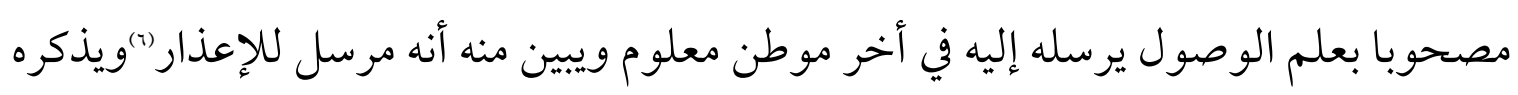
بتاريخ استحقاق القسط وبالنتائج المترتبة عليه .

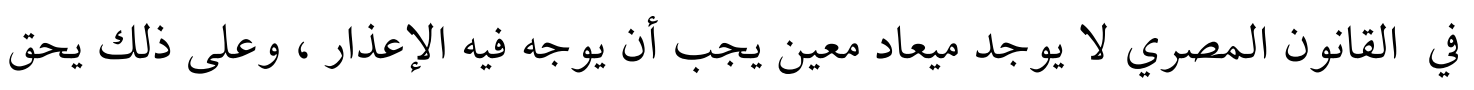

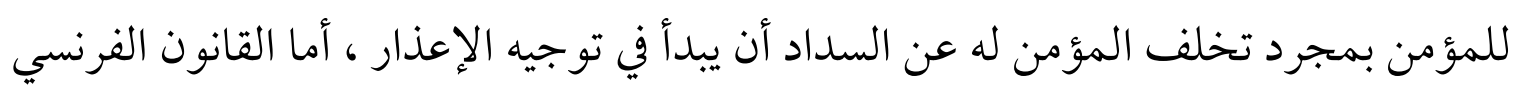
فيجب على شركة التأمين أن ترسل الإعذار بعد مضى عشرة أيام من تاريخ استحقاق القسط (N) وهذه المدة فيها تراضى مقصود به حماية المؤمن له الذى قد تو اجهه صعوبات مالية

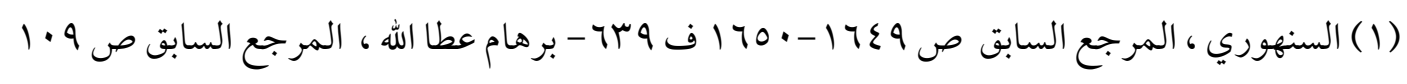

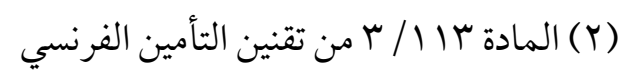

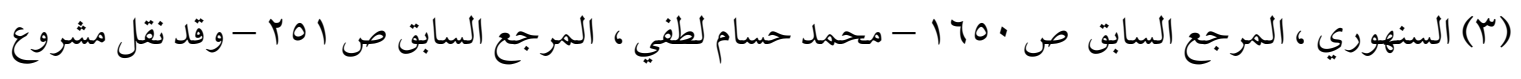
وزارة الاقتصاد هذا العرف التأميني بالمادة 19 من هذا المشروع المابع

(4) Henriette E. Kameni, op , cit ,p.60 -Khalifi Taghzouti, et d'autres, op , cit, p.18

$$
\begin{aligned}
& \text { (0) السنهوري ، المرجع السابق ص 1701 } 170
\end{aligned}
$$

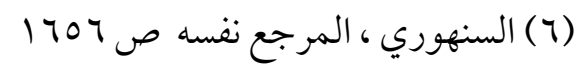

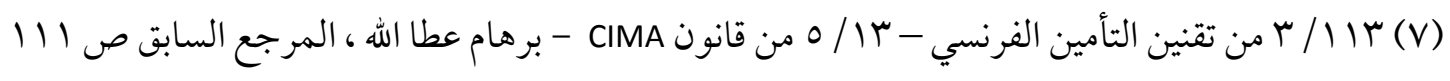




\section{محتملة أو مجر د سهو عن سداد القسط (1).}

ولتوجيه الإعذار بكتاب موصى عليه بعلم الوصول أهمية كبيرة حيث إن تاريخ هذا الإعذار يعتمد عليه في استمرارية العقد والضمان الممنوح من قبل المؤمن ، ويترتب عليه كذلك أن يصبح قسط التأمين واجب الدفع في موطن شركة التأمين ، كما أنه يقطع المدة التي تسقط بها دعاوى المطالبة بالقسط من اليوم التالي لتاريخ إرسال الإعذار يبدأ سريان الميعاد الذى بمروره يوقف سريان عقد التأمين وهذا الميعاد مقداره ثلاثون يوما ، وفي خلال مدة الثلاثين يوما المذكورة فإن عقد التأمين يظل ساريا وتضمن شركة التأمين الخطر المؤمن ضده ونرى أن هذه المدة طويلة نسبيا وفيها ظلم لشركات التأمين وبخاصة إذا حدثت المخاطر ، كما أن فيه اختلال كبير في التوازن بين مصالح طرفي عقد التأمين وأن المشرع قد ضحى بمصالح شركات التأمين لصالح حفاظه على تغطية المخاطر المؤمنة . وبمرور ثلاثين يوما من تاريخ الإعذار الرسمي دون أن يقوم المؤمن له بسداد القسط المطالب به فإن الضمان يتم تعليقه تلقائيا ، فيوقف العقد(r) لمدة عشرة أيام فإذا انقضت العشرة أيام دون السداد فيكون لشركة التأمين الحرية في إنهاء العقد إذا رغبت في ذلك (ع).

(1) Henriette E. Kameni, op , cit ,p.60 -Khalifi Taghzouti, et d'autres, op cit, p.18

$$
\text { (Y) (Y) المادة } 19 \text { من مشروع وزارة الاقتصاد }
$$

(r) ومعنى وقف العقد أن المؤمن يتحلل خلال فترة الوقف من ضمانه في حال وقوع الكارثة المؤمنة ، أما بخصوص القسط فيبقى ملتزما بدفعه عن مدة الوقف ولا يتحلل من التزامه إلا إذا فسخ العقد ( السنهوري المرجع السابق ص 1709 - • 177 - برهام عطا الله ، المرجع السابق ص r 11 )

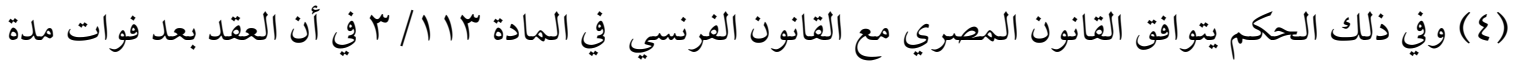
• بيوم من تاريخ الإعذار يتم وقفه لمدة عشرة أيام فإذا انقضت العشرة أيام من تاريخ الوقف فيجوز للمؤمن أن يطلب فسخ العقد في أي وقت بعد انقضاء هذا الميعاد وذلك إلى يوم حلول القسط الجديد. 
من خلال حساب المواعيد المتعلقة بالإعذار يتبين لنا أن الإعذار هو تحذير من المؤمن للمؤمن له ضد عواقب عدم سداده قسط التأمين ، و المؤمن له غير ملزم بالدفع لكنه سيدرك من الإعذار الأثر الحالي والمستقبلي لعدم دفعه على استمرارية العقد ؛ لذلك يجب إرساله كإشعار رسمي مذكور فيه مقدار القسط وتاريخه والنتائج المترتبة على عدم الدفع ومواعيد وقف العقد والحق في الفسخ. وهذه الأحكام المتعلقة بسداد القسط غير مطلوبة في عقود التأمين على الحياة فلا يشترط على المؤمن التواصل مع المؤمن له وفقا للشروط المنصوص عليها في التأمين على غير الحياة . وتنبع هذه الخصوصية من طبيعة هذا النوع من العقود وذلك لأن هذا النوع من التأمين يتبنى قواعد الادخار والرفاهية الاجتماعية ومجاله هو وجود الفرد كخطر ومن هنا وجد اتجاه مستقر في نطاق هذا التأمين مقتضاه أن يكون التزام المؤمن له بدفع القسط اختياريا (1). فمتى تم إبرام عقد التأمين على الحياة فإن المؤمن له يكون ملتزما بدفع القسط الأول على الأقل ولا يستطيع التحلل من دفعه(() إذا تأخر في دفعه فيجوز للمؤمن أن يجبره على ذلك فيجب كما في سائر العقود أن يبدأ المؤمن بإعذار المومن له بالدفع ويكون الإعذار بكتاب مسجل موص عليه مصحوب بعلم الوصول وفق ما سبق شرحه ، فإذا لم يكن للإعذار نتيجة فإنه بمرور الثلاثين يوما فلا يوقف عقد التأمين على الحياة كما يوقف سائر عقد التأمين وإنما يكون للمؤمن الحق في إنهاء العقد ، فإذا كان المؤمن له قد دفع ثلاثة أقساط سنوية على الأقل

(1) برهام عطا الله ، المرجع السابق ص 110

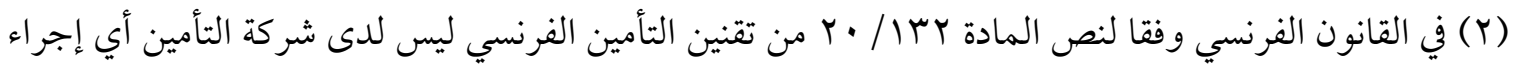
للمطالبة بالقسط ولا يمكن معاقبة المؤمن له بسبب عدم دفعه القسط ، ولا يكون لشركة التأمين بعد إرسال الإعذار ومرور مدة الأربعون يوما سوى إنهاء العقد أو تخفيضه إذا توافرت شروط التخفيض . 
فإن المؤمن لا ينهي العقد")بل يخفض قيمته طبقا لأحكام التخفيض الواردة بالمادة • V7 من التقنين المدني المصري أو أن تتم تصفية العقد وفقا لأحكام المادة بال من التقنين المدني

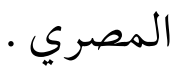

يوجد كذلك الكثير من الحالات التي تتطلب إرسال إشعار ات وإخطارات من قبل المؤمن له للمؤمن خاصة فيما يتعلق بعدم احترام المؤمن له لبنود العقد المتفق عليها. r - فيما يتعلق بالإشعارات الرسمية التي قد تتعلق بعدم احترام المؤمن له لبنود العقد المتفق عليها مسبقا ، فإن هذه الإشعارات لا تندرج تحت شرط وإنما تأتى من ممارسات محددة لشركات التأمين(r)لذلك كلما كان المؤمن يعرف أن المؤمن له لم يعد يمتثل للبنود المتفق عليها بالعقد وإنما بدأ في خرقها، هذه المعرفة من قبل شركة التأمين قد تنتج عن الملاحظات أثناء الزيارات أو المعلومات أو أي وسيلة أخرى ، هنا يجب علي المؤمن أن يطلب منه الكف عن هذا الخرق لبنود العقد والعودة إلى الحدود المحددة بالعقد واحترام هذه البنود المحددة مسبقا مع ضرورة إبلاغه بالنتائج المترتبة على هذه الخروقات وبعو اقب الاستمرار في هذا الخرق على استمرارية العقد (r).

يمكن أن يتم هذا التدبير في حال تعديل العقد حيث يستمر المؤمن له في التصرف باعتباره ضمن إطار العقد الأولى ؛ لذلك يجب على المؤمن لفت انتباهه إلى التغيرات التي حدثت وكذلك عواقبها على استمرار العقد. وقد يكون عواقب عدم امتثاله وقف العقد أو إنهائه ومصادرة الأقساط التي تم دفعها. يجب في جميع الأحوال أن يتم هذا الاتصال بالمؤمن له وفقا للمعايير المطلوبة لتعكس 
حسن نية شركة التأمين في إدارتها لعقد التأمين في هذه المرحلة .

ץ- تظهر أهمية الإخطارات الرسمية أكثر بخصوص امتداد عقد التأمين بعد انتهاء مدته

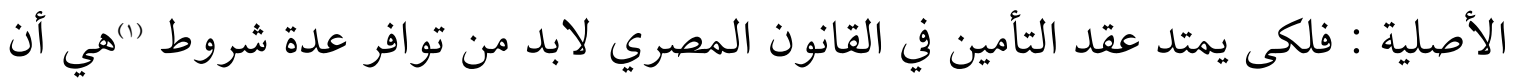

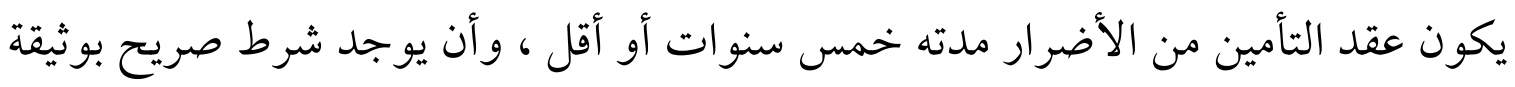

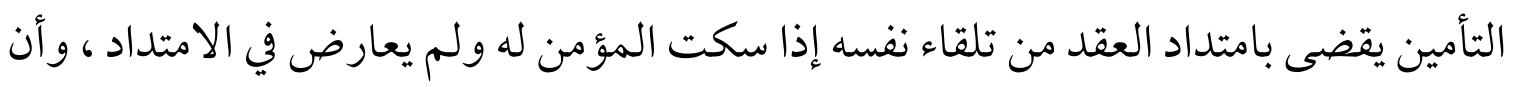

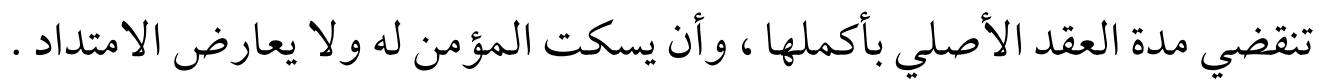
في حال معارضة المؤمن له للامتداد فيجب أن تتم هذه المعارضة بكتاب موصى لمعى عليه بعلم الوصول قبل انتهاء المدة الأصلية بثلاثين يوما على الأقل أو قبل انتهاء السنة التي امتد فيها

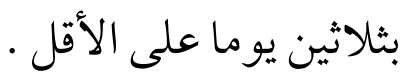

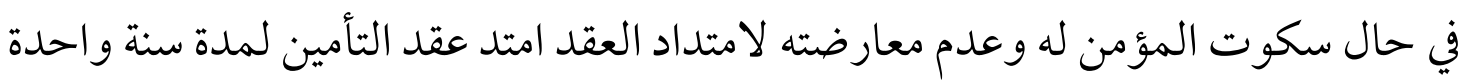
وذلك حتى لا يجد المؤمن له نفسه مقيدا تلقائيا بالعقد لمدة طويلة.

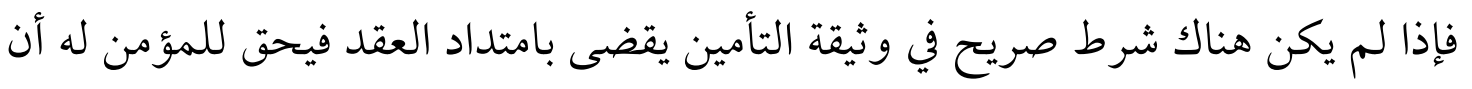
يعرض الامتداد على المؤمن بخطاب مسجل بعلم الوصول يوجهه إليه في مركزه الرئيسي وبشرط أن يكون المؤمن له قد قام بأداء الأقساط المستحقة عليه عن المدة الماضية ، فإذا أراد المؤمن رفض الامتداد فيجب أن يقوم بإبلاغ المؤمن له بعدم مو افقته على طلب الامتداد خلال خمسة عشر يوما من وصول كتاب المؤمن له المحتوى على طلب الامتداد"). أما القانون الفرنسي فإن معظم عقود التأمين اختارت فكرة التجديد الضمني للعقد ولفئ ولفترة

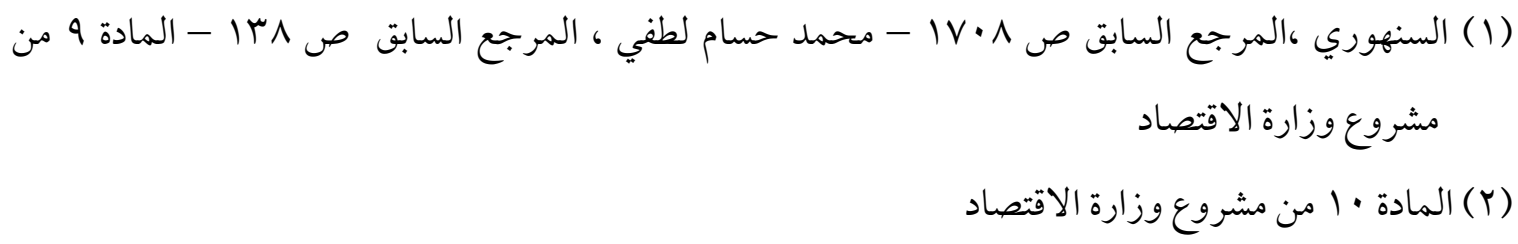


لا يمكن أن تتجاوز عاما واحد').

فإذا كانت فكرة انتهاء عقد التأمين أمرا مؤسفا لشركة التأمين التي تفقد عميلها ، كذلك فهي فكرة مزعجة للمؤمن له الذى سيجد نفسه غير مغطى تأمينيا ابتداء من هذا التاريخ ؛ لذلك نجد أن عقود التأمين في معظم الأحيان تنص على تجديدها ضمنيا في نهاية مدتها . ففي نهاية عقد التأمين يجب على شركة التأمين أن تخطر المؤمن له أو الشخص المسئول عن دفع الأقساط() قبل نهاية فترة قسطه بخمسة عشر يوما أو حسب المدة المتفق عليها بشروط التجديد الضمني وتذكره بإمكانية ممارسته للحق في إنهاء شرط التجديد الضمني ويموعد ممارسته هذا الحق ، فإذا لم يستخدم المؤمن له هذا الحق اعتبر العقد مجددا لمدة سنة و احدة. وفي حال ما إذا كانت مدة التجديد الضمني أكثر من سنة واحدة ، وهذا يتعارض مع أحكام القانون ، فإن المؤمن له وكذلك المؤمن يحق له إنهاء عقد التأمين دون تعويض كل عام بشرط أن يكون هذا الإنهاء بإشعار مسجل بعلم الوصول قبل نهاية السنة بستة شهور على الأقل . وفي حال تو افق مدة التجديد الضمني مع أحكام القانون فيحق للمؤمن له اختيار إنهاء العقد في نهاية فترة السنة المجددة عن طريق إرسال خطاب مسجل بعلم الوصول لشركة التأمين قبل شهرين على الأقل من تاريخ الاستحقاق(') . ع - كما تظهر أهمية الإخطارات الرسمية بخصوص فكرة تعديل عقد التأمين ، فإذا كان القانون لا يجيز إجراء أي تعديل أو إضافة في عقد التأمين إلا بمقتضى ملحق لوثيقة التأمين

$$
\begin{aligned}
& \text { (1) المادة r 1/ / / 10 من تقنين التأمين الفرنسي }
\end{aligned}
$$

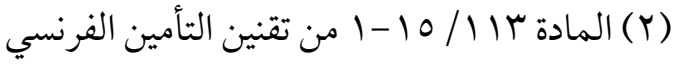

$$
\begin{aligned}
& \text { (ץ) المادة ץ|| / / ع ا من تقنين التأمين الفرنسي }
\end{aligned}
$$


و التأشير به على هامش الوثيقة بشرط توقيع المؤمن ، كذلك يجوز أن يكون التعديل بكتاب مو صى عليه مصحوب بعلم الوصول يتبادله طرفي عقد التأمين ".

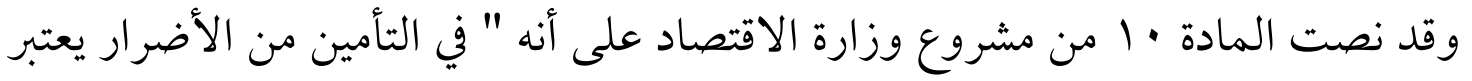
مقبو لا الطلب المرسل بكتاب موصى عليه مصحوب بعلم وصول من المؤمن له إلى المؤمن في مركز إدارته الرئيسي متضمنا امتداد العقد أو تعديله وهذا بشرط أن يكون المؤمن له قد قام بأداء الأقساط المستحقة عن المدة الماضية وذلك ما لم يقم المؤمن بإبلاغ المؤمن له خلال

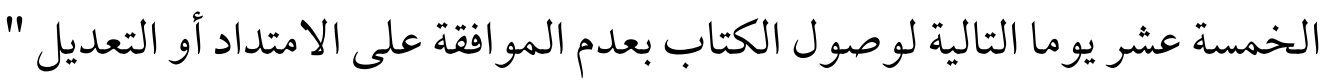
أما القانون الفرنسي فيفترض توافر مجموعة من الشروط لتعديل عقد التأمين من قبل

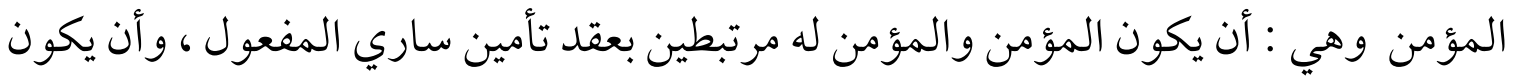

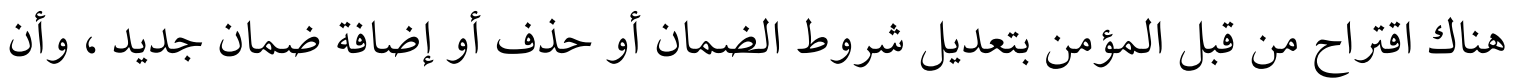
يقوم المؤمن بإخطار المؤمن له كتابة بواسطة خطاب مسجل موصى عليه بعلم الوصول ، وفي هذه الحالة لن يتم تعديل العقد إلا بالموافقة الكتابية من قبل المؤمن(") ولذلك لا يفسر سكوت المؤمن له على أنه قبول للتعديل ، وفي هذه الحالة يظل الضمان كما هو وفقا لقان للظروف القديمة ولن يكون أمام شركة التأمين إلا إنهاء العقد في الميعاد القانوني للإنهاء. ه- فيما يتعلق بالإشعارات المتعلقة بإنهاء العقد. إن عقد التأمين يهدف إلى تغطية المخاطر المستقبلية وبالتالي فإن إبرام العقد يستجيب للحاجة التي يشعر بها المؤمن له لأسباب معينة في ذلك الوقت ، لكن موقف المؤمن له قد لد يتغير مع مرور الوقت ، وباعتبار أن عقد التأمين من العقود الزمنية المستمرة فإنه يجب حماية

(1) (1) المادة ^ من مشروع وزارة الاقتصاد

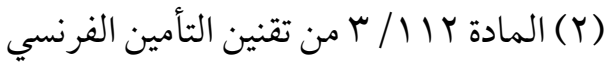


المؤمن له ومنعه من التورط في عقود طويلة الأمد لا تستجيب لحاجاته ، لذلك نجد مشروع وزارة الاقتصاد في المادة ع ب قد أعطى للمؤمن له وكذلك للمؤمن الحق في إنهاء العقد إذا زادت مدته عن خمس سنوات وذلك في نهاية كل خمس سنوات من مدة عقد التأمين بشرط إخطار الطرف الأخر قبل انتهاء مدة الخمس سنوات بستة شهور ، فيتم الإنهاء كحق من حقوق المؤمن بتوجيه خطاب موصى عليه بعلم الوصول يرسله إلى المؤمن له ، ويجب أن يصل هذا الكتاب إلى المؤمن له قبل انقضاء الخمس سنو ات بستة أشهر.

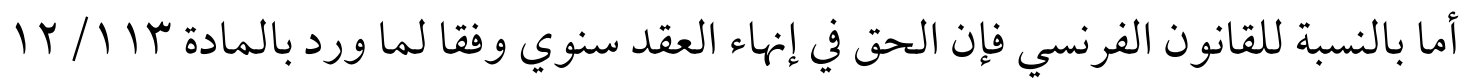
من تقنين التأمين حيث يسمح لطرفي عقد التأمين بالانسحاب من العقد وإنهائه وذلك بعد مضى مدة سنة من سريان العقد . فيحق للمؤمن أن يعلن المؤمن له بإنهاء العقد عن طريق إرسال خطاب موصى عليه أو بالبريد الالكتروني قبل شهرين على الأقل من تاريخ انتهاء العقد . وهذا الحكم لا ينطبق على عقود التأمين على الحياة سواء في القانون المصري أو لقانون

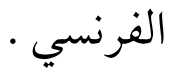
فيما يتعلق بالإشعارات المتعلقة بإنهاء العقد نتيجة تغير ظروف العقد فمنصوص عليه بالمادة س/ / / 1 من تقنين التأمين الفرنسي (1) التي تعطى شركة التأمين الحق في إنهاء عقد التأمين إذا حدث تغير في الأوضاع المرتبطة بالخطر المؤمن منه( كتغيير المسكن - تغيير الحالة الاجتماعية - تغيير المهنة - أو تغيير نظامها أو الوقف الدائم لأشطة العمل ) وكان لهذا التغيير التأثير على الخطر المضمون والمتمثل في أن العقد يغطى المخاطر المرتبطة بالوضع السابق والذى أصبح غير موجود في الوضع الجديد. 
في هذه الحالة يجب على شركة التأمين إذا اختارت الإنهاء أن يتم هذا الإنهاء بإرسال إشعار مسجل موصى عليه بعلم الوصول في خلال مدة ثلاثة شهور من تاريخ تغيير الظروف شترف المرتبطة بالمخاطر ، وعلى أن يسرى مفعول الإنهاء بعد شهر واحد من تاريخ تلقى المؤمن له

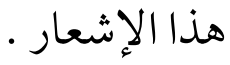

وفي هذه الحالة إذا كانت شركة التأمين قد قبضت قسط التأمين عن كامل السنة فيجب عليها أن تظهر حسن نيتها في رد جزء من القسط وذلك عن الفترة المتبقية بالعقد التي لم

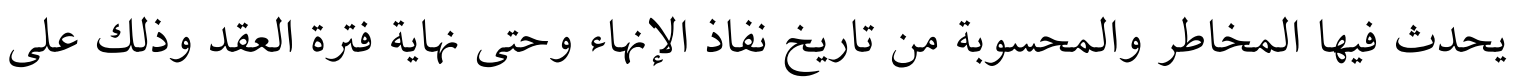
اعتبار أن قسط التأمين يتم سداده مقدما وهو قابل للتجزئة (1).

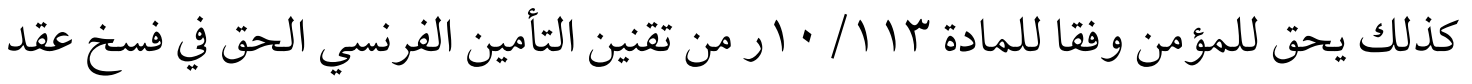

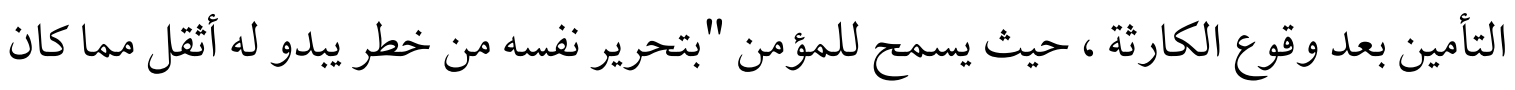

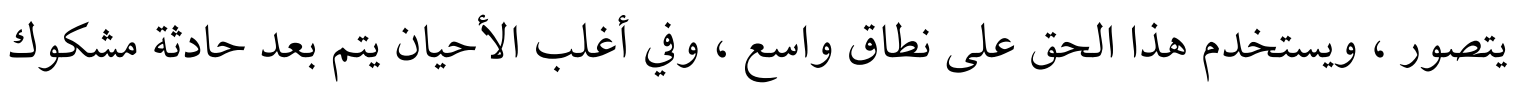

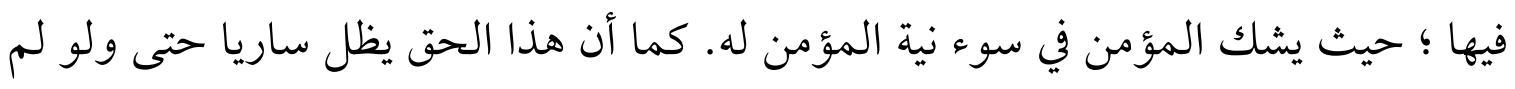
يكن للمؤمن له أي دخل في وقوع الحادث ويتم ذلك عن طريق إخطار المؤمن للمؤمن له بخطاب مسجل بعلم بعلم الوصول أو بالبريد الالكتروني المسجل ، ويسرى الإنهاء بعد فوات شهر من تاريخ الإخطار. ويجب على المؤمن أن في هذه الحالة أن يرد جزءا من القسط المدفوع مقدما عن الفترة المتبقية بالعقد والني تبدأ من تاريخ نفاذ الإنهاء. ويجب على المؤمن أن يستخدم هذا الحق في الإنهاء في خلال شهر من تاريخ المطالبة ؛ لذلك فإنه لا يكون له الحق في إنهاء العقد اعتمادا على فكرة الحادث وذلك في حال قبوله 
استلام قسط التأمين بعد شهر من علمه بالمطالبة وذلك عن فترة التأمين التي تبدأ بعد الحادث.

كذلك يحق للمؤمن فسخ عقد التأمين في حال انتقال ملكية الشيء المؤمن عليه إلى شخص آخر (1)"ويقع ذلك عادة بكتاب موصى عليه بعلم الوصول يرسله المؤمن إلى المؤمن له الجديد وذلك إذا كان قد أخطر بانتقال الملكية ، فإذا لم يكن قد أخطر بذلك فيجوز للمؤمن إرساله إلى المؤمن له الأصلي باعتباره نائبا عن المؤمن له الجديد((r)ويجوز للمؤمن أن يطلب الفسخ في هذه الحالة من وقت أن يعلم بنقل الملكية . في القانون الفرنسي يحق لشركة التأمين إنهاء العقد في غضون ثلاثة أشهر من اليوم الذي يكون فيه المستفيد النهائي من الأشياء المؤمنة طلب نقل الملكية إلى اسمه(م). كذلك في حال إفلاس المؤمن له يحق للمؤمن فسخ عقد التأمين() ويقع ذلك في القانون الفرنسي بكتاب موصى عليه بعلم الوصول يرسله المؤمن إلى السنديك ويجب أن يتم الفسخ في خلال ثلاثة شهور من تاريخ صدور الحكم بالإفلاس أو التصفية ، ويجب على المؤمن إثباتا لحسن نيته أن يرد الجزء المدفوع من القسط المقابل للمدة الباقية من السنة الجارية محسوبة منذ وقوع الفسخ ويكون سبب الرد عدم تحمل المؤمن أية مخاطر عن هذه الفترة ، ويكون الرد إلى جماعة الدائنين.

7- مضمون التزام المؤمن بحسن النية في عقود التأمين على الحياة. أما بخصوص عقود التأمين على الحياة فإن شركة التأمين ملتزمة بإبلاغ المؤمن له

(1) المادة Yr/ ا من مشروع وزارة الاقتصاد يقابلها المدة V • ا من المشروع التمهيدي للقانون المدني

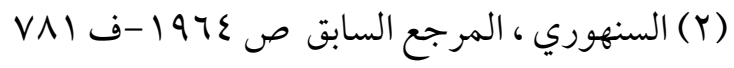

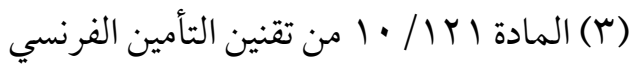

$$
\begin{aligned}
& \text { (ع) المادة كس// ا من مشروع وزارة الاقتصاد }
\end{aligned}
$$


بمعلومات معينة أثناء سريان عقد التأمين :

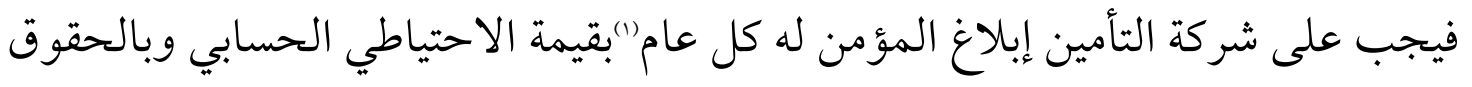

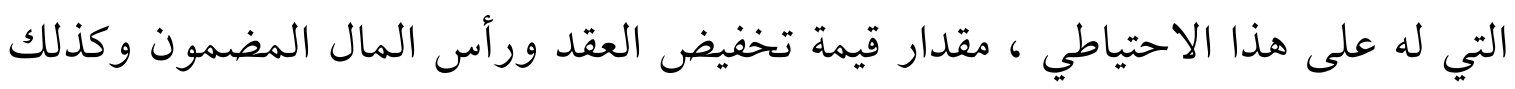

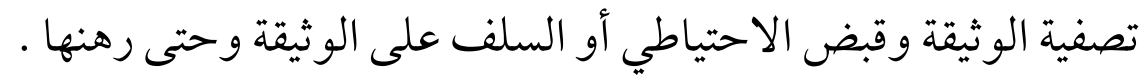

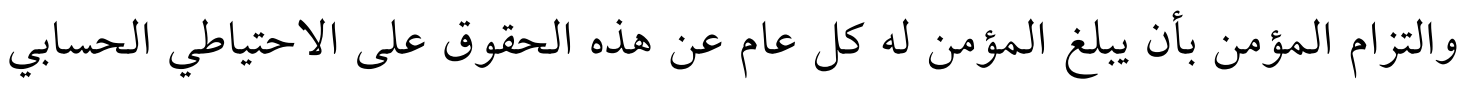

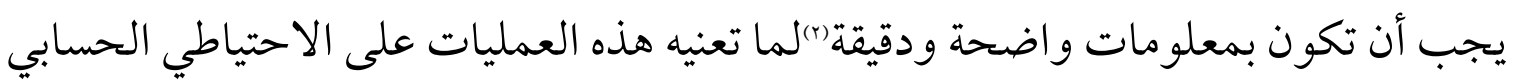
وما هي عو اقبها القانونية والتعاقدية. كما يجب على شركة التأمين الاستجابة بحسن نية لمطالب المؤمن له المشروعة والمقدمة لها خلال سريان العقد ، وفي هذه الحالة تتجاوز حسن نية شركة التأمين فكرة المعلومات المقدمة له عن الاحتياطي الحسابي والحقوق التي ترد عليه ليصبح حسن النية عملي بالاستجابة بشكل إيجابي لطلبات المؤمن له المشروعة أثناء سريان عقد التأمين على الى لحسي

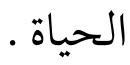

نتيجة لذلك يحق للمؤمن له في القانون المصري"(أن يستبدل بالوثيقة الأصلية وثيقة

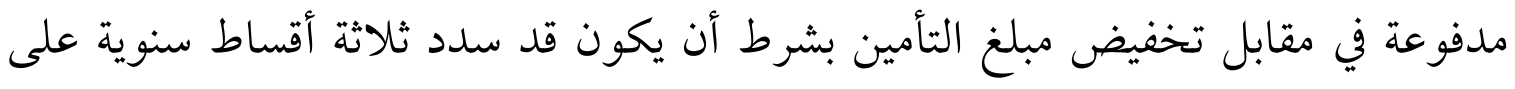

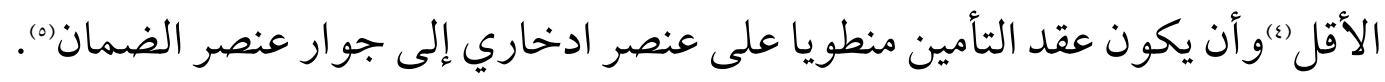

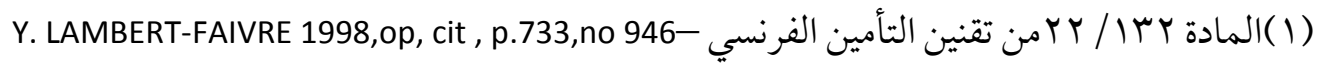

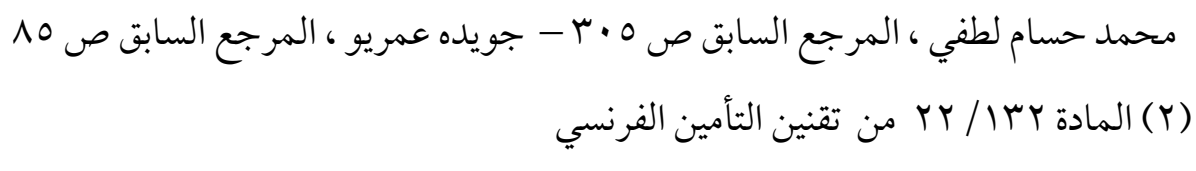

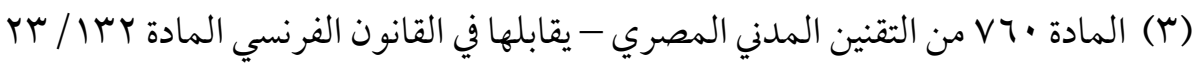

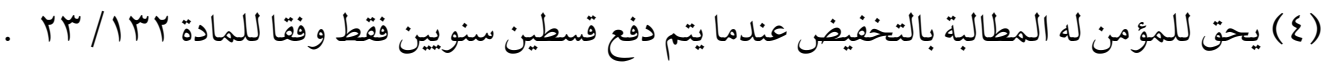
Y . Lambert-Faivre,1998, op, cit , p.733, no 947

$$
\text { r (0) محمد حسام لطفي ، المرجع السابق ص r.r }
$$


ولا يعتبر التخفيض عقد تأمين جديد يحل محل عقد التأمين الأصلي ، بل إن العقد الأصلي باق كما هو بنفس شروطه وبنفس مدته ولم يتغير فيه سوى شيء واحد هو مبلغ التأمين الذى خفض ولن يستحق إلا عند انتهاء مدة الوثيقة الأصلية'(1). ولا يمكن لشركة التأمين رفض طلب التخفيض عند طلبه من المؤمن له حتى ولو اتفق طرفي التأمين على غير ذلك ؛ فالتحفيض يتم بحكم القانون سو اء طلبه المؤمن له أو لم يطلبه إذا تو افرت شروطه ؛ وذلك لأن الأحكام الواردة بشأن التخفيض أحكاما آمرة ليس للأطراف الخروج عليها إلا بالقدر الذى يحقق مصلحة المؤمن له دون سواه (r). إضافة إلى ذلك يحق للمؤمن له إذا توافرت الشروط سالفة الذكر للتخفيض أن يطلب تصفية عقد التأمين ، فيترتب على طلب التصفية إنهاء عقد التأمين من تاريخ الطلب(r) حصول

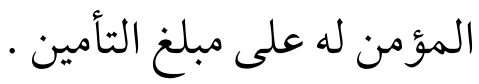
وتشترط وثائق التأمين عادة أن يكون للمؤمن مهلة ثلاثة شهور من يوم مطالبة المؤمن له بتصفية عقد التأمين وذلك لدفع قيمة التصفية() ولا تتم التصفية بحكم القانون بل يجب أن يطلبها المؤمن له ، فإذا طلبها المؤمن له فيجب على المؤمن الاستجابة لطلبه إذا توافرت شروطها (0)، وهذا معناه تحويل دين المؤمن له العالق بذمة المؤمن من دين مؤجل إلى دين

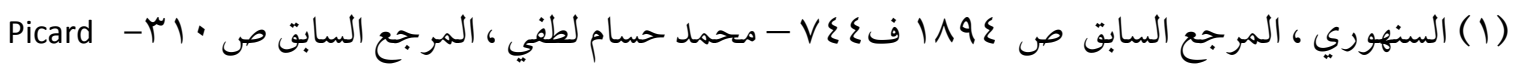
et André Besson, op, cit , p.642,no 444

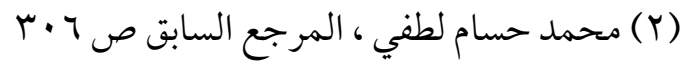

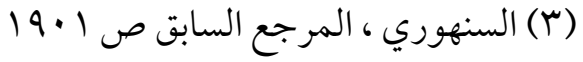

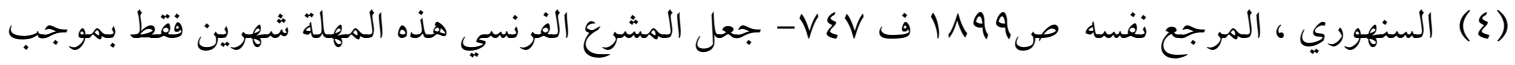

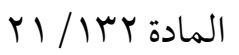

(0) في القانون الفرنسي لا إلزام على المؤمن بالاستجابة لطلب التصفية المستوفي شروطه إذا كان هناك ظرف

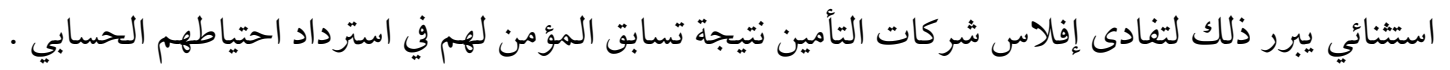

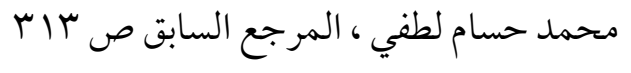


حال واجب الأداء دون إبطاء(1)، ويلتزم المؤمن بدفع الفوائد القانونية في حال تأخره في

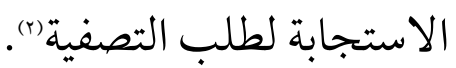

كذلك يحق للمؤمن له أن يلجأ إلى السلف على الوثيقة بغرض الحصول على حاجته من النقود دون أن ينهي عقد التأمين الذى يربطه بالمؤمن (ت)وذلك إذا تو افرت الشروط سالفة الذكر فئر بالنسبة للتخفيض والتصفية ـ وتمثل هذه السلفة جزء من الاحتياطي الحسابي للمؤمن له وبحيث لا يتجاوز حدها الأقصى قيمة التصفية . ولا إلزام على المؤمن في الاستجابة لطلب المؤمن له بتعجيل سلفة على الوثيقة حيث يعد النعجيل على حساب الوثيقة اختياري(") إلا أن العمل كشف عن عدم تردد المؤمن في الاستجابة لطلب السلفة على أساس أن قيمة السلفة مرهونة بقيمة التصفية وأنه لا يتحمل أية مخاطر عند قبوله لهاه(مل إنه على العكس يتقاضى فائدة تعوضه عما فاته من استغلال النقود التي يعطيها للمؤمن له ، وإذا تأخر المؤمن له عن دفع أقساط الفو ائد المستحقة عن السلفة بهنة

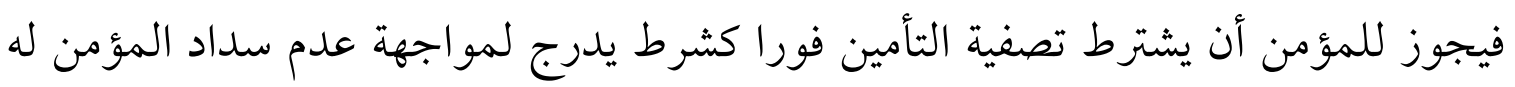
للفو ائد المستحقة عليه، (1). بالإضافة إلى حسن نية المؤمن بخصوص المعلومات المتعلقة بالاحتياطي الحسابي والحقوق التي تجب للمؤمن له على هذا الحساب فإن حسن نية المؤمن تتوافر أيضا

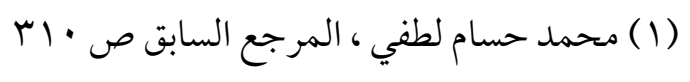

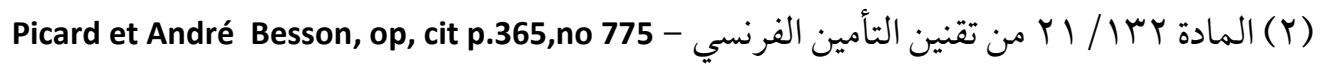

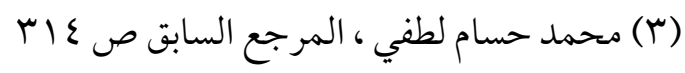

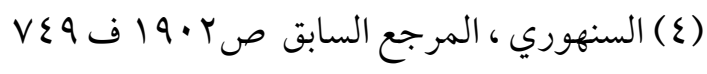

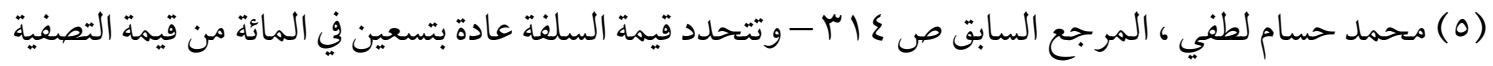
(6)Picard et André Besson,op,cit,p.776,no397 - Y. Lambert-Faivre,1998 op,cit, p.733,no 949 
بمو افقته على عدول المؤمن له وتراجعه عن التعاقد".

ففي القانون الفرنسي يحق للمؤمن له الذى قام بالتوقيع على وثيقة التأمين على الحياة العدول عن التعاقد بإرسال خطاب مسجل بعلم الوصول أو بالبريد الالكتروني المسجل وذلك في خلال ثلاثين يو ما من تاريخ إعلامه أن العقد قد أبرم (r). فإذا مرت مدة التفكير وهي الثلاثون يوما بعد انعقاد العقد فلا يحق للمؤمن له العدول عن العقد بعد ذلك(r) أما إذا استخدم المؤمن له حقه في العدول عن التعاقد فيجب على شركة التأمين إعادة القسط المدفوع إلى المؤمن له وذلك بعد خصم تكلفة العقد()وذلك في خلال مدة أقصاها ثلاثون يوما من تاريخ استلام اخطار العدول عن التعاقد ، فإذا تأخر المؤمن عن سداد المبالغ المستحقة للمؤمن له نتج عن هذه المبالغ غير المعادة فوائد قانونية تلقائية حتى

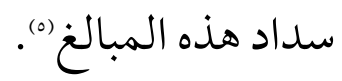

\section{ثانيا: حسن نية المؤمن في الالتزام بالتغطية قبل وقوع الخطر .}

يعد الخطر هو السبب الرئيسي الذى يضطر المؤمن له للتعاقد مع شركة التأمين كما أنه

$$
\begin{aligned}
& \text { (1) لا يعرف القانون المصري فكرة العدول عن عقد التأمين كحق للمؤمن له بعد التعاقد مباشرة . }
\end{aligned}
$$

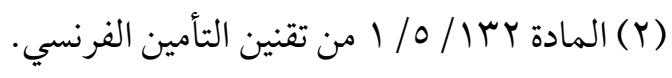

(3) Cass.2 Ch CiV. 25 Fevrier 2010, , n 09-11.352, D. jurisprudence. 2010, n 12, p 708

(ع ) فالمؤمن له بصفته مستهلك لا يلتزم بدفع جزاءات لاستعماله حقه في العدول ، إنما يتحمل مصاريف العقد فقط ، وتكون تلك المصروفات بسيطة لا تؤدى إلى عزوفه عن استعمال حقه في الرجوع ، وفي ذلك تحقيق

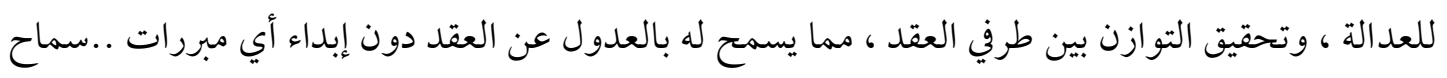

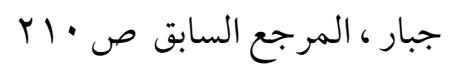

(0) المادة r// / 1/ من تقنين التأمين الفرنسي - في تأمين الأضرار يحق للمؤمن له التراجع عن التعاقد وفقا

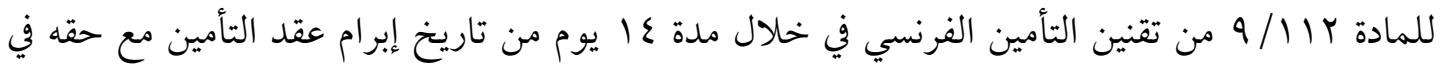

$$
\text { استرداد قسط التأمين بعد خصم مصروفات العقد. }
$$


يشكل المحور الذى تتجمع حوله العناصر المختلفة لعقد التأمين ·

بالتالي فإن عقد التأمين هو الحل الأمثل لهذا الخطر الذى يشكل حدثا غير مؤكد الوقوع ، ويتخذ هذا الحل شكل استجابتين مميزتين تقدمهما شركة التأمين : فمن ناحية سوف تلتزم شركة التأمين بضمان تغطية المخاطر أثناء مدة عقد التأمين ، ومن ناحية ثانية فإن شركة التأمين سوف تلتزم بالتسوية"(1) دفع التعويض في حال اكتمال حدوث المخاطر (r). فعقد التأمين يعتبر من عقود المعاوضات ؛ لأن كل طرف فيه يأخذ مقابلا لما يعطى ، فالمؤمن له يدفع القسط في مقابل تحمل المؤمن تبعة الخطر طوال مدة العقد سواء تحقق أو لم يتحقق (r) تعهده بدفع مبلغ التأمين في حال تحقق الخطر (s). فعقد التأمين عقد تام نافذ ينتج كافة آثاره ويرتب آثاره كاملة على الطرفين منذ إبر امه (0) كل

(1) يعتبر الفقيه Mouly هو أول من قدم هذا التمييز بين الالتزام بالتغطية والالتزام بالتسوية في رسالته عن أسباب

$$
\text { انتهاء عقد الكفالة . }
$$

C. Mouly, Les causes d'extinction du cautionnement, Université de Montpellier I, 1977

$$
\text { وقد لاقت وجهة نظره تأييدا كبيرا في الفقه }
$$

(2) Eloïse Haddad, Les notions de contrat d'assurance, THÈSE, UNIVERSITE PARIS I PANTHÉOn SORBONNE, Ecole de droit la Sorbonne,2017,p.154 - L. Mayaux, Encyclopédie Dalloz, Droit civil, Ass. terr., §141

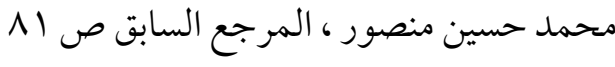

$$
\begin{aligned}
& \text { أحمد شرف الدين ، المرجع السابق ، ص ل V ف } 10
\end{aligned}
$$

تعد تغطية المخاطر هي الالتزام الأساسي لعقد التأمين ، مطلوب من المؤمن تغطية الالتزامات الناشئة من يوم إبرام العقد وطوال المدة المحددة بالعقد ، وتضمن الأداء المتفق عليه في حال وجود مطالبة ، وهذا الأداء هو

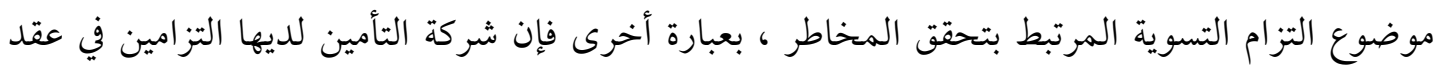

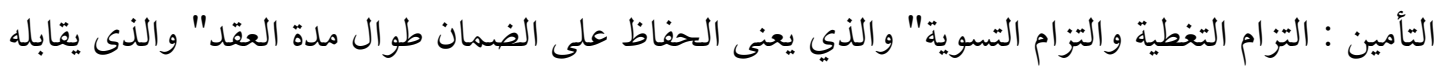

L. Mayaux, OP.CIT., §141

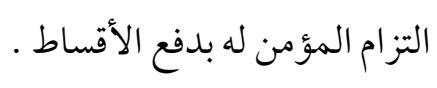

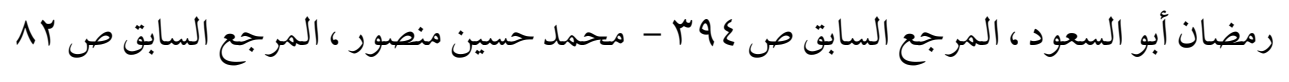


ما هناك أن تقدير التزام المؤمن متوقف على وقوع الكارثة ، فالتزام المؤمن التزام حال ولكن مقداره يتوقف على درجة خطورة الحادث المؤمن عليه فقد لا يدفع شيئا إذا لم يقع الحادث وقد يدفع قليلا إذا كانت نتائج الكارثة قليلة ، وقد يدفع كثير ا إذا بلغت الأضرار حدا كبيرا . فيجب على المؤمن أن يكون حسن النية في أدائه التزامه بالتغطية قبل حدوث المخاطر المؤمن منها ، وهذا الالتزام التزام موجود بمجرد انعقاد عقد التأمين حيث يتعهد المؤمن بضمان المؤمن له ضد آثار الخطر المتفق عليه في العقد ويلتزم بتنفيذ هذا التعهد بالوسائل المناسبة في حال تحقق الخطر المذكور (1). فالتزام المؤمن بالتغطية التزام نشعر بوجوده ولا نستطيع أن نبلوره في أمر محسوس فهو مثل الامتناع عن عمل ليس له وجود مادى ملموس ، إلا أنه يترتب عليه آثار قانونية في غاية

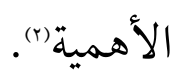

فالمؤمن يضع تحت أمر المؤمن له جميع إمكانياته وكل استعداداته من أجل تغطية الخطر

$$
\text { المؤمن منه }
$$

فالتزام المؤمن بتغطية الخطر موجود طوال مدة العقد(s) لا يقلل من وجوده أن الخطر قد لا يتحقق (م)لذا سو اء لم يتحقق الخطر المؤمن منه وسو اء لن يتحقق أبدا هذا الخطر ، فالمؤمن مستعد لإتمام ما تعهد به ، وبالتأكيد فإن استعدادات المؤمن على هذا النحو سوف تكبد

(1) د. عابد فايد ، تصور حديث لالتزام المؤمن في عقد التأمين ، مجلة الدراسات القضائية معهد التدريب

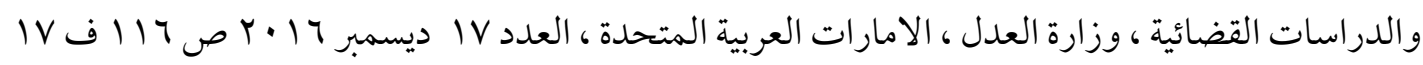

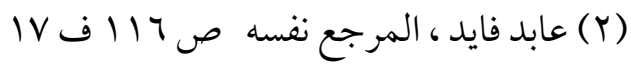

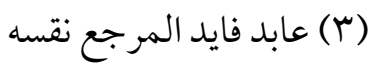

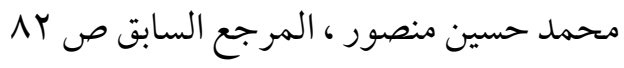

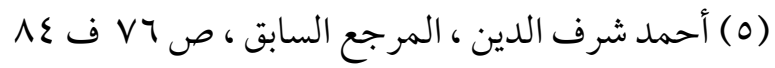




\section{مشروع التأمين نفقات ومصاريف طائلة").}

إن عقد التأمين باعتباره عقدا تبادليا ينشئ التزامات متقابلة على عاتق كل من المؤمن والمؤمن له ، فإذا كان المؤمن له يتعهد بتحمل تبعة الخطر المؤمن ضده وأخذها على عاتقه مقابل تعهد المؤمن له بدفع الأقساط بحيث يعتبر التزام كل طرف سببا لالتزام الآخر (r). فالالتزام بالتغطية يمثل على هذا النحو سبب التزام المؤمن له بدفع الأقساط (r) يفترض أن كل جزء من القسط محل التزام المؤمن له يقابل جزءا من الضمان محل التزام المؤمن ويترتب على ذلك إذا توقف المؤمن له عن دفع القسط فإن المؤمن لا يمنح ضمانه مجانا أو بدون مقابل ، بل سيضع حدا للالتزام بتغطية المخاطر (2)لهذا منحه القانون الحق في أن يوقف التزامه بالضمان ، وإذا أوقف المؤمن الضمان كجزاء لإخلال المؤمن له بدفع القسط فإنه يظل دائنا بالقسط خلال فترة الوقف ، وهذا ليس تطبيقا لمنطق التبادلية بين الالتزامات و إنما على سبيل العقوبة للمؤمن له المهمل في أداء الالتزام الملقى عليه ، فمنطق التبادلية بين الالتزامات يستوجب عندما يوقف أحد الالتزامات أن يتم وقف الالتزام المقابل لهـ.

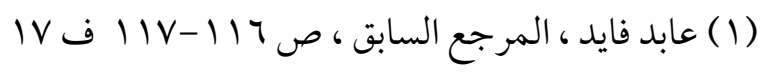

وقد لاقى مفهوم الالتزام بالتغطية انتقادات كثيرة حيث يعتبره بعض الفقه خالي من أي شيء حيث إن الضمان غير

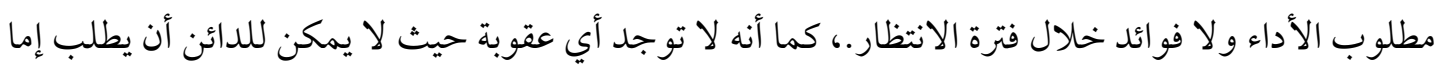
تنفيذ الالتزام بالتغطية جبريا أو الحصول على تعويضات عن عدم الأداء. فإذا عدنا إلى مفهوم الالتزام بمعناه

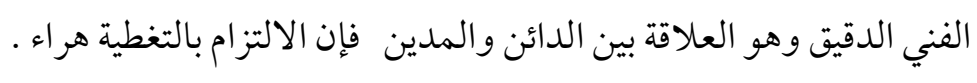

P. Ancel, " Force obligatoire et contenu obligationnel du contrat », RTD civ., 1999 cette analyse est d'ailleurs reprise dans des thèses récentes V. Mazeaud L'obligation de couverture cit. et N. Bargue, Essai sur la notion de garantie, Th. dactyl. Université Paris I, 2008, §161 et s s

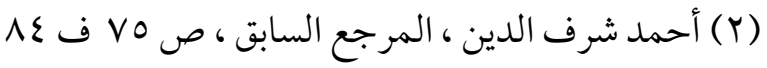

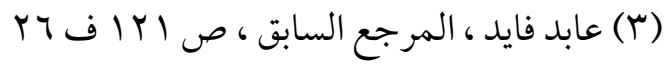

(4) L. Mayaux, OP.CIT., §141

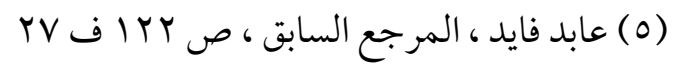


وإذا كان الالتزام بالتسوية محددا بالضرورة من حيث الكم ؛ حيث إنه محصور في حدود مبلغ التأمين المتفق عليه ، كذلك فإن الالتزام بالتغطية مقيد بالتفاصيل التي تقدمها شركة التأمين والتي تتعلق بتحديد المخاطر المشمولة . فتحديد المخاطر مرتبط بنوعين من الشروط وهما : شروط الضمان ، واستثاءات الضمان و التي تساهم بطريقة مختلفة في التحديد الدقيق للمخاطر المؤمن عليها. تعتبر شروط الضمان متطلبات عامة ودقيقة يخضع لها الضمان ، وفي الغالب تكون أحداثا خارجة عن موضوع العقد ، ويعتمد عليها في وجود التزام تغطية المخاطر التي تتحملها شركة التأمين"(1) تساهم هذه الشروط بشكل كبير في تحديد مدى الضمان ، مع تقليل احتمالية · المخاطر

فهذه الشروط تهدف بوضوح إلى تشجيع المؤمن له على توخى الحذر والحيطة ومنها على سبيل المثال في تأمين المسئولية من حوادث السيارات اشتراط الحصول على رخصة قيادة محددة .

كما أن البعض من هذه الشروط تذهب إلى أبعد من ذلك عن طريق وضع ترسانة حقيقية لمنع المخاطر أو الحد الأدنى من تدابير الحماية التي يجب تنفيذها قبل سريان الضمان على أن تكون هذه التدابير شرطا مسبقا للضمان الذى يؤجل إلى أن يتم الانتهاء من هذه الإجراءات ومن قبيل هذه التدابير تدابير الحماية والأمن لإبرام عقد التأمين ضد مخاطر السرقة ، لا سيما فيما يتعلق بالمتاجر التي تقدم منتجات باهظة الثمن كالمجوهرات وما إلى ذلك ، حيث يكون هناك حاجة إلى تركيب جهاز كامل ومتقن لحماية الفتحات الرئيسية لهذه المتاجر ، وهي الأبواب والنوافذ ، وغالبا ما يتم الجمع بين الأليات اليدوية : كالأقفال

(1) Bigot, Beauchard, Heuzé, Kullmann, Mayaux, Nicolas, Traité de droit des assurances, T.3 L.G.D.J , 2014, $n^{\circ} 1712$ 
والمصاريع الخشبية ، ونوافذ واقية من السرقة ، إضافة إلى أجهزة آلية معدنية صلبة ، مع

$$
\text { تحكم كهربائي وأجهزة إنذار ومراقبة . }
$$

تمثل هذه الإجراءات الوقائية شرطا ضروريا لتولى مسئولية شركة التأمين ، حيث يطلب

$$
\text { من المؤمن له الالتزام بهذه الإجراءات بدقة متناهية . }
$$

فمفهوم الضمان الذى يستدعى الالتزام بتغطية المخاطر ، والالتزام بالتسوية تعارض

استبعاد الضمانات التي تشير إلى ظروف خاصة وحالات معينة من إدراك الخطر والتي تكون

مستبعدة ولا تدخل في تغطية شركة التأمين.

من حيث الشكل القانوني فإن شروط الضمان لا تخضع لأي إجراء شكلي معين وذلك

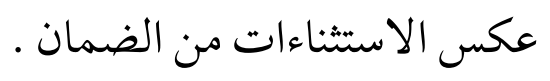

بشكل أكثر تحديدا لا يجب أن تكون شروط الضمان رسمية ومحددة أو حتى يتم الإشارة

إليها بأحرف واضحة للغاية ، بل يكفي فقط أن تكون واضحة ودقيقة ـ أما الاستثاءات من الضمان فهي تخضع للطبيعة الرسمية ويتطلب أن تكون مكتوبة بدقة وبأحرف ظاهرة في وثيقة

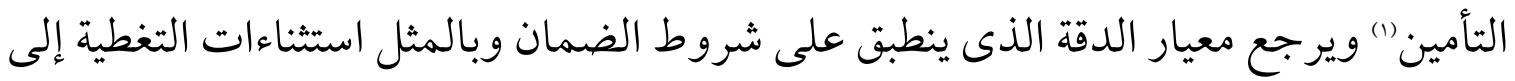
حظر لجوء شركة لتأمين إلى مفاهيم غامضة أو غير محددة .

بخصوص شروط الضمان وبخاصة بعض المتطلبات التنظيمية المتعلقة بتدابير الحماية فإنه يكفي الإشارة إليها فقط دون مزيد من التفاصيل حول الطبيعة الدقيقة لهذه المعايير")، أما استبعاد الضمان فإنه يجب أن يكون مصحوبا بمعلومات وتفاصيل يجب أخذها في الاعتبار

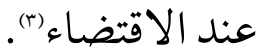

(2) Cass. 1ère civ., 8 octobre 1974, $n^{\circ} 73-12497$

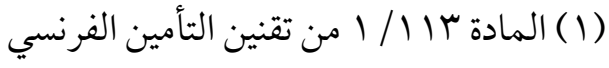

(3) Cass. 3ème civ., 24 mars 2015, n 13-25737 
وهذه الشروط وهذه الاستثناءات هي التي تسمح للمؤمن له أن يعرف بالضبط مدى الخطر المؤمن عليه (1)

\section{ثالثا : حسن نية المؤمن في الالتزام بالتسوية ( أداء التعويض)} أثناء تنفيذ عقد التأمين يمكن أن يقع الحادث المؤمن منه ، وفي هذه الحالة ينتقل حسن نية المؤمن من التزامه بالتغطية إلى التزامه بالتسوية أو بدفع التعويض المستحق ، وفي هذه الحالة يمكن القول بأنه تم استبدال التزام المؤمن بالمعلومات والتزامه بالاستعداد بالتزامه الأساسي بأدائه تجاه المؤمن له أو المستفيد من عقد التأمين المبرمج". أ :حسن النية في إجراءات التعويض.

يجب على كل شركة تأمين احترام كل المتطلبات القانونية المتعلقة بإجراء التعويض على

$$
\text { أن يكون سريعا وعادلا في هذا الإجراء. }
$$

فيجب على شركة التأمين وهي بصدد ممارسة حقها في مراجعة الحسابات والتحقق من حقيقة المخاطر التي حدثت والتي تنشأ عنها مسئولتها في التعويض ، وكذلك التحقق من وجود احتيال من عدمه ، و أن تحترم المو اعيد النهائية للتعويضات والمحددة بعقد التأمين". فإعلان المؤمن له عن حدوث المخاطر ومطالبته بالتعويض المنصوص عليه بعقد التأمين ينشأ عنه عملية مراجعة دقيقة للمخاطر التي حدثت والتي قد تؤدى إلى دفع تعويض للمستفيد خلال الوقت المحدد إذا كان من المحتمل أن تنطوى هذه المخاطر على مسئولية

(1) Cass. 2ème civ., 16 décembre 2004, nº3 -18232.

(Y) بعض الفقه يرى أن التزام المؤمن الأساسي هو دفع التعويض المستحق فقط ولذا فإنه يرى أن حسن نية المؤمن في هذه المرحلة لم يعد يهدف إلى تنظيم التزامه بالمعلومات ، بل أداء الخدمة وهى دفع التعويض

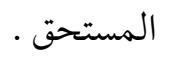

PATRICE FIL, op ,cit , p.85

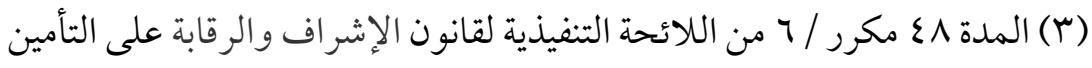




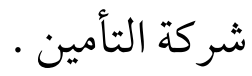

وإذا كانت هذه المراجعة لحماية شركات التأمين العاملة في قطاع التأمين إلا أنه لا ينبغي تنفيذ هذه المراجعة عن طريق المساس بحقوق المستفيد ، وحرصا على ذلك ولكى يتم

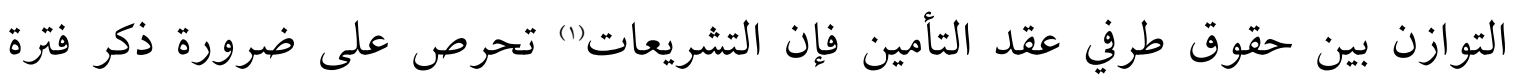
التعويض بوثيقة التأمين(") ، وهذه الفترة بمجرد ذكرها تصبح ملزمة لشركات التأمين ويتم

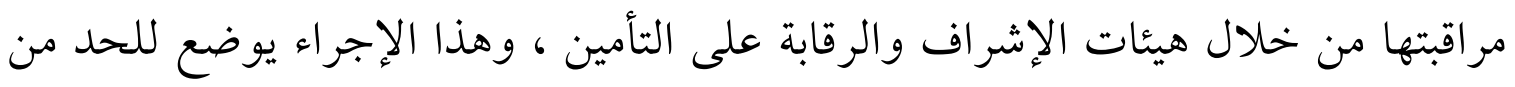

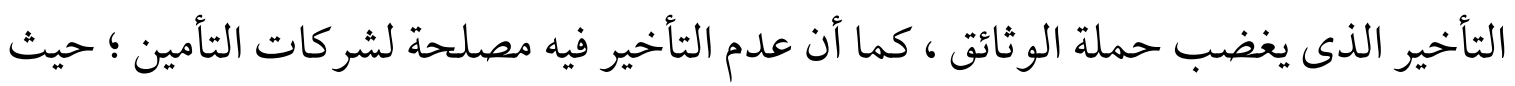

(1) المادة 1 ع مكرر / T من اللائحة التنفيذية لقانون الإشر اف والرقابة على التأمين

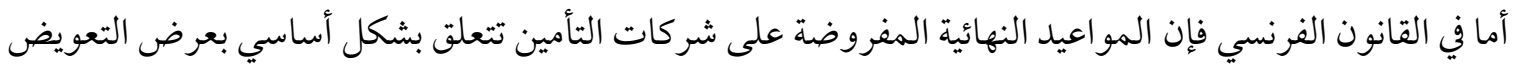

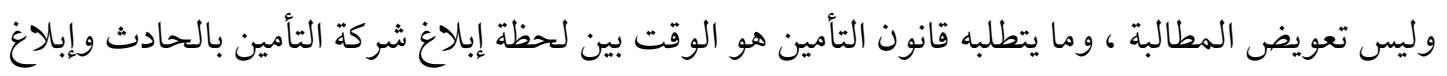

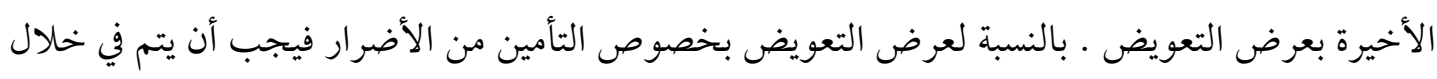

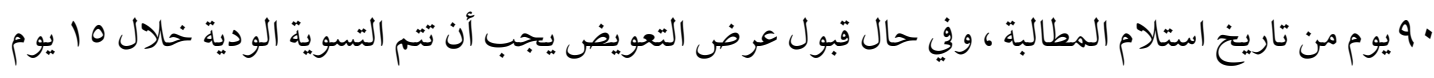

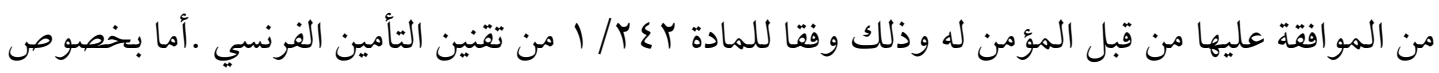

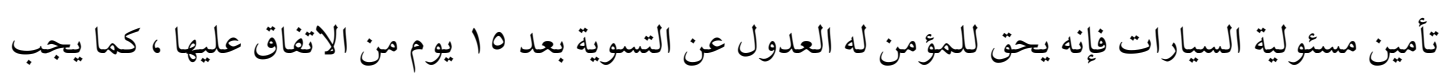

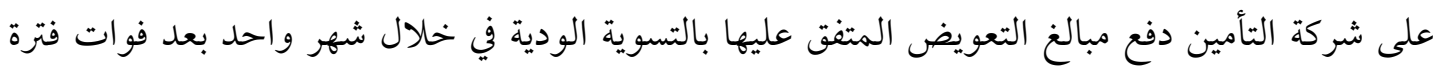

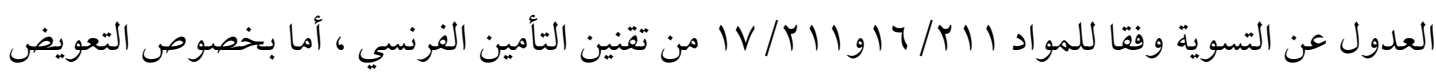
عن الكوارث الطبيعية فيجب تخصيص التعويض الناتج عن هذا الضمان للمؤمن عليه في غضون ثلاثة أشهر

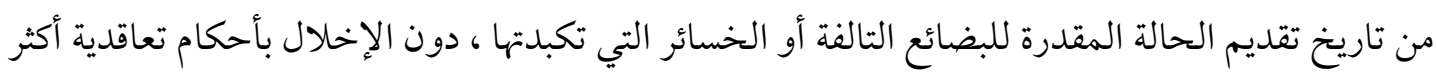

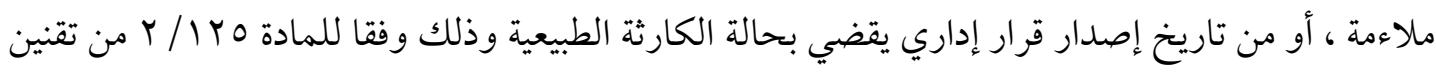

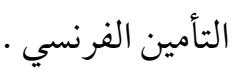
(Y) وقد جرى العرف التأميني في مصر على إلزام المؤمن بسداد مبلغ التأمين في موعد غايته ثلاثين يوما من تاريخ

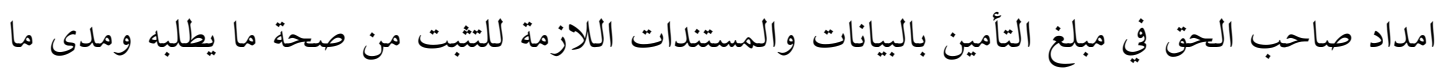

$$
\text { يتمسك به من حقوق . (محمد حسام لطفي ، المرجع السابق ص ع ع r ) . }
$$


يعزز صورة العلامة التجارية لها ، كما أنها تقى نفسها من التعرض للعقوبات والمتمثلة في الفائدة المحددة بأحكام القانون كتعويض عن الضرر الواقع على المؤمن له من جراء التأخير في دفع التعويض ، وهذا الضرر مفترض لا يلتزم المؤمن له بإثبات وقوعه من جراء التأخير (1).كما يجوز للمؤمن له المطالبة بالتعويض عن خسائره عن التأخير في حال إثبات سوء

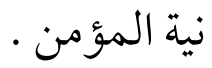

عمليا تتلقى شركة التأمين مطالبة المؤمن له أو أي شخص له مصلحة في استلام التعويض، في هذه الحالة تقوم الشركة بعمل ملف للكارثة وتضع فيه التصور المبدئي والمؤقت للكارثة ، وفي حال حصول الشركة على التصور الكامل والنهائي للكارثة وتأكدها من عدم وجود أي شكوك حول مطالبة المؤمن له فيجب على شركة التأمين تقديم التعويض وفقا للشروط التعاقدية التي حددتها مع المؤمن له (r). أما في حال عدم اكتمال ملف الكارثة فيجب على شركة التأمين إظهار الحسن نيتها أن تقوم بإبلاغ المدين بحاجتها إلى بعض المستندات التي يجب عليه أن يقوم بتوفيرها(). . قد ينشأ موقف أخر وهو شكوك شركة التأمين التي تتعلق بالوقائع التي أعلن عنها المؤمن له في هذه الحالة يجب على شركة التأمين أن تقوم باتخاذ التدابير والإجراءات التي تهدف إلى إظهار الحقيقة() ؛ فتتحقق شركة التأمين من خلال قسم المطالبات من وقوع الخطر وحجم الضرر الذى لحق بالمؤمن له وذلك لتحديد مسئوليتها وتعيين مبلغ التأمين ·

(2) Khalifi Taghzouti, et d'autres, op , cit, p.20

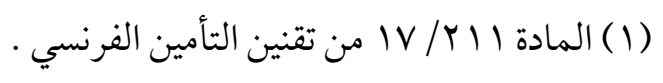

$$
\text { (Y) المادة \乏 مكرر / T من اللائحة التنفيذية لقانون الإشر اف والرقابة على التأمين }
$$
(ع) وهذا محدد بنص المادة ^ع مكرر / T من اللائحة التنفيذية لقانون الإشراف والرقابة على التأمين وهذه

$$
\text { الإجراءات هي المعاينة والاستعانة بالخبراء }
$$


في هذه المرحلة قد يتم مساعدة شركة التأمين عن طريق خبير أو أكثر من أجل أن تؤخذ تقاريرهم في الاعتبار ، فإذا امتثلت شركة التأمين لهذه التقارير قامت بسداد التعويض للمؤمن له أو للمستفيد ، أما إذا لم تمثثل الشركة لهذه التقارير- وهذا وضع نادر لأنه في كثير من الأحيان يتم اتباع هذه التقارير - وذلك لأن تقارير الخبراء غير ملزمة لشركات التأمين مثلها في مثل التزام القضاة تجاه هذه التقارير فيحق للمؤمن له أو المستفيد اللجوء إلى الإجراءات المنصوص عليها في القانون للحصول على التعويض"ن.

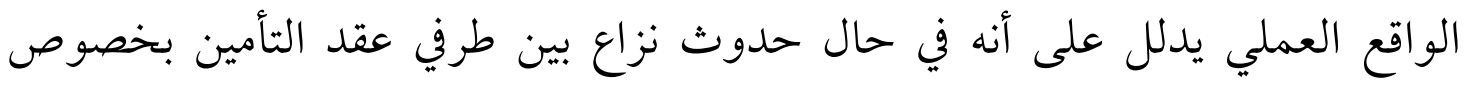

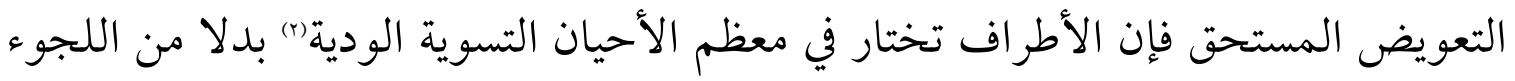
إلى القضاء ويبرر ذلك بأنه في صالح جميع الأطراف بسبب الطول المفرط للإجراءات القضائية ونفتتها العالية(ه) تقلب قرارات القضاة فيما يتعلق بمبلغ التعويض الممنوح ، وبالتالي يفضلون التوصل إلى اتفاق سيء بدلا من دعوى قضائية جيدة (s). ب : احترام المواعيد المقررة لدفع التعويضات.

يجب على شركة التأمين أن تثبت حسن نيتها من خلال دفع التعويض في خلال فترة

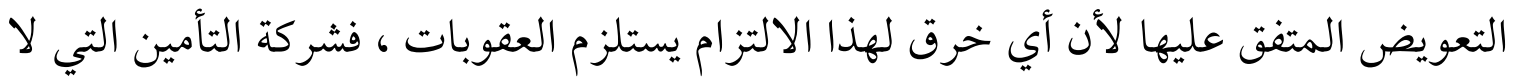

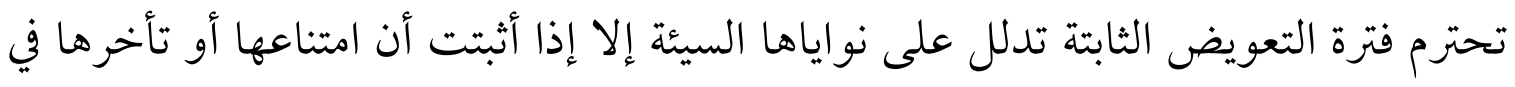

(1) وهذه الإجراءات منصوص عليها بالمادة 1) مكرر / T من اللائحة الثنفيذية لقانون الإشراف والرقابة على Khalifi Taghzouti, et d'autres, op , cit, p.20 التأمين. (2)Picard et André Besson, op, cit , p.231,no 141-Y. Lambert-Faivre 1998, op, cit , p.347,no 512. (بحمد نبهى ، الطرق البديلة لتسوية النزاعات التجارية ، رسالة ماجستير ، جامعة الجزائر ا ، كلية الحقوق ،

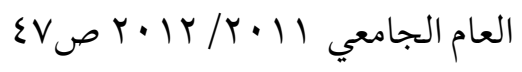

(4) Henriette E. Kameni,op,cit ,p.70 


$$
\text { سداد التعويض له ما يبرره"(1) - مأ. }
$$

فأي تأخير غير مبرر في سداد التعويض سيؤدى إلى دفع شركة التأمين للتعويض المستحق إضافة إلى الفوائد المستحقة عن هذا التعويض من تاريخ المطالبة القضائية()ما لم يتفق على غير ذلك كأن يتفق أطراف عقد التأمين على حسابها من تاريخ وقوع الكارثة(r). كما يجوز للمؤمن له أن يطالب بتعويض إضافي إذا ماطل المؤمن في سداد مبلغ التأمين بعد ثبوت حقه وذلك إذا أثبت وجود خطأ فاحش أو رفض تعسفي يعكس سوء نية المؤمن في تأخير السداد(s)، كما أن استمراره في عدم الدفع قد يعرضه للغرامة القضائية. ج : الدفع للمستفيد من التعويض. يدفع التعويض ليد الشخص الذى يحق له الحصول عليه ، فيكون الدفع للمؤمن له إذا كان هو المستفيد من العقد (0)، وإذا كان المستفيد شخصا آخر غير المؤمن له ، كأن يكون عضو افي عائلة المؤمن له مثل الوريث أو المستفيد في حالة الوفاة فيكون الدفع لهذا المستفيد ، كما أنه قد يكون المستفيد شخصا ثالثا في عقد التأمين غير محدد أو معين شخصيته كما هو الحال في تأمين المسئولية، كالتأمين الإجباري على المسئولية عن قيادة السيارات ، في هذه الحالة يكون الدفع لهذا المضرور ، كما أن الدائن الممتاز أو المرتهن يحص كذلك على وضع المستفيد

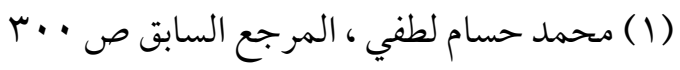

$$
\begin{aligned}
& \text { (Y) السنهوري ، المرجع السابق ص } 1791 \text { (بر) }
\end{aligned}
$$

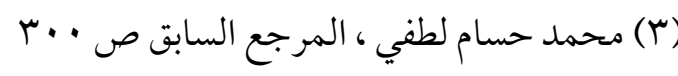

(4) Picard et André Besson, op, cit , p.232,no 141 - Y.Lambert-Faivre 1998, op, cit , p.346,no 510 محمد حسام لطفي ، المرجع السابق ص ..r - - -

$$
\text { (0) السنهوري، المرجع السابق ص •1M ا ف VYr }
$$


ويكون الدفع له من قبل شركة التأمين في حدود مبلغ التأمين الوارد في عقد التأمين"(ووفقا لترتيبهم وأولوياتهمب" (r)

ويكون الدفع لهؤلاء الأشخاص الذين يحق لهم الحصول على التعويض أثر الإبراء

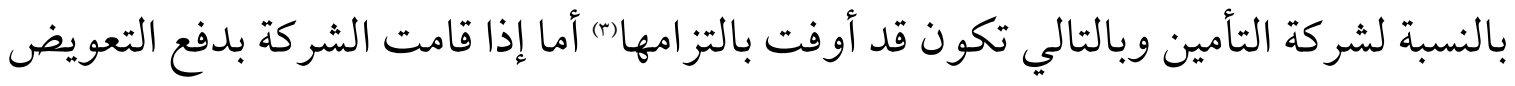
إلى شخص غير مصرح له بقبض هذا المبلغ فإن هذا الدفع لا يعد مبرئا للشركة.

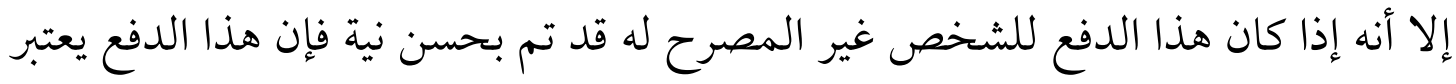

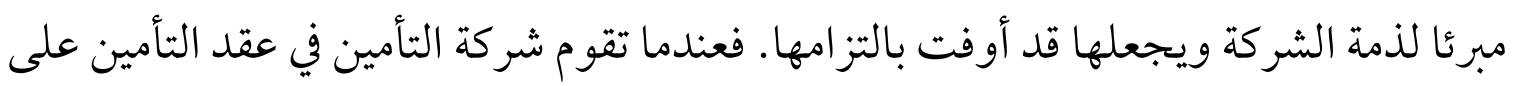

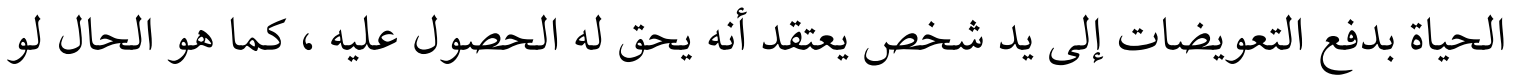

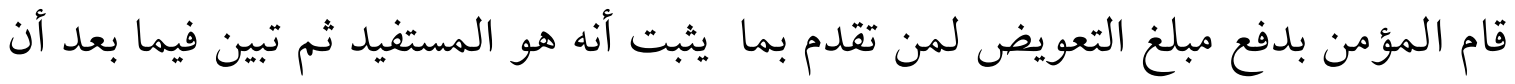
المستفيد شخص أخر ، كما لو غير طالب التأمين المستفيد بمستفيد آخر دون أن يخطر المؤمن أو عين مستفيدا آخر في وصية تركها بعد موته فإن تسليم المؤمن بحسن نية للمستفيد الظاهر يكون مبرئا لذهته ويرجع المستفيد الحقيقي على المستفيد الظاهر (i)ويكون سداد المؤمن مبرئا له ويحررهه من التزامه لأنه كان حسن النية).

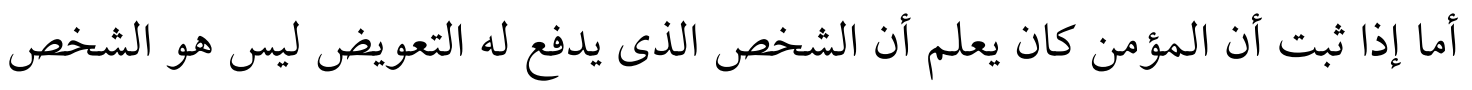
المستحق لاستلام التعويض ، في هذه الحالة فإن هذا الدفع ليس له أي تأثير ويظل المؤمن لهن

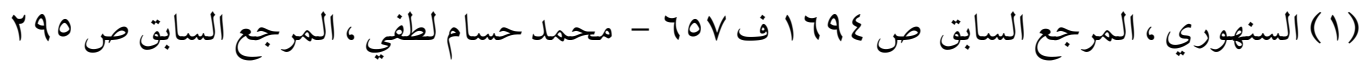
(2) Henriette E. Kameni,op , cit ,p.73

Khalifi Taghzouti, et d'autres, op , cit, p.21 (r)

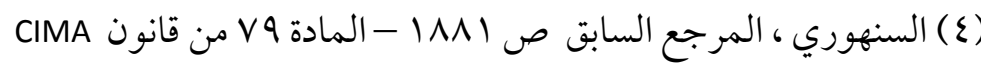
(0) ومن قبيل السداد المبرئ لذمة شركة التأمين السداد الذى تقوم به بحسن نية قبل أي معارضة من الدائين الممتازين أو حاملي الرهن العقاري . 
ملتزما تجاه المستفيد الحقيقي ، ومع ذلك فإنه من الصعب من الناحية العملية أن يقوم المؤمن بالدفع غير الواعي للتعويض ليد شخص غير مصرح له في استلامه ؛ خاصة وأنه محترف وله خبرته في مجال التأمين".

\section{رابعا : حسن نية المؤمن في الالتزام بعدم إفشاء أسرار المؤمن له.}

رأينا فيما سبق أنه لا وجود لعقد تأمين بدون معلومات ، فالمؤمن له ملتزم بالإدلاء بكافة

$$
\text { المعلومات المتعلقة بالخطر التي يطلبها منه المؤمن في الاستبيان . }
$$

بمجرد تلقى المؤمن البيانات التي يطلبها من المؤمن له ، سواء كانت بيانات شخصية أو بيانات موضوعية متعلقة بالمخاطر ، فإنه يصبح أمينا على هذه البيانات التي أودعها لديه المؤمن له باعتبار هذه البيانات أسرار تخص الأخير • ما يهمنا هو مدى أحقية المؤمن في التصرف بحرية مطلقة في الكشف عن أسرار المؤمن له وذلك لأطر اف خارج عقد التأمين وبخاصة إذا كانت هذه الأطراف تعمل في مجال التأمين أو قريبة منه ؛ خاصة شركات التأمين الأخرى التي لها علاقة تجارية متميزة مع شركة التأمين و التي قد تطلب منها الكشف عن المعلومات المتعلقة بعقد التأمين وفي هذه الحالة تصبح شركة التأمين واقعة بين مصلحتها في الإفصاح والتزامها بالحفاظ على أسرار المؤمن له . الواقع أن المؤمن يبقى في كل الأحوال أمينا على أسرار المؤمن له المودعة لديه وليس مالكا لها(()وهذا يعنى أن المؤمن يجب ألا يفشى أسرار المؤمن له ؛ باعتبار ذلك جزء من مبدأ الولاء التعاقدي الذى يتطلب المعاملة بالمثل، فحماية المؤمن لأسرار المؤمن له تعد واجبا أخلاقيا يعزز احترام الثقة المشروعة في شركة التأمين ويعمل على التوازن العادل الذى تحدده ضرورات الحياة في المجتمع وترجمة للقول المأثور " لا تفعل بالآخرين ما لا ترغب في

(1) Khalifi Taghzouti, et d'autres, op , cit, p.21 - Henriette E. Kameni op , cit ,p.76

(2) Camila HABOUBI ,op, cit, no 793 


\section{قيامهم به ضدك "(1)}

كما أن هذه الحماية لأسرار المؤمن له لا تقف عند قيام شركة التأمين بالسلوك السلبى بعدم الإفشاء ، وإنما يجب عليها بذل كل جهد لمنع الغير من الوصول لهذه الأسرار ، وهذا الالتزام يتم فرضه من حيث المبدأ على كل الذين لديهم إمكانية الوصول إلى أسرار المؤمن

مع ذلك فإننا إذا أخذنا هذا الالتزام من الجانب الأخلاقي فإنه لا عقاب عليه حيث إن وضع الشخص تحت رعاية واجب الضمير والشرف والو لاء لن يسمح باتخاذ إجراء قانوني ، ومع ذلك فإن القواعد الأخلاقية - كما سبق القول - تصبح التزاما قانونيا إذا تم دمجها بموجب النصوص القانونية ، لذلك فإن هذا الالتزام بالسرية في عقد التأمين يتحول إلى التزام مدني عندما تكون أسرار المؤمن له قد جمعت لتتكيف مع السياق الذى أوكلت إليه في بيان

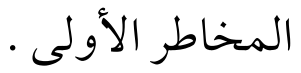
وهذا الالتزام بحماية أسرار المؤمن له يتأسس على حسن النية التي مكنت من تطوير الالتزامات القانونية للعقد ، والذى سيتم تطبيقه في كل مراحل العقد سواء مرحلة المفاوضات أو مرحلتي إبرام وتنفيذ العقد (r).

في مرحلة المفاوضات يفرض التزاما قانونيا يهدف إلى ضمان الكشف عن المعلومات اللازمة كي يتم التعاقد المحتمل ، فيكشف المؤمن له عن أسراره من خلال إعلان بيان المخاطر الذى يعتبر بمثابة أساس للتوضيح النهائي للعقد . في هذه المرحلة يمكن تصور تغيير شركة التأمين لرأيها فتقطع المفاوضات وذلك بعد حصو لها على أسرار المؤمن له ، في هذه الحالة يستطيع المؤمن له فرض الصمت على شركة 
التأمين التي لم تعد تتمتع بوضع الشريك المتعاقد المستقبلي ويتم الاحتفاظ بسرية بيانات المؤمن له لأجل غير مسمى (1)وتقوم مسئولية شركة التأمين في حال الكشف عن هذه الأسرار فتوقع العقوبة على شركة التأمين بغض النظر عن نيتها سواء كان الكشف عن قصد أو عن إهمال وبحسن نية (r)

مع ذلك فإن السرية إذا كانت محمية باتفاق تعاقدي بين المؤمن له والمؤمن فإنها تكون أكثر فاعلية وحماية(r)فإذا لم يتم إبرام أي اتفاق يتعلق بالحفاظ على سرية العقد فإن هذا الالتزام ينشأ ضمنيا وموضوعيا من العقد ويتخذ شكل التزام عقدي تبعي حيث يوجد جزء من الالتزامات يكون نتيجة للمساواة أو مستمدة من العرف أو القانون حتى ولو لم يفكر أطر اف العقد في ذلك وهذه الطريقة تحدث توسعة كبيرة في مجال التقصير العقدي والتي من شأنها أن تحمى أسرار الشريك المتعاقد ؛ لذلك لم يعد هناك شك في أن الالتزام بالسرية كالتزام على شركة التأمين ينبع من مبدأ حسن النية الذى يتطلب عدم الكشف وربما عدم الاستخدام إذا لم يتم توقيع العقد (8) .

الالتزام بالسرية التزام فرعى تفرضه السوابق القضائية على المهني والذى يفترض مسبقا التزامه بعدم نقل المعلومات التي جمعها سواء وقت التحضير للعقد أو وقت تنفيذه(مكما أنه التزام تفرضه القوانين. كما أن الحفاظ على سرية وجود العقد قد يكون ضرورة ملحة من قبل طرفي عقد التأمين

(1)Cass. com., 21 novembre 2000, n 98-17.783 et Cass. com., 20 octobre 1998, n 96-18.596

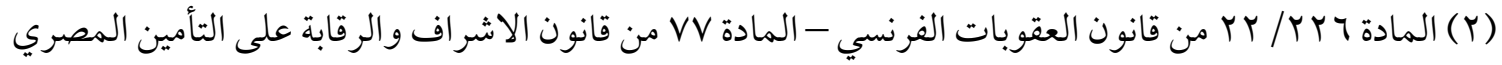
(Y) في الممارسة العملية الحل الأمثل لحماية البيانات هو اتفاقية السرية أو ما تعرف باتفاقية عدم إفشاء الأسرار

$$
\text { خاصة في حياة الأعمال حيث يكون هناك الكثير من المعلومات والبيانات الحساسة. }
$$

(4) Camila HABOUBI, op, cit, no 806

(5) CA Riom, 30 mars 1995, JCP G 1995, IV, 2595 
وعلى ذلك فالمستفيد من المعلومات يلتزم بسرية وجود عقد التأمين ، وكذلك كل ما هو متعلق به ، كالمستندات المقدمة من المؤمن له التي تكون سلاحا حقيقيا في عالم الأعمال حيث يمكن أن تكون بعض المعلومات ذات أهمية كبيرة في عمل المؤمن له ؛ كالبيانات المالية وأفكار التطوير للمشاريع المختلفة ،والابتكارات التقنية ،وخطط المصانع أو الشركات التجارية ، أو تفاصيل عن الممتلكات ووسائل حمايتها وأنظمة الإنذار

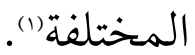

ويجب ألا تقتصر حماية أسرار المؤمن له على محتوى العقد وفقط ، بل يجب على شركة التأمين تعزيز استمرارية تدابير حماية البيانات التي حصلت عليها من المؤمن له لهاباتخاذها الاحتياطات اللازمة للحفاظ على سرية المعلومات؛ وتحقيقا لهذه الغاية يتطلب من شركة التأمين عمل جميع الوسائل اللازمة لرعاية سرية العقد وضمان عدم وجود عقود مبرمة أو في

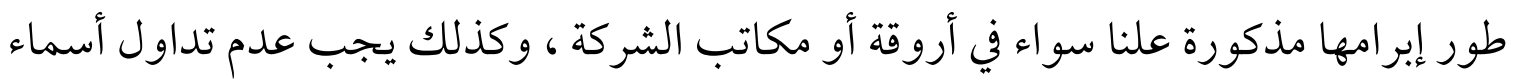

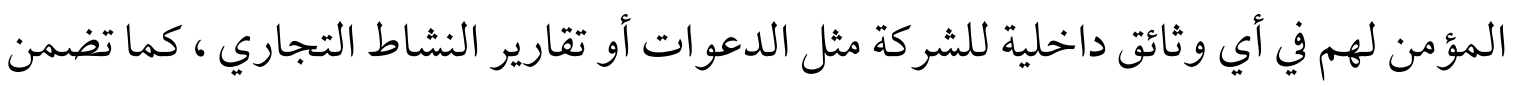
الشركة وجود عقد التأمين في أماكن سرية لا يمكن الوصول إليها إلا لأعضاء معينين في تهري

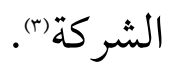
وإذا كان المقصد من التزام السرية هو حماية المؤمن له فيجوز الإفصاح عن هذه الأسرار بشرط موافقته المسبقة، ومع ذلك فإن الأسرار الطبية لا يمكن الإفصاح عنها أو تداولها بين شركات التأمين حتى لو وافق المؤمن له على ذلكة).

(1) ويكون هذا الالتزام من خلال وضع بنود تعاقدية من أجل التمتع بالسرية بشكل أفضل سواء فشلت

$$
\text { المفاوضات أو تم ابرام العقد وحتى بعد انتهائه }
$$

(2) Camila HABOUBI ,op, cit, no 808

(3) Ibid, no 817-818

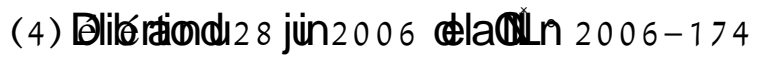


كذلك في بعض الأحيان يبدو أن تداول أسرار المؤمن له أمر لا مفر منه حيث يوجد حالات مسموح فيها بتداول أسرار المؤمن له دون الحصول على موافتته فيمكن تداول المعلومات بين شركات التأمين في الأحوال التي تساعد شركة التأمين على مو اصلة نشاطها من خلال السيطرة المطلقة على المخاطر ، حيث تقوم شركات التأمين بإنشاء قاعدة بيانات واحدة يمكن الوصول إليها من قبل جميع الشركات في وقت واحد بخصوص حاملي الوثائق المشبوهين أو الذين تكثر حو ادثهم وسرقاتهم خاصة بخصوص مكافحة الاحتيال في التأمين على الحياة ، وكذلك الحال بالنسبة للتأمين المشترك حيث يعتبر الكشف عن البيانات جزءا من تقاسم عقد التأمين (1). - من كما يجب على شركة التأمين الإفصاح عن محتوى عقد التأمين متى كانت هناك مصالح أعلى من تلك التي يتطلبها الأطراف المتعاقدة حيث يغلب الصالح العام على الصالح الخاص ومن قبيل ذلك الكشف عن عقد التأمين للإدارة الضريبية أو للإدارة الجمركية لأجل ممارسة وظائفها(() وكذلك الاستجابة لطلبات السلطات القضائية(") بخصوص الكشف عن الحالة الحقيقية لميراث المؤمن له وكذا في الأحو ال الى يكون فيها المؤمن له ضالعا في نشاط

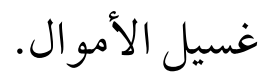

(1) Camila HABOUBI ,op, cit, no 845-849

(2) Ibid, no 857 


\section{المبرمث الثخالث \\ حسن التبة كوسيلة للحفاظ على الثوازن المالي لعقد التأمين}

يجب على كل من المؤمن والمؤمن له إظهار حسن نيتهما الدائم سواء وقت التفاوض على العقد أو وقت إبرام العقد ،أو أثناء تنفيذه وحتى عندما يحدث الحادث المؤمن ضده. وحسن النية الدائم وبخاصة في المعلومات المقدمة من طرفي عقد التأمين يهدف إلى ضمان المساواة بينهما ؛ ليكون كل طرف على دراية كاملة بعلاقته التعاقدية وإمكانية الدفاع عن مصالحه. فشركة التأمين التي تقوم بعملية التأمين تهدف من وراء ضمانها للمخاطر إلى تحقيق ربحية من هذه الأعمال ، كما أن المؤمن له يرغب في نقل المخاطر المحتملة لشركة التأمين في مقابل دفع القسط المناسب ، وهذه المقاصد من طرفي عقد التأمين ما هي إلا مصالح مالية ، وحسن النية هو الوسيلة للحفاظ على هذه المصالح المالية والحفاظ على الاستقرار المالي لعقد التأمين ·

فحسن النية هو الوسيلة للحفاظ على توازن العلاقة التعاقدية بين المؤمن والمؤمن له (1)وبالتالي يتم التأكيد على أن ولاء المؤمن سيسمح للمؤمن له باختيار بوليصة التأمين التي تناسبه ، في المقابل فإن صدق المؤمن له سيؤدى إلى قيام المؤمن بحساب قسط التأمين الذى يتعين دفعه وبحيث يسمح هذا القسط من خلال تجميعه مع أقساط العملاء الأخرين لشركة التأمين بتعويض المؤمن له في حال حدوث الخطر المؤمن منه(). إن هذا بالطبع هو التوازن

حيث يعتبر مبدأ حسن النية آلية من آليات تحقيق التوازن العقدي وعدم الاخلال به ( أمينة سي عمر وتركية

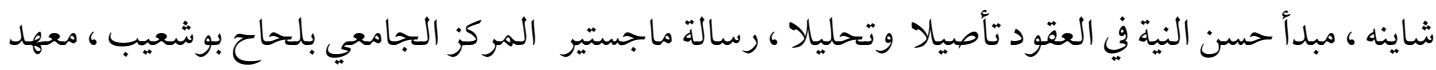

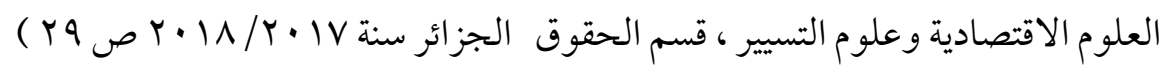

(Y) يتميز عقد التأمين بأنه لا يحمى المؤمن له بعينه بل يحمى كل المؤمن لهم مجتمعين خاطر نورى حمد

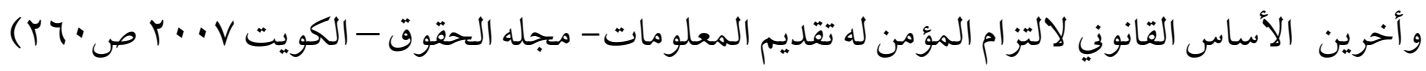


المالي لعقد التأمين حيث يشكل العقد عملية اقتصادية يحركها مبدأ حسن النية(1) المطلوب كشرط ضروري وقت إبرام العقد ويتم من خلال افتراض حسن نية أطر اف عقد التأمين .

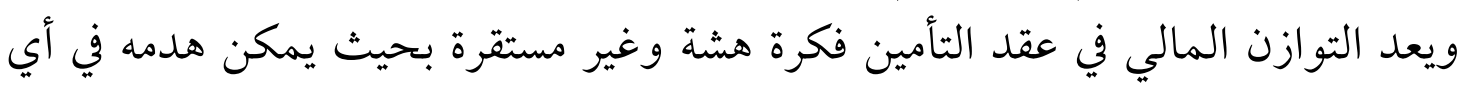
وقت (r). فاختلال التوازن يمكن أن ينتج من وجود ظروف جديده لم تكن موجوده أثناء إبرام عقد التأمين وفي هذه الحالة يتم استعاده هذا التوازن بعد الإعلان عن هذه الظروف الجديدة أثناء تنفيذ العقد كما يمكن أن يكون عدم الاستقرار ناتج من فعل أحد المتعاقدين وفي هذه الحالة إذا تم اكتشاف الخلل في التوازن بسبب وجود الخطأ من أحد المتعاقدين فإن عقوبات هذا الخطأ إذا كان قد ارتكب عن غير قصد تكون خفيفة وفي الغالب تكون تدابير فقط تهدف إلى حماية التوازن المالي بين مختلف أطراف العقد ، وذلك على عكس الأخطاء التي تتم بسوء نية و التي تتميز أحكامها بكونها عقابية. وسوف نتناول في هذا المبحث هذه الأحكام على النحو التالي : المطلب الأول : التوازن المالي في عقد التأمين الناشئ عن افتراض حسن النية. المطلب الثاني : الخطأ المرتكب بحسن نية والتوازن المالي في عقد التأمين.

\section{المطلب الأول}

\section{التوازن المالي في عقد التأمين الناشئ عن افتراض حسن النية} إن عدم التوازن أمر متوقع في عقد التأمين حيث يمكن تصور وجود خلل طبيعي بين المؤمن والمؤمن له ، وهذا الخلل ناتج من طبيعة عقد التأمين باعتباره عقد من عقود

$$
\text { (1) (1) (أمينة سي عمر وتركية شاينه ، المرجع السابق ، ص } 9 \text { ب. }
$$

(Y) حيث إن هذا التوازن قد يختل لظروف معينة أو بفعل أحد المتعاقدين. أمينة سي عمر وتركية شاينه المرجع

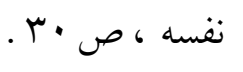


الإذعان") الذى يضع المؤمن شروطه مسبقا وما على المؤمن له إلا الانضمام له ، وهناك احتمال كبير أن يقدم المؤمن العقد والبنود التي في مصلحته الشخصية. كما أن هذا الخلل يمكن أن يتتج بسبب نوعية المتعاقدين ، فعقد التأمين من عقود الاستهلاك أحد طرفيه هو المؤمن المحترف الذى يعرف كل شيء عن صناعة التأمين ، و الطرف الثاني هو المؤمن له المستهلك والذى لا يعرف شيئا عن صناعة التأمين ؛ لذلك هناك احتمالية كبيرة لعدم المساواة بين المتعاقدين · فإذا تم التركيز في هذين السبيين لإمكانية نشوء خلل في التوازن العقدي فمن المؤكد القول بأنه لن يكون هناك عقد تأمين ، وأمام هذا الوضع المخيف فقد تدخل المشرع من خلال افتراضه حسن النية بين المتعاقدين والذى ينقل المتعاقدين إلى فكرة المساواة التعاقدية(r). فيعتبر مبدأ حسن النية من المبادئ العامة التي تسرى على كل العقود ، وفي ذلك يقضى نص المادة ع • 11 مدنى فرنسي بوجوب التفاوض على العقود وإبر امها وتنفيذها بحسن نية ، كما يقضى نص المادة ^ع ا مدنى مصري(r)بأنه يجب تنفيذ العقد طبقا لما اشتمل عليه وبطريقة تنفق وما يو جبه حسن النية. فإذا كان التفاوض على العقد وإبر امه وتنفيذه يتطلب مراعاة حسن النية إلا أن عقد التأمين أكثر حاجة من العقود الأخرى إلى حسن النية والتي تلعب دورا هاما في انعقاده وتنفيذه أكبر

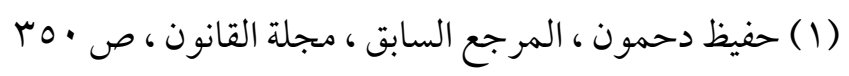
(Y) المادة ع • ال من القانون المدني الفرنسي والتي جعلت حسن النية مطلوب في جميع مراحل العقد سواء

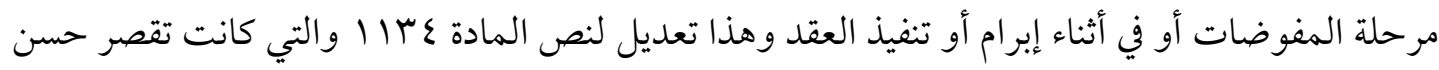
النية على تنفيذ العقد.

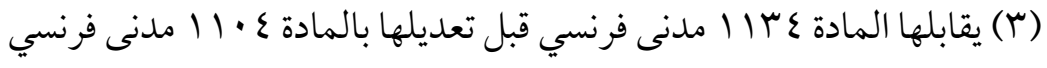




$$
\text { من الدور الذى يقوم به في أي عقد آخر (1). }
$$

فبحسن النية يتم تحقيق التوازن الأساسي المستقر لعقد التأمين وفي حال حدوث خلل في

هذا التوازن فإنه يمكن مراجعته في أي وقت وفي أي مرحلة من مراحل تنفيذ العقد (r).

\section{الفرع الأول \\ التوازن الأساسي عند إبرام عقد التأمين}

عندما يجتمع طرفي عقد التأمين لإبرام عقد التأمين يتحول الخلل الطبيعي في التوازن التراسي

العقدي بسبب الإذعان إلى توازن مصطنع يشكله أطراف عقد التأمين ويكون هذا التوازن قائم على أسس معينة هي افتراض حسن نية طرفي العقد كافتراض قانوني ، إضافة إلى أساسه التعاقدي الناتج من إر ادة طرفيه.

$$
\text { 1 - افتر اض حسن النية }
$$

ينتج التوازن الأساسي لعقد التأمين من الافتراض القانوني بحسن نية طرفي العقد فإذا كان عقد التأمين عقد متعدد الأطراف ( مؤمن - مؤمن له - ومستفيد ) وهو عقد زمنى ، باهظ الثمن احتمالي ، انضمامي حيث ينضم المؤمن له للمؤمن في وثيقة التأمين ، كذلك هو عقد بحسن نية ، بل إن حسن النية هو السمة الأساسية التي تحكمه ، فيفترض فيه ودائما حسن النية وعلى من يدعى خلاف ذلك إثبات العكس . فيفترض أن يكون المؤمن له عادلا وصادقا في أقو اله وتأكيداته ، فيكون صادقا عندما يقترح على المؤمن ضمان مخاطر معينة ، ففي خلال مرحلة المفاوضات وقبل إبرام العقد يجب أن تكون كلماته وتأكيداته ومعلوماته التي أدلى بها في الاستبيان صادقة وفقا لافتراض قانوني في

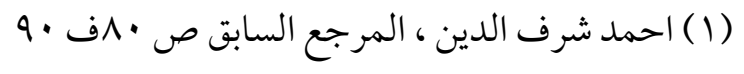

(2) Henriette E. Kameni,op,cit ,p.80 
فعقد التأمين عقد أمانه حيث تعتمد شركة التأمين على أقو اله بثقة بالغة في تقييم المخاطر التي ستضمنها (r)، فحساب تكلفة التأمين يعتمد على تصريحات المؤمن له وتستطيع شركة التأمين دعم هذه التصريحات بعدة وسائل منها زيارة المؤمن له أو طلب مستندات معينة منه مثل شهادات الميلاد ، وعقود الملكية المسجلة ، أو دفاتر التفتيش على أماكن العمل ، وما إلى ذلك من المستندات بهدف زيادة قناعتها بشكل أفضل (r). ويمكن لشركة التأمين بعد ذلك رفض طلب التأمين حماية للعملاء وذلك بسبب طبيعة المخاطر أو طبيعة الشيء أو بسبب الشخص ذاته. كما يمكن لشركة التأمين قبول دعم المخاطر والتأمين عليها ، وفي هذه الحالة تكون الشركة قد وثقت تماما في أقوال وتصريحات المؤمن له ، فيتم حساب القسط الذى سيدفعه المؤمن له وفقا للمعلومات التي قدمها الأخير (s). كما تستطيع شركة التأمين إضافة مخاطر أخرى إلى المخاطر الرئيسية ويمكن أن تكون هذه المخاطر أكثر خطورة من المخاطر الرئيسية. عموما فإن حساب قسط التأمين يعد أمرا هاما جدا باعتباره التمثيل المالي للمخاطر

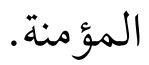

(1) وهذا يعني أن كلمات المؤمن له تعتبر حقائق مطلقة تخضع لبعض الشيكات التي يجب على المؤمن القيام بها كمحترف. أو كما يعبر عنها الفقه الغربي باعتبارها ( انجيل الكلمات ) lbid, p.84

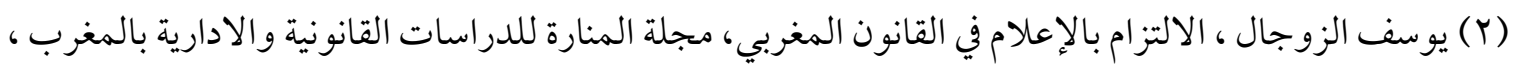

(3) Henriette E. Kameni, op , cit , p.84

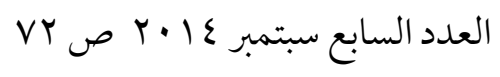

(ع) فعلى سبيل المثال في التأمين على الحياة يتم استخدام معلومات متعلقة بعمر المؤمن له وحالته الاجتماعية وحالثه المهنية وعدد السنوات التي يرغب في ارتباطه بعقد التأمين. 


\section{r - - الأساس التعاقدي للتوازن الأساسي للعقد}

إضافة إلى الأساس القانوني المستمد من حسن النية فإن التوازن الأساسي في عقد التأمين مبرر أيضا بطبيعته التعاقدية ، فإذا كان الالتزام العقدي يقوم على أساس التوازن بين الالتزامات المتقابلة بين أطرافه بحيث يفي كل طرف بما التزم به في الحدود التي ارتضاها بإرادته الحرة"(1)فإن عقد التأمين الذى تم اعتماده من أطرافه يعد قانونا للأطر اف ، والتوازن ينتج من هذا العقد باعتباره شريعة المتعاقدين التي اتفقوا عليها. إن عدم المساو اة الطبيعية للأطر اف في عقد التأمين الناتجة من كونه عقد إذعان حيث يوجد مؤمن محترف ومؤمن له مستهلك يقابله إنشاء أطر افه لمساواة مرجوة."(). في الواقع يخضع الطرفان للقانون الذى وضعوه لأنفسهم ، المؤمن له- المستهلك- يلتزم بوثيقة التأمين الموضوعة مسبقا من قبل المؤمن بمحض إرادته ، حيث يتمتع بحرية الانضمام لعقد التأمين من عدمه ، فهو لا يطيع إلا نفسه ، ولا يزال حرا يقف على قدم المساواة مع شركة التأمين المتعاقدة معه. إننا إذا اعتبرنا عقد التأمين عملية تتم بين مؤمن محترف ومؤمن له مستهلك فإنه سيكون عقدا بين طرف قوى وطرف ضعيف ، وسيكون هناك صراع حقيقي من قبل أطر افه وإساءة قوية للطرف الضعيف ، ولن يتمكن الطرفان من العيش في وئام حقيقي إلا إذا تنازل كل منهما عن بعض من سلطاته لسلطة عليا هي المصالح المشتركة .

فعقد التأمين مظهر من مظاهر الإر ادة المشتركة ، و الحفاظ على المصالح المشتركة لطرفيه يأتي لاستعادة عدم المساواة الطبيعية الناتجة من كون أطرافه مؤمن محترف قوى يعرف كل

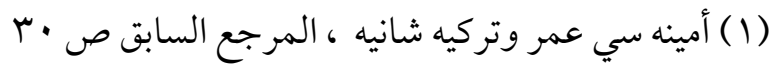

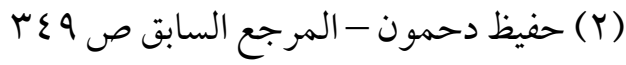


شيء عن صناعة التأمين ومؤمن له مستهلك ضعيف عديم الخبرة(()لا يعرف أي شيء عن صناعة التأمين (() هذه الإر ادة المشتركة هي أساس المبادئ التعاقدية العظيمة المطورة(). r- التوازن الناتج عن الحرية التعاقدية. إن الحرية التعاقدية لأطر اف عقد التأمين تكشف عن المبادئ الرئيسية لهذا العقد وهي قائمة على أساسين هامين هما المساواة ، والتوازن بين الأطراف . وعقد التأمين يتشكل من خلال تلبية رغبات المؤمن والمؤمن له ، وكل منهم يعبر عن مو افقته لإبرام العقد ؛ لذلك تعد إرادة الأطراف مصدر الحقوق التي تم إنشاؤها ، وهي التي تجعل كل طرف يتحمل ما وافق عليه بإراداته الحرة ، ومن هنا جاءت المساواة والتوازن حيث لا إجبار على أي طرف لإبرام العقد ، فوجود الحرية التعاقدية تجعل المتعاقدين متساويين ولو كانت هذه المساواة مجردة). فالعقد تعبير عن موافقة اثنين أو أكثر من أفراد القانون ، وإن كان هناك بعض العقود التي

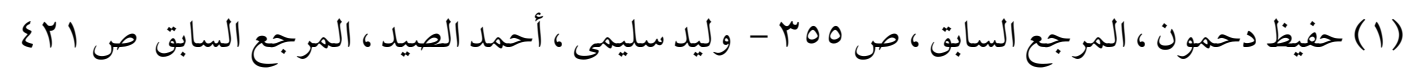

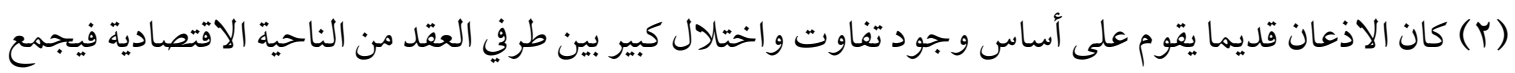
عقد الاذعان بين طرف ذي قوة ومكانة اقتصادية كبيرة يتحكم من خلالها في دقة التعاقد فيبرمه وفقا لشروطه

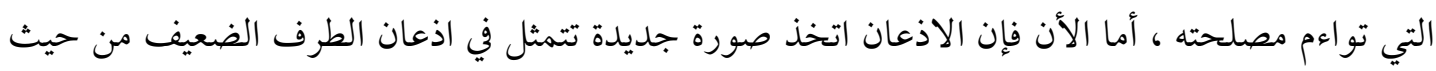
الدراية والعلم للطرف الأخر ذي الخبرة والمعرفة فيبرم معه العقد وهو على جهالة كاملة أو جزئية بالجوانب

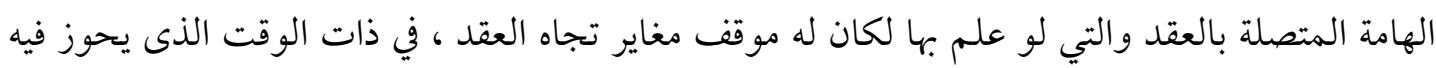
الطرف الأخر كافة المعلومات التي يمكن أن تبصره بتلك الجوانب .( مريم طويل ، قانون السوق وفكرة

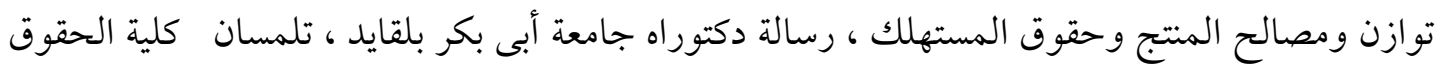

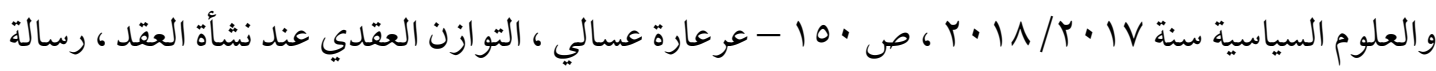

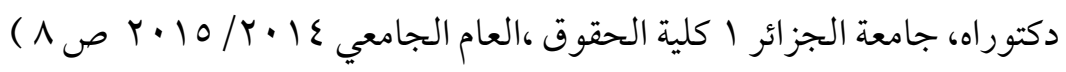

(3) Henriette E. Kameni, op , cit , p.86

$$
\text { (ع عرعارة عسالي ، المرجع السابق ، ص 0-7 (1) }
$$


يتم إبرامها على حساب أحد الطرفين على الرغم من وجود إرادتهما ، إلا أنه فيما يتعلق بعقد التأمين فإن ذلك لا يمكن أن يسبب اختلال التوازن بينهما. فإذا كان الخطر عنصرا جوهريا في عقد التأمين وهو ذو طابع احتمالي يمكن أن يحدث ويمكن أن لا يحدث ؛ لذلك يصعب حساب التوازن المالي الموجود بين طرفي عقد التأمين أثناء إبرامه لأنه لا يعرف ما إذا كان الخطر سيتحقق أم لا ، ولا يعرف وقت تحققه ، ولا مقداره ، وبالتالي لا يمكن لأحد القول بأن أحد الطرفين قد جار على حقوق الطرف الثاني لذلك لا يو جد ضرر فعلى في عقد التأمين · يضاف إلى ذلك فإن تبرير وجود التوازن المالي في عقد التأمين موجود من خلال قواعد القانون الطبيعي واحترام الكلمة المعطاة والتي تحث طرفي عقد التأمين على تنفيذ التزاماتهما التي فرضتها عليهم إر ادتهما المتو افتة).. ع - التوازن الناتج من الأحكام القانونية. في سياق الدور الذى يجب أن يقوم به المشرع لحماية أطراف عقد التأمين نجد أن المشرع قد تدخل لاستعادة المساواة بين أطراف العقد وذلك في الأحوال التي يعربون فيها بشكل سيء عن رغبتهم في التعاقد ؛ لذلك وبهدف منع الانتهاكات المحتملة الناتجة عن حرية التعاقد نجد المشرع قد وضع بعض الأحكام الوقائية والتي اتسمت باتصالها بفكرة النظام العام والتي تهدف إلى الحد من الخلل القائم بين أطراف العقد كونه عقد إذعان(r)ووجوب خلق الإرادة المشتركة للمتعاقدين لعقد متساوي فيما بينهما ؛ لذلك أحاط المشرع رغباتهم بأحكام لا يمكن الانتقاص منها لما فيه خير الجميع ومصلحتهم . والمشرع لم يتدخل هنا لجعل الحرية التعاقدية تختفي ، فلا مساس بالحرية

(1) Henriette E. Kameni, op , cit ,p.87 
التعاقدية(1) إنما تدخله جاء لإتقان الأطراف حريتهم التعاقدية ، فأعطى كل طرف ظروفا عادلة ومتكافئة حماية للطرف الضعيف ودون الإضرار بحقوق الطرف الآخر. ولضمان احترام أطراف عقد التأمين للأحكام الوقائية التي وضعها المشرع وضع عقوبات صارمة على مخالفة هذه الأحكام ، ومن أمثلة هذه الأحكام الوقائية حظر المشرع للشروط التعسفية(1)وتقرير البيانات الإلزامية في وثيقة التأمين("(r)وضع الشروط المتعلقة بمدة عقد

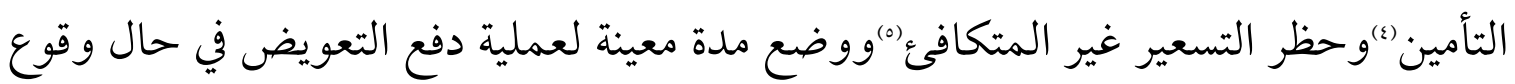
الخطر

ه- بيان التوازن الأساسي خلال إبرام عقد التأمين. في وقت إبرام عقد التأمين تعتمد شركة التأمين على بيان المؤمن له المحتمل لتقييم المخاطر التي يجب أن تتحملها إذا وافقت على ضمان المخاطر وكذلك تحديد قيمة القسط

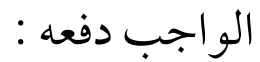

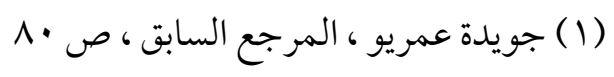

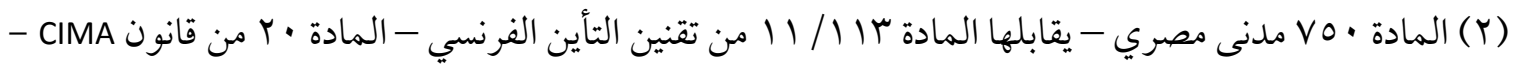

$$
\text { المادة س 91 موجبات لبناني }
$$

تصدت كافة التشريعات لهذه الشروط المجحفة ونبذت العقود التي تتضمنها منعا للآثار السلبية الوخيمة التي تلحق الطرف المذعن من هذه البنود التعسفية التي تجعل التزامات الطرفين غير متكافئة تعكس انعدام التوازن

$$
\begin{aligned}
& \text { في العقد. (دحمون حفيظ المرجع السابق ، ص ror) } \\
& \text { (Y) المادة Y / / / / من تقنين التأمين الفرنسي }
\end{aligned}
$$

(ع ) ومدة عقد التأمين من ضمن البيانات الإلزامية التي يجب وجودها في وثيقة التأمين ( المادة Y | I / ع عرنسي ) (0) المادة ^§ مكرر / T من اللائحة التنفيذية لقانون الإشر اف والرقابة على التأمين (7) المادة 1) مكرر / T من اللائحة التنفيذية لقانون الإشراف والرقابة على التأمين - وفي القانون الفرنسي المواد

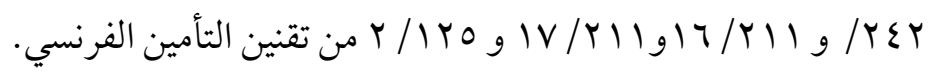




\section{(أ) قبول المخاطر وفق تصريحات المؤمن له المحتمل.}

عندما يأتي عميل محتمل إلى شركة التأمين ، أو عندما تذهب مبيعات التأمين إلى هذا العميل المحتمل ، وهذا هو الوضع الغالب ؛ حيث إن شركة التأمين هي التي تذهب للعميل يشجعها على ذلك اقتصاد التأمين والمنافسة السوقية")، فإن شركة التأمين تقدم إلى هذا العميل المحتمل استمارة من الأسئلة ( استبيان) متعلقة بالمخاطر التي يرغب العميل المحتمل في ضمان الشركة لها. يجب على العميل المحتمل أن يجيب بحسن نية على الأسئلة المطروحة عليه وأن يكون عادلا ومخلصا في هذه البيانات. يتم طرح هذه الأسئلة المكتوبة بشكل عام بطريقة بسيطة وواضحة ، ومن خلال الرد على هذه الأسئلة المكتوبة تقدر شركة التأمين المخاطر التي يجب عليها أن تتحملها ، كما تتأكد من كون هذه المخاطر احتمالية أم أنها مؤكدة الحدوث من خلال التحقق من طبيعة هذه المخاطر وكذلك تحققها من سلوك المؤمن له المحتمل (()يمكن لشركة التأمين رفض تحمل المخاطر المعنية في حال وجود احتمال ارتفاع حدوث المخاطر ، وبالتالي ستكون الشركة مهلدة بدفع تعويض مرتفع دون الحصول على مقابل لهذا التعويض ؛ لذلك قد تجد الشركة أن من مصلحتها عدم التعاقد وفقا للسلبيات التي تجدها حتى ولو كان المؤمن له المحتمل شخص يتمتع بالنز اهة والإنصاف .

(1) و الذى يقع في الغالب أن طالب التأمين لا يلجأ بنفسه إلى المؤمن ، بل إن الوسيط هو الذى يسعى إليه ليحثه

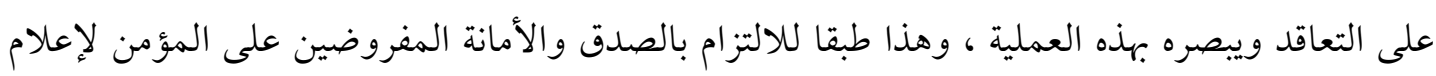

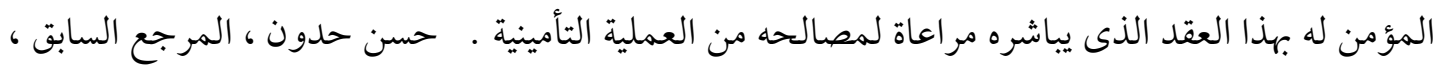
ص94 .

(2) Henriette E. Kameni,op,cit ,p.90 


\section{(ب) تحديد قيمة القسط ومبلغ التأمين}

إذا اختارت شركة التأمين الموافقة على ضمان المخاطر ، فبمجرد صدور هذه الموافقة فيجب عليها تعيين قسط التأمين الذى يتعين على المؤمن له دفعه والذى يجب أن يتناسب في الواقع مع المخاطر المضمونة ، وهذه المبالغ التي يتم جمعها من قبل المؤمنين عن المخاطر المتشابهة ليست فقط من أجل تعويض المخاطر المتكبدة في حال وقوعها ، وإنما يجب أن تقوم بتوليد أرباح لشركة التأمين". وللقيام بذلك يشير المؤمن إلى تصريحات المؤمن له وذلك لحساب التكلفة الصافية لسياسة التأمين التي يضيف اليها المصاريف الناتجة عن أنشطته والنفقات الضريبية والتي تمثل كلها قسط التأمين المستحق على المؤمن له (r). ويختلف حساب أساس تكلفة التأمين وفقا لما إذا كان التأمين على الأشياء أو تأمين على الحياة أو تأمين المسئولية . في التأمين على الأشياء تكلفة التأمين هي قيمة محددة ومعروفة تتو افق مع القيمة السوقية أو قيمة الاستخدام أو القيمة البديلة للشيء ، أما في تأمين المسئولية يعتمد حساب تكلفة التأمين على طبيعة ومدى المخاطر وبحسب ما إذا كان المؤمن له شركة فيتم وفقا لقطاع النشاط الذى تمارسه ، أو فردا فيتم الحساب وفقا لنشاطه المهني وحالته الاجتماعية ، أما في التأمين على الحياة فيتم حساب التكلفة وفقا لسن المؤمن عليه ومدة العقد التي يريدها. بالإضافة إلى تكلفة التأمين الخالص تتم إضافة تكاليف الضرائب ، ونفقات شركات التأمين ومصاريفها للحصول على عملية التأمين وهي الرسوم الحكومية ، ورواتب الموظفين

\footnotetext{
(1) محمد حسام لطفي ، المرجع السابق ، ص ع 17

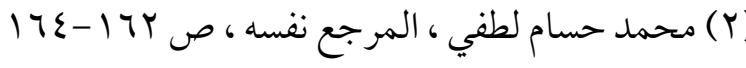


وفو اتير المياه والكهرباء والهاتف وإيجار المقرات ، وهذه النفقات المتعددة تعنى أن الأمو ال التي تتلقاها شركة التأمين من أقساط المؤمن له لا تخصها وحدها وإنما تخص الصندوق المشترك و الذى تديره شركة التأمين باعتبارها مدير التأمين" وليست مالكا لها . فيتم وضع الأقساط المدفوعة والمتعلقة بتغطية المخاطر المتماثلة في صندوق مشترك الغرض من هذا الصندوق تعويض المستفيدين في حال حدوث مطالبات . التبادلية هنا تكون بتجميع عدد كبير من الأشخاص المعرضين لنفس المخاطر (()و الذين يجمعون هذه المخاطر ويقررون تكوين صندوق مشترك يموله المساهمة النسبية لكل عضو على أن يتولى هذا الصندوق مسئولية تسوية المطالبات التي تؤثر على بعضها(r). هذا هو الأساس التقني للتأمين الذى يسمح لشركات التأمين بالوفاء بكافة التزاماتها مع تجنب الوقوع في الإفلاس()ويوضح حقيقة أننا لو أخذنا التأمين بشكل فردى في كل عقد فإن القسط الذى يدفعه المؤمن له لا يمكن أن يسمح أبدا بالتعويض الكامل في حال إدراك الخطر؛ لذلك فإننا إذا فصلنا المؤمن لهم عن بعضهم البعض فلن تستطيع عملية التأمين إفادة المؤمن لهم أو المستفيدين، وكلما زاد عدد المؤمن لهم زاد احتمال دفع شركة التأمين لمبالغ طائلة قد تؤدى بها إلى الإفلاس. من هنا تأتى أهمية تجميع تكاليف التأمين وفقا للاختيار الدقيق للمخاطر المتماثلة (0)ويكون ذلك تجسيدا للمقولة الشهيرة الاتحاد قوة ؛ لذلك فإن شركة التأمين لديها

$$
\begin{aligned}
& \text { (1) احمد شرف الدين ، المرجع السابق ص ع ع ع ع } \\
& \text { (Y) احمد شرف الدين ، المرجع نفسه }
\end{aligned}
$$

(3) Henriette E. Kameni, op,cit,p.96

$$
\begin{aligned}
& \text { (ع ) قريب من ذلك أحمد شرف الدين ، المرجع السابق ص 0؛ ف 0؛ }
\end{aligned}
$$

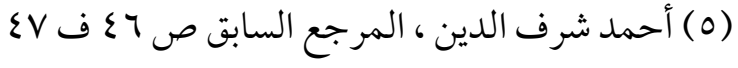


مهمة تنظيم الالتزامات التبادلية ، وأول ما يهمها هو معرفة وتيرة المطالبات ، وفهم الأحداث التي سيكون لها التأثير على الرصيد المالي ، وهذه السيطرة على الأحداث الاحتمالية الناشئة عن الصدفة ليست استثنائية ؛ لأنه حتى الصدفة لها قوانينها (1)و كلما ضاعفنا الخبرات زاد

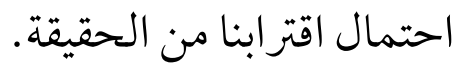

لذلك يمكننا القول بأن مبدأ تجميع المخاطر يحافظ على التوازن بين المطالبات وبين تكلفة التأمين وبشكل غير مباشر على توازن البيئة المالية بين المؤمن والمؤمن له .

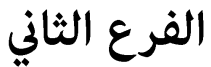 التوازن المالي أثناء تنفيذ عقد الثأمين}

أثناء تكوين عقد التأمين يقوم الأطراف بشكل متساو بتكوين علاقة تعاقدية عادلة ومتوازنة

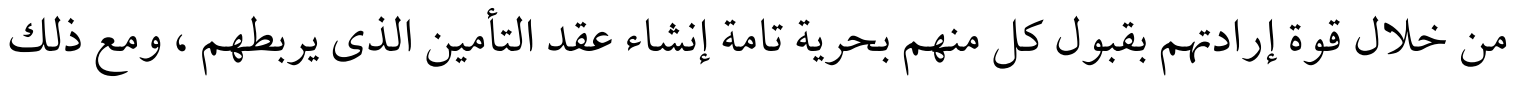
فإن هذا التوازن الذى تم إنشاؤه غير مستقر ؛ لأنه يعتمد على افتراض قانون بسيط وهو حسن نية الأطراف ، وهو افتراض قابل لإثبات العكس ، وكلما تم إثبات عكس ذلك اختل التوازن

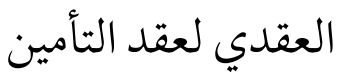

تقرر المادة TV من اللائحة التنفيذية لقانون الإشراف والرقابة على التأمين في مصر أنه " يجب أن تكون

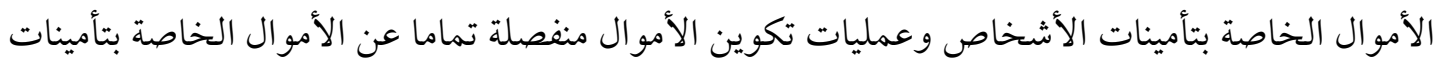

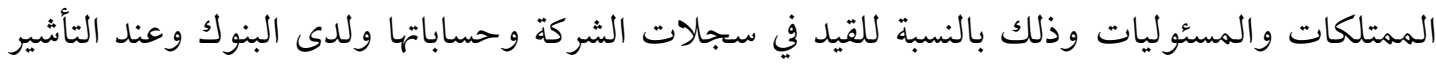

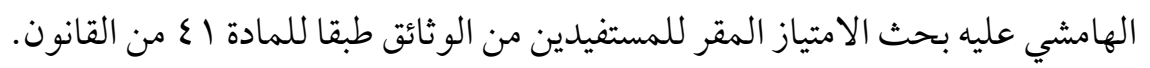

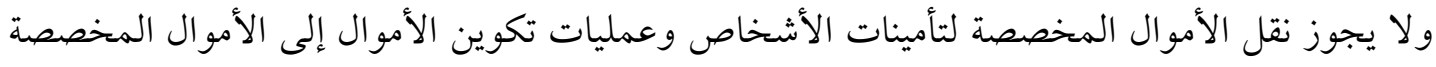

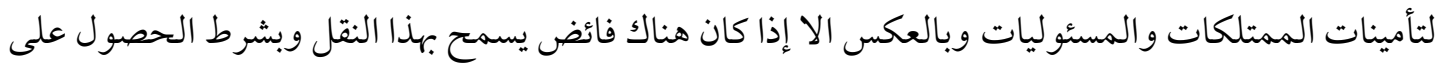

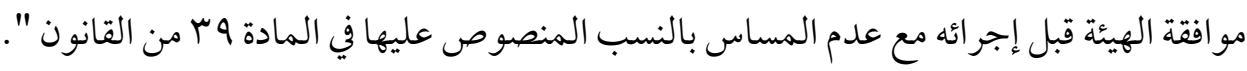
(1) Picard et André Besson, op, cit , p.20,no 11 -Y. Lambert-Faivre ,1998, op, cit p.19,no 13

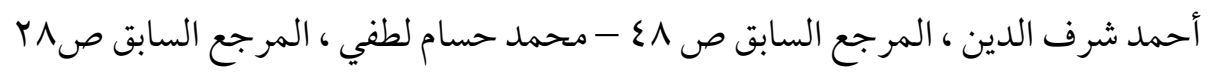




\section{أو لا - اختلال التوازن بسبب خطأ أحد المتعاقدين.}

إن افتراض حسن النية في عقد التأمين افتراض بسيط قابل لإثبات العكس ، وبالتالي يمكن

التشكيك في وجود التوازن الأساسي الذى شكله أطراف التعاقد ، ويمكن أن يتم ذلك بخطأ

$$
\text { متعمد من أحد طرفي عقد التأمين . مت }
$$

فعندما يتم إقامة الدليل على سوء نية المؤمن أو المؤمن له فهذا يدعو إلى التشكيك في

مساواة أطراف العقد ، ويؤكد وجود خلل في موافقة الطرف الثاني ، وقد يؤدى إلى بطلان العقد المبرم ، ويكون إثبات النية السيئة من قبل المتعاقد الذى يدعى ذلك وفقا للقواعد

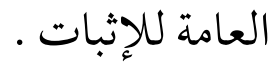

وبهذه الطريقة يجب على شركة التأمين التي تدعى سوء نية المؤمن له أن تقدم الدليل على

ذلك (1) كذلك الحال بالنسبة للمؤمن له الذى يجب عليه إثبات سوء نية المؤمن.

ويجوز للطرف الذى يتمسك بسوء نية الطرف الآخر إثبات ذلك بكافة وسائل الإثبات

دون التقيد بوسيلة محددة .

$$
1 \text { - إثبات سوء النية بأية وسيلة. }
$$

إذا كانت كتابة عقد التأمين وسيلة لإعلام طرفي العقد حقوقهم وواجباتهم ، فيمكن استخدام هذه الكتابة أيضا لإثبات وجود حسن النية من عدمه ، فيعد العقد المبرم وسيلة إثبات ، كما يمكن الاستعانة بالاستبيان()الذى قدم من شركة التأمين للمؤمن له والذى قدم

(1) Cass civ . ii.21 fevrier2013 .n 12-17528

$$
\begin{aligned}
& \text { (r) حيث إن الشركات التي تسعى إلى إثبات سوء نية المؤمن له يجب أن تبدأ من خلال تحليل إجابات الاستبيان }
\end{aligned}
$$

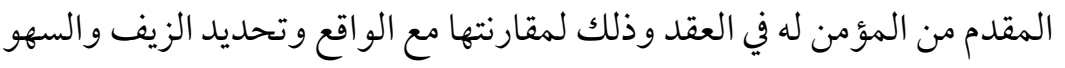

Sameh Borji. Analyse économique et expérimentale de la fraude à l'assurance et audit. Économie et finance, THESE. Université Panthéon-Sorbonne - Paris l, 2006 ,p.22 
من خلاله معلومات عن الخطر وأوصافه(1)كذلك الحال يمكن الاستعانة ببطاقة البيانات الإلزامية المقدمة من المؤمن والمتضمنة معلومات عن الضمانات وتكلفة التأمين

$$
\text { والاستثناءات من الضمان وشروط الإحالة). }
$$

من جميع هذه الكتابات يمكن للمرء أن يحدد بسهولة مدى صحة ودقة هذه البيانات

الصادرة من طرفي عقد التأمين ، فيقدر بسهولة صحة بيانات المؤمن أو المؤمن له ومدى و لاء

كل منهما للآخر.

فعندما يتصرف أحد طرفي العقد عمدا سواء ببيان كاذب أو حتى بصمت مدروس ومتعمد من أجل تجنب التزاماته التعاقدية أو القانونية أو ليتمتع بميزة حقيقية على حساب الطرف الأخر فهذا المتعاقد يكون سيء النية .

إضافة إلى الكتابة التقليدية المتعلقة بعقد التأمين وما قبله من استبيان(م) والإعلانات المتعلقة بالمخاطر وبطاقة المعلومات الإلزامية يجوز للطرف الذى يريد إثبات سوء نية الطرف الآخر أن يستخدم كتابات أخرى كوسيلة للإثبات ؛ مثل تقارير الخبراء ، وتقارير الأطباء ، وأصول التصرفات القانونية ، وتقارير الشركات ، والفواتير ، وقرارات المحاكم فيما يتعلق بالحقائق المتنازع عليها ؛ ولكى يؤخذ بهذه الكتابة كدليل لإثبات سوء نية المتعاقد

(1) يمكن إثبات سوء النية بمساعدة جميع المستندات الصادرة عن المؤمن له وبخاصه إعلان المخاطر خاصة Khalifi Taghzouti, et d'autres, op , cit, p.29 المعقدة منها كالمخاطر الصناعية أو البيئية. (r) يقصد بشرط الاحالة الشروط التي تنص على الاحالة لأحكام أخرى تابعة لعقد التأمين لكن غير واردة في

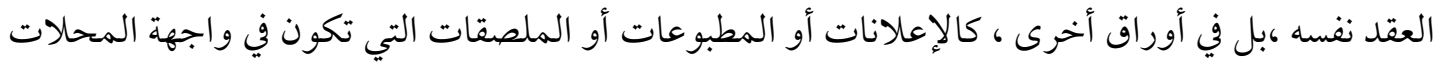

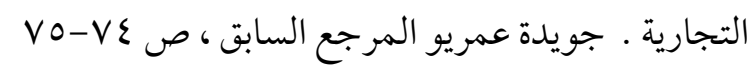

(r) ذهبت بعض الأحكام الفرنسية إلى حد القول ان الاستبيان هو وحده الذى يجعل من الممكن إثبات سوء نية

$$
\text { المشترك }
$$

Civ. 2e, 3 juillet 2014 pourvoi n 13-18760- Cass. ch. mixte, 7 fév. 2014, pourvoi n $12-85107$ 


$$
\text { الآخر يجب أن يتو افر لها الشكل والمضمون المطلوب قانونا”) . }
$$

إضافة إلى الأدلة المكتوبة يمكن استخدام الشهادة كدليل إثبات يقدم أمام المحاكم(ف)فإذا وجد القاضي أن الأدلة المقدمة لإثبات سوء النية غير مقنعة وغير كافية فإنه يرفض القضاء بسوء نية المتعاقد المتهم بذلك ، أما إذا وجد القاضي أن الأدلة المقدمة مقنعة وكافية فإنه يثبت سوء نية المتعاقد ويقضى بالعقوبة المقررة لذلك.

\section{Y - العقوبة الصارمة لسوء نية المتعاقد.}

عندما يتم إثبات سوء نية المتعاقد فإن العقاب الذى يوقع عليه هو بطلان عقد التأمين(")إضافة إلى ذلك يمكن أن يقضى بالتعويض عن الخسارة التي يتكبدها المدعى ، كما يمكن أن يتم تجاوز تلك العقوبات المدنية بتوقيع عقوبة جنائية كذلك إذا شكل فعله جريمة

\section{جنائية.}

\section{r- بطلان عقد التأمين بأثر رجعى مع التعويض.}

عندما يثبت أن أحد أطر اف عقد التأمين تصرف بسوء نية متعمدة فإن جزاء ذلك هو بطلان العقد المبرم بأثر رجعى (8) بالتالي يعتبر أن الطرفين لم يتعاقدا مطلقا وبذلك يظهر أن التوازن الأساسي لعقد التأمين كان هشا واختل بسبب سوء نية أحد الطرفين •

فقي حالة الصمت أو الكذب المتعمد من جانب المؤمن له والذى يتسبب في تغيير المخاطر المؤمنة أو في التأثير على قرار شركة التأمين في قبول التأمين على هذه المخاطر فيكون عقد التأمين باطلا ، ولا يشترط أن يكون لهذا الصمت أو التحريف المتعمد أثر على

(1) Henriette E. Kameni, op , cit ,p.101

(2) Cass civ .1.14 mars 2000 .n 97-19713

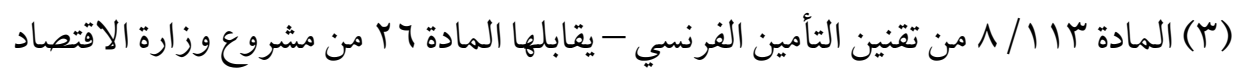

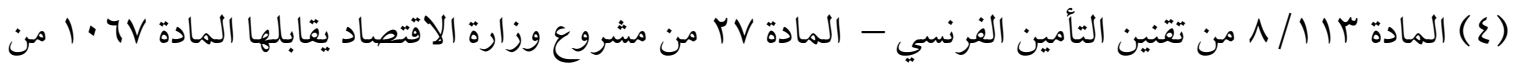

$$
\text { المشروع التمهيدي للقانون المدني }
$$


المطالبة ، كما لا يشترط تحقق المخاطر أو حتى حدوث ضرر من جراء هذا الصمت

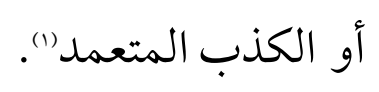

وبالتالي فلا يشترط من أجل توقيع عقوبة البطلان وجود علاقة سبية بين هذا الصمت

$$
\text { ع - الأثر الرجعى له طبيعة خاصة. }
$$

كذلك يكون لبطلان عقد التأمين أثر رجعى ، حيث يعتبر العقد غير موجود من تاريخ إبر امه ويبرر ذلك بأنه إذا تم اعتبار العقد باطلا من يوم تقريره أو القضاء به فذلك يعنى اعتبار العقد نافذا في الفترة السابقة على التقرير ببطلان العقد مما يعنى تعرض المؤمن لمطالبات محتملة لذلك من الأفضل اعتبار العقد باطلا بأثر رجعى .

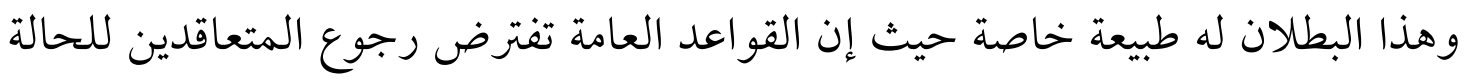

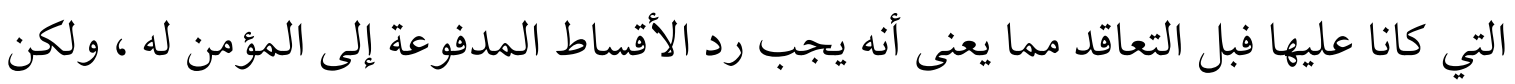
المشرع قرر في هذه الحالة)(متاحفاظ شركة التأمين بالأقساط المدفوعة حتى عن الفترات غير

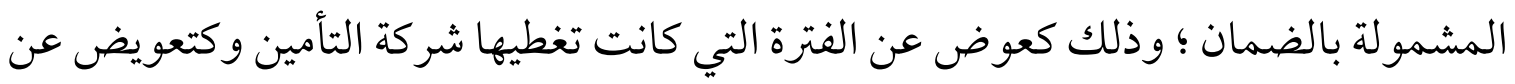
الضرر الذى لحق بها بسبب خرق المتعاقد معها لعقد التأمين ، كما يحق لشركة التأمين في حالة عدم سداد الأقساط أن تطالب المدين بسداد الأقساط التي لم تسدد بسبب خطأه المتعمد ، وهذا يعنى أن البطلان له طبيعة خاصة"). أما بخصوص سوء نية المؤمن فإن النصوص القانونية لم تذكر صراحة العقوبة التي يجب لهبد

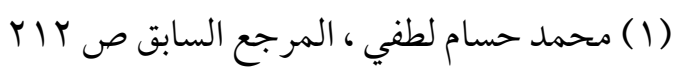

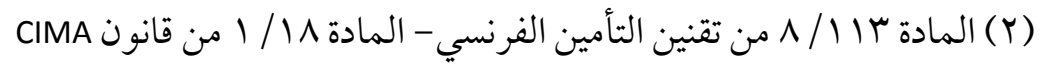

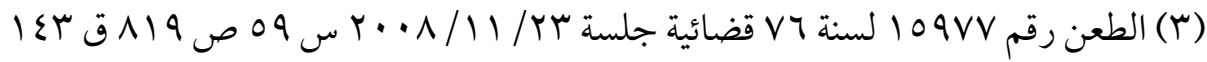


أن توقع عليه في هذه الحالة ، ومع ذلك فيرى البعض إمكان القياس على الأحكام القانونية

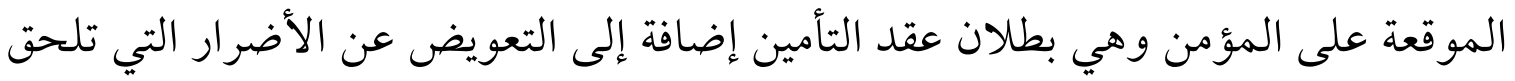

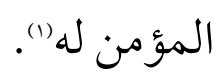

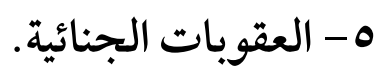

يمكن أن يتم تجاوز تلك العقوبات المدنية السابقة وذلك بتوقيع عقوبة جنائية كذلك إذا شكل فعل المؤمن له جريمة جنائية. فعندما يتصرف أحد طرفي العقد عمدا بييان كاذب ومتعمد من أجل تجنب التزاماته

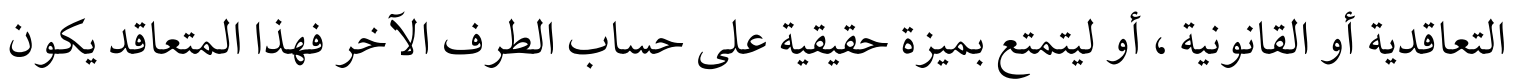

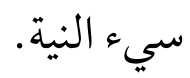
هذا الفعل الذى يرتكبه المؤمن له يكون جريمة النصب في التأمين ، التي تعتبر من الجرائم

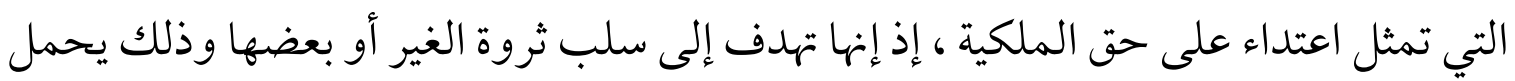
المجني على تسليمه ماله بتأثير تلك الأساليب الاحتيالية .

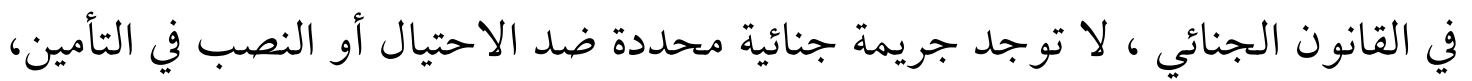
ولذا فإن جريمة النصب في التأمين تخضع لنص المادة بr؟ب من قانون العقوبات التي تحكم

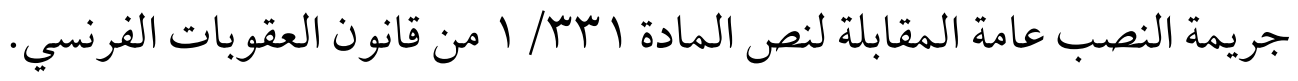

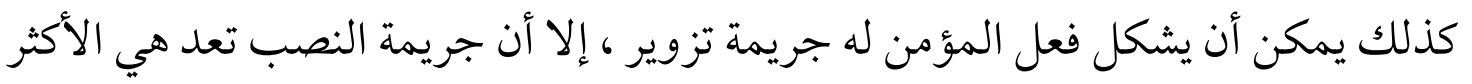

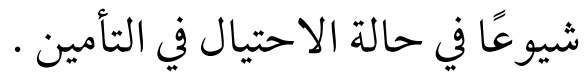
في جريمة النصب في التأمين لابد للمؤمن له من استعمال وسيلة من وسائل الاحتيال

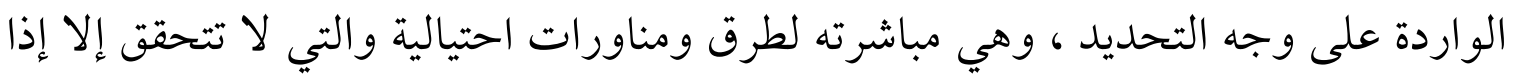
كانت مدعمة بمظاهر خارجية أو أعمال مادية يستعين بها المؤمن له لإقناع شركة التأمين

(1) Henriette E. Kameni , op , cit ,p.102 
بصدق أقو اله التي أدلى بها ، لذلك فإن التدليس بالسكوت عمدا الذى يرتكبه المؤمن له لا يكون جريمة نصب جنائية حتى لو كان له من الأثر أن المؤمن ما كان ليبرم العقد لو علم بتلك بلك بلك الو اقعة أو هذه الملابسة ، وهذا السكوت لا يكون إلا تدليسا مدنيا يعاقب عليه ببطلان العقد كما سبق أن أوضحنا أما التدليس الجنائي فلابد من وجود نشاط إيجابي ، ولا يكفي مجرد الامتناع أو السكوت أو الكتمان المتعمد من جانب المؤمن له ه. ومن تطبيقات ذلك ما قضى به القضاء الفرنسي من توافر الطرق الاحتيالية في جريمة النصب في التأمين ، إذا تقدم المؤمن له بشكوى إلى الشرطة يدعى فيها كذبا تعرضه للسرقة ،

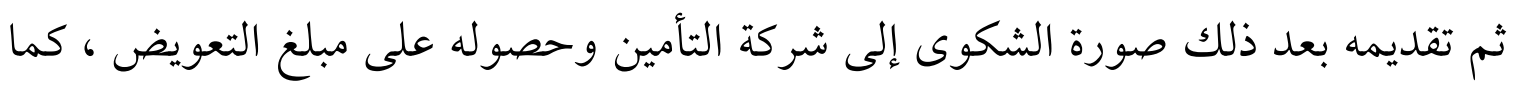
قضى بأن المؤمن الذى يتقدم إلى شركة التأمين ببيان كاذب عن المنقولات التي أتلفت ستع وقيمتها مستعينا في ذلك بشكوى تقدم بها إلى الشركة ذكر فيها ما هو مخالف لحقيقة فقده

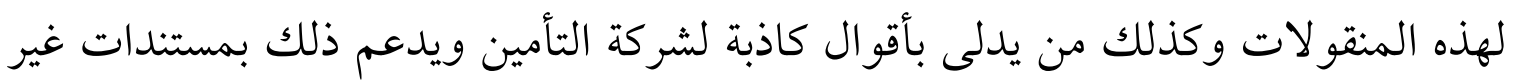
صحيحة ، إضافة إلى من يخفي سيارته المؤمن عليها ويتقدم ببلاغ إلى الشرطة يفيد سرقتها ، ويتمكن بهذه الوسيلة من الحصول على قيمتها من شركة التأمين" ، كذلك فإن إعلان الخسارة الزائف ، مصحوبًا بوثائق - مثل الفواتير المزيفة أو الشهادات المزيفة - لا تتوافق مع الو اقع يجب اعتباره مخططًا احتياليًا(). ويُعاقب المؤمن له في القانون المصري على الاحتيال في التأمين بالحبس وفقا لنص المادة

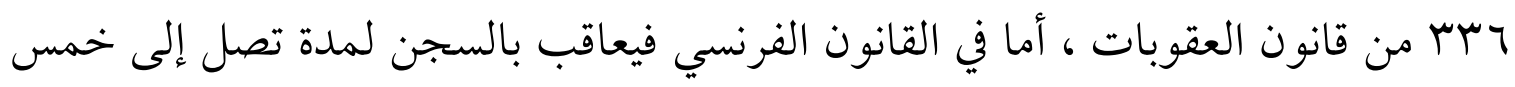

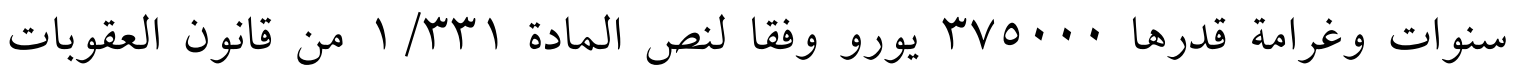

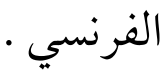

(1) cass.crim, 28 nov 1978, Gag.Pal,1979.somm.354 - Cass.crim, 13 mars 1989, Bull.crim, no.120 .gaz.pal 1989.1.437,Bordeaux, 9 nov. 1993,. j.c.p.1994.4.1420- cass.crim, 11oct 1989,,Bull. Crim,nov.352.

(2) cass. Crim.17 July 1991 no 90-87-454 
ثانيا -التوازن المالي بسبب التصريحات الجديدة للمؤمن له أتناء سريان عقد التأمين. في خلال سريان عقد التأمين يلتزم المؤمن له بواجب حسن النية في التصريح للمؤمن بكل ظروف جديدة قد تؤثر على عقد التأمين(1).

إدلاء المؤمن له بهذه البيانات يظهر حسن نيته ، كما أنه يسمح بتعديل التوازن الأساسي للعقد الذى تم إنشاؤه ، وذلك بتكييف هذا التوازن مع الوضع الجديد . و الظروف الجديدة قد تكون ظروفا تؤدى إلى تفاقم الخطر أو ظروفا تقلل من الخطر ، في كلا الحالتين فإن هذه الظروف تعطى لأطراف العقد الحق في الاختيار بين إنهاء عقد التأمين أو الإبقاء عليه مع زيادة أو نقصان تكلفة التأمين وفقا للظروف الجديدة ، وهذا الاختيار الأخير يكون في حال الإبقاء على العقد أما في حال وجود خلاف بين طرفي عقد التأمين فإنه لا مناص من إنهاء عقد التأمين. (أ)التوازن المالي في حال الخلاف بين الطرفين. عندما تنشأ الظروف الجديدة خلال فترة العقد فإن استمرارية العقد قد لا تكون ممكنة في الغالب خاصة عندما تؤثر بشكل كبير على موافقة شركة التأمين. فالظروف الجديدة إذا كانت موجودة من البداية قد تؤثر على قرار شركة التأمين والتي غالبا لم تكن لتقبل تغطية المخاطر منذ البداية أو كانت ستقبل ولكن في مقابل قسط أعلى من المتفق عليه . لذلك فإن هناك احتمال كبير في إنهاء عقد التأمين خاصة عندما لا يكون لدى الطرفين الرغبة في مواصلة العلاقة التعاقدية في أعقاب ظهور الظروف الجديدة . وحتى لو كان لدى أحد الأطراف النية في الإبقاء على العقد فإن هذه النية قد لا يقابلها رغبة

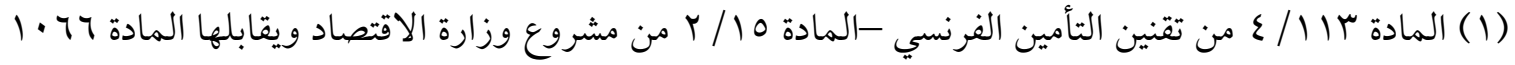

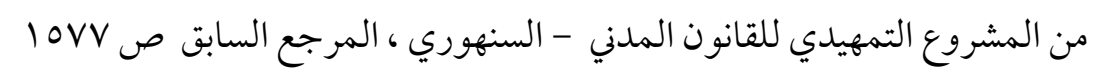


لدى الطرف الآخر في الاستمرار في العقد خاصة إذا كان هناك خفضا أو زيادة في تكلفة

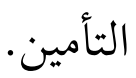

وهذا الإنهاء الذى قد يختاره الطرفان ليس إنهاء للعقد بسبب الخلل الكبير في التوازن

المالي كما هو الحال في حال بطلان العقد ، إنما هذا الإتهاء بسبب خلل معتدل في التوازن المالي.

وسوف نتعرض لبعض من صور الظروف الجديدة على النحو التالي: 1-التوازن في حال إعلان الظروف التي تؤدى إلى تشويه أو اختفاء الخطر.

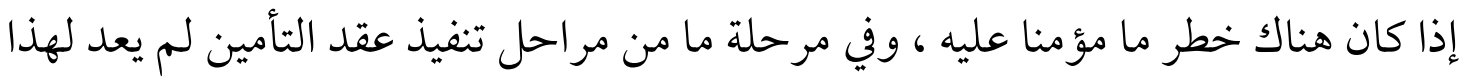
الخطر وجودا أو كان موجودا ولكن بصورة مشوهة وذلك بسبب حدوث تغير في الأوضاع المرتبطة بهذا الخطر ؛ كتغيير الشخص إقامته ، أو تغيير الحالة الاجتماعية ، أو تغيير في المهنة

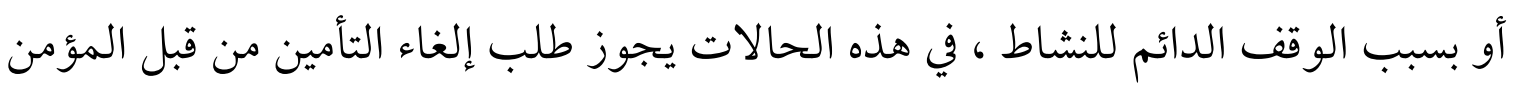
أو المؤمن له")؛ وذلك لأن عقد التأمين يغطى المخاطر المرتبطة بالوضع السابق والتي أصبحت غير موجودة بالوضع الجديد . كذلك قد يكون هناك تغير كبير في الخطر يؤدى إلى اختفائه ؛ مثل فقدان المؤمن له للممتلكات المؤمن عليها ، في هذه الحالة فقط يتم إنهاء العقد تلقائيا . وفقا للقانون الفرنسي ('فإنه يسمح بإنهاء العقد إذا اختار أحد طرفي العقد الإنهاء خلال ثلاثة

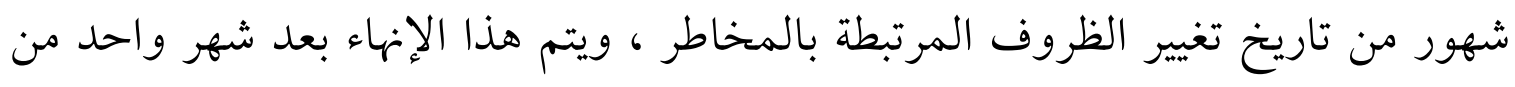

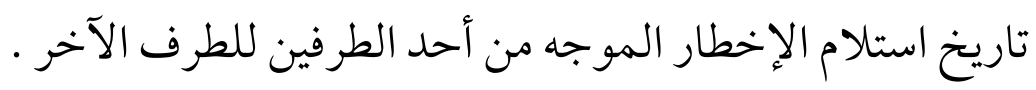

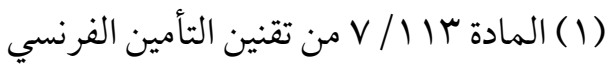

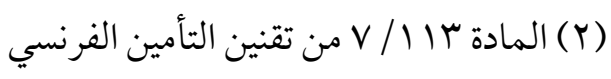


في هذه الحالة يجب على شركة التأمين أن تظهر حسن نيتها باحتفاظها فقط بالأقساط عن الفترة التي قامت بتغطيتها بالفعل ، أما الفترة غير المشمولة بالضمان والتي تبدأ من تاريخ الإنهاء فيجب عليها إعادة الأقساط المعادلة لهذه الفترة ؛ وذلك بحكم غياب الضمان و الخدمة عن هذه الفترة (1). في هذه الحالة يوجد توازن مالي كبير ؛ لأنه في تلك اللحظة التي يقوم فيها أطراف عقد التأمين بتسوية حساباتهم فيبقى مع كل طرف الجزء الذى يعنيه من القسط ، حيث يعود للمؤمن له قسط التأمين عن الفترة المقبلة بسبب براءة ذمته من هذا الالتزام بسبب إنهاء العقد ، ويبقى للمؤمن قسط التأمين عن الفترة الماضية المغطاة بالضمان. ץ-التوازن في حال إعلان الظروف التي تؤدى إلى تفاقم الخطر أو تقليل الخطر. في حال إعلان المؤمن له عما يستجد من ظروف يكون من شأنه تفاقم الخطر سواء بزيادة فرص وقوعه أو بزيادة درجة جسامته مما قد يترتب على وقوعه من أضرر ، فيكون الأمر متروكا لشركة التأمين لإنهاء العقد بعد زيادة المخاطر أو اختيار الإبقاء على العقد والمحافظة على الرابطة التعاقدية دون تغيير وذلك إذا رأت شركة التأمين أن التفاقم في حده الأدنى (()كما يمكن لشركة التأمين اختيار الإبقاء على العقد بالاتفاق مع المؤمن له مع زيادة أقساط التأمين. من ناحية أخرى في حال الحد من المخاطر فإنه يحق للشخص المؤمن له حق إنهاء العقد في حال عدم قبول شركة التأمين تخفيض قسط التأمين ؛ وذلك حتى لا يظل المؤمن له ضحية لمؤمن

Y. Lambert-Faivre,1998, op, cit , p.325,no 325 - (1 Yحمد حسام لطفي المرجع السابق ص و (1) (Y) المادة سا | / ع من تقنين التأمين الفرنسي- يقابلها المادة 0 / / من قانون CIMA - السنهوري ، المرجع السابق ص ع • • 17 ف ع

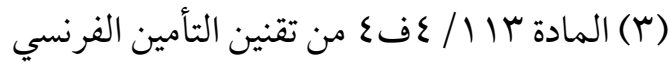


في جميع الأحوال فإن الإنهاء يحدث عندما لا يتفق أطراف العقد على الاستمرارية

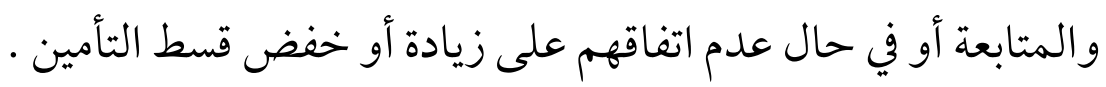
بمجرد انتهاء العقد يكون هناك توازن مالي بين الأطراف المتعاقدة"ويحتفظ كل واحد منهم بما يتمى له في المستقبل : المؤمن يجب أن يعيد القسط عن المدة التي لا لا يغطيها"()و المؤمن له سوف يقم بتحويل المخاطر إلى شركة تأمين أخرى إذا أراد ذلك . (ب) اختيار الإبقاء على العقد مع زيادة قسط التأمين.

قد يتفق طرفا عقد التأمين على الإبقاء على العقد مع إحداث تغييرات في تكلفة التأمين وفقا

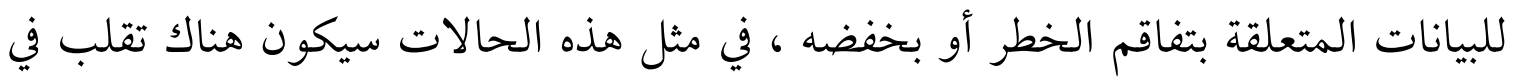

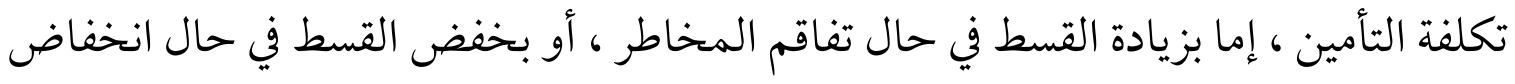
المخاطر ، ومن هنا يأتي إعادة التوازن المالي لعقد التأمين المشوه بالظروف الجديدة . فعندما يعلن المؤمن له بحسن نية للمؤمن عن حدوث الظروف الجديدة الني تؤدى إلى

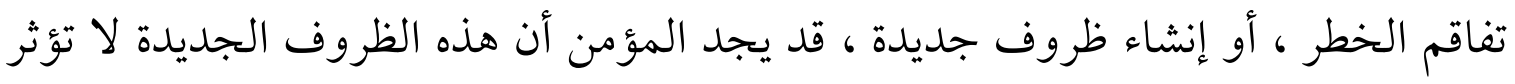
على قبوله لعملية التأمين نفسها وأن زيادته لقسط التأمين كفيلة بأن تعيد التوازن لحساباته ، في هذه الحالة إعادة التوازن المالي للعقد تكون صالحة للمستقبل فقط ، ويتم حسابها وفقا للإعلان الجديد الصادر من شركة التأمين والتي يجب عليها أن تستخدم هذا الحق بمجرد إدر اكها لهذه الظروف الجديدة أو على الأقل عندما تقرر مو اصلة علاقتها التعاقدية من خلال

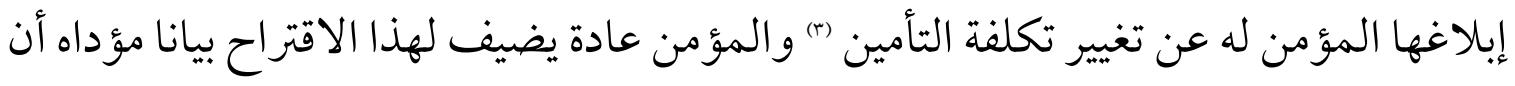

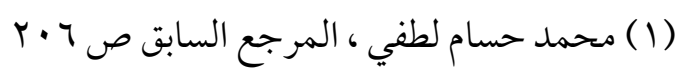
(Y) في كل مرة يتم فيها إنهاء الخدمة ، يتم استرداد تكلفة التأمين للفترة غير المشمولة. ويستند ذلك إلى مبدأ تقسيم 
عدم استجابة المؤمن له لهذه الزيادة تجعل العقد منتهيا") والحل هنا يعتمد على موافقة المؤمن له(ب(الذى يجب عليه الموافقة كتابة لتعديل العقد ، وفي حال الموافقة فإن القسط الجديد يتكون من القسط التي تم الاتفاق عليها في بداية التعاقد مضافا اليها مبلغ إضافي نظير المخاطر المضافة وهو ما يطلق عليه الرسم الإضافي ، ويكون هذا الاتفاق في ملحق يرفق بالعقد الذى تم إبرامه سابقاب(). في هذه الحالة فإن إعلان المؤمن له عن تفاقم الخطر أو المخاطر الجديدة عمل على إعادة ضبط الأرضية الوسطى للعقد بأبعاده المالية وصحح التوازن المالي للعقد. تخفيض تكلفة التأمين : n - n عند وجود ظروف جديدة تقلل من الخطر أثناء سريان عقد التأمين فإن هذه الظروف الجديدة يجب أن يقابلها خفضا في تكلفة التأمين ؛ لذلك من مصلحة المؤمن له أن يعلن المؤمن بهذه الظروف ويطلب منه خفض تكلفة التأمين ، ولا يمكن للمؤمن له المطالبة بهذا التخفيض إلا إذا كان تخفيض الخطر حقيقيا ، فالتخفيض يكون مستبعدا بدون أي تأثير مالي. يجب على شركة التأمين إظهار الحسن نيتها المو افقة على تخفيض قسط التأمين (8) في حال

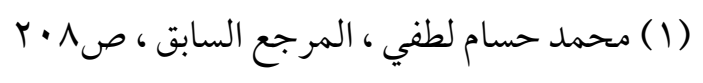

(Y) ويلتزم المؤمن له بتعويض المؤمن في حال التعسف في رفض الزيادة المقترحة من المؤمن ـ محمد حسام لطفي

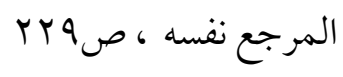

(r) فعلى سبيل المثال في التأمين على السيارات إذا كان المؤمن له يحب أن يضيف مقطورة لأسباب مهنية فعليه إبلاغ المؤمن بالوضع الجديد وبالتالي عندما يوافق على الإبقاء على العقد سيكون هناك زيادة في قسط

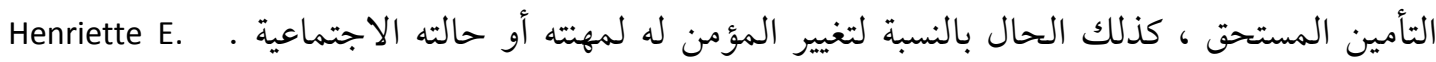

(ع) و المؤمن في حال الرفض يدفع تعويض للمؤمن له إذا اتسم رفضه للتخفيض بالتعسف. محمد حسام لطفي،

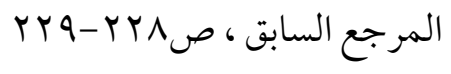


قبول طرفي العقد الإبقاء على العقد فإن هذا الوضع يفيد المؤمن له ويتم تخفيض قسط

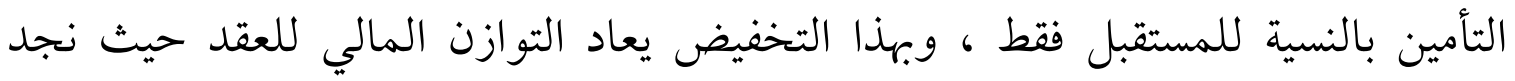

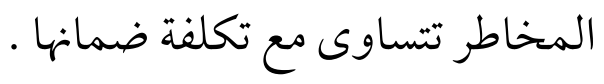
بشكل عام فإن الإعلان عن الظروف التي تؤدى إلى تفاقم المخاطر أو تخفيضها تؤدى إلى تقلب تكلفة التأمين من أجل تكييف عقد التأمين الذى تم إبرامه مسبقا وفقا للوضع الحالي وبالتالي تساهم هذه التغير ات في التكلفة في إعادة التوازن المالي للعقد .

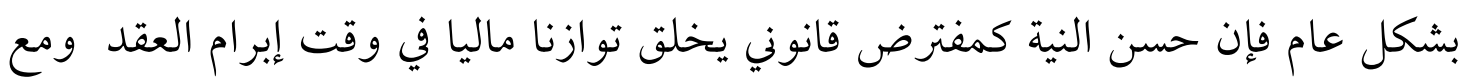
ذلك فإن هذا التوازن الذى أوجده الطرفان توازن هش ؛ لأنه كلما قام دليل على سوء نية أحد بـ ليد المتعاقدين فإن هذا التوازن يختل بسبب بطلان العقد المصحوب بدفع التعويضات

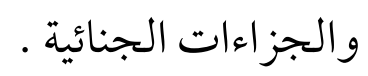

إضافة إلى ذلك فإن هناك طبيعة غير مستقرة للتوازن الأساسي للعقد ينتج أثناء تنفيذ وسريان العقد وذلك في حال تحقق ظروف جديدة لم تكن موجودة وقت العقد ، ويتم إعادة تكييف هذا التوازن في كل مرة يتم فيها الإعلان عن حدوث التغيرات غير المتوقعة للخطر ، فيسمح هذا الإعلان إما بإحداث توازن مالي يتتج عن إنهاء العقد المذكور أو الإبقاء على تهي

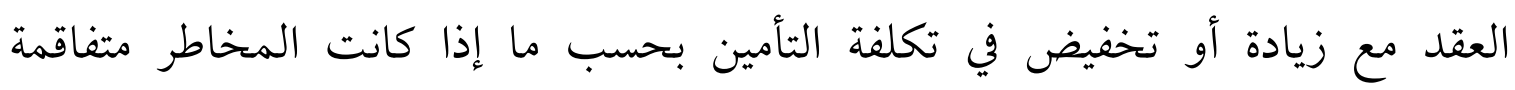

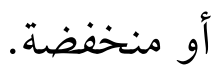

\section{المطلب الثاني \\ الخطأ المرتكب بحسن نية والتوازن التمالي في عقد التأمين}

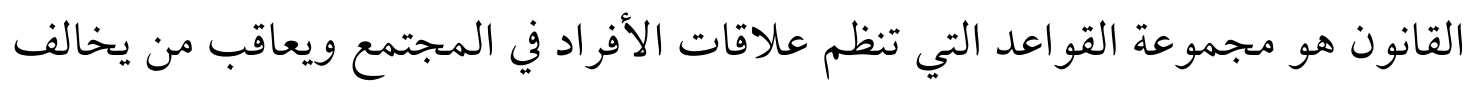
هذه القو اعد وفقا لشدة المخالفة التي يرتكبها ووفقا لفرع القانون الذى يخالفه. في السياق الجنائي هناك عقوبات جنائية تبدأ بالغر امة وتنتهي بالإعدام ، ويكون تطبيق هذه

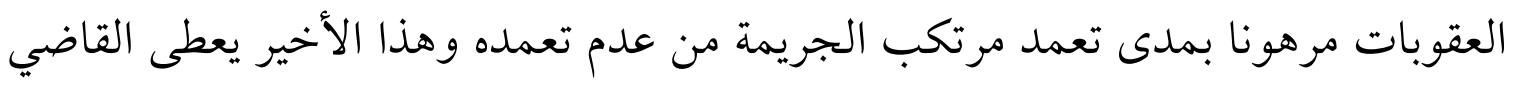


الحق في تطبيق العقاب المخفف.

كذلك هو الحال في القانون المدني فإن العقوبات تكون صارمة في حال قصد المخالفة وسوء نية المخالف ، وتكون العقوبات مخففة في حال حسن نية المخالف.

قانون التأمين ليس استثناء من هذا المبدأ العام الساري على كل القوانين المختلفة فهو يأخذ في الاعتبار الفعل المتعمد أو غير المتعمد فنجد كما رأينا سابقا أن الإدلاء ببيانات كاذبة يعاقب عليه بشدة ؛ وذلك من أجل استعادة حقوق الخصوم ، و المحافظة على سمعة قطاع التأمين ، وردع مرتكبي الفعل ، أما الإدلاء ببيان كاذب عن غير قصد فله عقوبات خفيفة تصل إلى حد فقدان الطابع العقابي ؛ هذا التخفيف من العقاب أتى من حسن النية التي تعتبر أداة أخلاقية لقانون التأمين ، ووسيلة للمحافظة على البيئة المالية الصحيحة بين المتعاقدين ·

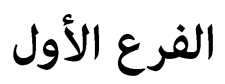

تصحيح التوازن المالي في حالة الكشف عن خطأ غير مقصود تم اكتشافه قبل المطالبة

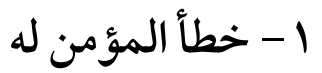

في حال إدلاء أحد طرفي عقد التأمين بييانات كاذبة غير مقصودة تحدث قبل وقوع الكارثة فإن العقاب الذى قرره المشرع جاء في شكل تدابير وليست عقوبات ، هذه التدابير هدفها الأساسي هو استعادة التوازن الأساسي الذى تم إنشاؤه عند تكوين العقد. فالإغفال أو التحريف غير المتعمد من جانب المؤمن له لا يستتبع بطلان عقد التأمين ، وإنما يتم الحفاظ على عقد التأمين مع زيادة تكلفة التأمين التي تتناسب مع الظروف التي لم يكن يعرفها المؤمن أو يتم إنهاء العقد المذكور : (أ) الإبقاء على العقد

عندما يكتشف وجود إعلان خاطئ من المؤمن له بحسن نية قبل تحقق الكارثة فيحق لشركة التأمين الإبقاء على العقد مع زيادة الأقساط المقبولة من المؤمن له . 
في هذه الحالة يتعين على شركة التأمين تحديد مبلغ القسط الإضافي المر اد إضافته إلى مبلغ القسط الأولى ، كما يجب موافقة المؤمن له على هذه الزيادة ، وعلى أن يتم ذكر القسط الجديد في اتفاقية جديدة كملحق للعقد وتوقع من قبل طرفي العقد.

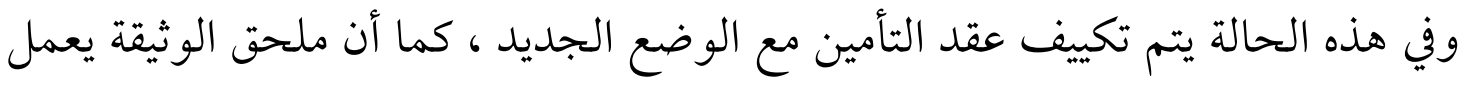
كوسيلة لإثبات التغيير في قيمة قسط التأمين الذى اقترحه المؤمن وقبله المؤمن له . ومع ذلك فإن الاتفاق المكتوب بزيادة القسط ليس هو الوسيلة الوحيدة لإثبات زيادة القسط إنما يمكن إثبات هذا التغيير عن طريق التنفيذ لهذه الزيادة من قبل المؤمن له دون

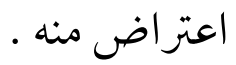
هذا ولا تسرى الزيادة في حق المؤمن له إلا من تاريخ قبول المؤمن له لها ؛ وهذا يعنى أن القسط المضاف يكون أثره بالنسبة للمستقبل فقط ولا ينطبق على الماضي حيث لا يمكن

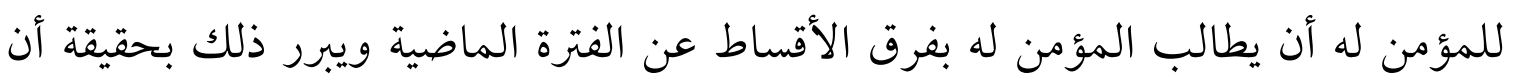

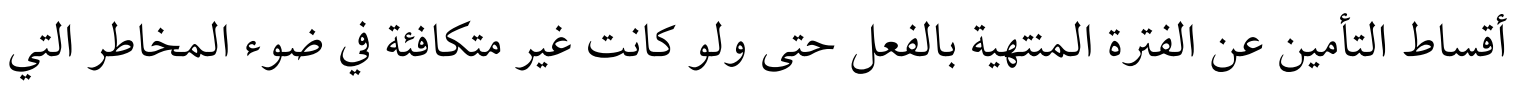
يتعرض لها المؤمن يتم الحصول عليها الآن وذلك لأن الحادث لم يحدث خلال الفترة السابقة ويجب التركيز فقط على المستقبل (1). (ب) (بإنهاء عقد التأمين قد تختار شركة التأمين إنهاء العقد في حال اكتشاف البيانات الكاذبة غير المقصودة من

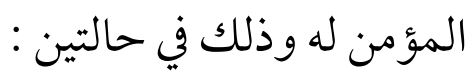
الحالة الأولى عندما تجد شركة التأمين انعدام الوسيلة التي تؤدى إلى إعادة التوازن

(1) يستفيد كل من الطرفين المتعاقدين من الوضع السائد: دفع المؤمن له تكلفة تأمين أقل مما هو مطلوب عادة ،

$$
\text { ولم يضطر المؤمن لتعويضه لأن الخطر لم يتحقق بعد. }
$$


لعلاقتها التعاقدية مع المؤمن له ؛ كما لو كانت الحقيقة المجهولة من الأهمية بمكان بحيث لو كانت تعلم بها مسبقا ما تعاقدت أصلا ، وفي هذه الحالة يتم الإنهاء مباشرة من قبل شركة التأمين دون مفاوضات على زيادة قسط التأمين · أما الحالة الثانية فيتم الإنهاء بعد انتهاء المفاوضات الودية بين طرفي عقد التأمين دون الاتفاق على زيادة قسط التأمين بسبب رفض المؤمن له للزيادة المقترحة من المؤمن ، وفي هذه الحالة يمكن للمؤمن الحصول على تعويض عن الرفض غير المبرر من المؤمن له للزيادة العادلة المقتر حة من قبل المؤمن · وقد درج العمل على أنه في جميع الحالات يتم الإنهاء من خلال إرسال المؤمن للمؤمن له خطابا مسجلا بعلم الوصول يعلمه فيه برغبته في إنهاء العقد ، وعلى أن يكون الإنهاء ساري المفعول بفوات عشرة أيام تبدأ من اليوم التالي لإرسال الخطاب إلى المؤمن له ، وتعتبر فترة العشرة أيام فترة واقية الهدف منها منح المؤمن له وقتا للعثور على شركة تأمين أخرى تقوم بتغطية مخاطرة ؛ وذلك لأن عقود التأمين تتطلب وقتا لإبر امها . وبمجرد انتهاء فترة العشرة أيام يصبح العقد منتهيا ، ويكون للإنهاء جميع آثاره ، فيتم الاحتفاظ بكل آثار العقد عن الفترة الماضية ، أما بخصوص المستقبل فبحكم أن عقد التأمين لم يعد ساريا ولم يعد يغطى مخاطر المؤمن له لذلك يجب على المؤمن أن يرد للمؤمن له قسط التأمين المعجل عن الفترة غير المشمولة بالضمان.

\section{r - r خأ المؤمن ( شر كة التأمين )}

إن سلوك المؤمن مثله مثل سلوك المؤمن له سيكون له انعكاسات على التدابير المطبقة في حال اكتشاف خطأ ارتكبه قبل وقوع الكارثة . فإذا أخطأ المؤمن بسوء نية فسوف يعاقب بشدة على هذا السلوك المتعمد ، على العكس من ذلك إذا كان خطأه بحسن نية فإن هذا الخطأ سيعالج بتدابير تهدف إلى إصلاح الضرر فقط. 
لم يذكر المشرع صراحة التدابير المطبقة على المؤمن في حال ارتكابه أخطاء غير مقصودة ومع ذلك فإن هناك عدم قابلية لتطبيق عقوبات صارمة على شركات التأمين ؛ لذلك فإن العقاب سيكون في شكل تدابير تهدف لتصحيح الأخطاء المرتكبة بحسن نية . فقي قانون الإشراف و الرقابة على التأمين في مصر تنص المادة · r منه (1)على أنه " يصدر بتسجيل الشركة والترخيص لها بمز اولة نشاطها قرار من رئيس مجلس إدارة الهيئة خلال شهر من تاريخ استيفاء شروط التسجيل وينشر هذا القرار في الوقائع المصرية على نفقة الشركة وتقوم الهيئة بتسجيل الشركة في السجل المعد لذلك. ولا يجوز للشركة أن تبدأ في مزاولة أعمالها إلا بعد تسجيلها والترخيص لها بمزاولة النشاط، كما لا يجوز لها أن تزاول أي فرع من فروع التأمين غير الفروع المرخص لها بها. ويقع باطلا كل عقد تأمين يبرم على خلاف ما تقدم ، ولا يحتج بهذا البطلان على المؤمن

$$
\text { لهم و المستفيدين إلا إذا ثبت سوء نيتهم". }
$$

كما تنص المادة VV من ذات القانون على أنه " يعاقب بالحبس وبغر امة لا تقل عن خمسة الاف جنيه و لا تجاوز خمسين ألف جنيه أو بإحدى هاتين العقوبتين: 1 -كل من زاول أي فرع من فروع التأمين أو إعادة التأمين في مصر دون ترخيص. Y-كل من مثل هيئات أو شركات تأمين أجنبية أو توسط لديها دون ترخيص بذلك من الهيئة . ץ-كل من امتنع عن تقديم الدفاتر والمستندات لمندوبي الهيئة الذين لهم حق الاطلاع عليها وذلك فضلاً عن الحكم بتقديمها ، وكذلك في حالة التأخير في تقديم البيانات الواجب تقديمها في المواعيد المحددة بهذا القانون و لائحته التنفيذية ، ويجوز الحكم في هاتين الحالتين بغرامة تهديدية يعين الحكم مقدارها عن كل يوم امتناع أو تأخير بحد أقصى 


$$
\text { خمسين جنيهًا عن اليوم الواحد . }
$$

ع - كل من أقر أو أخفي متعمداً بقصد الغش في البيانات أو المحاضر أو في الأوراق الأخرى

$$
\text { التي تقدم الى الهيئة أو التي تصل الى علم الجمهور. }
$$

0-كل من أفشى أسراراً حصل عليها عن طريق ممارسته لعمله طبقَّ لهذا القانون "

كما تنص المادة VA من ذات القانون على أنه " ا-يعاقب كل من خالف التعريفات

أو الأسعار أو الشروط أو النماذج المبلغة الى الهيئة والمعتمدة منها وفقًَ لأحكام المادة

( 1 ) من هذا القانون بغرامة لا تقل عن مائة جنيه و لا تجاوز ألف جنيه .

ويحكم على شركة التأمين المخالفة للتعريفات أو الأسعار أو الشروط أو النماذج المشار

اليها بغر امة مالية توازى ضعف رسوم التأمين بالنسبة للحالة موضوع المخالفة وبحد أدنى ألف جنيه وحد اقصى مائة ألف جنيه بالنسبة لكل حالة ، ويتم تحريك الدعوى الجنائية عن هذه المخالفات بناء على طلب كتابي من الهيئة ، ويجوز للهيئة في أي وقت حتى صدور حكم بات في الدعوى الجنائية أن تتصالح مع الشركة المخالفة مقابل سدادها كل أو بعض الغرامة المالية المشار اليها ويترتب على هذا التصالح انقضاء الدعوى الجنائية". كما تنص المادة V9 من ذات القانون على أنه " مع عدم الإخلال بأية عقوبة أشد ينص عليها قانون العقوبات أو أي قانون آخر، يعاقب بالحبس مدة لا تقل عن ستة أشهر أو بغرامة لا تقل عن خمسة ألاف جنيه ولا تجاوز خمسين ألف جنيه كل من توسط في مصر في عقد عمليات تأمين أو إعادة تأمين ، وكذلك كل من باشر مهنة الخبراء الاكتواريين أو خبراء التأمين الاستشاريين أو خبراء المعاينة وتقدير الأضرار دون أن يكون مقيداً في السجلات الخاصة المنصوص عليها في هذا القانون، وتسرى ذات العقوبة على المسئولين في شركات

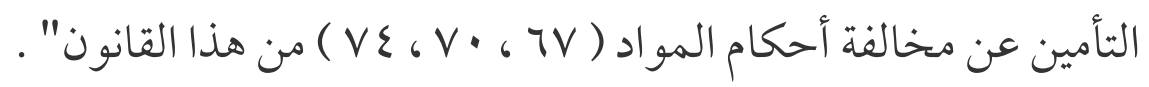
يتضح لنا من قراءتنا لنصوص المواد السابقة تشدد المشرع في العقوبات التي تقع على 
شركات التأمين في حال ارتكابها للأفعال الخاطئة المتعلقة بمباشرة ومزاولة عملية التأمين والأسعار والتعريفات والنماذج وكذلك الحال في حال مباشرة خبراء التأمين دون القيد في السجلات الخاصة بذلك ، ولم يفرق المشرع في العقوبات المفروضة على شركات التأمين بين حسن أو سوء نية شركة التأمين ، فهي تطبق على كل شركة تأمين سواء كانت حسنة النية أو سيئة النية ؛ ويرجع السبب في تشدد المشرع في عقابه إلى الطابع المهني والاحترافي لشركة التأمين و التي يجب عليها ألا ترتكب هذه الأفعال . هذا وقد خول المشرع للهيئة العامة للإشراف والرقابة على التأمين الحق في التصالح مع شركات التأمين بعد سداد كل أو بعض الغر امة المقررة . كما أن شركة التأمين تلتزم بكل ضرر تسببه للمؤمن له ، سواء كان هذا الضرر صادرا من شركة التأمين أو من موظفيها ومندوبيها سواء عن عمد أو إهمال وذلك وفقا للمواد سا7 مدنى مصري و المادة IV / I مدنى التي تحدد مسئولية المتبوع عن أعمال تابعه(1)فتلتزم شركة التأمين بإصلاح أخطائها وأيضا أخطاء موظفيها وتابعيها. في الحالات الأخرى غير المذكورة يجب على شركة التأمين إبلاغ المؤمن له بالوقائع التي لم يكشف عنها مع طلبها تعديل العقد وفقا للوقائع المكشوفة ، مع مراعاة - إذا لزم الأمر تعويض المؤمن له عن الأضرار التي سببتها له شركة التأمين من جراء عدم كشفها عن بعض

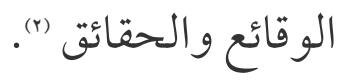
وسوف نتعرض لمسألة الخطأ في سن المؤمن عليه في التأمين على الحياه إذا سواء وقع الخطأ من المؤمن له أو من شركة التأمين ·

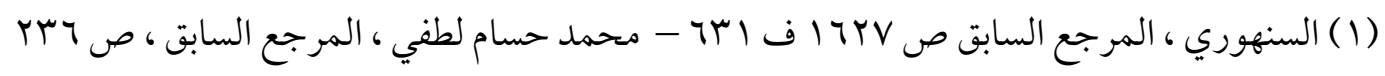
(2) Henriette E. Kameni, op , cit ,p.122 


\section{الخطأ في سن المؤمن عليه في التأمين على الحياه: - (المياه}

قرر المشرع نصا خاصا بخصوص حالات الغلط أو الخطأ في سن المؤمن على لى سلى حياته")حيث جعل بطلان عقد التأمين في حالة وحيدة فقط هي الحالة التي يكون فيها السن الحقيقي للمؤمن له خارج الشريحة السنية التي يدفع عنها المؤمن له القسط ("). في غير هذه الحالة فإن الخطأ في سن المؤمن له يستبع تصحيح هذا الخطأ دون إبطال العقد(()فإذا كانت سن المؤمن له لا تجاوز الحد المعين الذى نصت عليه تعريفة التأمين ففي هذه الحالة يكون عقد التأمين صحيحا ولا يجوز إبطاله وذلك سواء أكان المؤمن له حسن النية أو سيء النية عندما قرر لنفسه سنا غير السن الحقيقية.

فإذا كان قسط التأمين المتفق عليه أقل من قيمة القسط الذى كان ينبغي على المؤمن دفعه

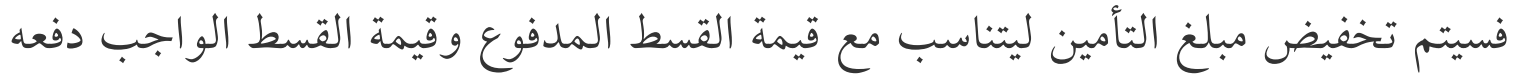
على أساس السن الحقيقية (4). أما إذا كان قسط التأمين المتفق عليه أعلى من قيمة القسط المستحق فيجب على شركة التأمين تخفيض أقساط التأمين التالية لتتناسب مع السن الحقيقية للمؤمن له كما يجب عليها لهيها رد الزيادة في القسط الذى حصلت عليه دون فو ائد هذه الزيادة". إن المبدأ هو استمرارية العقد ، والهدف من التدابير المتخذة بخصوص قسط التأمين هو

$$
\begin{aligned}
& \text { (1) المادة ع VT مدنى مصري - المادة Y Y / / Y من تقنين التأمين الفرنسي - المادة • A / I من قانون CIMA }
\end{aligned}
$$

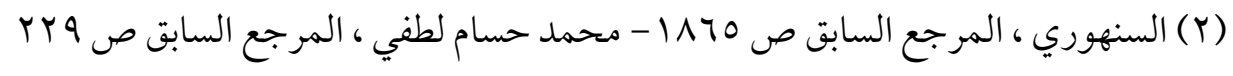

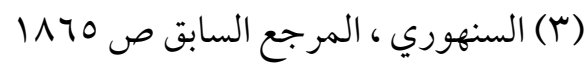

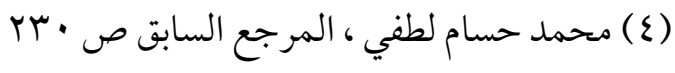

$$
\begin{aligned}
& \text { (0) المادة ع Y r مدنى مصري }
\end{aligned}
$$


استعادة التوازن المالي للعقد") الذى اختل بسبب الخطأ في سن المؤمن له وبالتالي فإن البطلان هو الاستثناء الذى يحدث فقط في الحالة التي يتجاوز فيها السن الفعلي للمؤمن له الحدود الموضوعة من قبل المؤمن. - المن. كذلك الحال بخصوص الأخطاء المادية وغيرها من الأخطاء البسيطة فإن هذه الأخطاء يتم تصويبها مع استمرارية العقد المرهون بإعادة التوازن المالي .

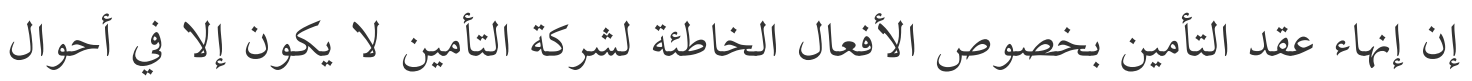

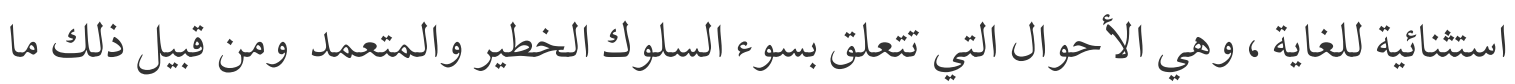
ورد بالمادة سr/ 9 من قانون CIMA التي تقرر عقوبة السجن والغرامة لمن يرتكب عن علم الإعلان عن عمليات محاكاة الاشتراكات غير الموجودة ، والإعلانات المضللة وغيرها من

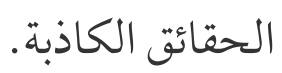

المادة تتحدث عن ارتكاب الأفعال الخاطئة عن علم ومعرفة ، وهذا معناه التعمد من قبل

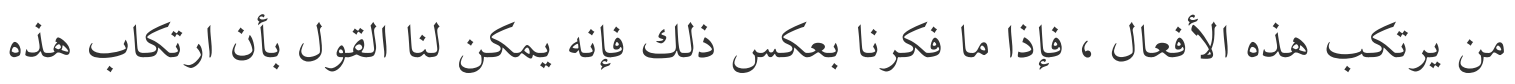

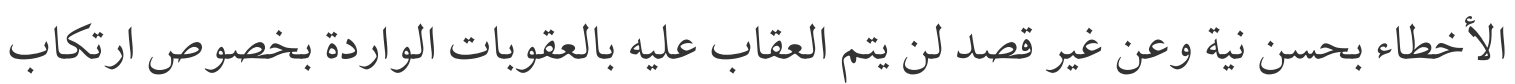

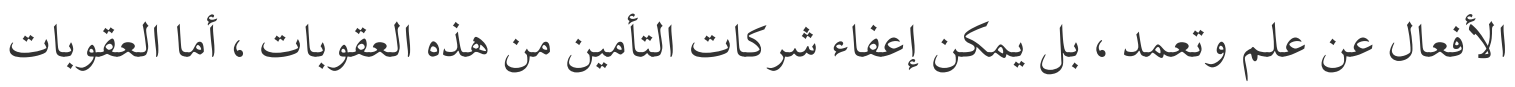

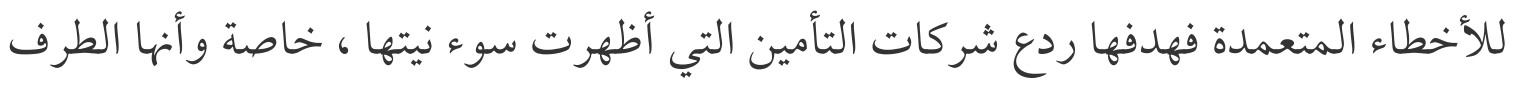
المهني المحترف في عملية التأمين.

\section{التدابير المقررة لحماية المؤمن له بحسن نية :}

إضافة إلى إصلاح الخطأ الذى يرتكبه المؤمن بحسن نية هناك حالات لا يبالى فيها

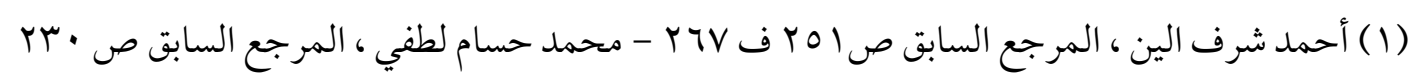


المشرع بحسن أو بسوء نية المؤمن ، وإنما كل ما يهمه هو حماية المؤمن له من بعض أخطاء المؤمن ومن هذا القبيل ما نصت عليه المادة · ب من قانون الإشراف والرقابة على التأمين على أنه " يصدر بتسجيل الشركة والترخيص لها بمزاولة نشاطها قرار من رئيس مجلس إدارة الهيئة خلال شهر من تاريخ استيفاء شروط التسجيل ، وينشر هذا القرار في الوقائع

المصرية على نفقة الشركة وتقوم الهيئة بتسجيل الشركة في السجل المعد لذلك". ولا يجوز للشركة أن تبدأ في مزاولة أعمالها إلا بعد تسجيلها والترخيص لها بمزاولة النشاط كما لا يجوز لها أن تزاول أي فرع من فروع التأمين غير الفروع المرخص لها بها. ويقع باطلا كل عقد تأمين يبرم على خلاف ما تقدم ، ولا يحتج بهذا البطلان على المؤمن لهم و المستفيدين إلا إذا ثبت سوء نيتهم." فالقانون يوجب على أي شركة تأمين قبل بدء عملياتها الحصول على الترخيص و الموافقات التي قررها ولا يسمح لها بالتعاقد مع الأشخاص المؤمن لهم إلا بعد الحصول

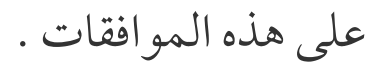

ومع ذلك عندما يبرم المؤمن عقد تأمين مع المؤمن له دون أن يحصل على ترخيص مزاولة نشاط التأمين ، فإن العقد باطل من حيث المبدأ وذلك دون اخلال بالعقوبات الجنائية المنصوص عليها بالمادة VV من قانون الإشراف والرقابة على التأمين ، ومع ذلك عندما يكون المؤمن له حسن النية بحيث لم يكن يعلم بعدم حصول المؤمن على ترخيص مزاولة نشاط التأمين فإن هذا البطلان ينتج آثاره تجاه أي شخص فيما عدا المؤمن له أو المستفيد حسن النية ، فإن هذا البطلان غير قابل للتنفيذ عليه(1)؛ نتيجة لذلك تظل شركة التأمين ملتزمة

(1) Henriette E. Kameni, op , cit ,p.126 ( الفقرة الاخيرة من نص المادة VV قانون الإشراف والرقابة على

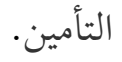


بجميع الالتزامات التي يفرضها عليها عقد التأمين ، وبالتالي تعويض المستفيد في حال وقوع الحادث ، كما يظل المؤمن له مسئولا بنفس القدر عن دفع قسط التأمين وعن الوفاء بأي التزام آخر وارد بالعقد . مات.

وبذلك يكون عدم إمكانية البطلان مأخوذ لصالح المؤمن له حسن النية ؛ لحمايته من

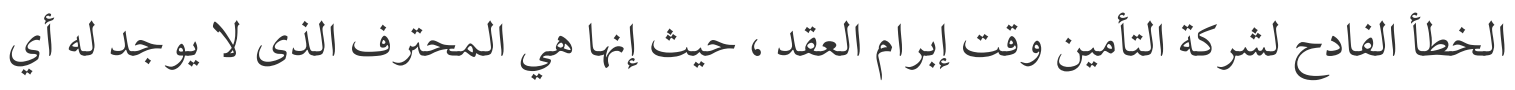
مبرر لنفهم منه لما يتصرف على هذا النحو ، ولذلك فالحماية هنا حصرية للمؤمن له فقط .

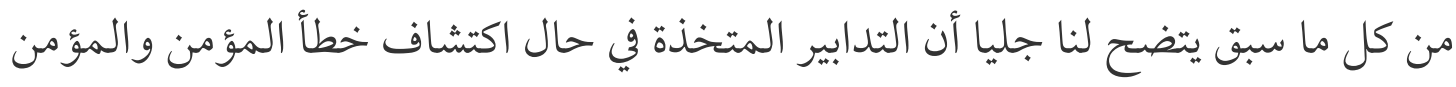
له قبل وقوع الكارثة لها دور كبير في تصحيح التوازن المالي للعقد باستثناء حالات قليلة يتم

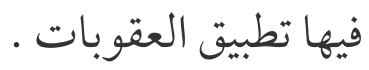

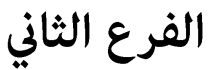

\section{استعادة التوازن المالي للعقد في حال اكتشاف خطأ غير مقصود بعد وقوع الكارثة}

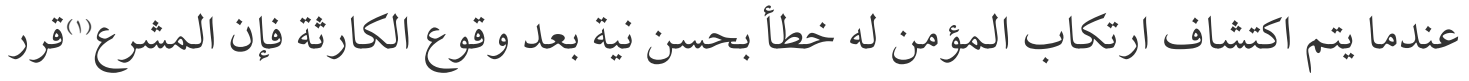

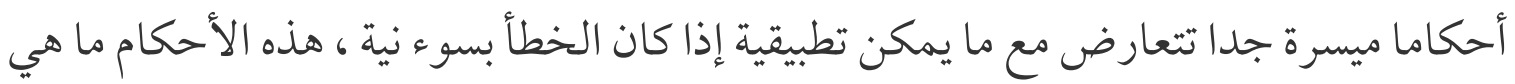
إلا تدابير هدفها استعادة الرصيد المالي للعقد وتتميز بالمرونة التي قد تصل إلى حد الإعفاء التام من العقاب وذلك من أجل احتفاظ شركة التأمين بعملائها .

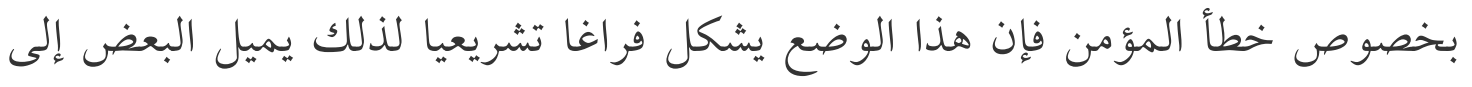

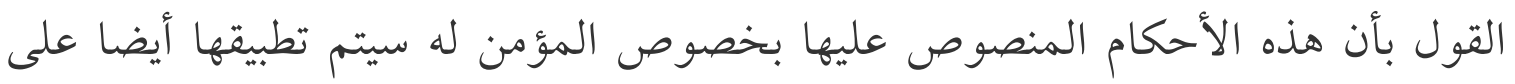
المؤمن) (1) (n)

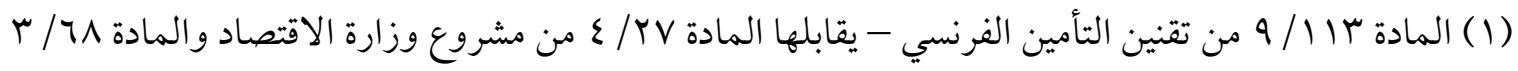

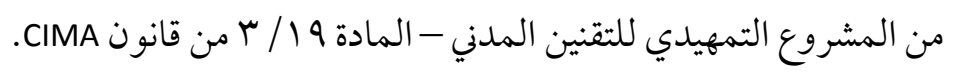

(2) Henriette E. Kameni, op , cit ,p.127 
هذه الأحكام المتعلقة بالعقوبات على المؤمن له تتميز بمرونتها ، حيث إنه إذا تم اكتشاف خطأ المؤمن له حسن النية - سواء كان الخطأ إغفالا أو ذكر بيانات كاذبة - وذلك بعد وقوع الكارثة فإن حكم القانون هنا هو تخفيض التعويض المستحق ليتناسب مع قسط التأمين الذى دفع بالفعل إلى معدل الأقساط التي كان يجب أدائها إذا كانت المخاطر قد أعلنت بصورة كاملة(1) وينطبق هذا الحكم حتى ولو لم يكن للإعلان الخاطيء أي تأثير على تحقق الخطر ((). إن دفع التعويض المخفض سيؤكد فكرة استعادة التوازن المالي المختل بسبب الخطأ

$$
\text { الذى ارتكبه المؤمن له بحسن النية. }
$$

كذلك يحق لشركة التأمين أخذ هذا الاكتشاف في الاعتبار وذلك لتعديل قسط التأمين إذا كانت ترغب في مواصلة علاقتها التعاقدية مع المؤمن له ، أما إذا كان من المستحيل مواصلة العلاقة التعاقدية فإن لها خيار إنهاء العقد (r).

وسوف نميز بخصوص الإعلانات الخاطئة في التأمين بين ثلاث حالات وهي : حالة التأمين الزائد ، حالة التأمين التراكمي ، وحالة التأمين الناقص ، ثم نبين في النهاية الدور الهام الذى يمكن أن تلعبه التسوية الودية كأحد وسائل دفع التعويضات للمؤمن له بدلا من اللجوء إلى القضاء.

\section{أو لا-التخفيض النسبي للتعويض المستحق على شر كة التأمين:}

من أجل تطبيق التخفيض النسبي لمبلغ التأمين ينبغي ألا يكون المؤمن له قد قدم تحريفا غير مقصود وفقط ، بل يجب أيضا أن يتم اكتشاف هذا التحريف بعد وقوع الكارثة ، بالإضافة

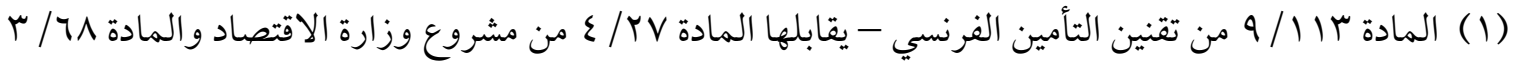

$$
\begin{aligned}
& \text { من المشروع التمهيدي للتقنين المدني - المادة } 9 \text { / / م من قانون CIMA. }
\end{aligned}
$$

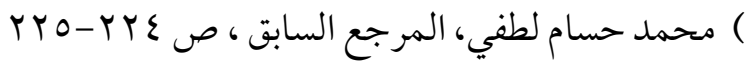

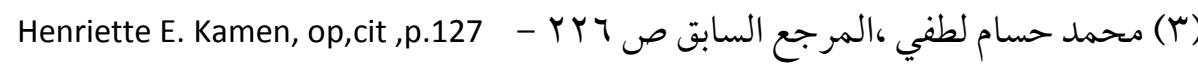


إلى ضرورة إظهار شركة التأمين لإرادتها في استخدام هذا الحق في التخفيض حيث لا يجوز للمحكمة أن تقضى بالتخفيض إلا إذا تمسك المؤمن صراحة بذلك (1). في هذه الحالة تقوم شركة التأمين بتخفيض التعويض بما يتناسب مع معدل الأقساط المدفوعة مقارنة بمعدل الأقساط التي كانت مستحقة لو كانت المخاطر المعلنة كاملة ودقيقة") - وهذه القاعدة تسمى قاعدة المكافأة النسبية() - ولا ينبغي الخلط بين هذه الآلية

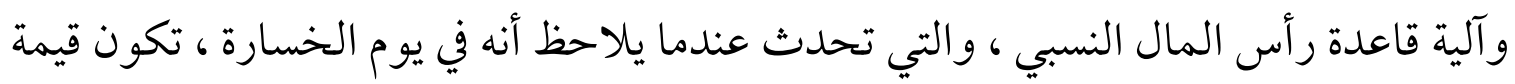
الممتلكات المؤمن عليها أكبر من القيمة التي تم التأمين عليها في البداية(3). وهذا التخفيض له ما يبرره حيث إن دقة المعلومات المقدمة من المؤمن له هي التي تشكل رأي المؤمن في تغطية المخاطر ، كما أنها هي أساس تسعير قسط التأمين وتحديد مبلغ التأمين وبالتالي عندما تحدث المخاطر فلا يجب تحميل شركة التأمين تعويضا يقابل المخاطر كاملة في حين أن المؤمن له لم يكن يدفع إلا قسطا لا يعادل القيمة الحقيقية لهذه المخاطر وبالتالي لا يجب تغطية المؤمن له إلا وفقا للقسط المدفوع. والصيغة الرياضية لهذه الحالة تكون على النحو التالي :

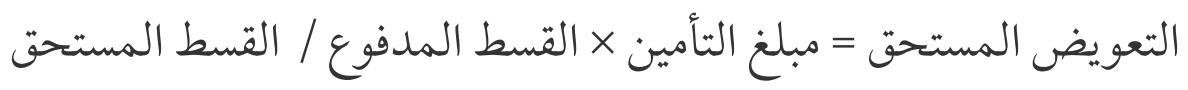
فعلى سبيل المثال إذا كان مبلغ التأمين المثفق عليه هو بـ . . ألف جنيه ، ومعدل الأقساط المدفوعة هو 10 ألف جنيه ومعدل الأقساط المستحقة الدفع هو · بألف جنيه فإن التعويض

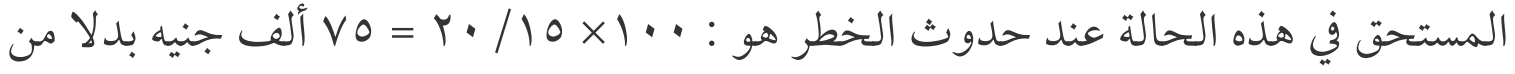

Henriette E. Kameni, op , cit ,p.128 - Y YV (1) محمد حسام لطفي ،المرجع السابق ، ص (1) (2) J. BONNARD ,op, cit, p.110-111

(r) تعرف بأنها القاعدة التي بموجبها يتم تخفيض التعويض المدفوع للمؤمن له بعد الخسارة بسبب الاغفال

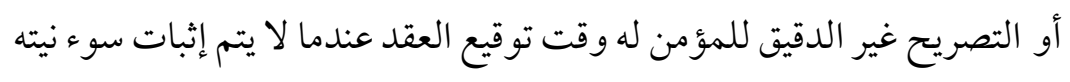

(4) J. BONNARD , op, cit,,p.110-111 


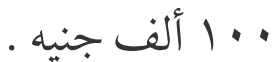

وفي هذه الحالة تم التخفيض بسبب الخطأ الذى ارتكبه المؤمن له رغم أنه خطأ غير مقصود إلا أن هذا التخفيض تم لاستعادة الرصيد المالي للعقد . ثانيا - عدم الاكتراث بحسن نية المؤمن له في حالة التأمين الناقص: يعرف التأمين الناقص بأنه الحالة التي يوجد فيها المؤمن له عندما تتجاوز قيمة الشيء المؤمن عليه مبلغ التأمين يوم المطالبة). في هذه الحالة يكون المؤمن مسئولا فتط عن الضرر الذى يتناسب مع مبلغ التأمين المتفق عليه بعقد التأمين ، وبذلك لا يتلقى المؤمن له سوى جزء من التعويض ويطبق ما يسمى قاعدة التناسبية بحكم الو اقع ()وهذه القاعدة تطبق سواء أكان المؤمن له حسن النية أو سيء النية فبمجرد أن يكون مبلغ التأمين أقل من القيمة الحقيقية للشيء فإن هذا الحكم يطبق. وتسمى القاعدة المطبقة في هذه الحالة بالقاعدة النسبية لرأس المال ، ويقوم تبرير هذه القاعدة على اعتبار أنه عندما أمن المالك على منزله بمبلغ أقل من قيمته الحقيقية فقد دفع قسطا يعادل هذا المبلغ ، ولو قام بالتأمين وفقا للقيمة الحقيقية للمنزل لدفع قسطا أعلى ، فهو قد دفع قسطا أقل مما كان يجب عليه أن يدفعه ، فإذا احترق المنزل كله فلن يتقاضى إلا مبلغ التأمين المتفق عليه والذى يكون أقل من القيمة الحقيقية للمنزل ل(r) في هذه الحالة تتحمل

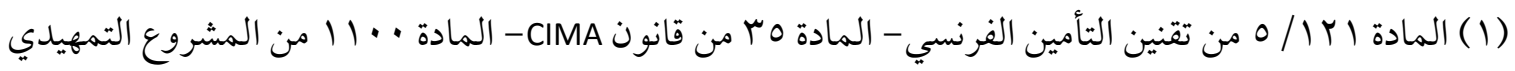

$$
\text { للقانون المدني }
$$

السنهوري ، المرجع السابق ص 07 • ب ف Y Y ب - برهام عطا اله ، المرجع السابق ص 101 - محمد حسام

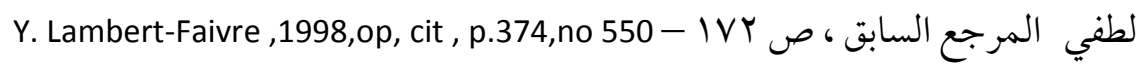

(Y) برهام عطا الهه ، المرجع السابق ص 101

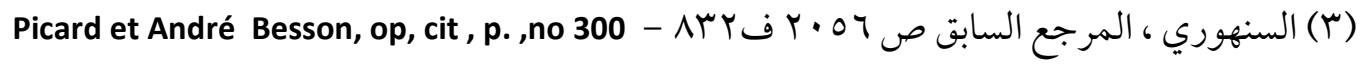


شركة التأمين الضمان عن جزء يعادل قيمة مبلغ التأمين ويعتبر المؤمن له هو الضامن

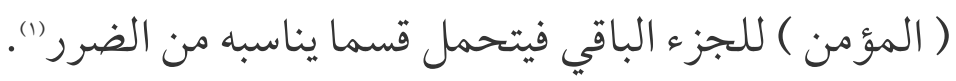

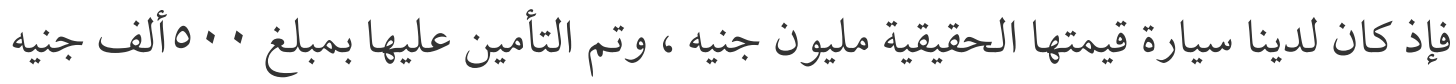
فبعد وقوع الكارثة يتم تحديد الخسارة وفقا لتقرير الخبير الفني فإذا قرر الخبير الفني أن

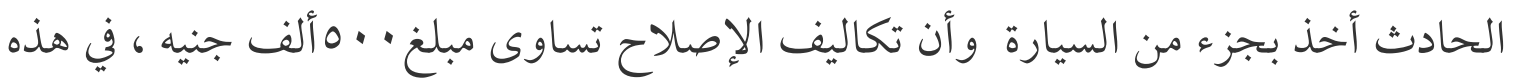

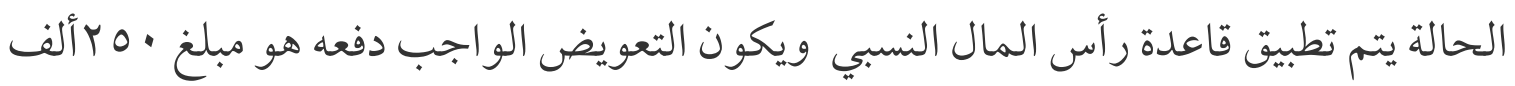
جنيه وذلك وفقا للمعادلة الرياضية التالية :

التعويض المستحق = الضرر الحقيقي × مبلغ التأمين / القيمة الحقيقية للسيارة

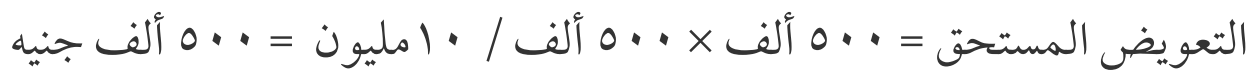
وقاعدة النسبية ليست من النظام العام فيجوز الاتفاق على ما يخالفها(")من ثم يجوز أن يشترط المؤمن له أن يتقاضى تعويضا كاملا عن الجزء الذى هلك مادام هذا التعويض الكامل

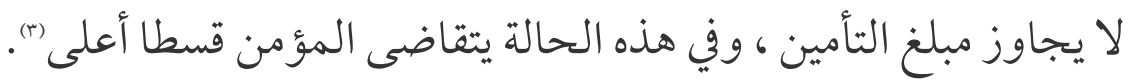
من خلال تخفيض التعويض الواجب دفعه وفقا لقاعدة النسبية نعيد التوازن بين فوائد كل من الأطراف") ونتأكد من أنه في كل مرة يكتشف فيها المؤمن خطأ غير مقصود من المؤمن له بعد وقوع الكارثة فإن التعويض المستحق سوف ينخفض بشكل يتناسب مع هذا الخطا ،

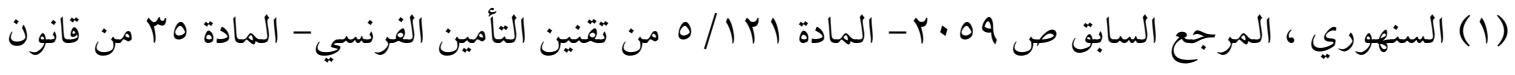

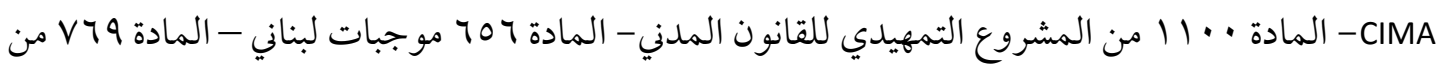

$$
\text { التقنين المدني الليبى }
$$

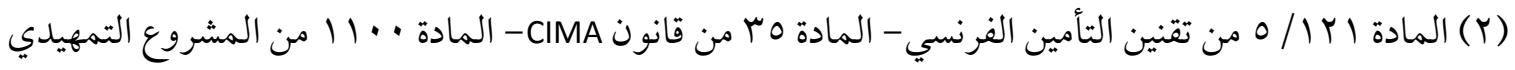

$$
\text { كلقانون المدني }
$$

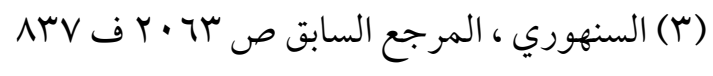

(4)- Eloïse Haddad, op,cit ,p.114 
وبذلك يكون تطبيق هذه القواعد بسبب حسن النية هدفه استعادة التوازن المالي الذى اختل

$$
\text { عن طريق الخطأ غير المقصود. }
$$

\section{ثالثا- دفع تعويض يصل إلى القيمة الحقيقية للشيء المؤمن عليه:}

إضافة إلى التخفيض النسبي للتعويض الذى يتعين دفعه للمؤمن له على النحو الوارد في الفقرة السابقة فإن هناك حالات في بعض عقود التأمين سيتم دفع تعويض من قبل شركة التأمين يصل فقط إلى القيمة الحقيقية للشيء المؤمن عليه وذلك دون الاعتداد بالقيمة

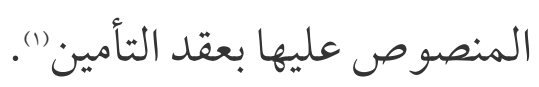

فإذا كان عقد التأمين على الأشياء فلا يمكن أن يتجاوز التعويض المستحق قيمة الشيء المؤمن عليه وقت حدوث الكارثة ؛ وذلك لأن عقد التأمين هو عقد تعويض (()هدفه تغطية مخاطر المؤمن له وليس إثرائه بلا سبب).

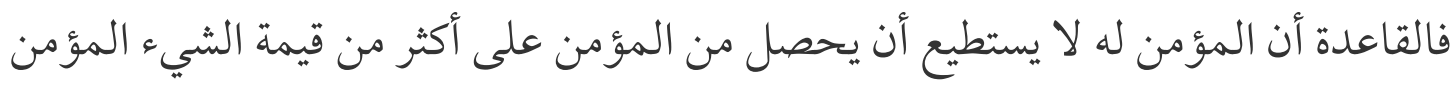

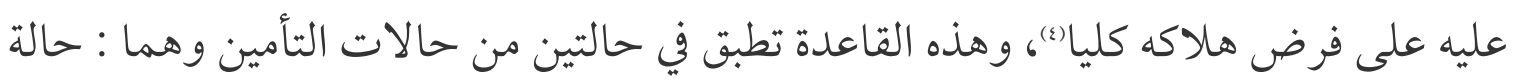
التأمين الزائد ( المغالى فيه ) ، وحالة تعدد عقود التأمين . (أ) دفع التعويض في حالة التأمين الزائد دون احتيال. نتحدث هنا عن زيادة التأمين عندما يتم الاتفاق على عقد تأمين بمبلغ أكبر من قيمة الشيء

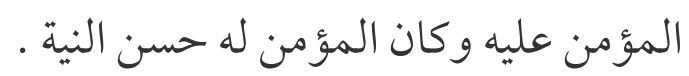

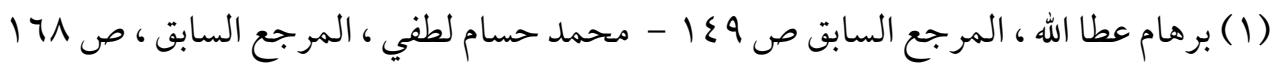

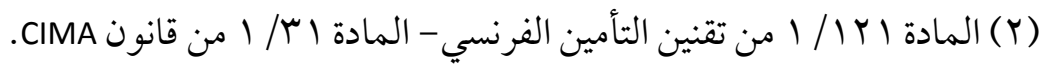

(3)Eloïse Haddad,op,cit, p.114

$$
\text { ( ) برهام عطا الله ، المرجع السابق ص } 9 \text { ـ }
$$


في هذه الحالة إذا تم إثبات وقوع الحادث المؤمن ضده فإن العرف التأميني (1)قد جرى على العمل بما هو مطبق في فرنسا() باعتبار العقد يبقى صحيحا ، ولكن التعويض يكون في حدود القيمة الحقيقية للأشياء المؤمن عليها(م)وليس المبلغ المتفق عليه ، ولا يحق للمؤمن له الحق في استرداد الزيادة في القسط()وإنما تبقى الأقساط حقا خالصا للمؤمن وكذلك أقساط السنة الحالية إذا كانت مستحقة مستقبلام(ن. فإذا هلك الشيء المؤمن عليه هلاكا كليا فإن شركة التأمين سوف تدفع للمؤمن له التعويض الذى يعادل القيمة الحقيقية للشيء المؤمن عليه ، أما إذا كان الهاكلك جزئيا فإن مبلغ التعويض الواجب دفعه سوف يتناسب مع القيمة الحقيقية للشيء حيث إن المؤمن له ليس بإمكانه الحصول على مبلغ يجاوز ما لحقه من ضرر فعلى (1)، فالتعويض الو اجب دفعه يساوى الأضرار الفعلية التي لحقت بالمؤمن له. فعلى سبيل المثال إذا كان التعويض المتفق عليه في حال التأمين على منزل ضد الحريق هو مليون ونصف جنيه ، فإذا هلك المنزل كله بسبب الحريق وكانت القيمة الحقيقية للمنزل هي مبلغ مليون جنيه ، في هذه الحالة لن تدفع الشركة إلا مبلغ مليون جنيه فقط ، أما إذا هلك

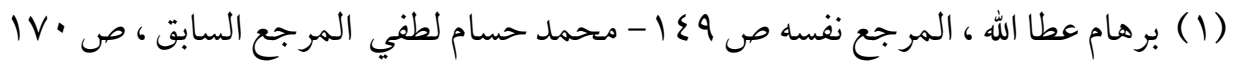

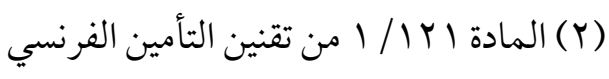

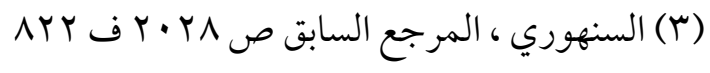

(ع)ياسين البكري ، الصفة التعويضية في عقد التأمين ، مجلة القانون المغربي ، المغرب ، ،العدد •ب ، مارس صرس 
نصف المنزل بسبب الحريق فإن شركة التأمين لن تدفع إلا نصف مليون جنيه. و التخفيض في هذه الحالة حتى يصل إلى القيمة الحقيقية للشيء المؤمن عليه لا يحدث تلقائيا ، بل يجب أن تطلبه شركة التأمين (1). فيما يتعلق باستمرارية العقد ، فيتم تخفيض قسط التأمين إلى القيمة العادلة اعتبارا من الأقساط التالية(1) أما بخصوص الأقساط المستحقة عن الفترة السابقة على حدوث الخطر فإنها تظل مستحقة لشركة التأمين وذلك على الرغم من تجاوزها قيمة القسط الحقيقي الواجب دفعه ؛ ومبرر ذلك هو تجنب صعوبات كثيرة منها ما هو متعلق بالمحاسبات الضريبية و المحاسبية التي قد تنشأ عنها'(r).

في هذه الحالة وجدنا حسن نية المؤمن له الذى يدلى ببيان خاطئ فيما يتعلق بقيمة الشيء المؤمن عليه يساعد فقط في استعادة التوازن المالي المختل ، وهذا ما يبرره حقيقة أنه لا يو جد أي جزاء منصوص عليه في هذه المسألة حيث إن العقد لا يزال ساري المفعول ، ولكن فقط يصل إلى القيمة الحقيقية للشيء المؤمن عليه وبالتالي يستلزم تعديل مالي للعقد ، يتعلق هذا التعديل بدفع التعويض المستحق وكذلك أقساط التأمين · (ب)دفع التعويض في حالة التأمين المتعدد : تتعدد عقود التأمين إذا قام المؤمن له بالتأمين على شيء واحد ولمصلحة و احدة ضد نفس

$$
\text { الخطر لدى اثنين أو أكثر من شركات التأمين (). }
$$

Henriette E. Kameni, op , cit ,p.133 - r.r^ السنهوري ، المرجع السابق ص (1) السنهوري ، المرجع السابق 357 Henriette E. Kameni, op , cit ,p.133 - Lamy assurances, 2005, op. Cit. p. $-\Lambda Y r \omega r \cdot r \Lambda ص$

(3) Henriette E. Kameni, op , cit ,p.133

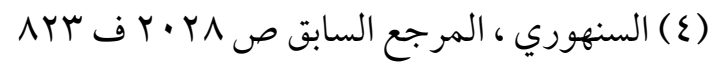


وقد لا يؤدى هذا التعدد إلى مجاوزة مبالغ التأمين لدى الشركات المؤمنة قيمة الشيء المؤمن عليه ، وذلك بأن يكون مجموع مبالغ التأمين في هذه العقود لا يزيد على هذه القيمة ، وفي هذه الحالة لا يكون في هذا التعدد مغالاة").

أما إذا كان قيمة مجموع مبالغ التأمين في هذه العقود تتجاوز القيمة الحقيقية للشيء المؤمن عليه فإننا نكون بصدد تأمين المغالاة أو التأمين التراكمي ().

فيكون هناك تأمين تراكمي عندما يتم ضمان نفس الشيء في وقت واحد من قبل اثنين أو أكثر من شركات التأمين ضد نفس الخطر وللمصلحة نفسها بحيث تتجاوز قيمة مبالغ التأمين

$$
\text { القيمة الحقيقية للشيء المؤمن عليه(()(المادة الب | / ع من تقنين التأمين الفرنسي) }
$$

فلكى يكون هناك حديث عن تأمين تر اكمي يجب أن يكون هناك مزيج من العناصر الأتية : تعدد شركات التأمين ، نفس الشيء ، نفس المخاطر ، تأمين متزامن ، ضمانات مشتركة لشركات التأمين ، تعلق التأمين بالتأمين ضد الأضرار لذلك يتم استبعاد التأمين على الأشخاص بسبب حقيقة أن المبدأ التعويضي لا يطبق في هذا النوع من التأمين ()كما يجب أن تكون كل هذه العقود صالحة للضمان وقت وقوع الحادث (م). عند إبرام العقود المذكورة يجب على المؤمن له إبلاغ كل شركة تأمين بقيمه بالتأمين على نفس الخطر لدى شركات التأمين الأخرى (1). في حال عدم إبلاغ المؤمن له لشركات التأمين بعقود التأمين المتعددة فينظر في هذه الحالة

(1) Beira Ehi Marc, op , cit , p.25

(2) Ibid, p.26

(3) Ibid- Picard et André Besson, op, cit , p.633,no211 - Y. Lambert-Faivre ,1998, op, cit , p.250, no 291

(4) Beira Ehi Marc, op , cit , p.70

(5) Ibid, p.27

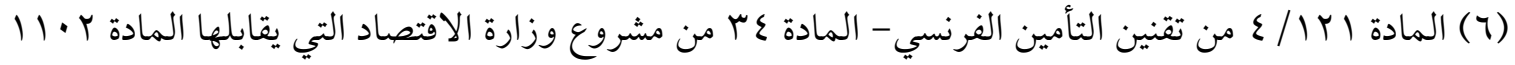
من المشروع التمهيدي للقانون المدني 
إلى خطأ المؤمن له في عدم الإبلاغ هل تم بسوء نية أم تم بحسن نية وغالبا ما يعرف هذا الخطأ في حال حدوث الكارثة ، فإذا ثبت سوء نية المؤمن له فإن جزاء ذلك هو بطلان عقود التأمين المتعددة التي أبرمها المؤمن له(1)وفي هذه الحالة يستبقى المؤمن أقساط التأمين التي قبضها وقسط السنة الجارية على سبيل التعويض. أما إذا كان عدم الإبلاغغ بحسن نية فإن كل عقد من العقود المبرمة يسرى مفعوله ضمن الحدود المضمونة للعقد وفقا لمبدأ التعويض ، وهذا يتم بغض النظر عن تاريخ إبرام كل عقد من عقود التأمين(). () من وفي هذه الحالة يلتزم كل مؤمن بدفع جزء من مبلغ التأمين يعادل النسبة بين المبلغ المؤمن عليه وقيمة التأمينات مجتمعة ، دون أن يجاوز مجموع ما يستوفيه المؤمن له من المؤمنين المتعددين قيمة الشيء المؤمن عليه وقت تحقق الخطر وذلك تطبيقا لمبدأ التعويض("). لتوضيح هذا الحكم نفترض أن سيارة قيمتها الحقيقية ، .0 ألف جنيه ، قام المؤمن له بالتأمين عليها لدى الشركة (أ)بمبلغ · . ب ألف جنيه ، وقام بالتأمين عليها لدى الشركة (ب) بمبلغ •0 ألف جنيه ، ليصبح بذلك إجمالي القيم المؤمن بها على السيارة هو •VO ألف

(1) وفقا للمادة /Y / / ع من تقنين التأمين الفرنسي والمادة اY / / فقرة أولى من تقنين التأمين الفرنسي- المادة

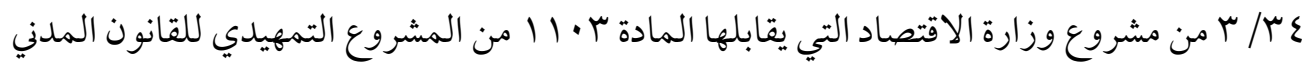

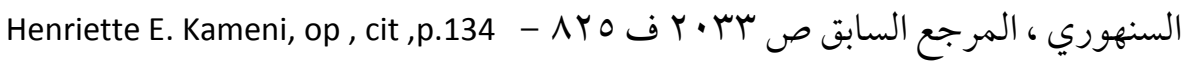

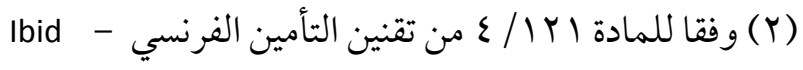

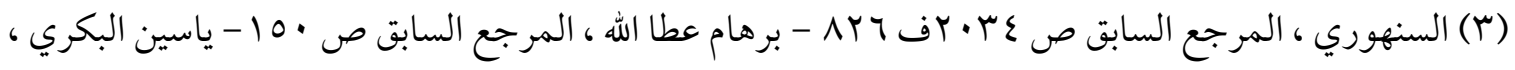

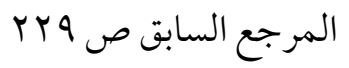

في القانون الفرنسي ووفقا للمادة اY / / ع من تقنين التأمين الفرنسي يو جد تضامن بين شركات التأمين مما يزيد من فرص تعويض المؤمن له بسرعة ، لذلك يجوز للمؤمن له أن يلجأ إلى أي شركة من شركات التأمين المتعاقد معها لتدفع له كامل مبلغ التأمين . 
جنيه وهو مبلغ يتجاوز قيمتها الحقيقية البالغ ..0 ألف جنيه .

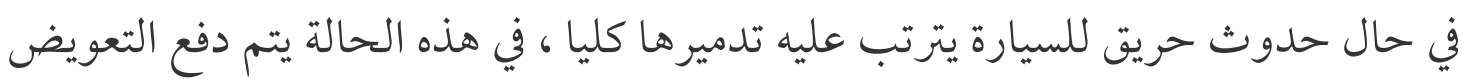

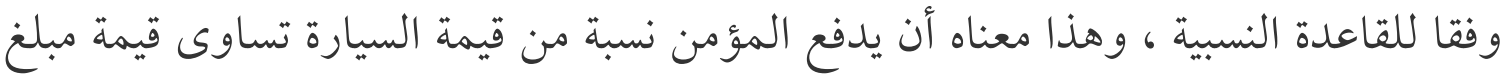

$$
\text { التأمين إلى القيمة الحقيقية . }
$$

فيحسب التعويض الواجب دفعه من أي شركة منهما وفقا للمعادلة الرياضية التالية"):

التعويض المستحق من الشركة (أ) = قيمة مبلغ التأمين لدى الشركة (أ) × القيمة الحقيقية

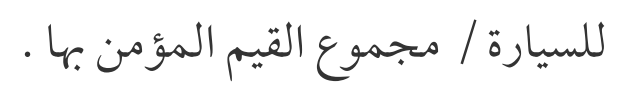

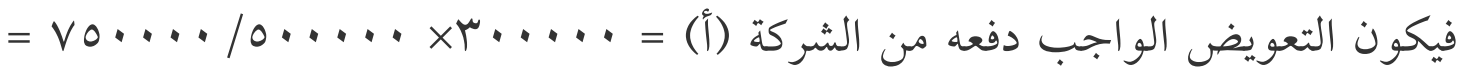

$$
\text { . }
$$

ويكون التعويض الو اجب دفعه من الشركة (ب)= = N

$$
\text { P..... }
$$

وفي هذه الحالة يكون إجمالي قيمة التعويضات يساوى مبلغ السيارة الحقيقي وليس مجموع المبالغ المؤمن بها ، ويكون تطبيق هذه القاعدة النسبية هدفه استعادة التوازن المالي

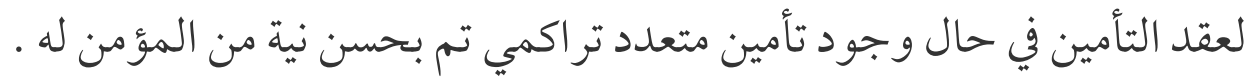

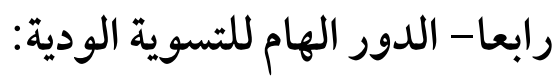

تعول شركات التأمين كثيرا على الدور الذى يمكن أن تلعبه التسوية الودية كأحد وسائل دفع التعويضات للمؤمن له بدلا من اللجوء إلى القضاء"(()فحق لشركات التأمين إجراء

(1) GATSI (J),op,citv p.68

(2) Robert W. Emerson, insurance Claims Fraud Problems and Remedies, University of Miami Law School, Institutional Repositor y,3/1/1992, p.924 - Karen Ann Gill, op , cit ,p. , p.181-182- محمد نبهى

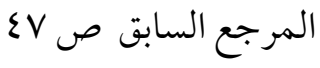


التسويات مع عملائها"(1) ذلك في حال وجود نزاع بينها وبين المؤمن له سواء كان هذا النزاع بسبب الخلاف بينهما في تحديد قيمة الخسارة أو التعويض المطلوب ، أو في حال مخالفة أي من طرفي العقد للاشتراطات والالتزامات التي تختلف حسب نوع التغطية. فيحق للمؤمن والمؤمن له التنازل عن بعض من حقوقهم المالية والتنازل عن التمسك بها مقابل اجراء التسوية بينهم بعيدا عن اللجوء إلى القضاء(") . في القانون المصري ووفقا للمادة ع ع ع من اللائحة الثنفيذية لقانون الإشراف والرقابة على التأمين يقوم العميل باللجوء إلى الهيئة العامة للرقابة المالية - والتي من ضمن اختصاصاتها الرئيسية الحفاظ على حقوق حملة الوثائق - للفصل في موضوع الشكوى من خلال لجنة فض المنازعات بالهيئة والتي تضم بعض الخبرات التأمينية والقانونية من داخل الهيئة والاتحاد المصري للتأمين بالإضافة إلى خبرات تأمينية مختلفة من سوق التأمين

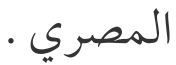
في حال قبول طرفي النزاع - الشركة والمؤمن له - للرأي الفني والقانوني للجنة يتم تسوية التعويضات بشكل ودى وفقا لما يتم الاتفاق عليه برضاء تام لكلا الطرفين (r).

(1) تتم التسوية الودية في القانون الفرنسي وفقا لأحكام المواد ع ـ ب وما بعدها من القانون المدني

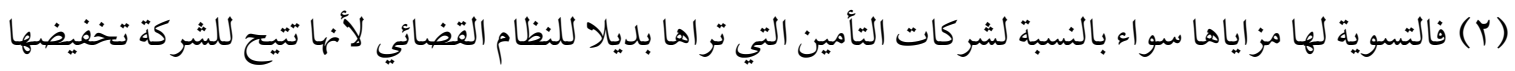

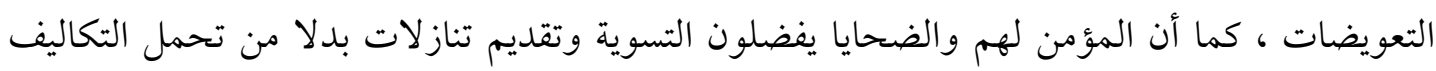

$$
\text { القانونية وبطء إجراءات التقاضي }
$$

(r) تمتاز التسوية الودية بقلة التكلفة والسرعة في البت والمرونة والحفاظ على العلاقات ، كما تمتاز بمشاركة وتعاون أطر اف النزاع في إيجاد حل يكون أكثر قبولا لدى الأطراف " وليد سليمى ، أحمد الصيد ، المرجع

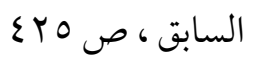




\section{دوافع اختيار أطراف النزاع التسوية كحل وسط.}

التسوية الودية كونها إجراء قانوني يقوم به طرفي عقد التأمين ما هي إلا اتفاق أو عقد

$$
\text { مكتوب"(1)بمو جبه ينهي الطرفان النزاع بينهما عن طريق تقديم تناز لات متبادلة. }
$$

وهناك أسباب كثيرة تدفع بطرفي عقد التأمين إلى الاتفاق على تسوية النزاع بينهم بهذه

الطريقة الودية بدلا من اللجوء إلى النزاع القضائي الذى يتسم بالتأخير وطول المدة بسبب

بطء إجراءات التقاضي"(r) حيث إنها تمنح العميل التعويض في فترة وجيزة(1)وكذلك الطبيعة

$$
\text { التقديرية والمتباينة للمبالغ التي تمنحها المحاكم كتعويض عن الأضرار التأمينية . }
$$

هذه التسوية تتسم كذلك بكونها توفر الكثير من المال الذى ينفق على نفقات التقاضي من

رسوم قضائية وأتعاب محامين ، كما أنها تلعب دورا هاما في الحفاظ على سمعة شركات

$$
\text { التأمين بدلا من تداول اسمها في ساحات القضاءع) }
$$

ويرجع لجوء شركات التأمين للتسوية الودية لتسوية تعويضات العملاء لأسباب كثيرة منها

كون العميل في بعض الأحيان على درجة كبيرة من الأهمية خاصة إذا كانت محفظة أعماله

(1) وفقا لنص المادة ع • ب من القانون المدني الفرنسي فإن التسوية عقد ينهى بموجبه الأطراف نزاعا موجودا

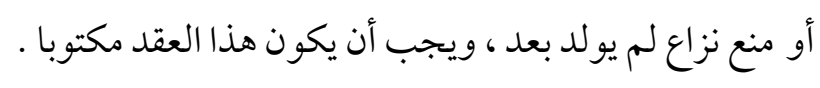

Cass., 2e chambre civ., 18 mai 2000, n 98-18.129, RGDA 2000, p. 848, note Philippe Rémy (Y) محمد نبهى ، المرجع السابق ص Henriette E. Kameni, op , cit,p.13 - محمد سلام ، دور الطرق

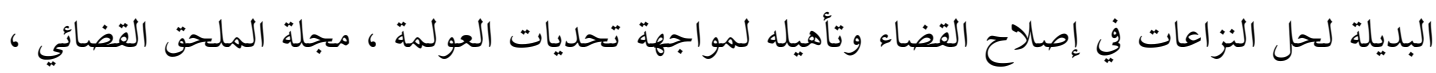

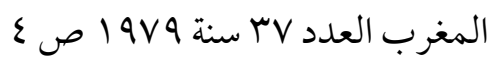

(3) Karen Ann Gill , op , cit ,p.182. -Robert W . Emerson, op , cit ,p.924

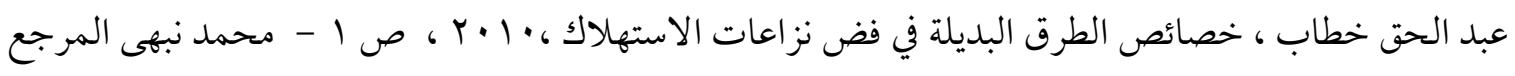

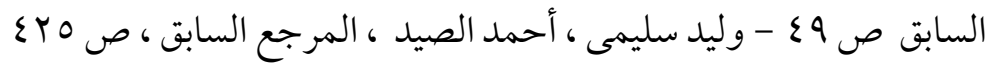

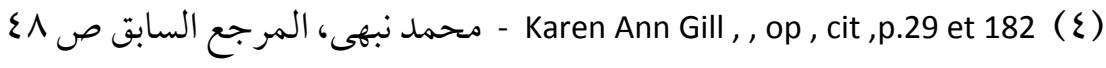


المالية بالشركة كبيرة ومعدل خسائره منخفض ، فرغبة منها للحفاظ على هذا العميل (1)ورغبة منها لاستقطابه و الحصول على عقود تأمين أخرى لهذا العميل خاصة إذا كان له عقود تأمين أخرى لدى شركات تأمين أخرى ، كما أنه كثيرا ما تلجأ شركة التأمين للتسوية الودية لمساعدة العميل للعودة إلى نشاطه التجاري و الصناعي . كذلك فإن العميل قد يكون لديه أسبابه هو الأخر للجوء للتسوية الودية ، فقد يجد العميل أن اللجوء إلى القضاء يفقد التعويض قيمته المالية خاصة مع طول فترة التقاضي وانخفاض سعر العملة وهو ما يؤخر عودة العميل للاستمرار في نشاطه ، خاصة وأن بعض القضايا قد تستمر لسنوات طويلة ووفقا لظروف المحكمة ونوع الدعوى المرفوعة أمامها ، هذه المدة الطو يلة تتو الى فيها المتغيرات الاقتصادية)(s). التسوية الودية يجب أن تكون نتاج وانعكاس لإرادة ناتجة عن موافقات أطراف عقد التأمين(r) التي قد يقابلها بعض التحديات الجديدة والمتوقعة ؛ والتحدي هنا يكمن في وجود صعوبة في التعويض عندما يكون هناك اعتر اف بوقوع الحادث عن غير قصد ، فللحديث عن تسوية يجب أن يكون الطرفان على استعداد لتقديم تنازلات ، وهذا يعنى تسوية نزاعهما من خلال أسلوب محدد لحل الخلافات ، فعندما تكون هذه هي إرادتهم المشتركة ، فعليهم أن يو افقوا في النهاية على البنود المختلفة لاتفاقهم الودى().

(1) تمتاز التسوية الودية بقلة التكلفة والسرعة في البت والمرونة والحفاظ على العلاقات .

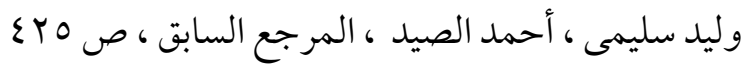
(ץ) -عبدالكريم عروي - الطرق البديلة في حل النزاعات القضائية ، الصلح والوساطة، رسالة ماجستير -جامعة

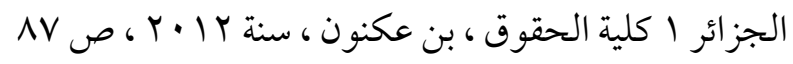

$$
\begin{aligned}
& \text { Karen Ann Gill , , op , cit ,p.182 - محمد نبهى ، المرجع السابق ص بع }
\end{aligned}
$$

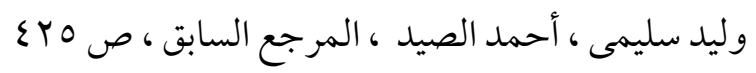


لكى نكون قادرين على الحديث عن تسوية ودية يتعين على أطراف النزاع تقديم تناز لات متبادلة")وهذه التنازلات تعنى أن كل طرف يجب عليه التخلي عن جزء من حقوقه على الأقل ولا يهم إذا كانت تنازلات أحد الأطراف أكبر من تنازلات الطرف الآخر (().

فيجب للاستفادة بهذه الميزة التي تقدمها التسوية الودية أن يتخلى كل طرف عن بعض المزايا المعترف له بها والمتو افقة مع عنصر الضمان(r) : على سبيل المثال في وثيقة التأمين ضد الحريق يلتزم العميل بأن يمتلك وسائل مكافحة الحريق ، وفي حال تخزينه للبضائع يجب أن يتم وفقا للأصول الفنية والتي منها تركك مسافة بين البضاعة حتى يتمكن رجال الإطفاء من إخماد الحريق بسهولة ؛ حيث يؤدى تكدسها إلى صعوبة عملية الاطفاء وسرعة انتشارها ومع ذلك فإن أغلب العملاء لا يلتزمون بالشروط الواردة بالوثيقة ، ويكتشف خبراء المعاينة دائما عدم وجود وسائل مكافحة الحريق ، أو غالبا ما تكون طفايات الحريق فارغة ، أو غير صالحة ؛ وذلك بخلاف تكدس البضائع بالمخازن . كذلك بالمثل يشترط على سائقي سيارات النقل البرى الالتزام بالحمو لات المقررة ، وفي أغلب الأحيان يتضح أنها محملة بضعف حمولتها المقررة في الرخصة مما يؤدى إلى فقدان توازنها وزيادة احتمالات انقلابها أو تصادمها مما يتسبب في زيادة الخسائر التي تتحملها

(1)- Cass., 1re civ., 29 mai 1990, n 98-16.458 - Cass., 2e ch. civ., 19 octobre 2006

" l'Argus de l'assurance ", hors série « Jurisprudence ", mars 2008, p. 88, note Gérard Defrance"

(r) فالنية الحسنة تلعب ركن أساسي في التخلي عن بعض الحقوق من أحد الأطراف لصالح الطرف الأخر

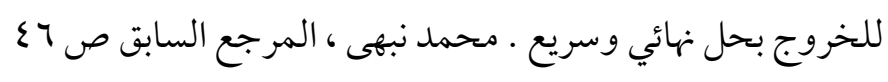

(r) - تشترط محمة النقض الفرنسية أن تتم التسوية متو افقة مع عنصر الضمان في عقد التأمين لذلك لم تعترف بالاتفاق الذى تم على تكاليف الجنازة باعتباره تسوية ودية ؛ وذلك لأن هذا الاتفاق لم يعالج الجانب الأخر

$$
\text { المتعلق بعنصر الضمان وهو التعويض عن الأضرار الاقتصادية . }
$$

Cass., 1re civ., 18 septembre 2002, n 00-14.773, RGDA 2002, p. 1042 note Philippe Rémy 


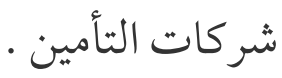
مخالفات العميل تدفع شركات التأمين إلى رفض سداد التعويض في بعض الأحوال حيث تكون هذه المخالفات سببا رئيسيا في وقوع الحادث ، ومع ذلك فإن شركات التأمين قد ترى تحمل العميل جزءا من الخسارة نتيجة إهماله أو عدم التزامه بشروط الوثيقة ، وفي هذه الحالة سيكون تعويض العميل غالبا بقيمة أقل من الخسارة الفعلية. كذلك يمكن أن ترتكب شركة التأمين خطأ دون قصد بعد تحقق المخاطر المؤمنة ، هنا التسوية تكون بدفع تعويض أكبر من التعويض المتفق عليه ؛ وذلك كاعتراف بالذنب و الخطأ ولتجنب المحاكمة التي تشوه سمعة الشركة(1)، ويكون ذلك في مقابل تنازل المؤمن له عن رفع الدعوى القضائية ضد شركة التأمين ، وفي هذه الحالة يفوز المؤمن له بمبلغ التأمين الذى يفوق توقعاته(r) - م

في كل هذه الحالات تنشأ الحاجة إلى التسوية الودية بين طرفي عقد التأمين والتي توفر على كل طرف الوقت والمال ، وفي هذه التسوية يخرج الأطراف بمصالحة تزيل كل الخلافات(م)وبحل يكون أكثر قبو لا لديهم (2) يستفيد كل منهم من التنازلات المتبادلة والتي تنتهي بتوقيعهم هذه التسوية(مالتي ترفق كملحق لعقد التأمين المبرم سابقا بينهما()ويستبع

محمد نبهى، المرجع السابق ص Karen Ann Gill , , op , cit ,p.182 (1) (2) Henriette E. Kameni, op , cit ,p.139

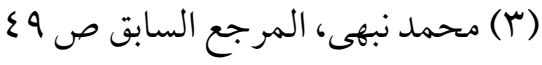

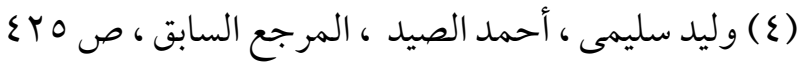

(5) Henriette E. Kameni, op , cit ,p.139 (7) حيث تعتبر محكمة النقض الفرنسية أن الإجراءات في تنفيذ معاملة التسوية الودية للمطالبات امتدادا لعقد التأمين وتخضع لأحكامه . Cass civ . 2.19 novembre 13-23-090. 2015 
ذلك تنفيذها وفقا لبنودها ومحتواها ، وفي حال تهرب أي طرف من أطراف التسوية عن تنفيذها تطبق عليه العقوبات المتعلقة بعدم تنفيذ العقود.

\section{الإعفاء التام للمؤمن عليه المرتكب خطأ بحسن نية.}

إن التسوية الودية لا تتم الا بتقديم تنازلات متبادلة من طرفي عقد التأمين ، ولا يهم كما

$$
\text { سبق القول إذا كانت تناز لات أحد الأطر اف أكبر من تنازلات الطرف الآخر. }
$$

في بعض الحالات قد تتنازل شركة التأمين كليا عن التمسك بخطأ المؤمن له حسن النية

عندما يكتشف في حال حدوث المطالبة ، ويترتب على ذلك حصول المؤمن له على التعويض الكامل ويكون المبرر في هذه الحالة هو الرغبة الكبيرة لشركة التأمين في الحفاظ على

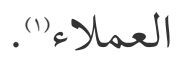

فشر كات التأمين تشعر بالقلق إزاء ولاء العملاء ؛ لذلك فإنها إذا ما تعاملت مع عميل جيد يتعامل معها لفترة طويلة وله محفظة مالية كبيرة بالشركة ، ولم يسبق أن تحققت مخاطرة في فرع من فروع التأمين التي يتعامل فيها ، أو حتى على الأقل خسائره منخفضة ، فإنها تقوم بإعفائه إعفاء تاما وكليا من خطأه المرتكب بحسن نية . الهدف من هذا الإجراء هو الحفاظ على العلاقة التعاقدية الوثيقة بينهما وتعزيز جدار الثقة التي يحتاجها العميل بشدة ؛ لضمان ولائه الذى يعد رأس مال حقيقي لشركة التأمين(). وهذا الإجراء يندرج تحت الإرادة الأحادية للمؤمن الذى يمكن أن يمنح هذا الإجراء لأحد المؤمن لهم ويرفضه بالنسبة للآخر ، ويتم تحليل هذا الإعفاء كمكافأة للمؤمن له الذى يتعامل بنز اهة وحسن نية تجاه شركة التأمين الخاصة به .

(1) Lamy assurances, 2005 ,op.cit, p 359

(Y) مزوار محمد أمين ، ولاء عملاء التأمين ، رسالة ماجستير في العلوم الادارية (باللغة الفرنسية ) ، جامعة أبى بكر

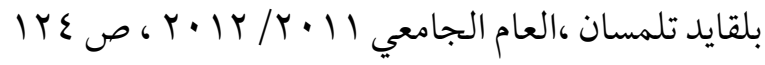


ويذلك يكون لهذه الممارسة الأثر الكبير على سوق التأمين ، فبذلك الإجراء يحصل المؤمن على ثقة المؤمن له الذى سيظل مرتبطا بشركة التأمين لتغطية جميع احتياجاته ووفقا لقدراته كما سيزيد من ولاء المؤمن له الذى سوف يجلب أصدقائه وأقاربه للاشتراك لدى شركة التأمين الخاصة به ، وهذا الإجراء يساهم في تعزيز مجال التأمين ؛ بسبب استخدام المؤمن له كوكالة إعلانية .

ورغم وجاهة هذا الإجر اء خاصة إذا كان القصد منه استعادة الثقة بين المؤمن والمؤمن له وهذا أمر مشجع للغاية ؛ إلا أن هذا الإجراء قد يؤدى إلى كارثة ، خاصة وأن هذا الإجراء تقديري ولا يتمتع بهذه الميزة جميع المؤمن لهم ، ومن ثم فإن هذه المعاملة تصبح غير متكافئة وغير عادلة للمؤمن لهم جميعا خاصة إذا كان هناك استيفاء لنفس الشروط لدى المؤمن لهم ، مما سيخلق تشويشا حفيفا في عقول المؤمن لهم ، ومن ثم يشكل عقبة حقيقية

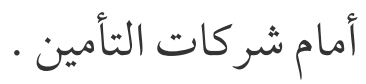
كذلك فإن هذا الإجر اء سيكون له أثر كبير على تكلفة التأمين ؛ لأنه سيوجد فارقا كبيرا بين التكلفة الحقيقية للتأمين وبين الأقساط المستحقة . لذلك يجب على شركات التأمين من أجل ضبط هذا الإجراء أن تقوم في جمعياتها العامة بتحديد الخطوط العريضة لهذا الإجراء بدقة ؛ وذلك من أجل تقليل آثاره الضارة والتمكن من الحصول على جميع مز اياه ، و التي تكون مفيدة للغاية لتنشيط قطاع التأمين. 


\section{خاتمهة البحث}

من خلال دراستنا لحسن النية في عقد التأمين ، توصلنا إلى مجموعة من النتائج تتلخص فيما يلى :

1 -فكرة حسن النية تأتى في سياق العلاقة بين القانون والأخلاق ، فهي تشكل نقطة اتصال وامتزاج بهما ، و الاعتداد بها يكفل مو افقة القانون لقواعد الأخلاق على نحو أفضل ؛ لذلك نجد حرص المشرع على تقنين هذه الفكرة وتجسيدها. وفي ذلك يقضى نص المادة ع • 11 مدنى فرنسي بوجوب التفاوض على العقود وإبرامها وتنفيذها بحسن نية ، كما يقضى نص المادة ^^§ ا مدنى مصري بأنه يجب تنفيذ العقد طبقا لما اشتمل عليه وبطريقة تتفق وما يوجبه حسن النية.

وحيث أن النص الفرنسي أوجب حسن النية في كل مراحل التعاقد ، في حين أن النص المصري تحدث فقط عن وجوب حسن النية في مرحلة تنفيذ العقد ؛ لذلك نناشد المشرع المصري بتعديل نص المادة ^^§ ا مدنى مصري ليصبح مثل نص المادة ع • 11 فرنسي التي توجب التفاوض على العقود وإبر امها وتنفيذها بحسن نية. r - حسن النية مطلب ملح في مختلف الالتزامات القانونية والتعاقدية والعملية ، وهو مطلب أكثر إلحاحا في عقد التأمين ، فلا يمكن أن يكون عقد التأمين فعالا وينتج عنه الآثار المتوقعة إلا من خلال الأداء الصحيح من جانب الأطراف لالنز اماتهم بكل شفافية وحسن

فحسن النية ضروري في جميع مراحل العقد سواء في مرحلة المفاوضات حيث يجب أن يكون كل طرف من أطراف عقد التأمين مخلصا للطرف الآخر ، كذلك هو الحال عند إبرام أو تنفيذ العقد حيث يدين كل منهما للأخر بالوفاء الصادق للالتزامات التي قطعها على نفسه وفقا للمتطلبات القانونية . 
ץ- يعد حسن النية في عقد التأمين وسيلة لتنظم التزام المعلومات الذى يعد الالتزام الأساسي بعقد التأمين ، والذى ينبني عليه صحة باقي التزامات أطر اف عقد التأمين ، وفي هذا الجانب فإن التزام المعلومات في قانون التأمين معترف به جيدا ولكن بخصوصية كبيرة حيث لا يقتصر الأمر في الالتزام بالمعلومات على عاتق شركة التأمين باعتبارها المهني المحترف الذى يجب عليه إعلام المؤمن له باعتباره المستهلك غير المهني ، و إنما هذا الالتزام يقع في الوقت نفسه على الأخير . فإذا كانت شركة التأمين ملتزمة بتقديم ورقة معلومات عن السعر والضمانات، وكذلك تقديم المشورة قبل إبرام العقد ، كذلك فإن المؤمن له ملتزما بالإعلان عن المخاطر سواء الأولية أو أثناء تنفيذ العقد ، وكذلك إعلان المطالبة.

فتبادل المعلومات نظام مستدام يفترض فيه الشفافية وحسن النية من وقت التفاوض على العقد وحتى حدوث الخسارة وإعلان المطالبة . ع - أداء أطراف عقد التأمين لالتزاماتهم بحسن نية يجنبهم العقوبات القانونية التي تقع على المخل بهذا الالتزام ، سواء كان هذا العقاب مدنيا يتمثل في بطلان عقد التأمين بالإضافة إلى التعويض عن الأضرار والذى يعد العقاب الأساسي ، أو العقاب الجنائي في بعض الحالات من خلال عقوبات الحبس أو السجن أو دفع الغرامة ، وهذه العقوبات تضمن أداء أطر اف عقد التأمين لالتز اماتهم بحسن نية . 0- بطلان عقد التأمين كجزاء على الإخلال بالالتزام بالإعلام يختلف تماما عن البطلان الو ارد بالقو اعد العامة للقانون المدني ، حيث لا يشترط وجود علاقة سبية بين الكتمان أو البيان الكاذب وبين تحقق المخاطر أو حدوث ضرر من جراء هذا الصمت أو الكذب المتعمد. فالبطلان يحكم به حتى ولو لم تتحقق المخاطر أو يحدث ضرر اللمؤمن. كذلك يكون لبطلان عقد التأمين أثر رجعى ، لكن هذا الأثر الرجعى له طبيعة خاصة ، 
بحيث يمكن للمرء أن يشكك في مدى كفاية المصطلح المستخدم من قبل المشرع ،

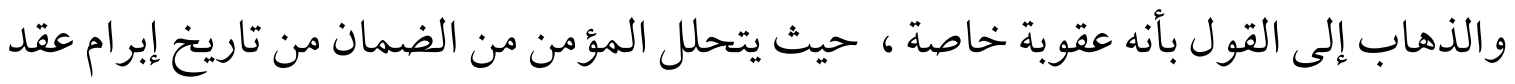
التأمين ، في حين أن المؤمن له يظل ملتزما بدفع الأقساط عن المدة السابقة على استعمال المؤمن له لحقه في الإبطال ؛ ويبرر ذلك باعتبار هذه الأقساط كتعويض عن الأضرار التي لحقت المؤمن بسبب خطأ المؤمن له وخرقه للعقد. كذلك يلتزم المؤمن له برد ما يكون قد قبضه من مبالغ تأمين بمناسبة نفس الوثيقة عن ذات الخطر ، علاوة على الفو ائد القانونية عن هذه المبالغ من تاريخ قبضه . 1- حسن النية في عقد التأمين يتجاوز الالتزام بالإعلام ، حيث يؤدى حسن النية في عقد التأمين إلى إنشاء واجب الو لاء والمشورة والتعاون من جانب طر في عقد التأمين . V- بالإضافة إلى الدور الذى يقوم به حسن النية كوسيلة للإشر اف على الالتزامات التعاقدية وخاصة التزام المعلومات، فإن حسن النية يهدف إلى الحفاظ على التوازن المالي لعقد

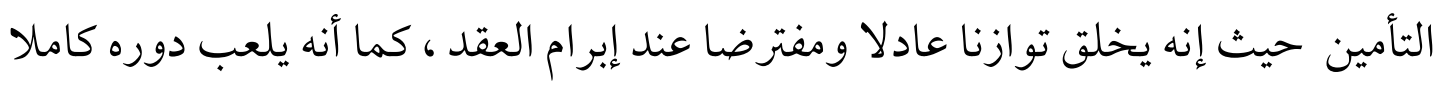

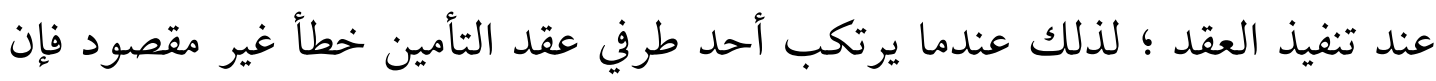
عقوبته تكون طفيفة لدرجة أنها تفقد طابعا العقابي ؛ لتحافظ على التوازن المختل بسبب لئل الخطأ غير المقصود المرتكب بحسن نيه. 1- يعول كل من المؤمن له وشركات التأمين كثير اعلى الدور الذى يمكن أن تلعبه التسوية

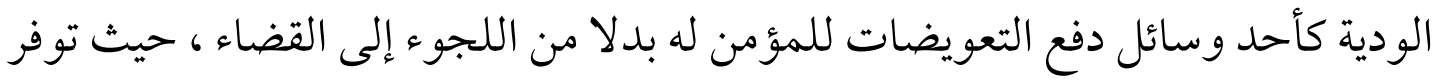
على كل طرف الوقت والمال ، وفي هذه التسوية يخرج الأطراف بمصالحة تزيل كل

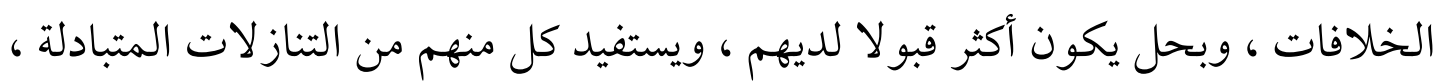
والتي قد تكون أكثر فائدة لمرتكبي الأخطاء بحسن نية. 


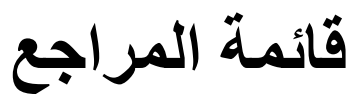

أولا : المراجع باللغة العربية

1 - المؤلفات العامة

د. أحمد شرف الدين ، أحكام التأمين ، دراسة مقارنة في القانون والقضاء المقارنين

نادى القضاة ، الطبعة الثالثة ، سنة 1991

د. السيد عمران ، الموجز في أحكام عقد التأمين ، الناشر دار الفتح للطباعة والنشر

بدون سنة نشر

د. برهام محمد عطا الله ، عقد التأمين من الوجهة القانونية والشرعية طبعة r ب. r

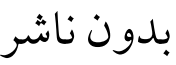

د. رمضان أبو السعود ، أصول التأمين ، دار المطبوعات الجامعية الاسكندرية ... P.

د. عبدالرزاق أحمد السنهوري ، الوسيط في شرح القانون المدني ، الجزء السابع

المجلد الثاني ، عقود الغرر ، عقود المقامرة والرهان والمرتب مدى الحياة وعقد

التأمين ، الطبعة الثانية ، تنقيح المستشار مصطفي محمد الفقي ، الناشر دار النهضة

$$
\text { العربية ، سنة }
$$

د. .عصام سليم ، العقود المسماة ، عقود الغرر ، عقد التأمين ، الناشر دار الجامعة

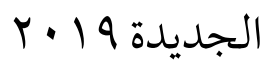

د. محمد حسام لطفي، الأحكام العامة لعقد التأمين ، دراسة مقارنة بين القانونين

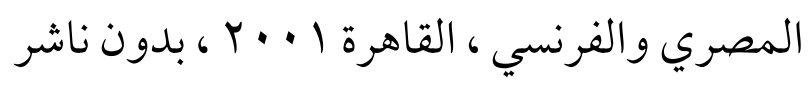

د. محمد حسين منصور ، مبادئ قانون التأمين ، دار الجامعة الجديدة ، الاسكندرية

$$
\text { بدون سنة نشر }
$$


Y - ب المؤلفات المتخصصة والرسائل والمقالات

د. أشرف جابر سيد ، الاستبعاد الثقافي من الضمان ، دراسة مقارنة بين القانونين المصري والفرنسي ، مجلة حقوق حلوان للدراسات القانونية والاقتصادية ، الصادرة عن كلية

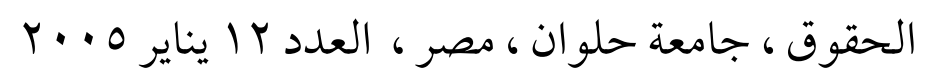
أمينة سي عمر و تركية شاينه ، مبدأ حسن النية في العقود تأصيلا وتحليلا ، رسالة ماجستير ، المركز الجامعي بلحاح بوشعيب ، معهد العلوم الاقتصادية وعلوم التسيير

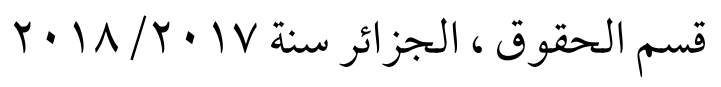
حسن حدون ، التكافل العقدي، رسالة ماجستير ، جامعة الجزائر ا بن يوسف بن خدة كلية الحقوق سعيد حمدين ، العام الجامعي 10 حفيظ دحمون ، التوازن في عقد التأمين ، مجلة القانون ، منشورات المركز الجامعي

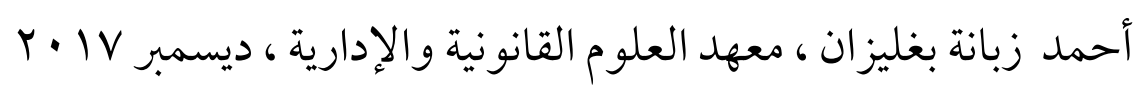
خاطر نورى حمد وآخرين - الأساس القانوني لالتزام المؤمن له تقديم المعلومات-

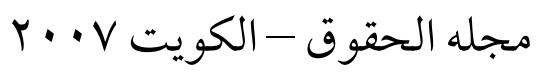
ساره لحلاح ، زينه لعيدي ، الحماية القانونية للطرف الضعيف ، رسالة ماجستير جامعة عبد الرحمن ميره ، بجايه ، قسم القانون الخاص ، العام الجامعي 10 • r/ 1 • • اسفيان الفرجي ، واجب حسن النية في تنفيذ العقود في القانون التونسي والقانون المقارن ، رسالة دكتوراه ، كلية الحقوق والعلوم السياسية بتونس ، جامعة تونس المنار ، السنة الدراسية $r \cdot 11 / r \cdot 1 \cdot$ سماح جبار ، القيمة القانونية للعنصر الأخلاقي في العقود الخاصة رسالة دكتوراه كلية الحقوق والعلوم السياسية ، جامعة أبى بكر بلقايد تلمسان ، الجزائر ، العام الجامعي

$$
r \cdot 11 / r \cdot 1 V
$$


د. عابد فايد ، تصور حديث لالتزام المؤمن في عقد التأمين ، مجلة الدراسات القضائية ، معهد التدريب والدراسات القضائية ، وزارة العدل الامارات العربية المتحدة ، العدد

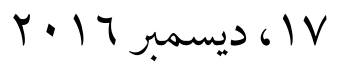
عبدالكريم عروى ، الطرق البديلة في حل النزاعات القضائية ، الصلح والوساطة رسالة

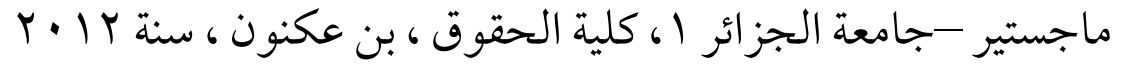
عرعارة عسالي ، التوازن العقدي عند نشأة العقد ، رسالة دكتور اه، جامعة الجزائر ا كلية

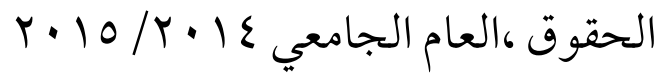
عمرو جويده - حماية مستهلكي التأمين - رسالة دكتوراه ، جامعة الجزائر ا، كلية

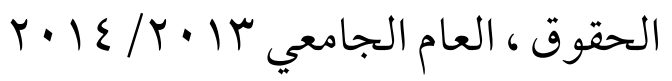
فاطمة الزهراء زيتوني ، مبدأ حسن النية في العقود ، رسالة دكتوراه ، كلية الحقوق والعلوم

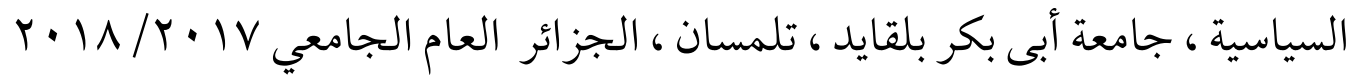
محمد الهيني ، الحماية القانونية للطرف الضعيف في عقد التأمين البرى ، دراسة مقارنة ، الناشر مكتبة دار السلام للطباعة والنشر والتوزيع المغرب محمد نبهي ، الطرق البديلة لتسوية النزاعات التجارية ، رسالة ماجستير ، جامعة

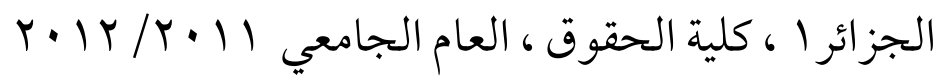
مريم طويل ، قانون السوق وفكرة توازن مصالح المنتج وحقوق المستهلك دراسة مقارنة ، كلية الحقوق والعلوم السياسية ، جامعة أبى بكر بلقايد تلمسان ، الجزائر سنة

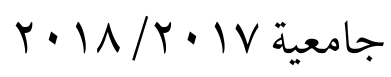

هدى بن أيوب ، مبدأ حسن النية في العقود ، رسالة ماجستير ، جامعة العربي بن مهيدى ،

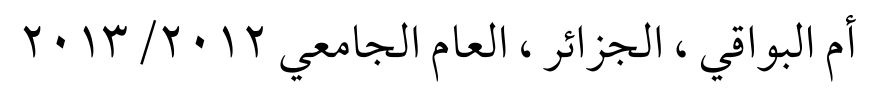

وليد سليمى ، أحمد الصيد ، ضمانات التوازن لتنفيذ عقد التأمين ، مجلة الحقوق 


$$
\begin{aligned}
& \text { والعلوم الإنسانية ، جامعة زيان عاشور بالجلفة ، الجزائر، المجلد } 11 \text { العدد الأول } \\
& \text { مارس (1) } \\
& \text { - ياسين البكري ، الصفة التعويضية في عقد التأمين ، مجلة القانون المغربي ، العدد • ب، }
\end{aligned}
$$

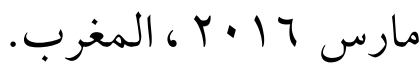

$$
\begin{aligned}
& \text { ثانيا : المراجع باللغة الغرنسية }
\end{aligned}
$$

\section{1-Ouvrages generaux ,cours et traits}

1- FAIVRE- ROCHEX et G. COURTIEU, le droit du contrat d'assurance terrestre, LGDJ, 1998

2- Picard et André Besson, , Les assurances terrestres, t.1 "le contrat d'assurance" 5 ed, Paris, L.G.D.J., 1982

3- Yvonne Lambert-Faivre, Droit des assurances, 10 éd., Paris, Dalloz, 1998

Yvonne Lambert-Faivre, Droit des assurances, 12 éd., Paris, Dalloz, 2005

\section{2- Ouvrages speciaux et theses}

1-Beira Ehi Marc, Les Assurances Cumulatives, These, Universite De Nice- Faculte De Droitet Dessciences Economiques, 198686

2-Camila HABOUBI, Le secret en droit des assurances, Thèse, UniversitéJean Moulin Lyon 3 , École doctorale : Droit ,2009

3- Christianne Dubreuil , L'assurance: un contrat de bonne foi A 1'6tape de la formation et de l'ex cution, McGill Law Journal 1992

4-C. Mouly, Les causes d'extinction du cautionnement, Université de Montpellier I, 1977.

5-Eloïse Haddad, Les notions de contrat d'assurance, THÈSE, UNIVERSITE PARIS I PANTHÉON SORBONNE, Ecole de droit la Sorbonne,2017.

6-Fulbert Youssouf . Les obligation de l'assuré en matiere d'assurances dommages ,Universite d'Abomey-Calavi(Benin) master droit des affaires et fiscalité 2003

7-Henriette E. KAMENI KEMADJOU, La bonne foi dans le contrat d'assurance, Université de Douala. Master II Recherche 2008

8- J. BONNARD, Droit et pratique des assurances, DELMAS, 1re éd. Paris, 1997

9- J. KULLMANN, LAMY Assurances, édicté par LAMY S.A, 2005

10-J. KULLMANN et al. Lamy assurances, Paris, 2008

11-L. Mayaux, Le temps et l'évolution du risque, colloque AIDA Le facteur "temps" dans l'assuranc, RGDA 2002

12-M. B. CRESCENZO-D'AURIAC, Devoir d'information et de conseil en matière d'assurance, J- Cl., Civ., Fasc. 6, 2005

13-Mme FABRE-MAHNAN, De l'obligation d'information dans les contrats. Essai d'une théorie : LGDJ 1992

14- PATRICE FIL. L'obligation d'information et de conseil en matière d'assurance, presses universitaires d'Aix-Marseille, 1996.

15-Robert W.Emerson, insurance Claims Fraud Problems and Remedies, University of 
Miami Law School, Institutional Repositor y,3/1/1992 .

16-Sameh Borji. Une analyse économique et expérimentale de la fraude à l'assurance et de l'audit. Economies et finances,THESE. Université Panthéon-Sorbonne - Paris I, 2006.

17-Vincent Caron . L'obligation de divulgation et le risque moral en assurance de dommages, Maître en droit de la Faculté de droit de l'Université Laval.2008.

18-www.scribd.com.(Khlifi-Taghzouti-Ichraq,Rifai Ali et G'riguaa Nassim, La bonne foi dans le contrat d'assuranc Faculté des Sciences Juridiques Economiques et Sociales de Fés, Master Droits des Transports )

\section{ثالثا : المراجع باللغة الانجليزية}

1-Karen Ann Gill, Insurance fraud, causes, characteristics and prevention, a thesis for the degree of Doctor University of Leicester, September 2001

2-Yiqing Yang, The Past and Future of Utmost Good Faith: A Comparative Study Between English and Chinese Insurance Law Submitted, a thesis for the degree of Doctor, University of Exeter, December 2017 


\section{فهرس الموضوعات}

$\mid r \varepsilon \wedge$ موجز البحث

1 rol تمهيد

Irov المبحث الأول : حسن نية المؤمن له ..

Irov المطلب الأول : حسن نية المؤمن له في مرحلة المفاوضات ...

IrAN. المطلب الثاني : حسن نية المؤمن له وقت تنفيذ العقد ...

$1 \leqslant Y$. المبحث الثاني : حسن نية المؤمن ( شركة التأمين) .

$\mid\{Y \mid$ المطلب الأول : حسن نية المؤمن في مرحلة المفاوضات

I I المطلب الثاني : حسن نية المؤمن عند إبرام العقد ..

$1 \leqslant \varepsilon 0$ المطلب الثالث : حسن نية المؤمن في تنفيذ عقد التأمين ..

المبحث الثالث : حسن النية كوسيلة للحفاظ على التوازن المالي لعقد التأمين ....... المطلب الأول : التوازن المالي في عقد التأمين الناشئ عن افتراض حسن النية......... الفرع الأول : التوازن الأساسي عند إبرام عقد التأمين ..................................... الفرع الثاني : التوازن المالي أثناء تنفيذ عقد التأمين ..........................................

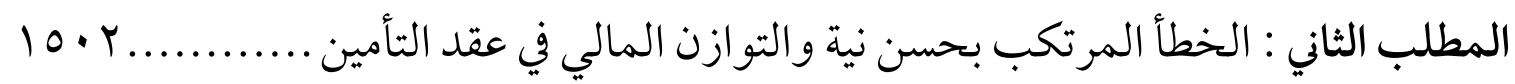
الفرع الأول : تصحيح التوازن المالي في حالة الكشف عن خطأ غير مقصود تم اكتشافه $10 \cdot r$ قبل المطالبة الفرع الثاني : استعادة التوازن المالي للعقد في حال اكتشاف خطأ غير مقصود بعد وقوع $101 \%$ الكارثة. .... lor. خاتمة البحث . Iorr قائمة المراجع. lork فهرس الموضوعات 